Collede Symposium 


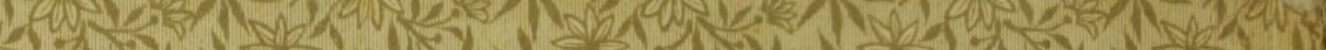










\title{
COLLEGE SYMPOSIUM
}

\author{
OF THE \\ Kansas State Agricultural College.
}

CONTAINING A COMPLETE AND AUTHENTIC HISTORY OF THE INSTITUTION AND ITS VARIOUS DEPARTMENTS; SHORT SKETCHES OF THE FACULTY AXD GRADUATES; ACCOUNTS OF ALL STUDENT ORGANIZATIONS; EXTRACTS FROM SOCIETY PAPERS, STUDENT ORATIONS, ETC.

\section{ILLUSTRATED.}

PREPARED BY THE

COLLEGE SYMPOSIUM PUBLISHING CO., Manhattan, Kansas.

TOPEKA, KANSAS: THE HALI \& O'DONALD IITHO, CO. 1891. 
WE RESPECTFULLY DEDICATE

THIS LITTLE VOLUME

TO ALL WHO, BY THEIR HEARTY CO-OPERATION, HAVE RENDERED

its PUBLICATION A POSSIBILITY. 



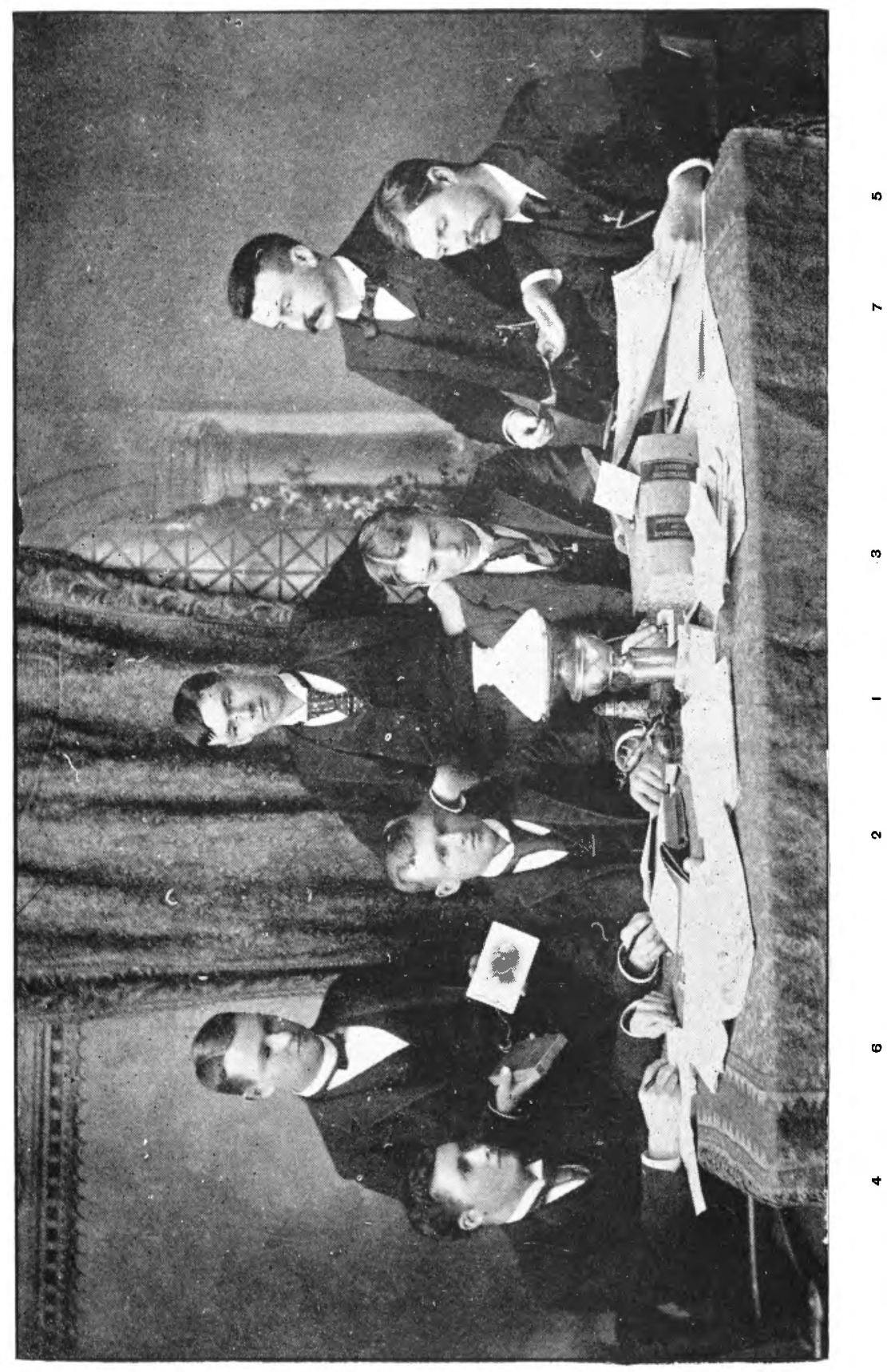




\section{EDITING BOARD.}

1. PHIL S. CREAGER,

EdToR-IN-ChIEF.

2. JOHN O. MORSE,

3. HERMAN W. AVERY,

Literary EdTors.

4. ALFRED MIDGLEY,

Historicat Editor.

5. SAMUEL L. VAN BLARCOM,

Statistical Editor.

6. HALRY E. MOORE,

ART Editor.

7. KARY C. DAVIS,

Business Manager. 


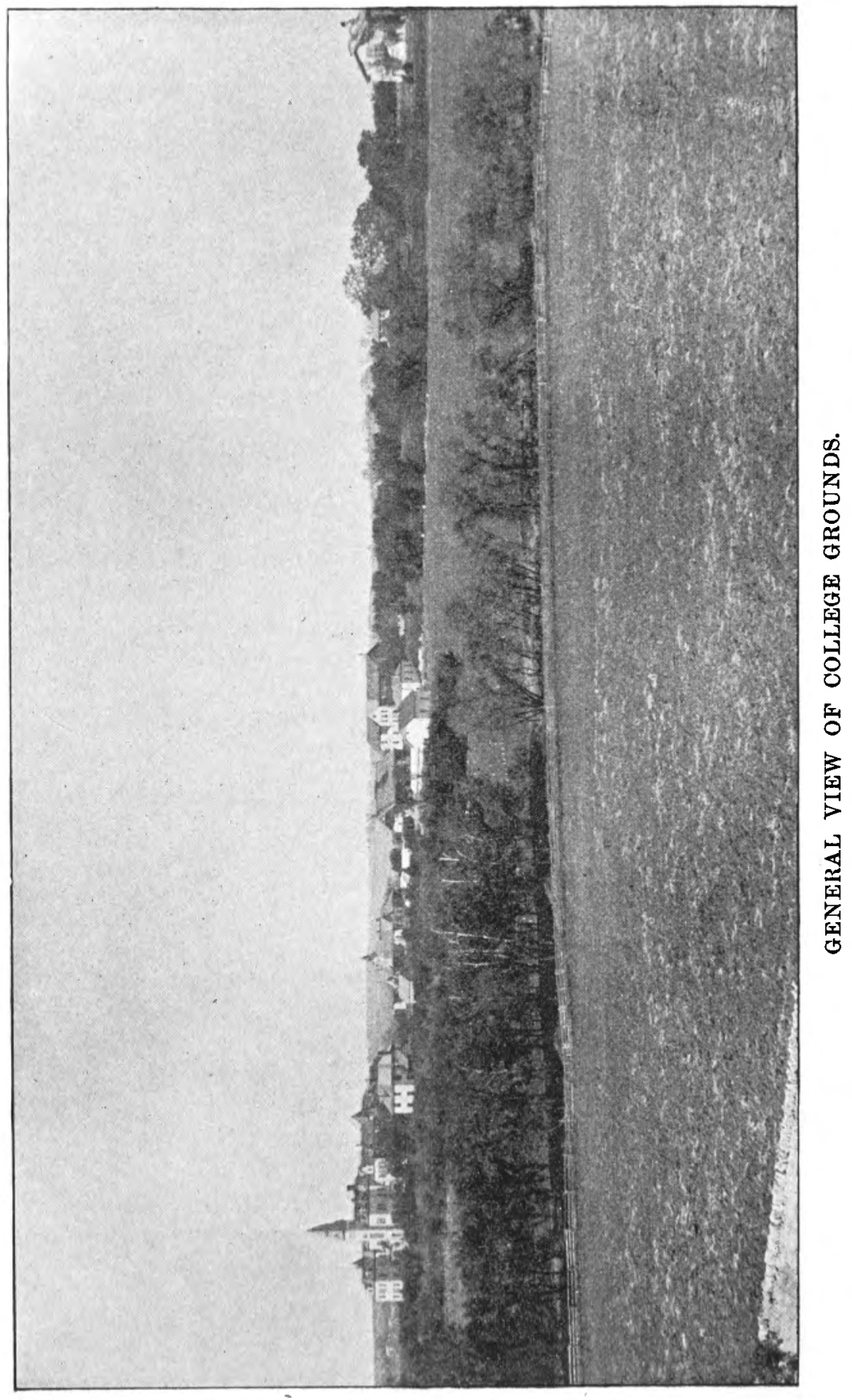




\section{PREFACE.}

Although the Kansas State Agricultural College has been in active operation for nearly a quarter of a century, its students have not heretofore attempted to follow the example set by their eastern contemporaries in the publication of a "college annual," or kindred work. But the increasing number of students and the growing importance of this College as an educational institution has led seven members of the senior class to attempt the publication of a book, which, for lack of a better name, they have called The College Symposium.

We have labored under many disadvantages. The idea of preparing such a book, was not conceived until late in the college year, consequently our work has all been done in great haste, and you will doubtless find in it many imperfecticns, for which we beg charitable consideration. We have done our best, and hope that we have succeeded in compiling something that will be of interest and value to all of our subscribers.

We are indebted to various members of the faculty for valuable assistance, and especially to Prof. J. D. Walters, who has furnished us with the college history, and who has given us great assistance in the work of designing and executing our drawings. We also acknowledge indebtedness to the faculty committee charged with the tedious task of correcting copy and reading proof. To these and the many others who have materially aided us in our labors, we extend our heartfelt thanks.

JuNE $3,1891$.

The Publishers. 


\section{BOARD OF REGEN'TS.}

Hon. Morgan CARAWAY, (1892,)* President.

Great Bend, Barton Co.

Hon. R. W. FINLEY, (1893,) Vice President,

Goodland, Sherman Co.

HoN. JNO. E. HESSIN, (1892,) Treasurer,

Manitattan, Riley Co.

HoN. T. P. MOORE, (1803, Loan Commissioner,

Holton, Jackson Co.

Hon. A. P. Folisy'Th, (1894,) Limenty, Montgonery Co.

Hon. JoshuA WheELER. (1894,) Nortonvir.te, JefFerson Co.

Pres. Geo. T. FAIRChild, (ex officio), Secretary.

I. D. GRAHAM, Assistrnt Secretary. Manhattan.

*'Term expires. 


\section{MANHATTAN.}

Location has very much to do with the success of an educational institution. The conditions that insure good bealth and afford pleasure to the student, as well as to the professor, are potent factors in the upbuilding of a school.

Manhattan was wisely chosen among the many tempting locations offered to the settlers of Kansas "in the fifties," and the selection of a college site in this vicinity, on the choicest of its numerous hills, was the work of wise builders. The winding Kaw, that flows in from the northwest, through many a mile of tortuous and treelined course, met at its most abrupt turns by precipitous bluffs, grass-clad and beautiful in summer, sere and solemn in the autumn; gathering into its bosom the waters of the Blue, which rolls in rapid current down the beautiful valley from Nebraska, our neighbor on the north; thence departing eastward through a broad and fertile plain, leaving a band of brightness in its path that narrows to nothing in the distance; these are the main features of the landscape that spreads out before the student or the visitor as he stands on the college campus, or as he looks outfrom the main building.

Manhattan is one of the choicest spots in Kansas, and not one surpasses it in the elements of beauty that go to make up the surroundings of hill and stream, of wood and road and valley. The combinations that make favorable conditions for health are found here in large degree; but this is not all. Looking across the valley southeasterly from the college Manhattan lies in full view just at the base of the hill on which are grouped the college buildings. Manhattan, a city of pleasant homes, where a full dozen churches rear their spires heavenward, or summon to Sunday service by many pealing bells.

Out from the midst of the city the railroads run in five diverging lines, like the spokes of a wheel. These afford easy access to the hundreds of students and their friends who gather annually at the Kansas State Agricultural College which is to them "a thing of beauty and a joy forever."

"All roads lead to Manhattan." 


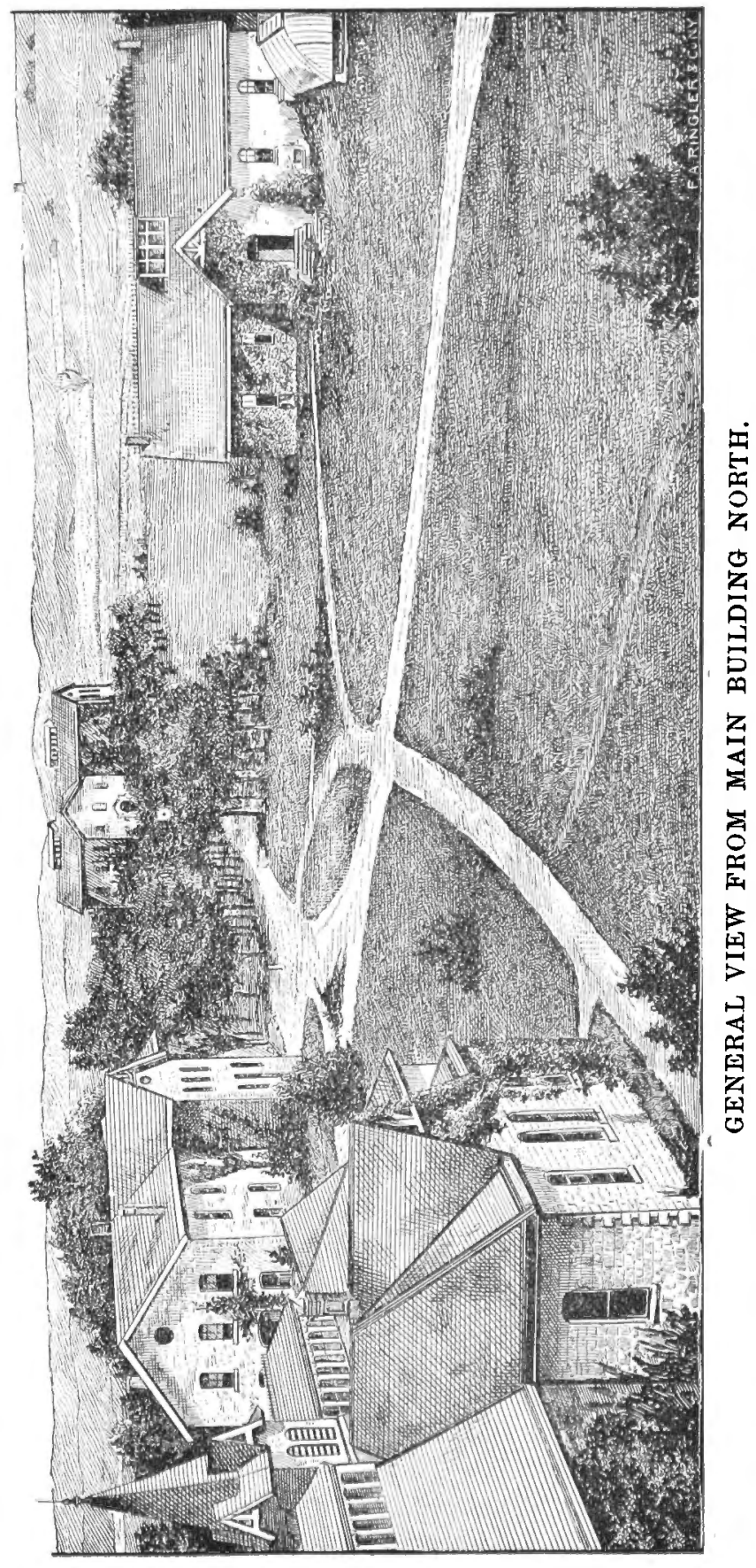




\section{THE KANSAS STATE AGRICULTURAL COLLEGE.}

ITS HISTORY, ENDOWMENT AND OBJECTS.

BY PROF. J. D. WALTERS.

The Kansas State Agricultural College owes its location and initiative momentum to the pioneers of Manbattan, who, unlike the first settlers of many western towns, were mostly people of education and culture. The city was founded in 1855 by the co-operation of two colonies - one from New England, arriving March 24th, and one from Cincinnati, arriving June 1st. Among the members of the New England colony were several college graduates, and it is stated that the founding of a college was discussed and decided upon during the voyage long before reaching the objective point of the expedition, the confluence of the Big Blue and Kaw Rivers.

\section{BLUEMONT COLLEGE.}

From necessity the project bad to be deferred for a while, but it was not abandoned. As early as 1857 , when the buffaloes were yet numerous in the northern part of Riley county, and less than three summers had bleached the roof of the first house west of the Blue river, an association was formed to build a college in or near Manhattan, to be under control of the Methodist Episcopal Church of Kansas, and to be called "Bluemont Central College."

The charter was approved February 9th, 1858. It provided for the establishment of a classical college, but contained the following, in the light of future history, interesting section:

"The said Association shall have power and authority to establish, in addition to the Literary Department of Arts and Sciences, an Agricultural Department, with separate professors, to test soils, experiment in the raising of crops, the cultivation of trees, etc., 
upon a farm set apart for the purpose, so as to bring out to the utmost practical results the agricultural advantages of Kansas, especially the capabilities of the high prairie lands."

The leacling members of the Association were Rev. Joseph Denison, D. D., afterwards President of the College; Isaac T. Goodnow, elected State Superintendent in 1862, re-elected in 1864; Rev. W. Marlatt, now a model farmer on College Hill; C. S. Pomeroy, after-

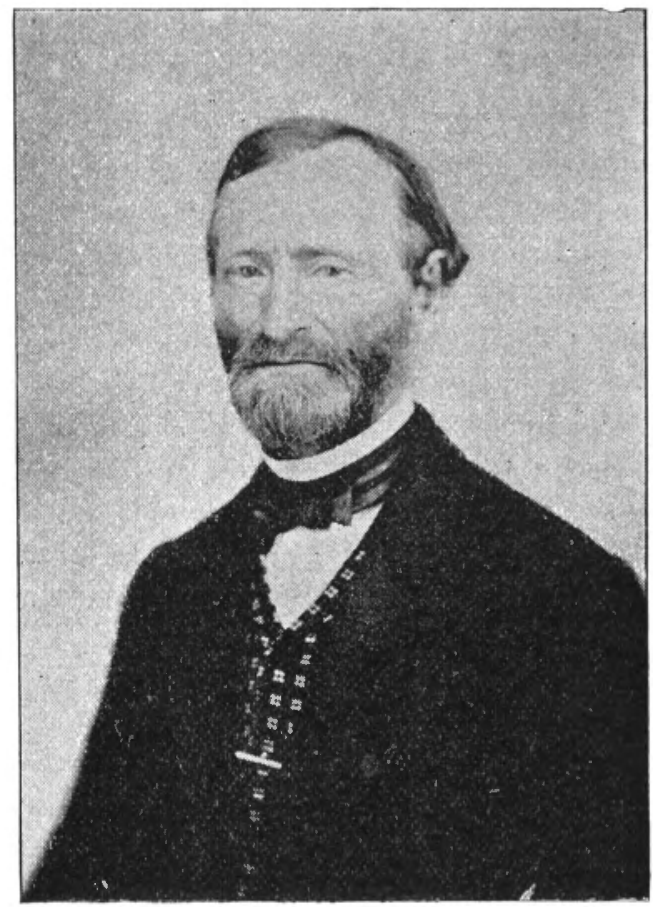

ISAAC T. GOODNOW.

wards U. S. Senator from Kansas; and Geo. S. Park, a Missourian, who had settled just below the mouth of Wild Cat Creek and had laid out a town there some weeks previous to the arrival of the New England colony.

A site of one hundred and sixty acres was selected for the institution upon the rising ground about one mile west from the town, and the title secured by special act of Congress introduced and 
fatbered by Senator Pomeroy. The Cincinnati Town Company promised liberal aid in town lots and town stock, but coupled their promise with the illiberal clause, that the aid should not be delivered until the College Association could show property to the amount of $\$ 100,000$. The New England Town Company gave fifty shares of stock in the north half of Manhattan, representing one hundred city lots. I. T. Goodnow, assisted by Dr. Denison, sold these, and by personal solicitation here and in the East obtained funds for a building. Many of the founders must have taxed themselves quite heavily.

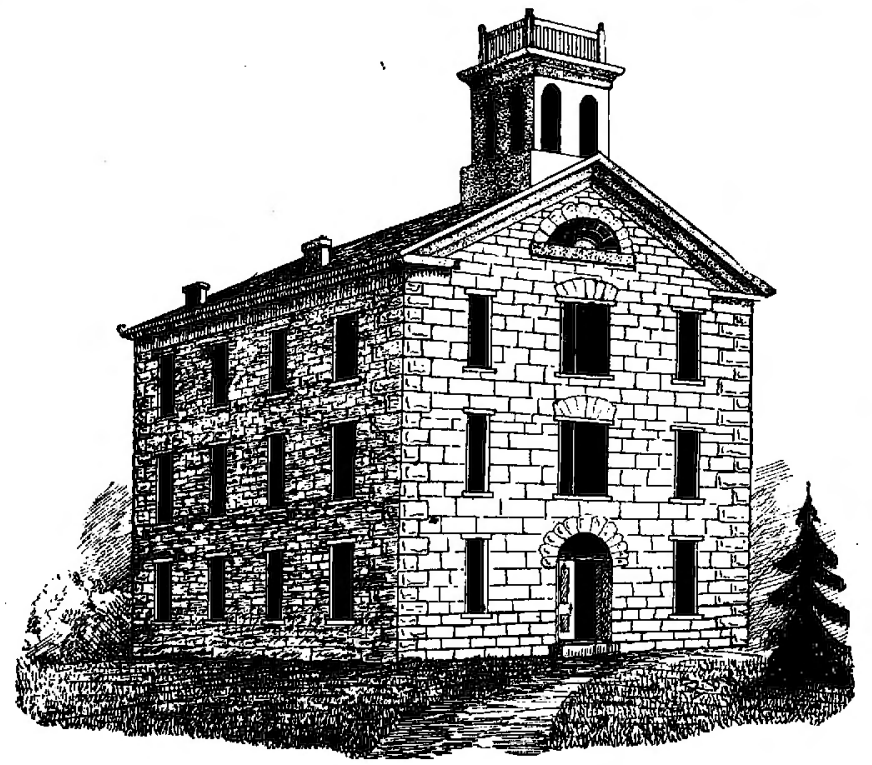

BLUEMOUNT COLLEGE BUILDING.

G. S. Park, S. D. Houston, Joseph Denison, John Kimball, J. S. Goodnow, I. T. Goodnow, and Washington Marlatt, gave three hundred dollars each, which were princely gifts when measured by the financial condition of these pioneers. The whole amount of cash collected from all sources at the time amounted to four thousand dollars.

The corner stone was laid with elaborate ceremony, May 10th, 1859, with speeches from Gen. Pomeroy and others, and the institution was opened for the reception of students about one year thereafter. It was a poor time and place, however, for building up a 
college. The squatters had nothing to give, the students were scarce, the M. E. Conference of the State had two other educational institutions to support, and the whole territory was disturbed by the bloody preambles of the War of the Rebellion.

Upon the admission of Kansas as a State, January 29th, 1861, the founding of a State University became a probability, and the Trustees of Bluemont College, represented by Hon. I. T. Goodnow, were nearly successful in locating that institution at Manhattan by offering their building for this purpose. On March 1st the measure passed both Houses of the Legislature, but met with a veto from Gov. Chas. Robinson, who was determined that the State University or the State Capitol should go to Lawrence. A little over a year later, another chance presented itself for the College to become a State institution. When, on July 2d, 1862, the "Agricultural College Act" was passed by Congress, the Trustees offered it once more to the Legislature, and this time the offer, consisting of one hundred acres of land, a plain three-story stone building, a library of several hundred volumes, and some illustrative apparatus, valued altogether at about twenty-five thousand dollars, was accepted.

\section{THE "MORRILL ACT."}

The act referred to is "An Act donating public lands to the several States and Territories which may provide colleges for the benefit of agriculture and the mechanic arts," giving to each State lands to the amount of 30,000 acres for each senator and representative in Congress for "the endowment, support, and maintenance of at least one college" for the benefit of "agriculture and the mechanic arts." The bill originated with Representative Justin S. Morrill, of Vermont, and was passed by Congress in 1859 ; but was vetoed by President James Buchanan under the pressure of the States Rights party. In 1862 the act was again passed, championed once more by the same philanthropist, who was at this time a member of the Senate, and the same pen that wrote the proclamation of emancipation-the death warrant of American slavery-approved it.

\section{THE ENDOWMENT.}

Kansas was among the first of the galaxy of States to accept the proffered endowment. The resolution of the Legislature to "agree 
and obligate itself to comply with all the provisions of said act" was approved by Governor Carney, February 3d, 1863, and the resolution to accept the offer of the Trustees of Bluemont Central College in "fee simple" February 16th of the same year. Thus Manhattan became the seat of the Kansas State Agricultural College.

Three commissioners were immediately appointed by the Governor to select the lands. The grant gave 90,000 acres; but as a portion of the selected tracts supposed to be within the railroad limits counted double, the college received but $82,313.52$ acres. In

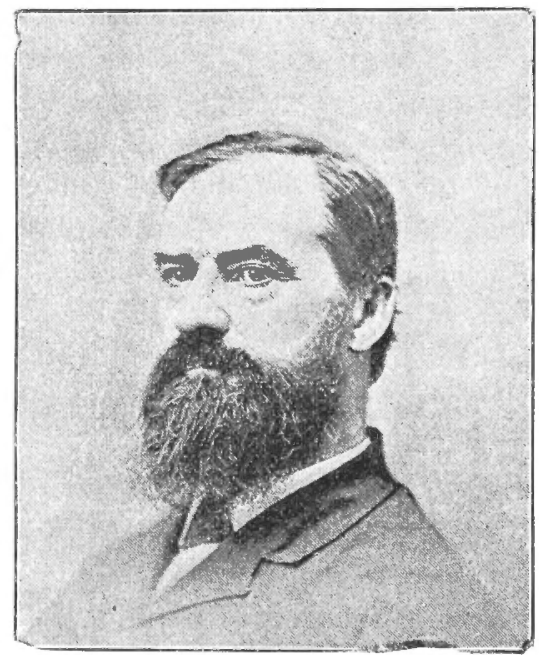

L. R. ELLIOTT.

the fall of 1866, Hon. J. M. Harvey commenced the appraisal of these lands, and July 27th, 1867, reported his work completed. Hon. I. T. Goodnow was appointed land agent in 1867, Hon. S. D. Houston, having, as temporary agent, previously sold a few acres. $\mathrm{Mr}$. Groodnow held the office until the reorganization of the college in 1873 , and sold about 42,000 acres for about $\$ 180,000$. His successor, L. R. Elliott, held the office of land agent from 1873 to 1883, and sold over 32,000 acres for about $\$ 240,000$. The remainder, some 8,000 acres, was sold for over $\$ 30,000$ by Mr. J. B. Gifford, who held the office of land agent until after all the land was sold in 1888. The total fund derived from these sales is $\$ 501,426.33$, all of which, 
except $\$ 13,046.47$ in unpaid land contracts, is invested in Kansas bonds paying six per cent interest. The State has made good losses from this fund by unfortunate investment or fraud to the amount of $\$ 3,775.57$.

The deficiency of $7,686.48$ acres in the amount of land received by the College was closely inquired into, and the still valid claim was presented before the Department of the Interior by Hon. S. J. Crawford, in 1880, and again in 1887, with added proof of its character, afforded by later decisions of the Supreme Court of the United States. When the Secretary of the Interior refused to reopen the case decided adversely in 1880 , the matter was brought to the attention of Congress by a joint resolution offered in the House of Representatives by Hon. John A. Anderson, granting to the State the privilege of selecting from public lands still unsold within the limits of the State the amount needed to make up the loss from the original 90,000 acres. The resolution was favorably reported by the Committee on Public Lands, and passed both Houses without objection. President Cleveland, however, vetoed it upon the ground that this State, having selected lands which fell within the limits of the railroad afterwards located, had received all to which it was rightly entitled.

CONGRESSIONAL APPROPRIATIONS.

In March, 1887, Congress passed the so-called "Hatch Bill," which provided for the organization in each State of a station for agricultural experiments, and gave to each station an annual appropriation of $\$ 15,000$ for this purpose. The Legislature designated this College as the proper place for such experimental work, and the institution has received since April, 1888, when the first payment was made, $\$ 60,000$ from this source. Further particulars with regard to this appropriation, and the very valuable work which it has enabled the College to do in the interest of western agriculture, will be found in another part of this historic sketch.

On August 30th, 1890, another act was passed by Congress, the so-called "College Aid Bill," an a t applying a portion of the proceeds of the public nds to the more complete endowment and support of the colleges for the benefit of agriculture and the mechanic arts established under the provisions of the "Morrill Act." 
It provides for an annual appropriation, beginning with fifteen thousund dollars for 1890 , with an annual increase for ten years by an additional sum of one thousand dollars over the preceding year, the annual amount thereafter to each State to be twenty-five thousand dollars. A provision attached to this bill demands that the appropriation is to be applied only to instruction in agriculture, the mechanic arts, the English language, and the various branches of mathematical, physical, natural and economic science, with special reference to their applications in the industries of life, and to the facilities for such instructions. No money shall be paid out under this act to any State for the support of a college where a distinction of race or color is made in the admission of students, though the establishment and maintenance of such colleges separately for white and colored people shall be held to be a compliance with the provisions of the act, if the funds received be equally divided. Another provision requires that no portion of this appropriation shall be applied, directly or indirectly, under any pretense whatever, to the purchase, erection, preservation or repair of any building or buildings.

\section{STATE APPROPRIATIONS.}

In miscellaneous appropriations, the College has received from the State since its organization, and including the years 1892 and 1893 , for which appropriations have been made, about $\$ 283,000$, and from the township of Manhattan, in $1871, \$ 12,000$ in bonds. These appropriations were made partly for permanent improvements and partly for running expenses or cancelling debts, and do not include pay of Regents, land and loan agents, and for selecting lands. Those of 1868-70 were first made in shape of a loan, but were donated again in 1870. It will be seen that the average annual State appropriation has been less than $\$ 10,000$, while a comparison of the aggregate with the inventory of last year amounting to $\$ 256,249.95$, shows a difference of less than $\$ 20,000$. In other words, the present inventory practically accounts for or compensates for every cent the taxpayers of Kansas have contributed toward the upbuilding of the institution. 


\section{IN 1863.}

It is natural that the College should have remained for a time, as it did, under the care of its founders and donators, and as a conse. quence should have conformed to the ideal before their minds. The charter provided for four departments-science and literature, mechanic arts, agriculture and military tactics. Of these, that of science and literature was put in operation. The course was laid out to cover four years with an indefinite preparatory, and conformed closely with that of Bluemont Central College. The first catalogue gives the names of ninety-four students in the preparatory department and fourteen in the college proper. Seventy-four were from Riley county. The faculty consisted of Rev. Joseph Denison, D. D., A. M., president and professor of ancient languages and mental and moral sciences; J. G. Schnebly, A. M., professor of natural science; Rev. N. O. Preston, A. M., professor of mathematios and English literature; Jeremiah Evarts Platt, principal of preparatory department; Miss Belle Haines, assistant teacher in the preparatory department; and Mrs. Eliza C. Beckwith, teacher of instrumental music.

\section{PRESIDENT DENISON.}

Joseph Denison, D. D., A. M., the first president of the Kansas State Agricultural College, was born in Bernardston, Franklin county, Mass., October 1st, 1815. When he was two years old his parents removed to Colerain, in the same county, where they engaged in farming. Here young Denison lived the usual life of the New England farmer boy of those days. In the fall of 1833 he entered Wilbrakham Academy to prepare for college, and in 1837 he joined the sophomore class in Wesleyan University at Middletown, Conn., where he graduated in 1840. In the same year he was elected Professor of Languages in America Seminary, Duchess county, N. Y., and held that position for three years, having for his pupils such men as Alexander Winchell, the renowned geologist, and Albert S. Hunt, the great philanthropist, whose gifts to hospitals and institutions of learning aggregated a million dollars or more. From 1843 to 1855 he was engaged in the work of the min. istry in Massachusetts, and in the spring of the latter year he came to Kansas, settling on a tract of government land near Manhattan, 


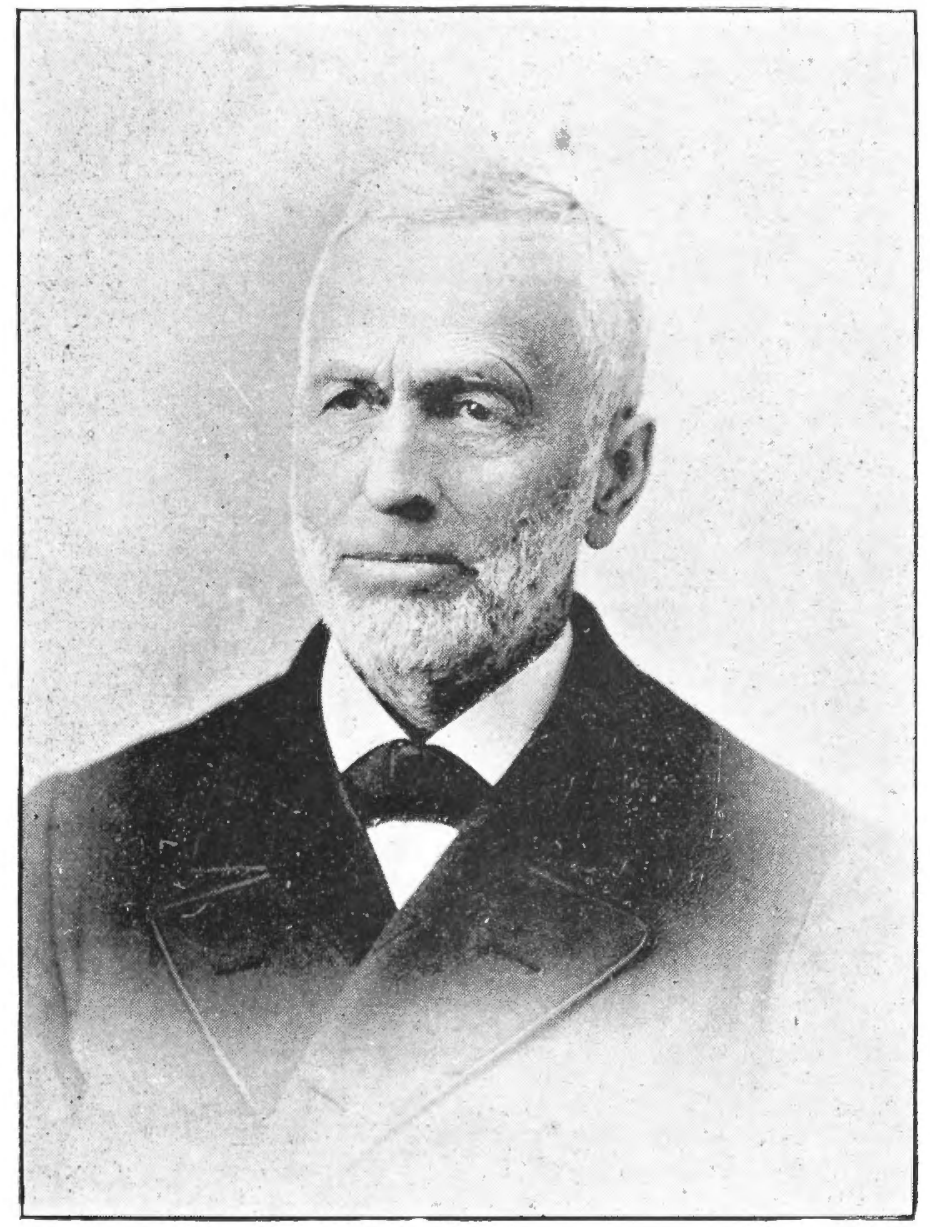

REV. JOSEPH DENISON. 

where he became one of the prime movers in the organization of Bluemont College and its president. A few years later, when the College became a State institution, he was still its president, holding this responsible position until 1873, when he resigned and soon after accepted, for a time, the presidency of Baker University at Baldwin City. At present he is engaged in the work of the ministry of the M. E. Church. Dr. Denison is characterized by his collaborators as a man of conservative views with regard to education, politics and religion--a typical New Englander of the old school. As a financier, for himself as well as for the institution, he did not prove an entire success, but he was warmly devoted to his work, honest to himself and his trust, and unselfish in every one of his acts. Kansas owes Dr. Denison a debt of gratitude which can never be repaid.

\section{FROM 1863 TO 1873.}

During the first ten years, the College grew slowly. Up to 1873 but fifteen students had graduated. The reasons must be looked for in many directions: the newness of the State, the western location of Manhattan, the inadequacy of means, the founding of rival literary institutions at Lawrence, Baldwin, Topeka, etc., and the fact that the industrial education was in its experimental stage. President Denison and a majority of the professors were classic students, and had no faith in the educational results of technical instruction not connected with the classics. They planned to add elective work in practical science and applied mathematics to the "old education," but it should supplement, and not supplant, this. The introduction of obligatory daily manual labor as an educational factor was not attempted. Aside from occasional lectures on general topics, little work was done for agriculture and the mechanic arts, and the increasingly frequent demands for an institution that would educate towards, instead of away from, the farm and the workshop were met with uncertain promises. The Board, largely composed of professional men, must have held similar views, though the report of the State Commissioners of 1873 says that "Attempts were made by members of this body at different times to change the curriculum of study, and in other respects to alter the running of the College so as to make it conform more nearly to the demands of the people." 
It should not be assumed, however, that the institution failed of doing good work in its class rooms. The Literary Department was second to no higher school of the kind in the State. The catalogue of 1868-69 states that, up to that time, the College had educated at least eighty teachers for the public schools. A large number of ministers, especially of the M. E. church, which still considered the institution as its protege, and reported it as such at the annual conferences, also received their education here. Nor were the sciences entirely neglected. Benjamin F. Mudge, A. M., called to the chair of natural science in 1865, was an enthusiastic teacher and an untiring explorer. Aided by some of his pupils, one of whom is now

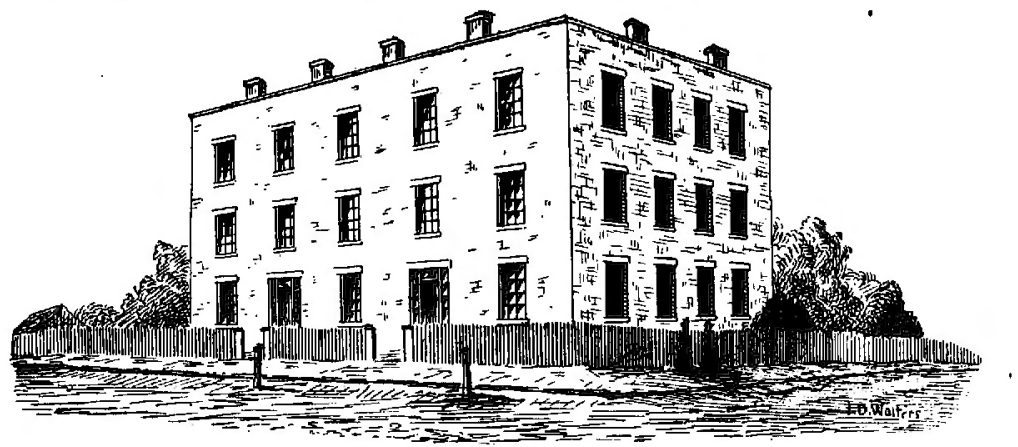

BOARDING HALL.

professor of geology at the Kansas State University, Professor Mudge made a large collection of geological specimens and donated it to the College, where it formed a nucleus of the present museum. Being the first "take" in the new State, it contained many specimens which could not have been acquired later. The professor taught at the College for about eight years, after which he devoted himself entirely to the work of collecting for eastern institutions and the writing of scientific papers for a number of publications. To him the State of Kansas owes its first comprehensive geological map; and it was a proper acknowiedgment of her indebtedness to his unselfish life-work, when after his death in 1879 , his naine was engraved in one of the wall panels in the Hall of Representatives at the State Capitol, and the State Academy of Science erected a massive granite monument upon his grave overlooking the College building from a neighboring hill. 
The following is a short synopsis of the material signs of progress and growth during the period: A library of nearly three thousand volumes was accumulated, chiefly through the efforts of Hon. I. T. Goodnow, who wrote hundreds of soliciting letters to eastern publishers, philanthropists and personal friends. In 1867, a capacious Student Boarding Hall was built by resident parties, but, as it proved a poor financial investment, it was afterwards urged upon and purchased by the College, a deal that evoked severe cen-

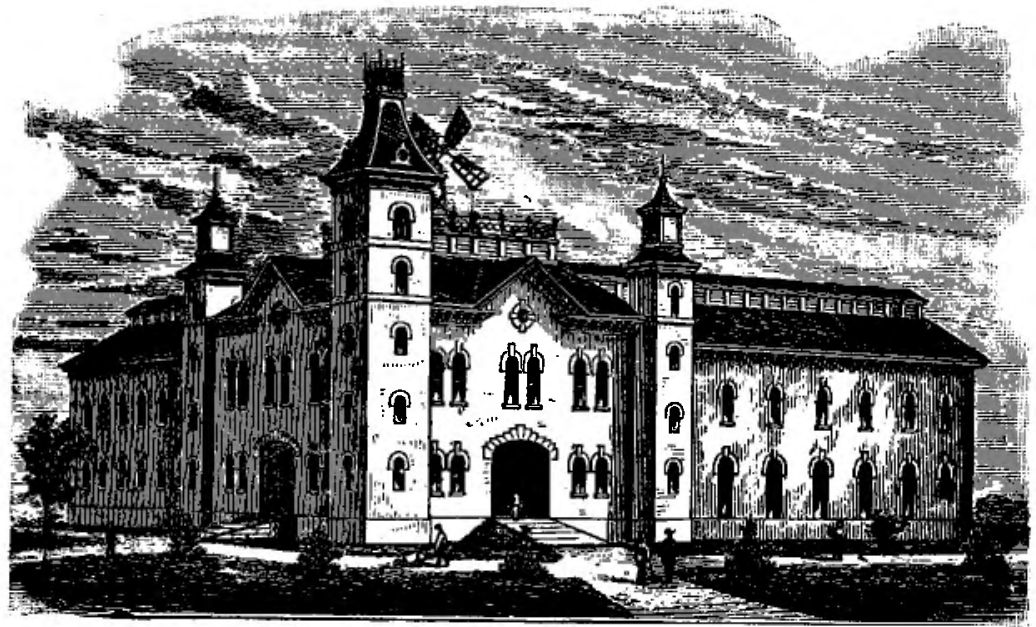

BARN AS IT WAS TO BE.

sure by the people of the State, and furnished a point of attack to unfriendly legislators for a whole decade. At the time of its erection the building met an evident want, but, costing the College over $\$ 10,000$ when this was financially embarrassed, the purchase was a misfortune. In 1875 , when the College was removed to the new farm, the Hall became entirely useless, until, in 1889, after having been sold to a private party for $\$ 1,000$, a fire devoured its rotten floors and roofs and calcined its crumbling walls. In 1868, an extensive forest and fruit tree plantation was started. It contained some two hundred varieties of trees, many of which were entirely new to the prairie country, and have since then proved very valuable. In 1871, the "New Farm," a beautifully-located tract of land, comprising 155 acres, was bought at a total cost of $\$ 29$,832.71, in scrip. The city of Manhattan, frightened over the re- 
peated attempts of realous friends of the StateUniversity at Lawrence to consolidate the Agricultural College with that institution, contributed $\$ 12,000$, the result of a bond election. A solid stone fence was built around the whole tract, and the erection of a large barn commenced - a broad, corniced, massive-looking stone structure, with numerous wings, towers, stairways, elevators and offices. The barn was never completed, however, and the finished west wing served its purpose for a short time only. It was afterwards, under President John A. Anderson, turned into a class room building, and still later, under President Geo. T. Fairchild, into a drill ball and museum. In 1872, a Veterinary Department was organized and put under the management of J. H. Detmers, V. S., but discontinued, in 1874, for want of means and patronage.

\section{THE REORGANIZATION.}

In accordance with an act of the Legislature reconstructing the governments of the several State institutions, approved March 6th, 1873 , Governor Osborne in the spring of that year appointed a new Board. Soon afterwards President Denison resigned, and the vacancy was filled by the election of Rev. John A. Anderson of Junction City. The result was a radical change in the policy of the institution. To this Board, counting among its members such men as Dr. Charles Reynolds, post chaplain at Fort Riley, and J. K. Hudson, the founder of the Kansas Farmer and the Capital, and to President Anderson, the State is indebted for the conception and inauguration of the educational policy which has placed the Kansas State Agricultural College near the head of the list of the landgrant institutions of America.

\section{JOHN A. ANDERSON.}

John A. Anderson was born in Washington county, Pennsylvania, June 26th, 1834; graduated at Miami University in 1853, the room-mate of President Benjamin Harrison; studied theology, and preached in Stockton, California, from 1857 till 1862. Early in that year he entered the army as chaplain of the Third California Infantry. In 1863, he entered the service of the United States Sanitary Commission, and his first duty was to act as relief agent of the Twelfth Army Corps. He was next transferred to its central 


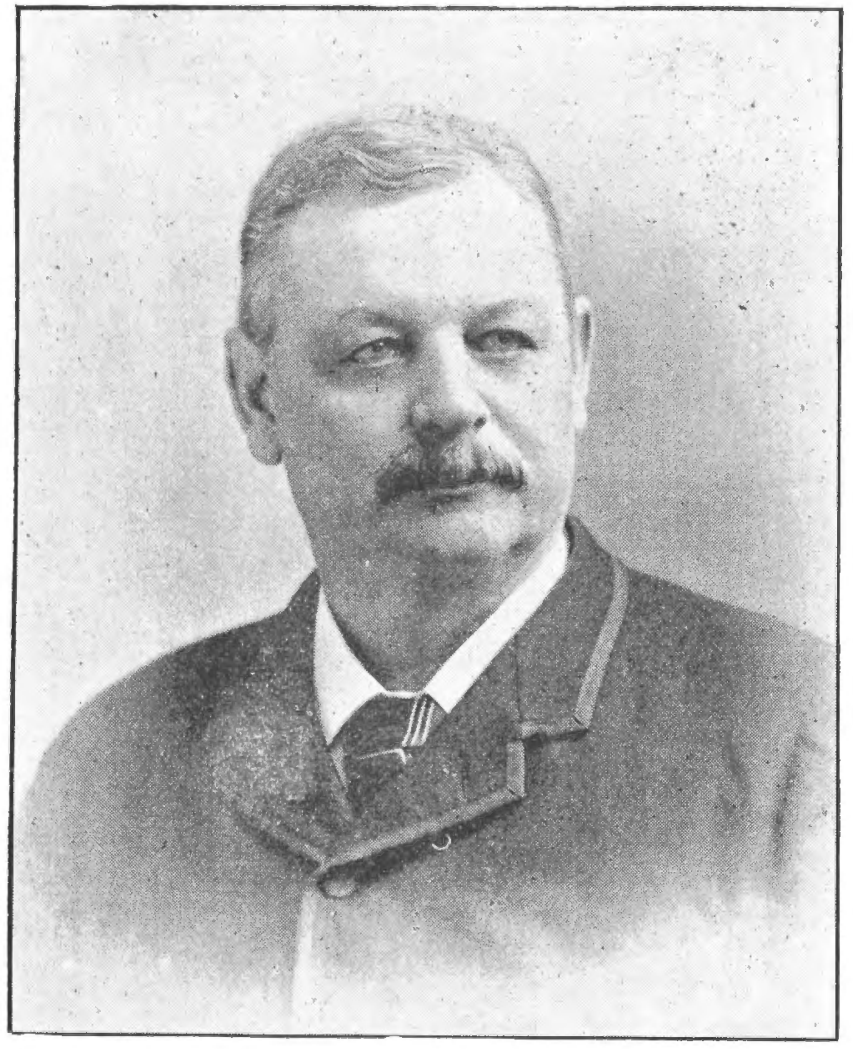

HON. JOHN A. ANDERSON. 

office, in New York. When Grant began the movement through the Wilderness, Anderson was made Superintendent of transportation, and had under his command half a dozen steamers. Upon completion of this campaign, he served as Assistant Superintendent of the Canvass and Supply Department at Philadelphia, and edited a paper called the Sanitary Commission Bulletin. At the close of the war he was transferred to the Historical Bureau of the Commission at $\mathrm{W}$ ashington, remaining there one year, collecting data and writing a portion of the history of the Commission. In 1866, he was appointed Statistician of the Citizens' Association of Pennsylvania, an organization for the purpose of relieving the suffering resulting from pauperism, vagrancy, and crime in the large cities. In February, 1868, he accepted a call from the Presbyterian church at Junction City, Kansas, and remained its pastor until the fall of 1873, when he became president of the Kansas State Agricultural College at Manhattan, which position he held until his election to Congress in 1878. While president of the College he was appointed one of the jurors on machine tools for wood, metal, and stone at the Centennial Exhibition.

The subsequent history of John A. Anderson is equally characteristic of the man. He served as member of Congress from this district until the spring of 1891. During the fall campaign of 1890 the Farmers Alliance movement had withdrawn from the ranks of the Republican party much of the element which had elected and re-elected him triumphantly in six consecutive elections. Anderson was not re-nominated and refused to run "wild." The result was, that the Republican party, as well as its trustworthy leader in this district, lost a seat in Congress. Of the large number of Congressional bills which were introduced and advocated by Anderson may be mentioned the one reducing the postage of letters from three to two cents, and the one creating an agricultural department as a branch of the National executive government. In March, 1891, Anderson was appointed Consul General to Cairo, Egypt, and sailed for his new post on April 6th.

In a "Hand-book of the Kansas State Agricultural College," published in 1874, President Anderson fully discussed his reasons for the changes made in the old system, a few of which are epitomized here :- 
1. It is impossible for most people to find time to study everything that it is important for some men to master.

2. The suljects discarded, in whole or in part, by each separate class of students should be those that it is supposed will be of least importance to them.

3. Of those retained, prominence should be given to each in proportion to the actual benefit expected to be derived from it.

4. The farmer and mechanic should be as completely educated as the lawyer and minister; but the information that is essential to the one class is often comparatively useless to the other; and it is therefore unjust to compel all classes to pursue the same course of study.

5. Ninety-seven per cent of the people of Kansas are in the various industrial vocations, and only three per cent. in the learned professions ; yet prominence is given to the studies that are most useful to the professions instead of those that are most useful to the industrial pursuits. This state of things should be reversed, and the greatest prominence given to the subjects that are the most certain to fit the great majority for the work they should and will pursue.

6. Most young men and young women are unable to go "through" college. Therefore, each year's course of study should, as far as is practicable, be complete in itself.

7. The natural effect of exclusive head-work, as contradistinguished from hand-work, is to beget a dislike for the latter.

8. The only way to counteract this tendency is to educate the head and the hands at the same time, so that when a young man leaves college he will be prepared to earn his living in a vocation in which he has fitted himself to excel.

\section{THE NEW EDUCATION.}

Adopting these views, the Board of Regents discontinued the school of literature and organized those of agriculture and the mechanic arts. Three new professorships were established; namely, botany and entomology, Professor J. S. Whitman ; chemistry and physics, Professor W. K. Kedzie; mathematics, Professor M. L. Ward. In order to provide better accommodations for the students the departments of instruction were removed from the old farm to 
the new one, where the finished wing of the barn was fitted up for class rooms. Work shops in ron and wood, a printing office, a telegraph office, a kitchen laboratory, and a sewing room were equipped and provided with instructors, and fifty minutes of educational manual labor was added to the daily work of every student. Three years later the course of study was reduced to four years; $i$. e. the preparatory course was abolished, the teaching of Butler's analogy, Latin, German and French discontinued, and the requirements for admission lowered so as to connect the institution directly with the better grade of public schools.

In order to fully appreciate the efforts of President Anderson with regard to the reorganization of the work of instruction, it seems necessary to take a glance at the educational reform movement in other parts of the country. It is a fact not generally known, and one of which Kansas and the friends of this institution may well be proud, that the Kansas State Agricultural College was among the very first free schools of college grade in the United States where systematic daily manual work became an obligatory branch of instruction for all male students, and that it was the first institution of any kind in this country which reduced the minimum age of admission to such instruction to fourteen years. There had, of course, been numerous attempts to teach such work before, but it had either been made optional or else it was limited to certain departments. In the Worcester Free Institute, founded in 1865 and opened in November, 1868, the shop work was made obligatory only to the students in the course of mechanical engineering, all of whom were above sixteen years of age. In the Industrial University of Illinois, shop work was provided only for the students in the architectural department. In Washington University, at St. Louis, the Preparatory or Manual Training School, which, through the writings and enthusiastic work of its Dean, C. M. Woodward, has become the pattern for schools of the kind from the Atlantic to the Pacific, and far beyond, and is usually considered as the first institution that provided systematic instruction in wood and iron work to all of its pupils, the first experiments in this line were made in 1872. The work, however, was limited to the polytechnic departments, and the age of admission of the pupils to fifteen years, while the Manual Training School was not organized until June 6th, 1879. 
The Massachusetts Institute of Technology, where the "father of American tool instruction," President J. D. Runkle, developed the analytical system of shop work, an improvement upon the Russian system of Della Vos, did not commence instruction in iron work until the spring of 1877. The only institution, in fact, which gave daily shop instruction to all its pupils, previous to the reconstruction of the Kansas State Agricultural College, was the Stevens Institute of Technology, of Hoboken, N. J., created by the munificence of the great philanthropist, S. A. Stevens. It will be seen from these historic statements of the growth of tool instruction that President Anderson was well forward among the educators of the country who foresaw the coming educational changes; that he was a leader rather than a follower.

As might be expected, these changes of educational policy created some friction. Several members of the old teaching force resigned, while others, taking part against the reorganization, were discharged. Even the newly called members were more or less strongly opposed to some of the methods adopted by Anderson, especially with regard to the reduction of the course of study from six to four years, and the abolishing of the instruction in Latin. The most intense feeling existed for a while. The students, encouraged by the attitude of the retiring professors, held indignation meetings, while the citizens of Manhattan, considering the fight largely their own, were split into irreconcilable factions-"for Latin" and "against Latin." Petitions were sent to the Board requesting a change of policy in order to save the institution from certain ruin. The aid of the Governor was evoked to remove President Anderson, who was described as an educational charlatan; but the management remained firm. Gradually the storm subsided. The new members of the faculty began to assert their influence; the attendance did not fall off as had been predicted, the Legislature was satisfied with the change; and the "new education," though hardly more than an experiment as yet, had scored another victory.

\section{"THE INDUSTRIALIST,"}

President Anderson was a prolific and vigorous writer. $\mathrm{He}$ defended his policy whenever and wherever he was attacked, and gave no quarter. His chief weapon during these struggles was the 



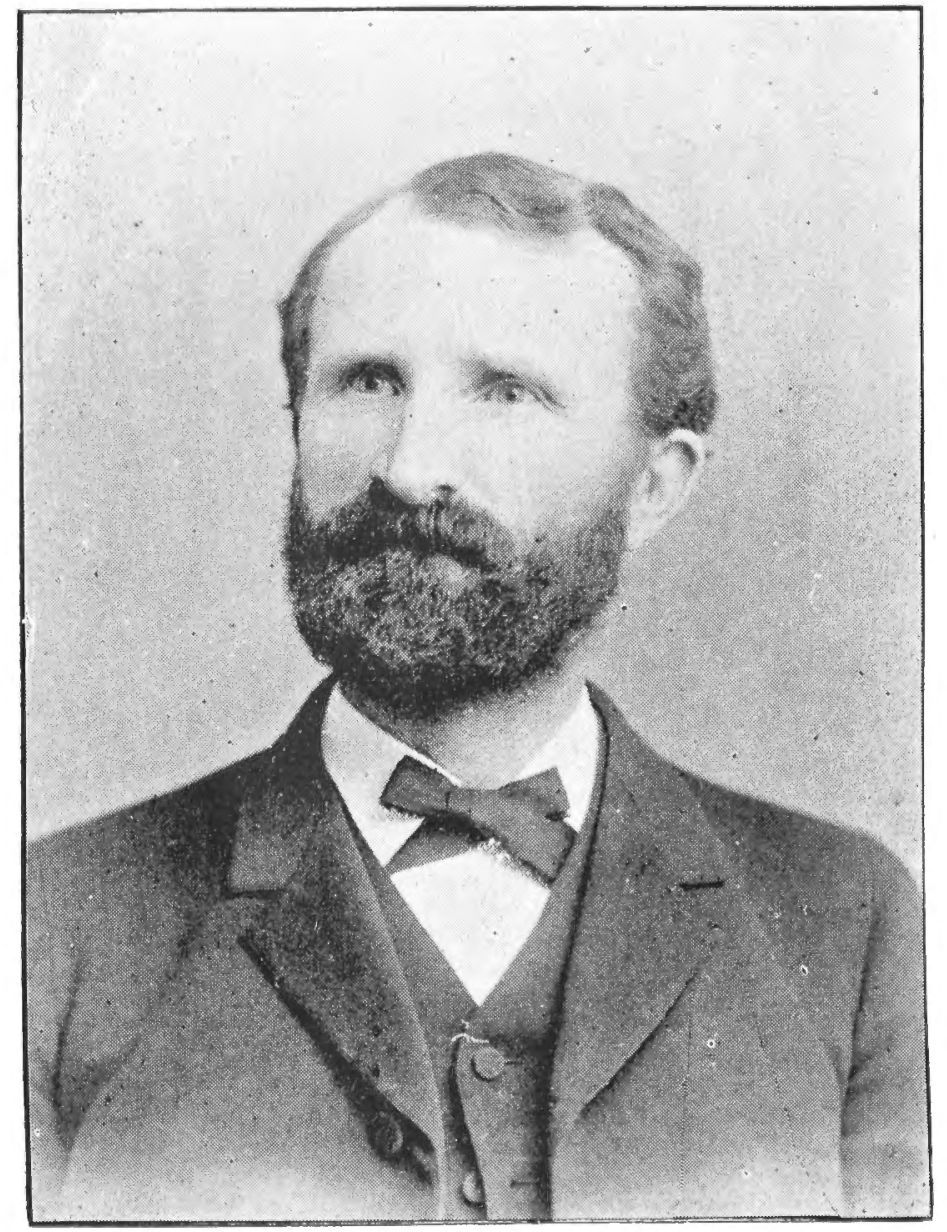

PROF. E. M. SHELTON. 
Weekly Industrialist, edited by the faculty, and printed by the printing department. The first number appeared on April 24,1875, and the paper has been issued ever since--an effective advertiser of the College and its work, and a ready medium for the dissemination of experimental knowledge, new pedagogical theories, and scientific truths. The Industrialist is now completing its sixteenth volume.

PRESIDENT ANDERSON'S COLLABORATORS.

Among the new members of the faculty none entered upon the work of reorganization with more zeal and sympathy and assisted more effectively in bringing its practical work into favor with the farmers of the State, than Prof. E. M. Shelton, M. Sc., elected to the Chair of Agriculture in 1874.

Edward Mason Shelton was born in Huntingdonshire, England, August 7th, 1846, and in 1855 , came with his parents to America, settling in New York. In 1860, the family moved to Michigan. He received his education at the Michigan Agricultural College, graduating in 1871 , and took a course of special study under Dr. Manly Miles. At this time an agent of the Japanese government was in this country, seeking men for the advancement of the agricultural interests of Japan, and through him Mr. Shelton was appointed Superintendent of the Government Experiment Farm at Tokio. He was the first teacher of American agricultural methods and systematic farming in Japan, and although ill health demanded his return to America at the expiration of a year, he left a strong impression upon the farming interests of that country. He next joined the Greeley Colony of Colorado, but soon returned to his agricultural studies and investigations at the Michigan College, and from thence was in 1874 chosen Professor of Agriculture and Superintendent of the Farm at the Kansas State Agricultural College, in which position he remained until the first of January, 1890, when be accepted a call by the Governor of Queensland, Australia, to the honorable and responsible position of agricultural adviser to the government. His writings have been widely quoted, and his influence has been marked upon the trend of agricultural education. He was secretary of the State Shorthorn Breeders' Association and of the National Association for the advancement of Agricultural Science. 
Of other teachers who were elected during the presidency of Anderson, and are entitled to credit for assistance in the work of reconstruction, should be named Professors William K. Kedzie, M. Sc., M. L. Ward, A. M., George H. Failyer, M. Sc., and John D. Walters, M. Sc. Biographical sketches of the two last named who have remained with the College, will be found in another part of this volume.

Prof. W.K. Kedzie was the eldest son of the veteran teacher of agricultural chemistry at the Michigan Agricultural College, Prof. R. C. Kedzie. He graduated at that institution in 1870 , took a special course at the Sheffield Scientific School of Yale College, and became assistant to his father at Lansing, Mich., until his call to Manhattan in 1873. Coming to the Agricultural College of Kansas at the time of its reorganization, he lent valuable assistance in shaping the course of instruction and giving the branches of chemistry, mineralogy, geology, and meteorology the prominent position which they deserve in the curriculum of such an institution. While here he wrote a small text-book, "The Geology of Kansas." In 1878 he accepted a call to Oberlin College, Ohio, and died in 1880 , in the prime of his life.

Prof. M. L. Ward was brought up on a farm without early opportunities in school, but graduated from Hamilton Collegre, N. Y., and afterward was ordained to the ministry in the Baptist church. For some years he, with the assistance of Mrs. Ward, maintained a successful private school at Ottawa, Kansas, and from that was called, in 1873, to the chair of mathematics in this College. In this position, with many fluctuations of duties, he did faithful, energetic work for ten years, and often helped to hold together conflicting forces in the faculty by combining earnest regard for the practical side of the new plans with an abiding faith in mental discipline as the foundation of all true education. It was not strange that he was made acting president during President Anderson's campaign for Congressman, or that after leaving this College in 1883, he should be called to the Presidency of Ottawa University, where he still remains as a member of the faculty.

FROM 1873 TO 1878.

Of permanent improvements during Mr. Anderson's presidency, may be enumerated the building, in 1875, of Mechanics' Hall, and in 
the year following of Horticultural Hall and the Chemical Laboratory-the last after sketches by Prof. William K. Kedzie, who, at his own expense, had visited Central Europe and the East to study the arrangement and furnishing of chemical workshops. In 1877 the main part of the present barn was constructed after directions by Prof. E. M. Shelton. The corner stone of the north wing of the Main College Hall was laid in 1878, and this part of the building completed in February, 1879.

In the summer of 1878, President Anderson was urged by leading Republicans of the (then) First Congressional District to become the candidate of the party for United States Representative. He accepted the honor, feeling that the work at the College requiring his peculiar bent of character, and which, perhaps, but few could have performed, was done. The institution was safe from reaction with regard to its course of study, secure from absorption by the State University, and past the threatening spectre of tinancial ruin. It had no name as yetamong the institutions of learning of the land; its attendance was small, its library insignificant, and its apparatus lacked much that was absolutely necessary; but it had found its distinct sphere of usefulness. The debt, which in 1873 had amounted to over $\$ 42,000$, was reduced to $\$ 18,000$. endowment and $\$ 6,000$ current expense fund. The productive endowment had grown to about $\$ 240,000$, and the annual income amounted to nearly $\$ 20,000$. Yet his election to Congress in November, 1878, and consequent resignation in August, placed the Board in a perplexing situation. It seemed almost impossible to find a man whose previous work and training would furnish a guarantee for success. There were plenty of candidates, indeed it seemed as if every defunct county superintendent or worn out preacher in the State believed himself exactly the man to pilot the newly-rigged vessel

"Through squalls and storms, O'er rocks and riffs."

But no agreement could be reached until the following September, when a member of the faculty suggested his former teacher, Prof. Geo. T. Fairchild, of Michigan Agricultural College, as a suitable man. Professor Fairchild was "called," came to Manhattan to make a personal examination of the condition of the College, and accepted the responsible position. 


\section{IN 1878 AND 1879.}

Before entering upon a discussion of President Fairchild's aims and efforts, it seems proper to say a few words of the history of the period intervening between his election and the resignation of President Anderson.

From February to December, 1879 , and to some extent from the time of Anderson's nomination for U.S. Representative, the executive work of the College was faithfully performed by the acting president, Prof. M. L. Ward, but the result of long delay in electing a president had begun to exhibit itself in many directions, the more so because changes had been made in two of the chairs during the summer. The faculty were underpaid and overworked. The Legislature of 1877 had decreed "that not over $\$ 15,000$ of the interest on the endowment fund shall be used to pay instructors or teachers in said College, until the debts of said College be paid in full, and until said College shall refund to the State all moneys advanced by the State to pay for instructors and running expenses of said College." In accordance with this " ukase," the salaries of the majority of the members of the faculty had been reduced, in some cases as much as four hundred dollars, while the work was constantly increasing in all directions. In his Department Report for "78-79, Prof. Ward said: "In the discharge of my duties as a Professor, I will simply say that I have done as best I could under the circumstances," and a prominent friend of the institution wrote: "It was a year of drudgery and heroic devotion to the cause and to the College for which the acting president and his collaborators received neither proper credit on the part of a wrangling Board, nor proper pay on the part of a rich State."

\section{PRESIDENT FAIRCHILD.}

President George Thompson Fairchild, A. M., was born in Brownhelm, Lorain county, Ohio, October 6th, 1838. His father was a farmer and teacher. There were four sons and four daughters, of whom George T. was the youngest. He was educated at Oberlin College, graduated in the classical course in 1862, and in the Department of Theology in 1865, and though never a pastor, was afterwards ordained to the ministry of the Congregational church. In the same year he was elected instructor in the Michigan Agricul- 


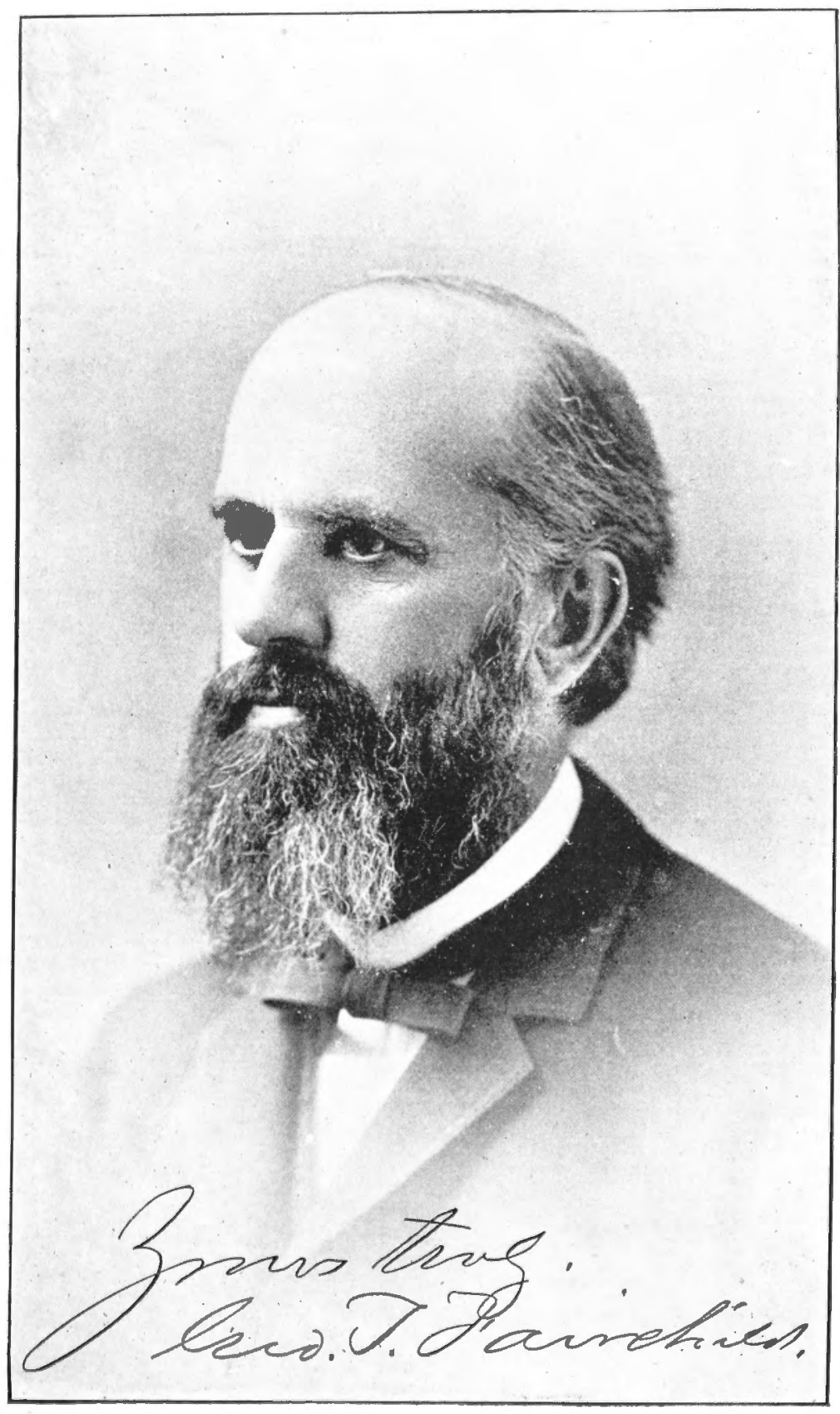



tural College, and the next year was made Professor of English Literature, which chair he filled until his call to the presidency of the Kansas State Agricultural College, where he entered upon his work December 1st, 1879. President Fairchild is a prominent member of the National Educational Association, and has contributed several valuable papers to the published proceedings of that body. At the session at Saratoga, N. Y., in 1885, he was made a member of the National Council of Education and appointed to the Committee of Technological Education. At the meeting in Chicago, in 1887, he was made president of the Industrial Section, and in the following year, at San Francisco, he was re-elected to the same position. In 1886, the faculty of the Kansas State Agricultural College, in order to show him their appreciation of his work and to give him a fitting token of their esteem, presented him with a life directorship in the National Educational Association. In the American Association of Agricultural Colleges he has twice held the office of vice president and his services on important committees have had their directing effect upon that organization. One of his brothers, James H. Fairchild, was for many years president of Oberlin College, and another brother, E. H. Fairchild, president of Berea College, Kentucky.

President Fairchild's views, with regard to the "new education," were not as radical as those of Anderson had been. With President Anderson the Agricultural College had been largely a station for pedagogical experiments conducted with the view of producing convincing proofs of his theories on the value of manual training. With President Fairchild the College became a model school for the education of young men and women who were to go back to the farm or workshop, not only to perform manual labor, but to live complete lives and to develop and honor their calling. In an article on "Our Agricultural Colleges," written for the Chicago F'armers' Reviero, and subsequently published by the Michigan State Board of Agriculture in their annual report, President Fairchild, then professor at the Michigan State Agricultural Coli lege, presented his ideal in such a characteristic manner that there could be no doubt in the minds of those who called him to Kansas as to his aims and methods. Other articles and papers published during the'last dozen years, and especially one on "Agricultural 
Schools: Their Aims, Objects, Methods and Equipments," read before the council of the National Educational Association in 1888, show that his subsequent experience as the bead of the Kansas institution but corroborated the views of the teacher in the Michigan college. The following is a synopsis of the Review article:

\section{THE IDEAL.}

"In a brief notice of what our agricultural colleges ought to be, it may properly be assumed that they ought to be, first, what the name college implies every where now-places for the education of the young. Whatever service they may render in affording models for farming for the public, or in searching for new facts, principles or applications in agriculture must be secondary. The education which they furnish must be agricultural, in quickening and deepening a young man's regard for a farmer's life, while in every way making bim more capable in such a life. Learning and labor are to meet in a more profitable life upon the soil. With this understanding, it may be well to consider more specifically

\section{THE AIMS.}

"Of these there are two classes, closely united: to develop the man in the farmer, and to develop farming through the man engaged in it. The first is to be sought in discipline, the genuine education of the youth. True scientific principles, which underlie all knowledge, are to be taught and enforced by a thorough drill in observation. The eyes must see and the hands handle the very elements of nature, in order to gain proper ideas of nature's use. There must be a definite training to think accurately and connectedly, and intensely if need be. Thinking has made the world's discoveries and inventions, and it will always be the means of progress in any calling. Thinking to a purpose will always distinguish the able man and the efficient work, and our College will have missed its aim if it fails to furnish thorough training to think. Added to this must be the formation of habits of ready action to a purpose. The thinking and doing are so closely united in farming that no one can neglect training in both. Often the only expression of the thought is the act that turns soil and seed, sunshine and shower, into produce. The College must aim at such a combination of thought and action 
in its goutine of drill for developing the best men for the work of making farming better.

"The second is to be sought through information. While this always accompanies discipline and directs the application of ability, it differs from that just as the instruction of a child how to drive a nail differs from the training which enables him to do it successfully. The College must gather and impart the best of instructions in the art of tilling the soil. It must gather from the history of this art, and from the failures and successes of practice and experiment, constantly, such facts as will make the strongest impression. By such means it aims to give higher ideals and stronger ambition to do excellent work. It stimulates discussion and comparison of experiences, and encourages thoughtful consideration of future prospects. It aims to be a center of information for a farming community through its instruction to learners. So far as is compatible with thorough discipline and accurate information, it aims to be a leader in further improvement of practice by new devices, but consciously preserves the difference between knowledge and supposition, fact and theory. Such aims suggest

\section{THE METHODS.}

"Most prominent must stand a thorough course of study, long enough to establish principles and habits, severe enough to develop strength of mind, and so associated with agriculture as to cultivate enthusiasm for it. In this there must be systematic instruction by most approved methods in the sciences, training to logical investigation of facts and principles, history and general knowledge of civilization enough to kindle inquiry, and technical training enough to give a general ability.

"This involves a drill in manual labor that shall make the hands ready and the eyes quick. That dexterity which comes from long practice in one routine is not desirable at this stage of education, if it were practicable; but a readiness to turn the hand to account in various directions is to be provided for by regular duty in real work, where pay and reputation and responsibility are thought of, and business rules apply, while a zest is given by connection with study and thought under competent oversight. These methods would bear a lengthy study, but we must hasten to connect with them 
THE MEANS.

"Among these we may place first a permanent endowment suffcient to ensure the steady progress of the College through several generations. It should not be subject to the fluctuations of whims from parties or people, but should be an investment for posterity. 'Art is long,' and the work of education for the art of agriculture must be permanent, in order to be reached by all.

"Ample equipment of buildings, furniture, and apparatus, farm and tools is of course necessary. It must even be more ample than in most colleges. Science, to be made practical, must be learned with laboratory practice; technical instruction is worthless without abundant illustration and exercise; and working habits can be formed only by handling the tools.

"A competent faculty must handle this machinery. The drill of such a college calls for greater ingenuity, if not for more general culture, on the part of the faculty, than most college courses. This is not mere teaching, but teaching adjusted to a specific want in life. It calls for a practical energy in addition to sound doctrine, for it deals less with authorities than with facts. New applications must keep them fresh in the life of toil which they are to elevate. The best in the land are none too good to hold the professorships in such a college; and should be found and kept if possible.

"Over all should preside an efficient and uniform control. The construction of this board should be such as to secure greatest stability with activity. Love for the work must inspire the members, and provident foresight direct them. The whiffling of popular sentiment for pork or mutton, for Shorthorns or Jerseys, must only make their course more steady and true to that line of education for farmers' sons which may give taste and ability for an enlightened and progressive agriculture."

\section{A PERIOD OF PROGRESS.}

The arrival of President George T. Fairchild gave a new impetus to the teaching force. The wish of the faculty and the board, that no radical changes be made in the policy, met with his fullest concordance. Yet his rich experience, the result of similar work at the oldest agricultural school of the land, soon bore fruit in the adop- 
tion of improved methods of instruction and a better adjustment of work and existing means. The collegiate year was divided into three nearly equal terms, of fourteen, twelve, and eleven weeks respectively, instead of two unequal terms as before. The course was strengthened by rearrangement of studies to logical connection; by systematic plans for connecting practice with theory; by introduction of stronger courses in place of elementary ones; by more definite classification of students, and by adding a term of psychology to the work of the fourth, and English literature and engineering to the work of the third year, - while the system of industrial training was broadened by distinct arrangement in shops, farm and garden, kitchen laboratory, dairy and sewing rooms. The preparatory, or "B" first-year class, was maintained only for the benefit of students from the country over eighteen years old who could not pass the entering examination. A scheme of Friday afternoon lectures and declamations was inaugurated, and weekly rhetorical exercises were added to the work of all classes. Monday afternoon faculty meetings for the discussion of ways, means and discipline were organized. Standing Committees on Grounds and Buildings, Public Exercises, Social and Literary Entertainments, Class Grades, PostGraduate Work, Farmers' Institutes, Museum, Library, etc., were appointed, and a more comprehensive system of accounting adopted, the Secretary of the Faculty, Mr. I. D. Graham, being given direct responsibility for accounts with all funds and all departments.

It is not possible within the limited space of this sketch to speak at length of the development of the College during the last twelve years. Many important phases, events, or reforms must be overlooked entirely, while many others of a recent date have not had time to produce their intended effects, and can hardly be considered history.

The number of students has increased every year except three, as may be seen from the following schedule:

\begin{tabular}{|c|c|c|c|c|c|}
\hline $\begin{array}{c}\text { Year. } \\
1878-79 .\end{array}$ & $\begin{array}{l}\text { Attendance. } \\
\ldots \ldots . .207\end{array}$ & $\begin{array}{r}\text { Year. } \\
188384 .\end{array}$ & $\begin{array}{l}\text { Attendance. } \\
\ldots \ldots .395\end{array}$ & $\begin{array}{c}\text { Year. } \\
1888-89 .\end{array}$ & $\begin{array}{c}\text { Attendance } \\
\ldots \ldots \ldots \ldots 445\end{array}$ \\
\hline $1879-80$ & ….276 & $1884-85$ & 401 & $1889-90$ & .51 \\
\hline $1880-81$ & 267 & 1835.86. & 428 & 1890-91. & .590 \\
\hline 1881.82 & .312 & 1886-87. & 481 & & \\
\hline 188 & $\ldots \ldots 347$ & $1887-88$ & .472 & & \\
\hline
\end{tabular}

The senior classes show a similar increase. In 1880, the class 
numbered seven; in 1888 , twenty-two; in 1889 , twenty-five; in 1890 , twenty-seven; and in 1891, fifty-two. In other words, the number of students has increased in eleven years nearly 200 per cent, and that of the graduating class has grown nearly 750 per cent. It is safe to state that there is no educational institution in the United States, no matter how richly endowed, that can show more favorable rate figures with regard to attendance for a period of more than ten successive years.

This phenomenal growth made necessary an increase in the teaching force, and this again made possible the assigning of the work of instruction to specialists. Among the teachers of special sciences who were added to the faculty during this period, and who have identified themselves with the peculiar work of the College, are: Professors E. A. Popenoe, A. M., who entered upon his work as teacher of horticulture and superintendent of orchards and gardens, in the fall of 1879 ; W. A. Kellerman, Ph. D., who was elected to the chair of botany in the fall of 1883 ; Nellie S. Kedzie, M. Sc., who took charge of the department of household economy and hygiene in the fall of $1882 ;$ D. E. Lantz, M. Sc., who became teacher of mathematics in the fall of 1883 ; Oscar E. Olin, who was called to the chair of English language and literature in 1886; and O. P. Hood, B. Sc., who entered upon his work as superintendent of the work shops and teacher of mechanics and engineering in 1886. Much of the success and growth of the College is due to the untiring efforts of these men, many of a reputation reaching far beyond the limits of the State or even the country. The annual reports of the several State and National societies for the advancement of pure and applied science give witness to the extended work carried on in the studies and laboratories of the College. Prof. W. A. Kellerman is the author of several publications on his special branches, as "Elements of Botany," a text book for schools, treating histology, vegetable and economic botany, and organography. At the time of its publication, in 1884, a critic in Science said: "It comes nearer to filling a serious gap in botanical literature than any other thus far published." Also, "Plant Analysis, or Key to the Dichotomal Plan for Identifying Plants East of the Mississippi." Also, "Analytical Flora of Kansas," and a "Kansas School Botany." The general use of these works attests their value. The Professor 
has also prepared numerous papers in various State Reports, the two of special importance to Kansas being "The Kansas Forest Trees Identified by Leaves and Fruit"- - the first work of the kind ever published in the United States - and the "Native Grasses of Kansas." Prof. Geo. H. Failyer has published a handbook for students of analytical chemistry, and Prof. Edwin A. Popenoe is the author of several students' handbooks on entomology.

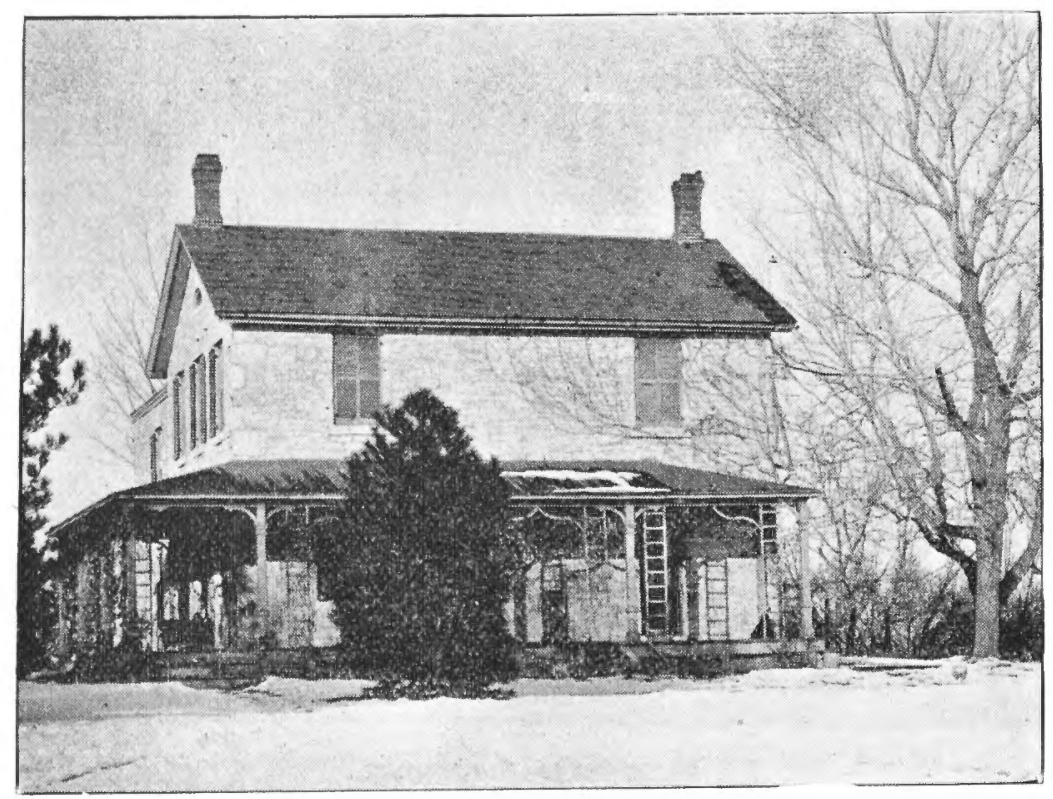

RESIDENCE OF PROFESSOR OF AGRICULTURE.

IMPLOVEMENTS FROM 1879 TO 1889.

The most important improvement made under President Fairchild's administration is the finishing of the main College building, $i$. e., of its central part, in 1882, of its south wing in 1884, and of its chapel addition in 1887 . The building was planned by President Anderson in 1877, and owes its peculiar form of three separate wings, or parts, connected by lower corridors to the expected difficulty of obtaining a sufficient appropriation by the Legislature for the entire completion in one fiscal period. The plans and superin- 
tendence were furnished for the principal structure by Architect E. T. Carr, of L deavenworth, and for the chapel addition by Prof. J. D. Walters. President Fairchild changed the original designs in several particulars, notably by adding an attic to the central part and a basement to the south wing - additions which, without materially increasing the cost, improved both the appearance and the capacity. The building as it now stands has cost about $\$ 70,000$.

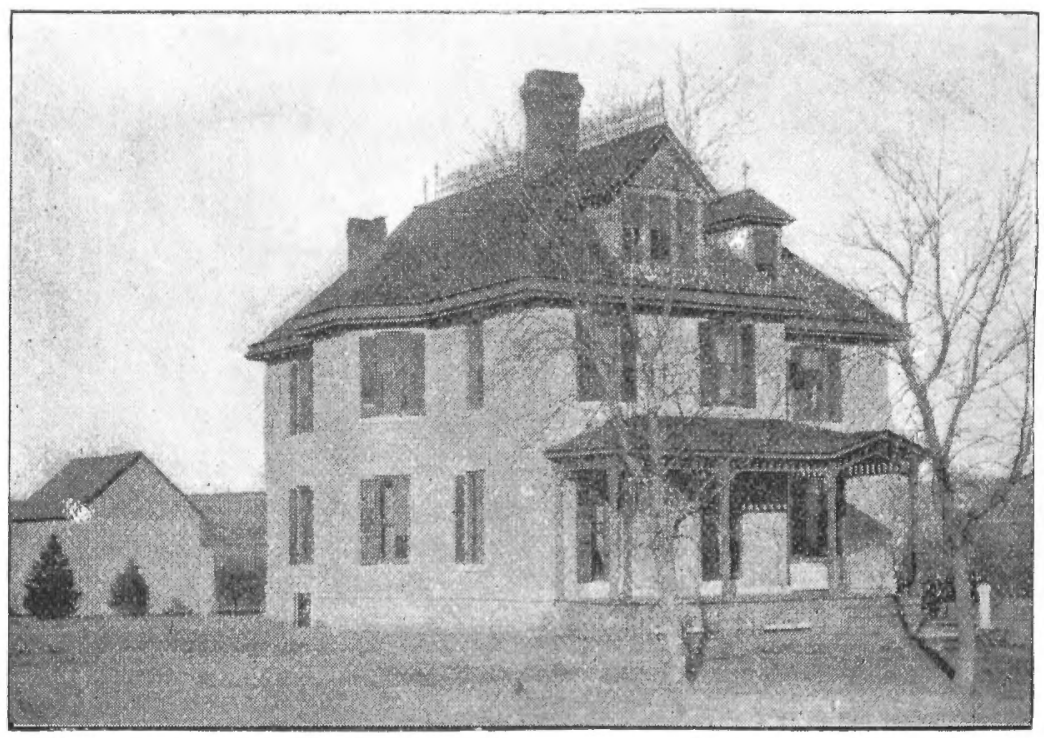

PRESIDENT'S RESIDENCE.

Of other permanent improvements, may be named the erection, in 1885, of the President's residence, ultimately to become the residence of the Professor of Horticulture; the construction of the north wing of the barn in 1885 , and the addition to this of the piggery in 1886; the rebuilding of Armory Hall in the same year; the placing in Mechanies' Hall of a steam engine and a number of fine wood-working machines in 1885-87; the building of the greenhouse in 1883; of the horticultural laboratory in 1888, and of the horticultural barn in 1889 . The plans and superintendence for these buildings were furnished by Prof. J. J). Walters. In 1883 and 1884, the main roads of the farm were gravelled, and in the 
spring of 1885 the grounds were platted for planting and future improvement in road building by a professional landscape gardener, Max. Kern, of St. Louis. In the same year a tract of forty-four acres of land was added to the farm by purchase, sixteen acres having been added some years previous. In the spring of 1891 another small tract of about four acres was bought. The College now possesses in two farms a total of 319 acres.

In 1888, the city of Manhattan built a very complete system of waterworks, with a pumping station near Blue River, and a capacious

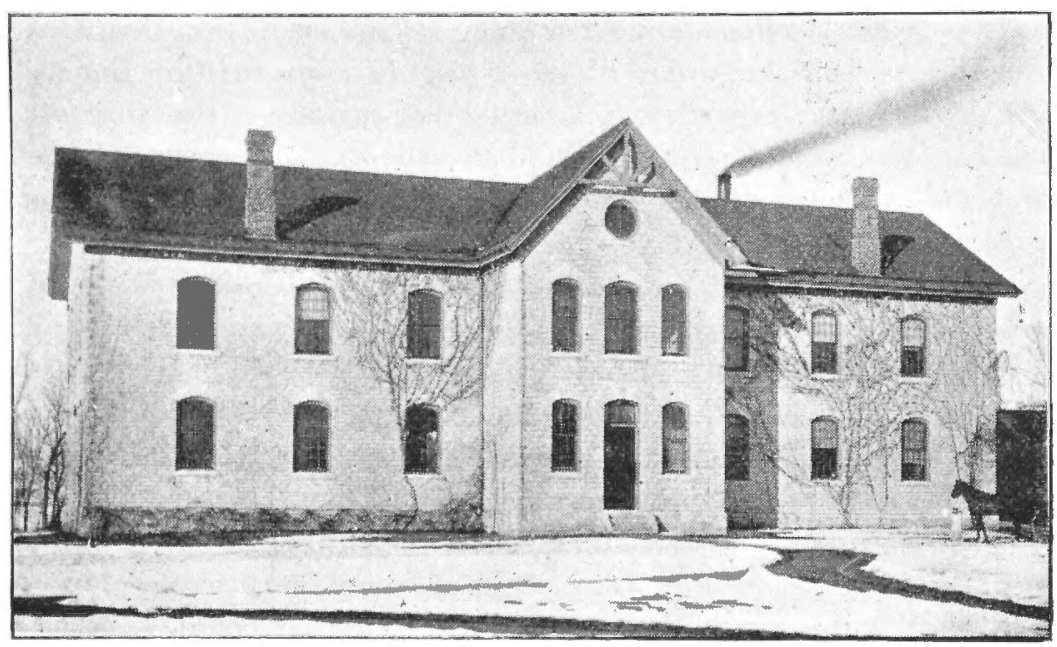

MECHANIC'' HALL.

double reservoir on top of Bluemont, a neighboring hill several feet higher than the tower of the main building of the College. In the following winter the Legislature appropriated $\$ 3,000$ for an extension of the pipe line upon the College campus, and about the 4th of July, 1889, the buildings, greenhouses and lawns were supplied with an abundance of pure water-a consiclerable factor in the economy of the scientific and agricultural departments, and a safeguard, in case of fire, for the buildings and other property, much of which could not be easily replaced. Another appropriation of $\$ 3,000$, made last winter for a further extension of the water service 
and for a system of sewers, will provide the College with a most complete water and drainage system.

\section{APPARATLS AND LIBRARY.}

Carefully-made purchases of scientific apparatus, and untiring efforts in gathering natural history specimens, have gradually provided the different departments with equipments valued altogether at more than $\$ 100,000$. Much credit for this is due to individual effort of the professors. The rapidly growing collections from the fields of zoölogy, botany, entomology, mineralogy and geology bave cost the College almost nothing. Not even the Board of Regents, perhaps, are aware of the esprit du corps existing among the faculty with regard to this and other matters. The greatest need of a school of pure and applied science is, however, a large and well selected library, and the establishment of this requires time and funds.

The library of the Kansas State Agricultural College is almost wholly the growth of the last twelve years. It was moved to its present quarters in the northeast wing of the main building from the northwest room of the old Bluemont College building, in 1878 , by acting President M. L. Ward, who was the librarian from 1875 until 1883. It consisted, at that time, of less than 1,250 valuable and well preserved books; the remainder, some 800 volumes, were either entirely worn out or they were works of almost no use or valueold Greek and Latin dictionaries and commentaries, religious monographs, sermons, old and poorly printed fietion, government reports, etc.-- a state of things not to be wondered at, when it is remembered that the greater part of the growth consisted of donations, solicited in the eastern states by President Joseph Denison and Agent I. T. Goodnow, and that during Anderson's presidency neither funds nor space were available for this purpose. Since then, however, there was rapid growth. Acting librarian, Prof. W. H. Cowles, reported the number of books on the shelves, June 30, 1884, at 5,740 bound volumes, 1,300 pamphlets, and several hundred duplicates. A card catalogue of topics was commenced by Prof. Cowles, and completed to date, in 1885, by acting librarian Prof. B. F. Nihart.

Prof. D. G. Lantz, the present librarian, took charge of the library in September, 1886. His first report catalogues 6,572 bound 
volumes, 2,350 pamphlets, and 360 duplicates, valued in the aggregate at $\$ 10,358.51$; and his report for $1887-88$ shows 7,453 bound volumes, 2,490 pamphlets, and 352 duplicate volumes, with a total valuation of $\$ 12,172.04$. One of the main endeavors of the faculty and librarian, has been to complete the sets of Government and State reports pertaining to agriculture, horticulture, finance and education, and hundreds of letters were written to Government officers in all parts of the country, soliciting such volumes. Sets of leading scientific and literary magazines were also completed by picking up missing numbers or volumes wherever there was a chance. The total of all State appropriations received for the library, up to date, is $\$ 6,000$.

At the close of the last fiscal year the library numbered 9,749 bound volumes, 349 duplicate volumes and 3,126 pamphlets-a total of 13,224. Purchases and donations during the present year have increased the total number to about 15,000. For these the inventory gives an estimated value of about $\$ 20,000$, but as a large number of books of great value to special students are out of print, the value to the College is much above these figures, and can really not be expressed in dollars and cents.

The library is in constant use by the students and the members of the faculty. The report of the librarian for the school year 1888-89 gives the total number of books drawn for home reading by students at $6,77 \%$, and the total number for the school year 1889-90 at 7,898 - an average of over fifteen books per student. This does not include the books and magazines read in the library or reading room, nor does it include the current numbers of periodicals of any kind, since these cannot be taken from the reading room. It is greatly deplored by the friends of the College that the State Legislature of 1891 has not been able to find means to appropriate more than $\$ 250$ annually for the next two fiscal periods for this purpose. A student of science without books is like a mill without water, or a stove without fuel. The great need of this College at this stage of growth is undoubtedly in the enlargement of its library facilities - it is more books and maps, and a new library building. 
EXPERIMENTS AND THE EXPERIMENT STATION.

If there is any section of the country that needs, more than any other, the painstaking assistance of the scientific agriculturist and experimenter, it is the prairie and mountain region of the West, where a climate unlike that of the older part of the United States and the civilized countries of Europe, make the selection of new crop plants and the adoption of new methods of tilling and husbanding an imperative necessity. It is natural that this necessity should have presented itself with great force to the managers of an institution founded for the purpose of educating the youth of the State for the vocation of the farmer. Experimental work in a small way, especially in the important field of forest planting, was commenced as early as 1868 , and was continued, as far as the limited means permitted, by Prof. E. Gale, who for many years was the president of the State Horticultural Society. In 1874 Prof. Shelton commenced a series of very valuable experiments in the cultivation of tame grasses, continuing his observations of varieties and species under different forms of treatment up to this date. Later on, experiments were made in sub-soiling, listing, feeding, etc., and the results were published in the IIcdustrialist and in freely distributed annual reports. Prof. Popenoe, following his predecessors in the work of horticulture, made a series of experiments in arboriculture, grape-growing, and vegetable gardening. This work was carried on chiefly at the expense of the College, though during the last dozen years the Legislature grudgingly assisted with a few paltry appropriations. In 1888 , however, the work gained a new phase by the assistance of the General Government.

The passage by Congress of the "Hatch Bill" in March, 1887, provided for the organization in each State of a station for experiments in lines promotive of agriculture. The Legislature at once designated this College as the proper place for the station, and measures were taken for such work. It was found, however, that no appropriation had been made for carrying out the provisions of the bill, and accordingly little could be done until February, 1888, at which time the appropriation was made. This placed $\$ 15,000$ in the hands of the Board of Regents for use during the year ending June 30th, 1888, and an equal sum for the year following. The organization of the Experiment Station was at once completed, and 
the work was begun. The general executive management of the station was placed under the control of a council, consisting of the President, the Professors of Agriculture, Horticulture and Entomology, Chemistry, Botany, and Veterinary Science. The President was made ex officio chairman of the council, and Prof. E. M. Shelton director of the station. The organic act permitted the use of one-fifth of the appropriation the first year for building purposes. From this source the Experimental Laboratory, with about 2,400 square feet of propagating pits was constructed. The station is now well equipped with men and apparatus, and ranks among the most efficient in the country.

Upon the resignation of Prof. E. M. Shelton in January, 1890, the office of director was discontinued and the clerical duties heretofore connected with that office given to the assistant secretary of the Board of Regents. The experimenting force of the station consists at present of five professors and five assistants. Since its organization there have been issued sixteen quarterly bulletins and two annual reports, the former containing current matter of general interest to farmers, horticulturists and stockmen, while the latter include full data of all completed experiments, with brief references to those still in progress. All bulletins and reports are distributed free to those who apply for them.

\section{A POLITICAL INCIDENT.}

Of incidents of a "political" character which had been frequent during the early history of the College, very little can be reported for the last ten years. The sessions of the State Legislature have had no influence upon its course of study or the quality of its work, and changes in the composition of the Board have hardly caused a ripple. Every new regent becomes impressed at once with the superior management of the whole institution. The only incident of any note is perhaps the enforced resignation of Professors M. L. Ward and J. E. Platt soon after the inauguration of a new Board of Regents appointed by Governor Glick in 1883. Prof. Ward had held the Chair of Mathematics for ten years, and Prof. Platt had taught in the College for nearly twenty years. The action of the regents was construed as partisan by students and graduates, and for several weeks the political press of the State was ablaze with 
editorials in denunciation or defense of the act. It is safe to estimate the quantity of "bull and bear" editorial with regard to this incident at two hundred newspaper columns.

\section{DEGREES.}

Before 1880 the College had not had occasion to give the second degree in course and the conditions under which this academic honor could be obtained, or post-graduate work leading in this direction could be done, had not been formulated and publicly stated. In that year the faculty adopted a code of rules and published it in the catalogue. Of the two hundred and thirty-two students, seventy-three of whom were young women, who graduated up to 1888, thirty-eight have pursued post-graduate studies under the adopted scheme, and twenty-six have been given the second degree. After undergoing several slight changes, the regulations for postgraduate work and degrees have crystalized into the following:

Arrangements can be made for advanced study in the several departments at any time. Special opportunity for investigation and research is offered at all times to resident graduates in Agriculture and Agricultural Chemistry, Physics and Chemistry, Horticulture and Botany, Zoölogy and Entomology, Mathematics, Engineering, and Drafting. Every facility for advancement in the several arts taught at the College is given such students, though they are not required to pursue industrial training while in such courses.

The degree of Bachelor of Science is conferred upon students who complete the full course of four years and sustain all the examinations.

The degree of Master of Science is conferred in course upon graduates who comply with the following conditions:

1. Each candidate must furnish evidence satisfactory to the faculty of proficiency in at least one of each of the groups of arts and sciences here named:

\begin{tabular}{ll}
\multicolumn{1}{c}{ Arts. } & Sciences. \\
Agriculture, & Botany, \\
Horticulture, & Chemistry, \\
Engineering, & Zoülogy, \\
Architecture and Desiguing, & Entomology, \\
Domestic Economy. & Physics.
\end{tabular}


2. Each candidate must present for consideration by the faculty a satisfactory thesis, involving original researches in line with one or the other of the courses pursued as above, and must deposit a perfect autograph copy in the college library.

3. Application to the faculty for sanction of the lines of study and research selected must be made as early as the first day of November, and the subject of the thesis must be settled upon as soon as the first day of January preceding the commencement at which the degree is expected.

4. Candidates must be from graduates of three or more years' standing, unless a post-graduate course of one year or more has been pursued at this College, in which case the second degree may be conferred two years after graduation.

Outlines of direction for study and research in various arts and sciences, with special adaptation to the wants and opportunities of individual applicants are furnished, at request, to all graduates; and professors in charge aid by correspondence in any researches undertaken.

The degree of Master of Science may be conferred upon the graduates of other colleges of like grade, and having similar objects with our own, on the following conditions:

1. The applicant for the Master's degree must be a graduate of at least three years' standing, and a resident of Kansas.

2. His post-graduate study must have been in line with that required of graduates of this College, as published in our catalogue.

3. He must make application for the degree on or before the first day of January preceding the granting of the same. The application must be accompanied with a statement of his course of study, the work upon which the claim for the degree is based, and the subject selected for his thesis.

4. By April 1st, an abstract of the thesis must be submitted to the faculty.

5. Before May 15th, the applicant shall present himself for examination. The examination shall be thorough and extensive, and shall be conducted by a special committee of the faculty. 


\section{OBJECTS.}

This College now accomplishes the objects of its endowment in several ways.

First, it gives a substantial education to men and women. Such general information and discipline of mind and character as help to make intelligent and useful citizens are offered in all its departments, while the students are kept in sympathy with the callings of the people. Entomology and mechanics are made prominent means of education to quick observation and accurate judgment. Careful study of the minerals, plants and animals themselves illustrates and fixes the daily lessons. At the same time, lessons in agriculture horticulture, and household economy, show the application of science ; and all are enforced by actual experiment.

Third, it trains in the elements of the arts themselves, and imparts such skill as to make the hands ready instruments of thoughtful brains. The drill of the shops, gardens, farm and household departments is made a part of a general education to usefulness, and insures a means of living to all who make good use of it. At the same time, it preserves habits of industry and manual exertion, and cultivates a taste for rural and domestic pursuits.

Fourth, it strives to increase our experimental knowledge of agriculture and horticulture. The provision for extensive and accurate researches made by establishing the Experiment Station as a distinct department of the College, offers assurance of more definite results than can be obtained by ordinary methods.

Fifth, it seeks to extend the influence of knowledge of practical affairs beyond the College itself. For this purpose it publishes the weekly Industrialist. Its officers also share in the debates and consultations of farmers and horticulturists throughout the State. Each winter a series of ten Farmers' Institutes is held in as many different counties of the State. In these the Faculty share with the people in lectures, essays and discussions upon topics of most interest to farmers.

\section{THE BOARD AND THE FACULTY.}

The government of the College rests with a Board of Regents, composed of seven persons, of whom one, the president of the fac-. ulty, is ex-officio, and the remaining six are members by appointment 
by the Governor, with advice and consent of the Senate. The term of office is three years. The Board have "full and complete power to adopt and enforce all necessary rules and regulations required under the law. They make all appointments of officers, principals, teachers, and employes which may be required for the practical and economical management" of the institution.

The Faculty of Instruction is composed of eighteen professors and instructors, two of whom are women, aided by twenty-one as. sistants and foremen. Two of the professors and seven of the assistants are graduates of the institution.

\section{HISTORICAL REMINISCENCES.}

The stone fence about the upper farm was built in 1869 .

The first Y. M. C. A. organization at the College was organized in February, 1872.

The college bell was donated to the institution, in 1864, by Joseph Ingalls, of Swampscott, Massachusetts, on the solicitation of Hon. Isaac T. Goodnow.

The Kansas State Agricultural College is the third institution of higher learning established in the State. St. Marys College claims to be the first, and Baker University the second.

There is not much danger of pupils receiving too much knowledge of God, truth and man, but godliness is vastly different from sectarian proselytism.-JoHn A. ANDERson.

The usual price for board in the Bourding Hall, during the first seven years, was $\$ 4$ per week, with an additional charge of $\$ 5$ per term for fuel and light. By putting two students together, the Hall was capable of accommodating sixty. In 1872 , when Col. F. Campbell resigned the stewardship, and Capt. A. Todd was elected, the price for board was reduced to $\$ 3.50$, and two years later to $\$ 2.50$ per week.

The rules of conduct as published in the catalogue of 1866-67 contained fourteen different paragraphs. President Anderson boiled them down to one: behave or leave. 
The Kansas State Agricultural College was one of the few educational institutions selected by the Interior Department to represent American education at the Exposition Universelle at Paris in 1889 .

Three of the specialists of the newly organized Department of Agriculture at Washington, D. C., are graduates of the Kansas State Agricultural College, while another received special training here as a post-graduate.

The commencement address of 1875 , by Noble L. Prentiss, "The World a School," has seen four different pamphlet and book editions. Some day when Kansas shall get ready to print its own school books "The World a School" will be given a place of honor in the High School Reader.

The first scientific organization at the Kansas State Agricultural College was "The Amateurs of Science." It was in existence in 1872, and met regularly once a week until the spring of 1873 . Candidates for admission had to pass a written examination in three branches of natural science. Prof. B. F. Mudge was the president and Miss Lizzie T. Williams the secretary.

"Undue social attentions will not be allowed," is the way the early catalogues put it. It could have been a little plainer yet.

The first good microscope that came into the possession of the College was ordered from Germany in 1872 by Prof. H. T. Detmers, D. V. S. It had three oculars and four lenses magnifying eleven hundred diameters.

In the summer of 1867 there were sixteen acres of the college farm under the plow and twenty-four more being broken.

The first locomotive passed over the bridge of the Blue, at Manhattan, in the summer of 1866 .

The first college catalogue, 1863-64, was printed by J. H. Pillsbury, of Manhattan, and edited by Prof. J. G. Schnebly.

Fifteen of the students of the Kansas State Agricultural College served in the United States army during the War of the Rebellion, and three of these died in the service.

The discovery of the inexhaustible salt beds of Kansas was anticipated by Prof. B. F. Mudge in several of his scientific articles, but the college catalogue of 1864-65 antedates the Professor's predictions, 
Many elderly gentlemen sufficiently know, and more young gentlemen will duly discover, that systematic knowledge of how cooking ought to be done is luminously different from the ability to do it.-Pres. John A. Anderson.

The catalogue of 1870-71 promised those who should complete in a satisfactory manner the course in agriculture, the degree of Bachelor of Agriculture, but for some reason or other the degree has never been conferred.

The stonework of the old Bluemont college building was done by John Soupine; that of the north and south wing of the main building, the laboratory, the horticultural hall, the mechanics hall, the president's residence and the north wing of the barn was done by Jacob Winne; that of the central part of the main building by the Ulrich Bros.; that of the piggery, the horticultural laboratory and the horticultural barn by Chas. Spongberg, and that of the south wing of the barn by William Allingham - all five of Manhattan.

The first telephone exhibited in Kansas was the property of Prof. Wm. K. Kedzie. It was constructed by the mechanical department after his directions. In the summer of 1877 , the Professor gave illustrated lectures on "the telephone and its construction and history" in a large number of Kansas towns. Supt. W. C. Stewart of the telegraph department accompanied him as manipulator and Prof. Walters furnished the cornet solos over the telegraph wires from the telegraphy class room in the mechanical building.

It is just as feasible to give practice in cooking, with pleasure and profit to the pupil, as it is to give laboratory practice in chemistry; and not more expensive. The work will chiefly differ from that of a kitchen, in the fact that, after a girl has learned to wash dishes or pare potatoes, she will not be kept everlastingly at either. -President Anderson.

In 1865 the value of the land endowment was estimated to be worth $\$ 400,000$; but in 1867 it was put at $\$ 500,000$, almost exactly the amount realized twenty years later.

In the summer of 1869 forty acres of the college farm were under cultivation. Forest trees for a wind-break and about four hundred fruit trees had been set out; also three hundred currant plants, one hundred gooseberries, tive hundred grape vines, ten 
varieties of roses, and a great number of flowering shrubs and ornamental trees.

The recent arrangement by which the students were permitted to share in the editorial work of the Industrialist, calls to mind that in 1875-77 the students of the College had a paper of their own. The name was News, and its editor Irving Todd. Chivalry does not permit the criticism of a dead gladiator.

The Alumui Association of the College at their commencement meeting, June 23, 1874, presented ex-President Dr. Joseph Denison with a silver ice pitcher, salver, goblet and bowl, as a token of esteem by his former pupils. The presentation speeches were made by Chas. 0 . Whedon, '71, and S. W. Williston, '72.

A prominent feature of the commencement exercises of 1880 , consisted in a public plowing match by the class in agriculture. The match took place on the ground southeast of the main college building.

The first farmer's institute, under the auspices of the Faculty of the Kansas State Agricultural College, was held in Manhattan, Janu. ary $2 \mathrm{~d}$ to $10 \mathrm{th}, 1872$.

The first item of the faculty records, as preserved in the vaults of the College, is dated February 19, 1866, and contains the resolutions passed by the Faculty in regard to the death of Prof. N. O. Preston. The Professor died of apoplexy in his class room, just before organizing his class in mathematies.

J. D. W. 


\section{HISTORY OF DEPARTMENTS.}

\section{DEPARTMENT OF PHILOSOPHY.}

The studies of logic, mental and moral philosophy, and political economy were naturally included in the classical course with which the College opened in 1863, being taught by Pres. Denison until 1873 , and by his successor, Pres. Anderson, until the reduction of the course in 1874, when the mental and moral science was dropped. In 1880 the present arrangement of studies in the course was adopted, making room for a term devoted to the study of human nature, a term in logic, a term in political economy, and a term in constitutional law. Pres. Fairchild had for many years taught political economy and moral science in the Michigan Agricultural College, and at once undertook the work in this department. The plan embraced text books in logic and mental philosophy, courses of lectures in practical ethics and in political economy, and Cooley's Principles of Constitutional Law. As the presidential duties increased, the constitutional law was first given temporarily to Prof. E. M. Shelton, and three years since associated with the chair of history. The political economy is now about to follow the same course.

\section{DEPARTMENT OF CHEMISTRY.}

In the summer of 1873 , the chair of chemistry and physics was established, and Prof. Wm. K. Kedzie was called to the place. Previous to this time, provision was made for teaching these branches by those whose principal work lay in other fields. Prof. Kedzie brought both energy and skill to its organization and equipment, and it took prominent rank among the departments of the College from the start. The work in the department was about equally divided between the two sections, chemistry and physics. From the beginning, the value, in a course of study, of handling the things about which one studies, was fully realized. The Chemical Laboratory was, therefore, equipped with the simpler apparatus to be used by students in their chemical practice or experimental work, as well as with some more expensive kinds for advanced work. 
With the removal, in 1875, of the College from the old quarters on the "hill" to the present location, and with the increase in the number of students, the need of a chemical building led to the erection of the present Chemical Laboratory in 1876. Its erection greatly increased the facilities for work. At first only a portion of the space in the building was utilized, but the increase in numbers and in the work in the department called continually for additional room, until now every room is fully occupied, and the crowded condition of the laboratory has, for the first time in its history, caused inconvenience. Of course this extension in working space continually called for additional outlays in apparatus, and in the more recent years, full equipment for advanced work has been added.

In 1878 Prof. Kedzie resigned, and Prof. G. H. Failyer, '77, was elected to fill the vacancy. In 1885, the department was divided, physics and meteorology being transferred to another department. Chemistry and mineralogy were left in the old quarters and this became the name of the chair, which was retained by Prof. Failyer. Previous to 1883 , there had been several student assistants, but no assistant proper. In this year, J. T. Willard, '83, was elected as assistant in chemistry, and retained the position until 1887. He was succeeded by C. M. Breese, ' 87 , who still holds the place.

With the establishment of the Experiment Station in connection with the College, in 1888, the Chemical Department of the College became also the Chemical Department of the Station, and J. T. Willard was chosen assistant chemist of the Station. He is still in this position.

The college catalogue of 1864-5 has this to say in enumeration of the apparatus owned by the College: "A large air pump, a first class electrical machine, one spirit lamp, two dozen test tubes and stand, two wide-mouthed, stoppered glass jars, two tall, plain, cylindrical jars, a gas-bag provided with stop cock and bubble-pipe, a set of small porcelain basins, glass tubing and small glass rods for stirrers, two small glass funnels, a mortar and pestle, platinum foil and wire, a set of cork borers, a steel spatula, a set of earthen crucibles, a pair of gasometers for oxygen and hydrogen." These were worth less than $\$ 150$. In 1890 , the inventory of the Chemical Department proper shows a total of $\$ 6,000$, exclusive of mineral collections and cases, valued at $\$ 2,700$. These items give some 


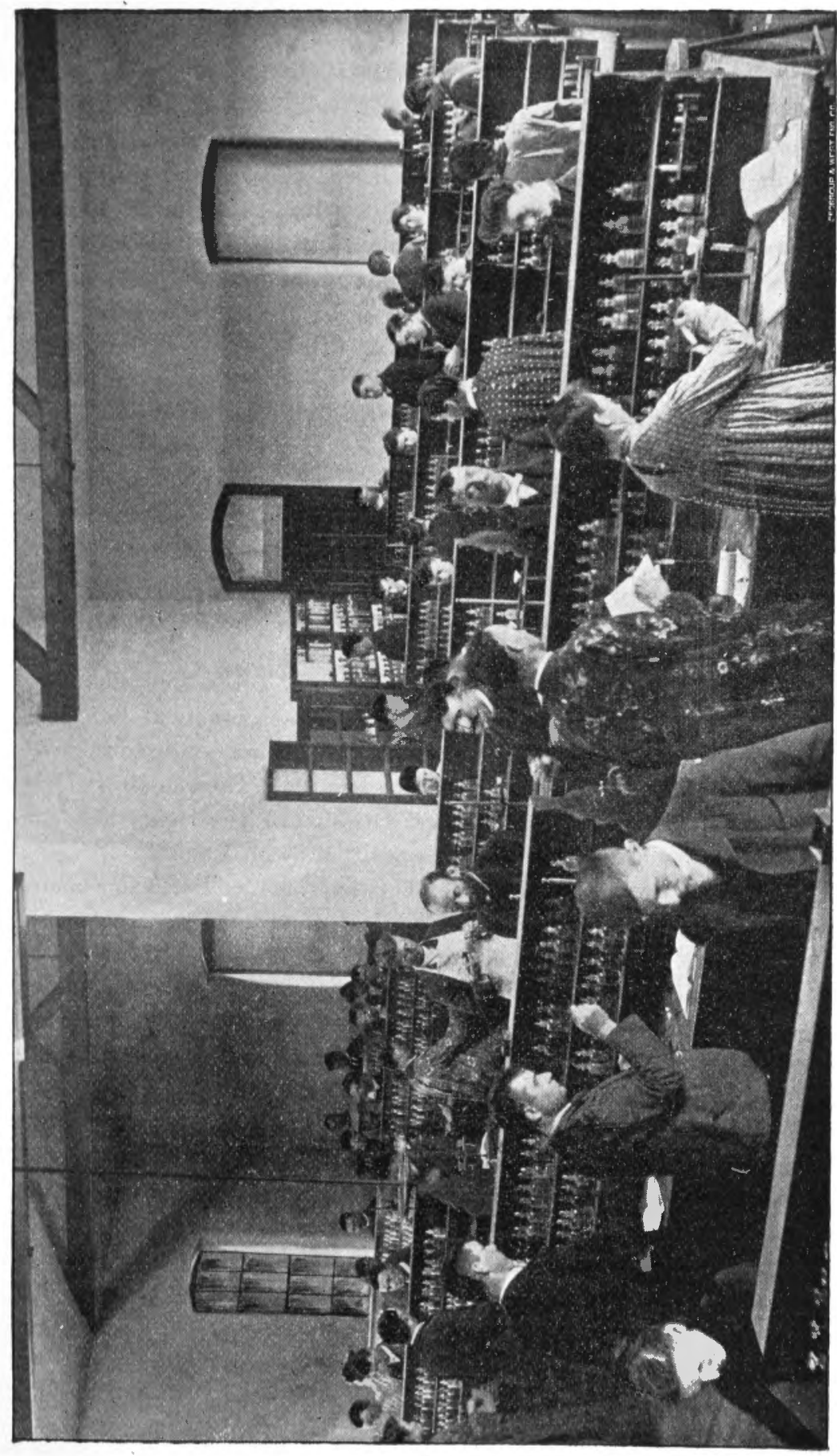

 
indication of the growth of the department and its importance in the general work of the College. It bas always been directly connected with the instruction in agriculture through a course in agricultural chemistry, and direct experiments in the chemistry of soils, products and growth, and is now doing special work for broadening the opportunities for farming.

\section{DEPARTMENT OF HOITTICULTURE.}

The department of Horticulture was first established in 1870, and placed in charge of Prof. E. Gale, a practical horticulturist, who had an extensive plantation of apples and small fruits, in connection with a fine nursery, on the northeast forty acres of what is now the college farm. During his administration, the work of the department was mostly in the line of the growing of nursery stock, although considerable attention was paid to a systematic and artistic arrangement of the grounds.

Prof. Gale resigned in 1878 , on account of protracted sickness, and was succeeded by H. E. Van Deman, also a practical horticulturist. At the end of a year, Prof. Van Deman was obliged to give up the work to attend to his private orchards. He was afterwards made the Chief of the Pomological Division of the Department of Agriculture at Washington, which position he still bolds.

In 1879, Edwin A. Popenoe, of Topeka, was elected to this chair, which he still fills. Under his able management, the work bas been systematized, extensive plantations of both fruit and forest trees have been made, and elaborate plans for the improvement and ornamentation of the college grounds have been executed so far as practicable.

In the early days of the College this department included, at various times and in various combinations, the branches of botany, zoölogy and entomology, but at present it merely includes the latter, which is, from its nature, intimately, almost inseparably, connected with horticultural work.

The present horticuitural building was constructed in 1876-7. A small greenhouse was attached in 1881, and in 1883 replaced by the present model greenhouse.

The following named persons have acted as foremen of the Horticultural Department, proper: A. Winder, G. E. Hopper, C. L. 
Marlatt and S. C. Mason, the latter being appointed in 1888, and at present holding the position, with credit to the department.

The greenhouse was, for a time, in the charge of Thomas Bassler, student, but the first foreman was Wm. Baxter, who was appointed in 1883 , and is still in charge.

\section{BOTANICAL DEPARTMENT.}

In 1883, the department of Botany and Zoölogy was established by separation from the Horticulture and Entomology, and temporarily included also two other branches, namely, physiology and geology. In 1888, when the Experiment Station was established, all the above branches except botany were transferred to the department of Physiology and Veterinary Science, and the department became in name and reality the botanical department. W. T. Swingle was then appointed Assistant Botanist. In April, 1891, he resigned, to take a similar position at $W$ ashington, D. C.

In 1883-4, the horticultural class room was occupied conjointly with the Professor of Horticulture and Entomology. The department took possession of the southwest rooms of the second floor, upon the completion, in the fall of 1884, of the south wing of the main college building. Two years later the armory building was remodeled, furnishing a recitation room, three laboratories, an office, and museum room, all on the second floor. The department then took up its permanent abode in these quarters. Museum cases were subsequently added to receive the various collections.

The equipment of the Botanical department includes, at present, about thirty microscopes, sets of tools, re-agents, charts, etc., for class use. For the work of the Experiment Station, various additional instruments and tools have been provided, including Zeiss microscopes, photographic and micro-photographic outfits, sprayers, culture room, work tables, etc., etc.

The botanical collections are included in a General Herbarium and a Kansas Herbarium. The department has the use, also, of Prof. Kellerman's very large private herbarium of fungi.

\section{DEPARTMENT OF MATHEMATICS.}

At the opening of the Agricultural College, in 1863, but one. department of study, the literary course, was put in operation. In it, the usual college course in mathematics, including calculus and 
astronomy, was announced. Rev. N. O. Preston was the first professor of mathematics. In the following year, other courses of study, with less of the mathematics, were announced. In 1866, Prof. B. F. Mudge was put in charge of the higher mathematics, while Prof. J. E. Platt taught the elementary mathematics. In 1870, the calculus was dropped from the course of study, and Professor Platt became Professor of Mathematics.

In 1873 , the course of study was entirely changed, the requirement in mathematics much reduced, and Prof. M. L. Ward elected to the chair of Mathematics and English. Professor Platt also remained in the chair of elementary Mathematics and English.

In 1883, the pure and applied mathematics were assigned to separate chairs, and Professor D. E. Lantz, received the former. The applied mathematics, except surveying, has since then been connected with the chairs of physies, and mechanics and engineering.

The equipment of the Mathematical Department consists of mathematical forms, five transits, four levels, plane table, farmer's drainage level, compasses, rods, chains, etc., all valued at $\$ 1,090$.

\section{DEPARTMENT OF INDUSTRIAL ART AND DESIGNING.}

Free-hand drawing became a branch of instruction at the Kansas State Agricultural College in 1870. The first teacher was Miss Lizzie Williams, an enthusiastic lover of art, and a talented student of the human form, who has since, as Mrs. Williams-Champney, won considerable fame as a skilled illustrator of juvenile literature. Art instruction in those early days was unsystematic, however, and the work in the department being optional with the students, the number of pupils was very small. Mechanical drawing was not taught nor studied.

The reorganization of the institution, in 1874 , made free-hand drawing a regular study. Prof. J. H. Lee, and afterwards, Prof. J. $\mathrm{S}$. Whitman, were the teachers. In 1876, a graduate of the College, Miss Ella Gale, a lover of art, at present the Professor of Art in Olivet College, Michigan, was given the position. Her marriage with Prof. Wm. K. Kedzie caused her to resign in $187 \%$. Her successor as instructor of Industrial Drawing was the present professor of the department of Industrial Art and Designing. 


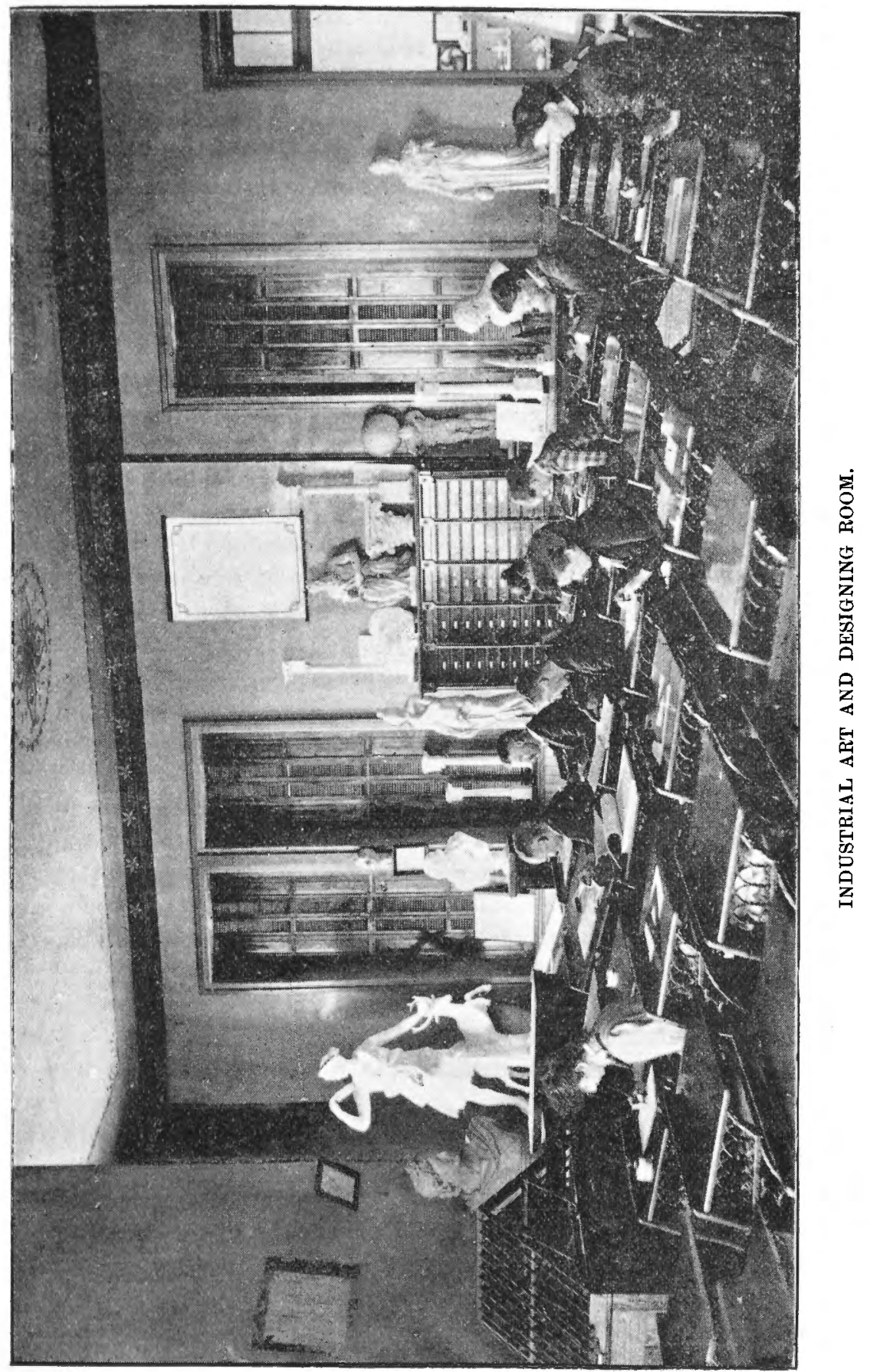


Under the care of Prof. J. D. Walters, who has now had charge of this branch of instruction for over fourteen years, the department has grown into a fully equipped school of mechanical drawing and industrial art, occupying two large class rooms, a private studio, a tool room and a store room for models. The inventory for the past school year shows equipments valued at $\$ 1,406.41$. A creditable beginning has also been made in starting an Art Museum. Besides a large number of art studies and art plates for illustration and imitation, the department possesses full size plaster paris casts of the Venus of Milo, and the Hadrian Diana with the Stag, also reduced casts of Angelo's Moses and his Lorenzo Medici, Thorwaldson's Hebe, Teed's Psyche, and several classic busts and tablets.

The obligatory instruction comprises a term of work in geometrical drawing and surface designing, a term of free-hand drawing, half a term of projection drawing, and a term of advanced work, machine and architectural draughting and study, linear perspective. Students who show special aptitude are encouraged to take drawing as a fourth study during any part of the course, and are given opportunity to fit themselves for the draughting office, or for special art schools.

During the past year the department has taught 665 pupils, i. e., 234 in the fall, 267 in the winter, and 164 in the spring. An increase of the work in drawing by the third-year class, agreed upon by the faculty and sanctioned by the Board at the April meeting, will probably make necessary the employment of an assistant.

\section{TELEGRAPH DEPARTMENT.}

With the reorganization of the College, in 1874 , under the policy formulated by President Anderson, telegraphy was given a prominent place as an art, especially for the young ladies, although it was open to both sexes, and a short telegraph line and the necessary instruments were provided.

Mr. Frank C. Jackson, then the U. P. telegraph operator at Manhattan, was placed in charge as superintendent, where he remained one year. His other duties demanding his time, he was succeeded, in 1874 , by W. C. Stewart, who remained in charge until the Bell telephone, then lately invented, proved more attractive, and he sev- 
ered his connection with the College to unite with the telephone company.

In 1879, I. D. Graham was elected superintendent, and held the position until 1890 . The records concerning the early history of the department are difficult of access, and little can be said of them. During the eleven years between 1879 and 1890, there were enrolled a total of 719 students in the department. Of these, 163 were ladies, and 556 gentlemen. The inventory of property belonging to the department has ranged between $\$ 257.25$ and $\$ 974.85$, and the yearly expenditures have been about $\$ 250$. In 1878 , by action of the Board of Regents, a fee of three dollars per term was collected from each male student, and the returns from this source have since nearly equaled the expenditures.

In 1890, E. R. Nichols was elected Instructor in Physics and Superintendent of Telegraphy.

Assistants in this department have been, in order: F. I. Parker, student; J. G. Harbord, '86; Agnes M. Fairchild-Kirshner; Bertha H. Bacheller, '88.

By action already taken, this department will be discontinued after the present school year, as less perfectly meeting the requirements of the times and of the State, in an education to the useful, than other arts which it is proposed to substitute for it in the course of study.

\section{DEPARTMENT OF ENGLISH.}

The English department was made a separate division of the College in 1882. Previous to that time the instruction in English was given in connection with other departments, especially those of Latin and mathematics. In 1863, when only the classical department had been established, English grammar and composition were taught by the Professor of Mathematics and Literature, N. O. Preston. In 1864, an agricultural course was outlined and grammar was made a part of it, with the addition of one term of rhetoric in the third year.

In 1866, besides the English of the preparatory department, one term of the sophomore year was given to rhetoric and criticism, and two terms of the senior year to philology and English literature, under J. H. Lee, Professor of Latin Language and Literature.

The course continued substantially the same until 1874, with the 
addition in 1871 , of weekly drill in composition, declamation, or other literary exercises throughout the course. In 1874, the College course was entirely changed, and English and history were placed together under J. H. Lee, as Professor of English and History. The next year it was again united with the department of Mathematics under Professors Ward and Platt, and so continued until 1882.

In 1882, English and history were again associated, and Prof. Wm. H. Cowles was called to this department. In 1885, Professor Cowles retiring to pursue special studies in the east, Oscar E. Olin was appointed head of the department. In 1888, English and history were separated and the department of English Language and I iterature established, Professor Olin being retained in the chair.

The course now provides systematic training in exact expression from the beginning to the end of the four years, with special reference to the etymology of scientific terms, and actual study of standard literature, with an outline of its history.

\section{DEPARTMENT OF HOUSEHOLD ECONOMY.}

The history of the department of Household Economy began when the college " handbook" was printed, in 1874. In this President Anderson said: "A girl has a right to an education as precisely adapted to a woman's work as is a boy's preparatory to a man's work." To educate the girls in such lines the sewing department was started during this year, and two years later, upon moving into the buildings on the present college site, the work was enlarged so as to really begin the study of household economy. Mrs. M. E. Cripps was in charge of the "Domestic Department", which meant the sewing, and a beginning of work for girls in other lines. She gave a short course of lectures upon special hygiene to the more advanced classes of young ladies, and these same classes listened to lectures by Prof. W. K. Kedzie upon the chemical composition of many articles of food, and some of the changes wrought by various combinations or by cooking. Prof. E. M. Shelton gave a few lectures upon the care of milk and the making of butter and cheese. These three short courses of lectures comprised the department of household economy. The sewing classes flourished, and in 1875 a class of girls was taught scroll sawing; but no actual work in cooking came into the College until 1877, when the southwest room in the 
chemical laboratory was fitted up for the senior class of girls to verify their lectures by actual experiment. A "baking day" came once a week, and during this year three meals were serred by the class, one on the occasion of a board meeting, one on " $W$ ashington's birthday," and one as a farewell "lark" by the senior class. The first was for the regents, the second for a few invited guests, and the third, with the help of Mrs. Cripps, was prepared by the girls of the class for their class brothers and themselves. In 1880 the course of lectures was extended, and in 1881 the lectures on household chemistry were put into the hands of Mrs. Cripps, and she organized a cooking class, which worked three weeks, and disposed of the food cooked by selling ten cent lunches to the students. About this time the kitchen laboratory was moved into the room in Mechanics Hall now occupied by the Industrialist, while the sewing department lived next door, in three rooms at the south end. In the fall of 1882, this work passed into the charge of Mrs. N. S. Kedzie, and the course in household economy was enlarged so as to cover twelve weeks, two hours per day. One hour was devoted to lectures, and one hour to cooking in the kitchen laboratory. Conveniences for good work were few, the bread and pies were often turned upside down in the oven in order to bake the bottom crust, and the water tank which supplied the building had a pleasant habit of running over and dripping through the pantry upon dishes, groceries, and any food that might be on hand.

Prof. Shelton conducted the department of dairying until the spring of 1884, when it was added to the already crowded department of household economy.

The following fall term the department was divided, Mrs. E. E. Winchip being employed to carry the classes in sewing. All this work was moved into the new south wing and given the comfortable suites of rooms now occupied by the two departments. New dishes were added, arrangements made for a regular "faculty dinner" on every Monday, and a students' lunch on every Friday of the cooking term, the charges made for each being barely sufficient to pay for the materials used in preparing them.

The "second-year party," which had in the old rooms only included the young ladies of the class, with a few invited guests, grew to include the whole second-year class; and the "regents' tea," held 
heretofore, grew to be a supper where regents, faculty and faculty wives met to test the cooking of ambitious second-year girls.

In 1887, the dairy was built; and since then the buttermaking has become a pleasure, while the cooking has crept over into the dairying term, in order to keep the large class busy. The cooking class, in the winter of 1883 , numbered twelve. That of 1891 num. bered thirty-six, with nine special students in the work, making forty-five cooks in the kitchen laboratory every day.

The pretty office belonging to the department, as well as the kitchen laboratory, the dining room, and the dairy, have been gradually fitted up with furniture until work is comfortably managed, even with large classes, and the history of the department of Household Economy in this College is really begun. Its influence is reaching into other State institutions, as the good work done in the Dakota College by Mrs. Dalinda Mason-Cotey, of the class of 1881, and that of Miss Abbie Marlatt, of the class of 1888, in the Agricultural College of Utah, testify. Other post-graduate students are preparing themselves to add still other pages to this history, while making history in the same line for other institutions.

\section{SEWING DEPARTMENT.}

The history of the Sewing department in the State Agricultural College began in December, 1873, when Mrs. Cheseldine, and three sewing machines, were given one corner of the chapel, and young ladies were regularly assigned to sewing. The next year the sewing classes were moved to the library, and were carried on very successfully, practical dressmaking and plain sewing of all kinds being taught.

In the fall of 1875 , upon moving into the new buildings, pleasant rooms were given to the Sewing depariment, in the place now occupied by the printing press.

In the year 1877-78, a small kitchen laboratory was started under the supervision of Mrs. Cripps, Superintendent of Sewing, until 1882, and Mrs. Kedzie, who succeeded her. The classes increased in size and much interest was taken in both lines of work, until the year 1884, when the Sewing Department was organized under the charge of Mrs. E. E. Winchip. It occupied the reception room for the fall term, until the large and commodious rooms that 


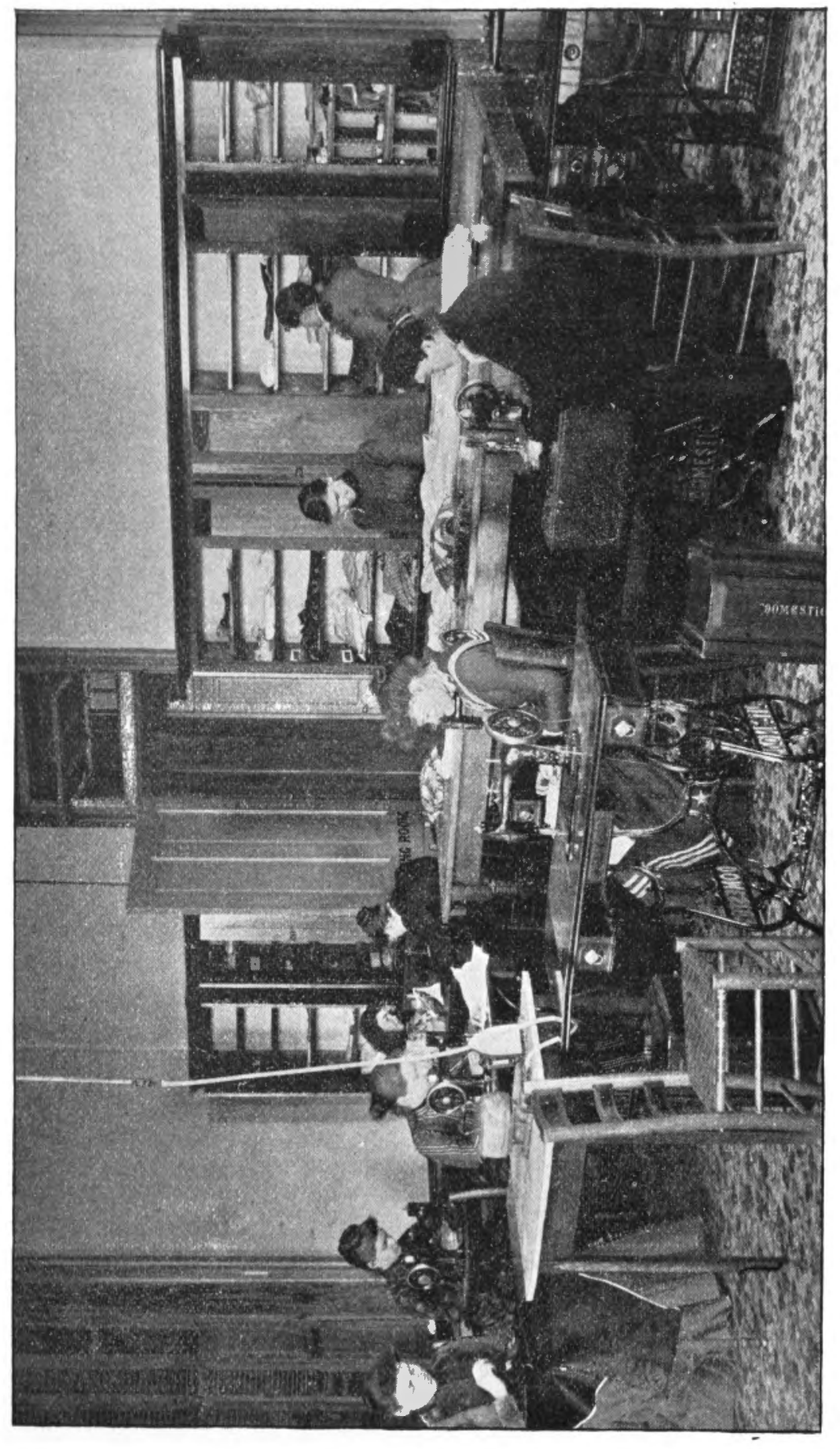

最 
we now have were completed. These are nicely fitted up with cupboards and drawers for keeping the work, most of the young ladies furnishing their own material and working for themselves. In this way nearly a thousand garments have been made in a single year, fully two hundred of them dresses fitted by the students themselves.

Since 1874, the number of students in sewing classes has increased from forty-five to over one hundred each day. Last year the department was too large for one pair of hands, and Miss Abbie Marlatt, a graduate of 1888 , was employed as assistant. This year she fills the chair of Household Economy in the Utah Agricultural College, and Miss Ada Little, '86, takes the same duties.

The department is recognized as one of the distinctive features of the College, and highly prized by the students.

\section{MECHANICAL DEPARTMENT.}

In 1871 a rude shed furnished room for a carpenter shop which received students into classes organized as those in any study, and blacksmithing was soon added. From this beginning the department has kept pace in growth with the general growth of the College.

In 1875 the second building on the present site was put up for a mechanics' hall. Some old students remember the shop in that year as a floorless, unplastered room full of industry, and with some special attractions not now in the course. Until about 1880 a few young ladies occupied one end of the shop at times in scroll sawing and wood carving.

In 1877 the shiop was floored, in 1884 plastered and wainscoted, in 1885 heated by steam, and at the same time an engine and line shaft were added.

The various heads of department have been Ambrose Todd, 1871 to 1878 ; T. T. Hawkes, 1878 to 1886 (except that M. A. Reeves was acting superintendent from 1882 to 1883 ); and $\mathrm{O}$. P. Hood since 1886. The assistants in the wood shop have been, in succession, M. A. Reeves, S. N. Peck, G. N. Thompson, and W. L. House, and in blacksmith work S. A. Hayes, J. Linder, J. Lund, and C. A. Gundaker.

The early practice of the shop was in learning so much of a trade 


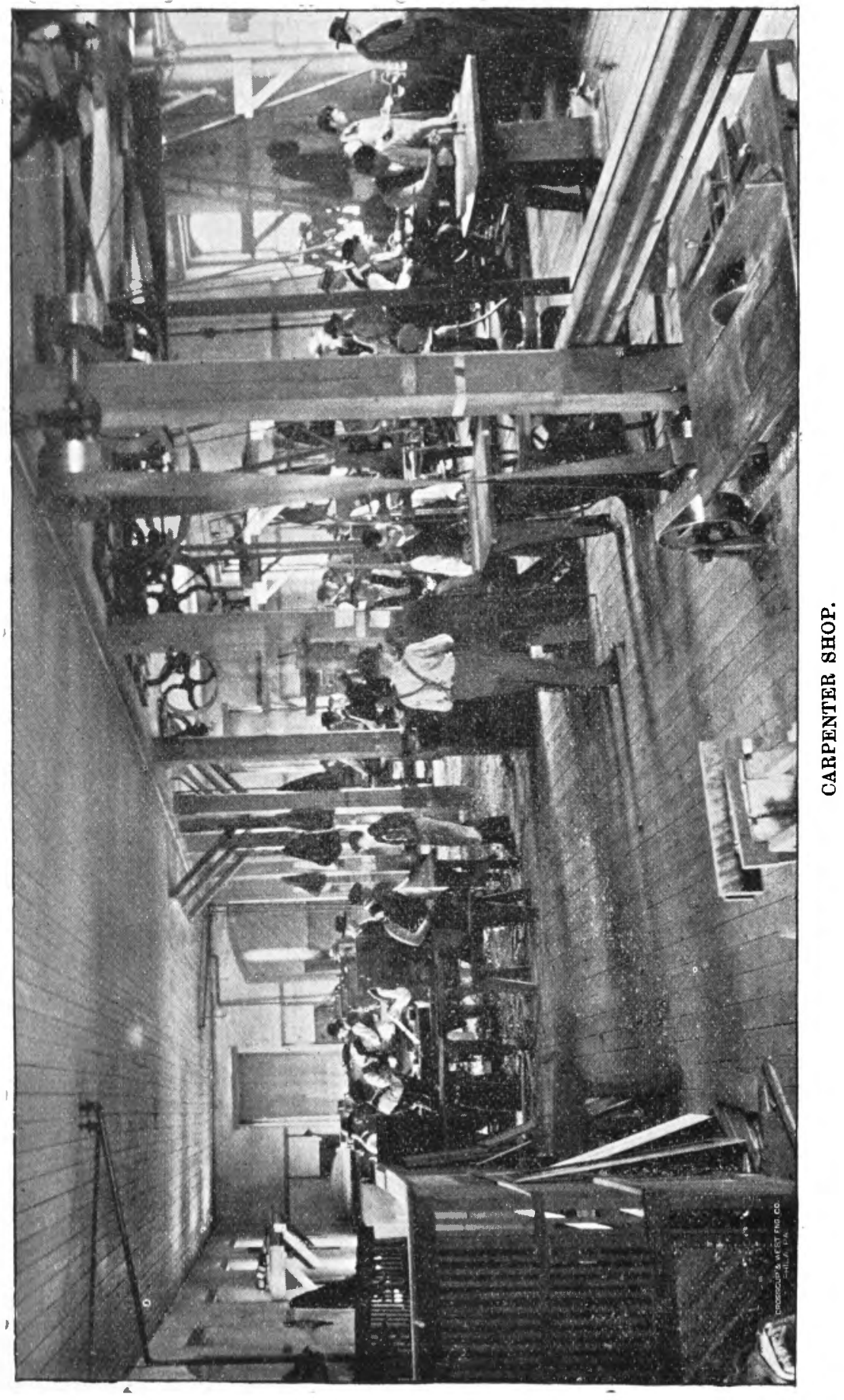


as was possible in limited time. In the fall of 1886 , the nature of the work was somewhat changed by the introduction of a systematic course in the elementary operations of wood work, and as soon as students came into the department, the use of carefully made drawings was insisted upon.

The Legislature of 1887 made provision for wood working machinery in the shop to the amount of $\$ 1,000$. In addition to the ten-horse power engine, and thirty-horse power boiler already in the building, a fine double-column circular saw of the best make was provided; also a twenty-four-inch planer, a single spindle friezer, a thirty-four-inch band saw, four lathes, and numerous attachments, making altogether, a very complete wood working plant as far as power machinery goes. The gradual growth of classes had required the addition of a room in the second story. Also in this year a very desirable combination was made by placing the general instruction in mechanics, as well as that in engineering, in charge of the superintendent of shops. It thus became possible to present the theoretical and practical parts of mechanics in harmony, greatly to the advantage of both.

During the past year, the department tools have been increased to 200 complete sets, placed in separate locked drawers under the benches, so that each student has a good kit of tools entirely in his charge. Special tools of great variety are found in an extensive kit, placed in order in a tool room, to be drawn out as needed by students, under a check system. The wood working part of the mechanical department is now thoroughly equipped and fit to handle the very large classes now in attendance. Its methods are such as to make its training felt beyond the use of wood working tools by fostering ingenuity, and awakening interest in all useful material. Much wood work of the department is represented about the College in buildings, cases and furniture.

In the past, iron work has of necessity been neglected on account of lack of equipment and funds. A small class in blacksmith work has been conducted since 1871, with two forges only, and a few tools. A $\$ 4,000$ building is soon to be erected for the iron work alone. The training in foundry, blacksmith shop and machine shop will be carried along the same lines as those followed in the wood work, making it neither technical training nor simply gymnastics, 
but discipline for future usefulness to the student in whatever industrial work he may be engaged.

The effects of the shop training have been noticeable from the beginning in cultivating efficiency of action and accuracy of judgment in matters of common concern, and multitudes of students all over the State testify to its merits in the training course for farmers. A few notable architects, builders and machinists have had the start in their life work here.

\section{DEPARTMENT OF MUSIC.}

The Musical department was organized in 1863. Instructors have been appointed as follows:

1863 Mrs. Ella C. Beckwith, Instrumental Music, . . . . . 1864 1864 Prof. Charles C. Heubschman, Instrumental Music, . . . 1866 1866 Mrs. Laura C. Lee, Instrumental Music, . . . . . . 1868 1866 Prof. J. E. Platt, Vocal Music, . . . . . . . . . 1883 1868 Miss Emily M. Campbell, Instrumental Music, . . . . . . 1869 1869 Mrs. Hattie V. Werden, Instrumental Music, . . . . . . 1877 1877 Miss Carrie Steele, Instrumental Music, . . . . . . 1878 1878 Prof. Wm. L. Hofer, Instrumental Music, . . . . . . . 1886

In 1886 the present incumbent, Alexander B. Brown, was appointed Professor of Vocal and Instrumental Music. In 1889 Miss Susan W. Nichols was his assistant, followed by Miss E. Ada Little in $\mathbf{1 8 9 0 .}$

At first the department was little more than a singing school, with a single piano as its equipment; but, keeping pace with the continuous and general development of the College, it is now almost a conservatory in its opportunities for study, though still limited in those for practice. At first music was considered only a special study; now it may be taken at any time by ladies, as an industrial, and by special arrangement may be taken as a study, not as an accomplishment merely, but disciplinary as well; in its acquirement not only exciting the emotions, but quickening the intellectual powers.

Its methods combine with the first lessons instructions in harmony and rythm, which constitute a foundation for whatever superstructure the taste, talents or necessities of the student may require; and this without increasing the time for the rudimental studies, because of the improved text books and charts. 
The prismatic charts, nine oil paintings twelve feet four inches square, are an original presentation of the doctrine of expression, and have received the endorsement of several of the best musicians, teachers and artists of the country, most notable of these, Remenyii, the world renowned virtuoso. They are the mutual work of Rev. Robert Brown, of Kansas Conservatory, Leavenworth, and Prof. A. B. Brown, assisted by Miss M. J. Douglass, and painted by Wm. J. $\mathrm{McNutt}$, under their direction.

The present equipment for practice and effect, in addition to the prismatic charts - a duplicate set of the original - and a small library, are: five pianos, one a Chickering concert grand, four organs, one a pedal organ, and a double bass, with other necessary furniture. Other orchestral and band instruments, with text books, are furnished by the head of the department for a small rental.

The daily opening exercise at chapel is at present led by an orchestra of twenty members and a choir of eighty voices, the other four hundred students, furnished with books, constituting the grand chorus. By means of this daily drill of the year and the weekly rehearsals of the singing classes and orchestra, the commencement exercises furnish a musical program more interesting than any number of hired professionals could present.

The department furnishes the musical numbers for all college exercises, assists the literary societies, and has for the promotion of higher culture: the Glee Club for gentlemen, the Cecilia Society for ladies, the orchestra for ladies and gentlemen, and the Cadet Band, which furnishes music for the battalion drills of the military department and other occasions.

Under the direction of the department, the oratorio of "The Creation;" the cantata, "Jephthah and his Daughter;" the operas, "The Chimes of Normandy" and "The Bohemian Girl" have been successfully rendered by students and citizens in the opera house at Manhattan.

\section{PIINTING DEPARTMENT.}

The Printing department was established in December, 1873, as part of President Anderson's general scheme to give industrial training greater prominence than it had hitherto enjoyed. Twenty-five pairs of cases, 200 pounds of long primer type and a proofpress were provided. This material was used wholly for practice 
in type-setting and drill in punctuation, capitalization and syllabication, no paper being printed at that time. Classes were taught by President Anderson and M. Schillerstrom.

A. A. Stewart was made Superintendent of Printing in April, 1874, having a class of fourteen persons, which was increased to thirty-one during the following term.

The first number of the Industrialist bears the date Saturday, April 24, 1875. President Anderson was managing editor, and J. H. Folks, business manager. The paper was a three-column folio, and the type used was brevier and nonpareil. The salutatory stated that the paper was issued "in part, to afford the members of the printing classes regular drill in the work of printing and publishing a weekly newspaper; in part, to epitomize current events for the benefit of its student readers; in part, to photograph the work of the several departments of the Agricultural College for the information of its patrons and the people; in part, to discuss the educational system and methods of Kansas from the standpoint of the rights and necessities of the industrial classes; in part, to contribute, so far as it can, such practical facts of science as may increase the profit.or pleasure of the farmers, mechanics, or business men or women of Kansas."

Mr. Stewart resigned in 1881, and Geo. F. Thompson, a thirdyear student, was elected to fill the vacancy. The rapid increase in the subscription list of the Industrialist made necessary improved facilities, and the half-medium Gordon job press on which the paper had been printed for seven years gave place, in 1882, to a Babcock country cylinder, which is yet in use. A small (eighth medium) Gordon job press was added about the same time. The paper, meanwhile, had been enlarged to a four-column folio.

J. S. C. Thompson, the present incumbent, was elected superintendent in January, 1887. In 1889, the Industrialist underwent a typographical change, the size of the sheet being slightly increased, the columns reduced in number to three to the page and increased in width, and ten-point type employed as a "dress." The display type in the office being well nigh worn out by this time, it was thrown out, and new faces, on the uniform standard system of bodies shortly before agreed upon by the type-founders, put in. A year later about twenty fonts of wood type,- the first to find a 
place in the office,- - a rule cutter, a rule curving and a rule mitering inachine were added. The present equipment consists of cases and stands sufficient for the accommodation of a hundred students, and the attendance has at different times nearly reached that figure. Besides the Babcock cylinder press with steam power, for newspaper and book work, there is a quarter-medium new Liberty (just purchased), and an eighth-medium Gordon for smaller work. The inventory of the department is about $\$ 4,000$, against $\$ 1,197$ in 1876.

\section{DEPARTMENT OF HISTOKY AND CONSTITUTIONAL LA $r$.}

Before the reorganization of the College in 1873, modern history, Grecian history, general history and United States history were taught at various times and in different parts of the course of instruction. For several years after that event United States history was taught in the first year of the "Woman's Course" and general history in the later years of other courses. Since the year 1879 , United States history has been a winter term study of the first year, and general history a fall term study of the third year, and constitutional law a winter term study of the fourth year, except that in 1881; the last named was pushed forward into the spring term. The new course of study which will go into effect during the year 1891-2, provides that United States history shall be required on entrance; general history shall be as now in the fall term of the third year, and that a course in constitutional history and civil government shall be given during the winter term of the third year. Constitutional law is dropped from the curriculum. Political economy, now taught in another department, will be transferred to this, and the chair name will probably be changed. All training for citizenship will, hereafter, be under one instructor. Though others have been teachers of history in the College, only the following have been designated as such by the catalogue: President Denison, 'r0-3, history, political economy, and mental and moral philosophy; Prof. J. H. Lee, '74-5, English and history; Prof. W. H. Cowles, '82-5, English and history; Prof. O. E. Olin, '85.8, English and history; Prof. F. H. White, '88.-, history and constitutional law. 


\section{FARM DEPARTMENT.}

Though nominally an Agricultural College since 1863, this institution was without any instruction in agriculture until 1868, when J. S. Hougham was elected Professor of Agriculture, and taught all there was in the College of book-keeping, commercial science, general and analytical chemistry, and physics; his title being changed several times to fit his duties. This concentration in one chair of so many essential studies of the College is presumptive proof that but little could be accomplished in any of them. Under such conditions the progress would necessarily be slow.

In $\mathbf{1 8 6 7}$, eighty acres of the farm were inclosed by a stone wall, a few acres having previously been broken. In 1868, an apple orchard, the same which still stands there, was planted in this inclosure, at an expense of fifty cents per tree, the planting being let by contract to Mr. Samuel Cutter, still living in Riley county. In the winter of 1868.9 the legislature made its first outright appropriation of $\$ 200$ for the Agricultural Department, restricting its use to the purchase of plants, seeds and agricultural implements. As a matter of interest it may be noted that the same legislature appropriated $\$ 1,400$ to furnish tobacco for the convicts in the penitentiary.

So far "No provision had been made for the grunt of pig, bleat of sheep, low of cattle, or neigh of horse, which might disturb the literary and classical repose of even a more conservative institution of learning." No cropping had been attempted. In 1869, the few acres that were broken were rented to Col. Frank Campbell, who kept the college boarding house. In 1870, Prof. Hougham planted the first crop, consisting of oats, barley and corn. The season was unfavorable. The oats and barley grew only six to eight inches tall, and the corn was all but destroyed by chinch bugs. In August of the same year, the ground was sown to wheat, and in 1871 gave a yield of forty-three and one-half bushels per acre.

In July of 187.1 , two valuable tracts of land were purchased. One, the so-called "Ingram place," consisting of eighty acres in the Wild Cat bottom two or three miles from the College, was never used, but sold in 1880 . The other, containing one hundred and fifty-five acres, joined the town of Manhattan on the west, and is the present site of the College. Of this, forty acres were bought from Mrs. Preston, forty acres from Prof. Gale, and seventy-five 
from Mr. Foster. The total cost being $\$ 29,832.71$ in scrip, of which sum the city of Manhattan contributed $\$ 12,000$, raised by a bond election.

In 1871, Fred E. Miller, was appointed Professor of Practical Agriculture, and means were provided for the purchase of stock, teams and implements. The foundation was laid for a herd of Shorthorns, which still remains the pride of the College. The "new farm" near town was put under culture, and an immense stone barn was projected and the building of the first wing begun. This wing was, however, all that was ever finished of the grand structure, and it did duty as a barn for but a few years. In 1875 the institution was removed from the classical halls of Bluemont College to the new farm near town, and the barn was converted into a temporary main building, with class rooms, laboratory, chapel, etc., and later, when the present main building was finished, it was, and still is, used for museum, armory, botanical laboratory, etc.

In April, 1874, Mr. E. M. Shelton, a graduate of the Michigan Agricultural College, was made Professor of Practical Agriculture, and remained in the chair till the close of 1889 , when he resigned to go to Australia - a period of nearly sixteen years. His strong personality and energetic nature made itself felt, not only in the management of the department, but in the agriculture of the State, and established the repute of the College for practical and experimental agriculture.

During these sixteen years the department made a steady forward growth. Much attention was given to the herd. The Shorthorns were bred up, and samples of other breeds were added, namely, Galloways and Jerseys, and later on, Herefords and Aberdeen Angus, the Galloways being displaced by the latter. The constant growth of the College necessitated encroachments on the tillable land of the farm for building sites, lawns, and horticultural work, and the need of more land grew yearly more pressing. To meet this need, the college authorities purchased sixty acres from the heirs to the Beebe estate, which joined the college property on the north. Sixteen acres of this was conveyed to the College July 22, 1881, and the remaining forty-four acres in August, 1885.

A new stone barn was built in 1877 , dimensions $97 \times 48$ feet, at a 
cost of $\$ 4,000$, and in 1885 a wing was added to it, measuring $75 x$ 50 feet, and costing $\$ 4,500$.

On the resignation of Prof. Shelton in 1889, Chas. C. Georgeson, also a graduate of the Michigan Agricultural College, was appointed to the chair of Agriculture, and took charge on his arrival, January 4,1890. During that year some fine specimens of Holstein-Friesian cattle were added to the herd, and a couple of Shropshire sheep were purchased with a view to rearing a flock of that breed. Field experimenting was also much extended.

The farm department has at present one hundred and eighty-five acres under its control, one hundred and seven acres of which are in pasture, and the remainder under culture. The live stock in its possession includes Shorthorn, Jersey, Aberdeen-Angus, Hereford, and Holstein-Friesian cattle; Berkshire and Poland China swine, and Shropshire sheep. It has two good teams and all the necessary implements of tillage. The inventory taken June 30, 1890, showed the value of the assets, exclusive of the farm, to be $\$ 26,716.70$.

All of this property is used directly for instruction in the principles of agriculture, and since the organization of the Experiment Station, in 1888, has been devoted in great measure to experimental agriculture, fully reported in bulletins of the station. At present, there are some eighteen hundred plots in general farm crops under observation.

The foremen in this department have been: J. C. Mayos, T. B. Morgan, W. S. Myers, E. Gregory, W. Whitney, G. R. Wilson, and $\mathrm{Wm}$. Shelton, the latter being still in charge. In 1888, when the station experiments were undertaken, Mr. H. M. Cottrell, M. Sc., was made assistant in agriculture, and retains the place at the present time.

\section{MILITARY DEPARTMENT.}

In the act establishing the Agricultural College, it was provided that military instruction should be made a part of the course. To carry out this provision, Gen. J. H. Davidson was appointed military instructor in 1866, three years after the founding of the College. During his service the College received from the State one hundred of the inferior muskets used during the fore part of the Rebellion.

For a year or more the outlook of the department was promising, 
but interest in military drill soon died out, and Gen. Davidson was removed in 1870 . From this time till 1881 there was nothing done in the way of military instruction, and what equipments had been acquired were either lost or destroyed.

In the suinmer of 1881,1 st Lieut. Albert Todd, of the 1st Artillery, was assigned to duty here by the War Department, as Professor of Military Science and Tactics. Classes in drill in the schools of the soldier, skirmisher, company and battalion were immediately organized, but no equipments were received until May of 1882. At this time the department received seventy-five stands of improved rifles from the $W$ ar Department of the United States, and the board of regents provided swords for the ofticers.

A class was organized in military science about the same time, and the study has since been a part of the course required in the College.

In 1884 Lieut. Todd was succeeded by Lieut. W. J. Nicholson, of the 7th Cavalry, during whose administration the equipments were extended by the addition of twenty-five rifles from the government, and the purchase of sixty uniforms. At the expiration of Lieut. Nicholson's term, Lieut. J. F. Morrison, of the 21st Infantry, was appointed to the position, which he held for three years, with the addition of fifty rifles and sixty caps and blouses, and two three-inch rifled cannon, so that at present there is abundant opportunity for students to become well versed in the artillery as well as the infantry drill.

Lieut. E. B. Bolton, of the 23d Infantry, has been on duty in the chair of Military Science and Tactics since August, 1890, and the department has been furnished with a new stand of colors and trumpets for battalion drill. Although the drill has been elective in all these years, it has become more and more effective and popular with the students, so that a young man seldom goes through a year without one or more terms of regular drill, and the battalion reaches the full capacity of equipment.

\section{DEPARTMENT OF PHYSICS.}

The teaching of natural philosophy, physics and meteorology has been variously connected with established chairs in the College since the beginning, in 1863 , and its history up to 1887 is connected 


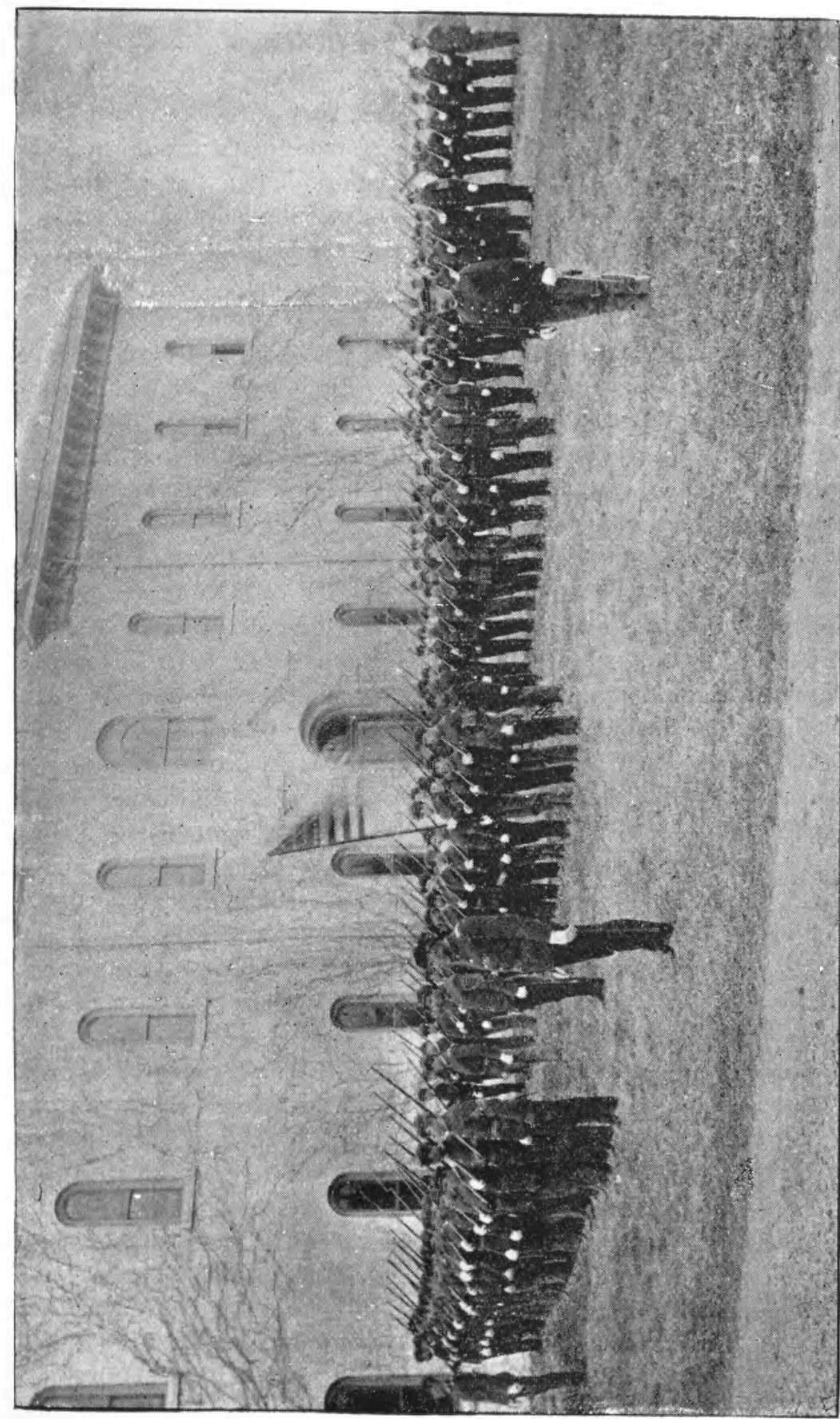

总 
with the chairs of natural sciences, chemistry, and mechanics and engineering. In 1887 F. J. Rogers was made Instructor in Physics, and taught it two years, with other studies. Upon the retirement of Mr. Rogers to pursue extended study of the physical sciences, Lieut. J. F. Morrison, Professor of Military Science and Tactics, took charge for a year, until the expiration of his detail for service here. In 1890 Ernest R. Nichols was elected Instructor in the chair of Physics, with a view to including the whole subject of electrical engineering. The department is well supplied with apparatus for general illustration, and is now gaining apparatus for accurate physical measurements, especially in electricity. The inventory of illustrative apparatus amounts to over $\$ 3,500$ now, with prospect of a considerable increase another year.

\section{DEPARTMENT OF VETERINARY SCIENCE,}

Instruction in Veterinary Science was first given in 1871, in a course of lectures by Mr. Joseph Rushmore. In 1872, Dr. H. J. Detmers was made Professor of Veterinary Science and Animal Husbandry. The course was planned for four years. In 1874, Dr. Detmers resigned. In 1887, Dr. Paquin gave a course of ten lectures. In 1888, a chair of Veterinary Science and Physiology was created and Dr. Robt. F. Burleigh occupied it for one year. In 1890 , Dr. N. S. Mayo was selected to fill the chair. The time devoted to the general lectures has been extended from the last two weeks of the winter term to the whole winter term of the fourth year, and the study of physiology and zoölogy is under the direction of the same professor with the purpose of making them, in a sense, preparatory to the veterinary course.

This chair is directly connected with the Experiment Station, its occupant being, ex-offcio, a member of the council.

\section{THE EXPERIMENT STATION.}

Since the organization of the departments of agriculture and horticulture, experiment has been prominent in the thoughts for development of these departments, and so far as the funds of the College permitted, work has been done in this line. Previous to 1888 , reports of such undertakings were published in connection with the biennial report of the regents, and contain a considerable 
body of interesting matter pertaining to Kansas farming and orcharding.

In February, 1888, when the funds appropriated by Congress to carry out the provision of the Hatch Experiment Act of 1887 became available, the Station in this State was immediately organized as a department of the College. The heads of the departments of Agriculture, Horticulture, Chemistry, Botany and Veterinary Science, with the president of the College were made, ex-officio, members of the council, in full control of all experiments. Rooms were assigned to the special work of the several departments, competent assistants were employed, extensive propagating houses were erected, apparatus was supplied, and all the farm and garden machinery, including lands and stock, were placed at the disposal of the Station for such experiments as might be most advantageous to the State. Bulletins have been issued from time to time to the number of seventeen, and the annual reports have made volumes of over 300 pages.

The Station stands in good repute with the thrifty farmers of the State, and with other investigators throughout the country. Some of its workers have been called to more prominent positions in other States, and in the Department of Agriculture at Washington.

The organization of the Station as a department of the College with a council in full direction made the office of director, held in 1888 and 1889 by Prof. E. M. Shelton, chiefly nominal, except so far as it concerned the correspondence of the Station and its publications. In January, 1890 , the assistant secretary of the Board was made, ex-officio, secretary of the Station council, with direct responsibility for the accounts, the clerical work, and the issue of bulletins and reports. The Station council now stands as follows:

Geo. T. Fairchild, A. M., Chairman.

Geo. H. Failyer, M. Sc., Chemistry.

E. A. Popenoe, A. M., Horticulture and Entomology.

W. A. Kellerman, Ph. D., Botany.

C. C. Georgeson, M. Sc., Agriculture.

N. S. Mayo, D. V. S., M. Sc., Veterinary Science.

I. D. Graham, B. Sc., Secretary. 




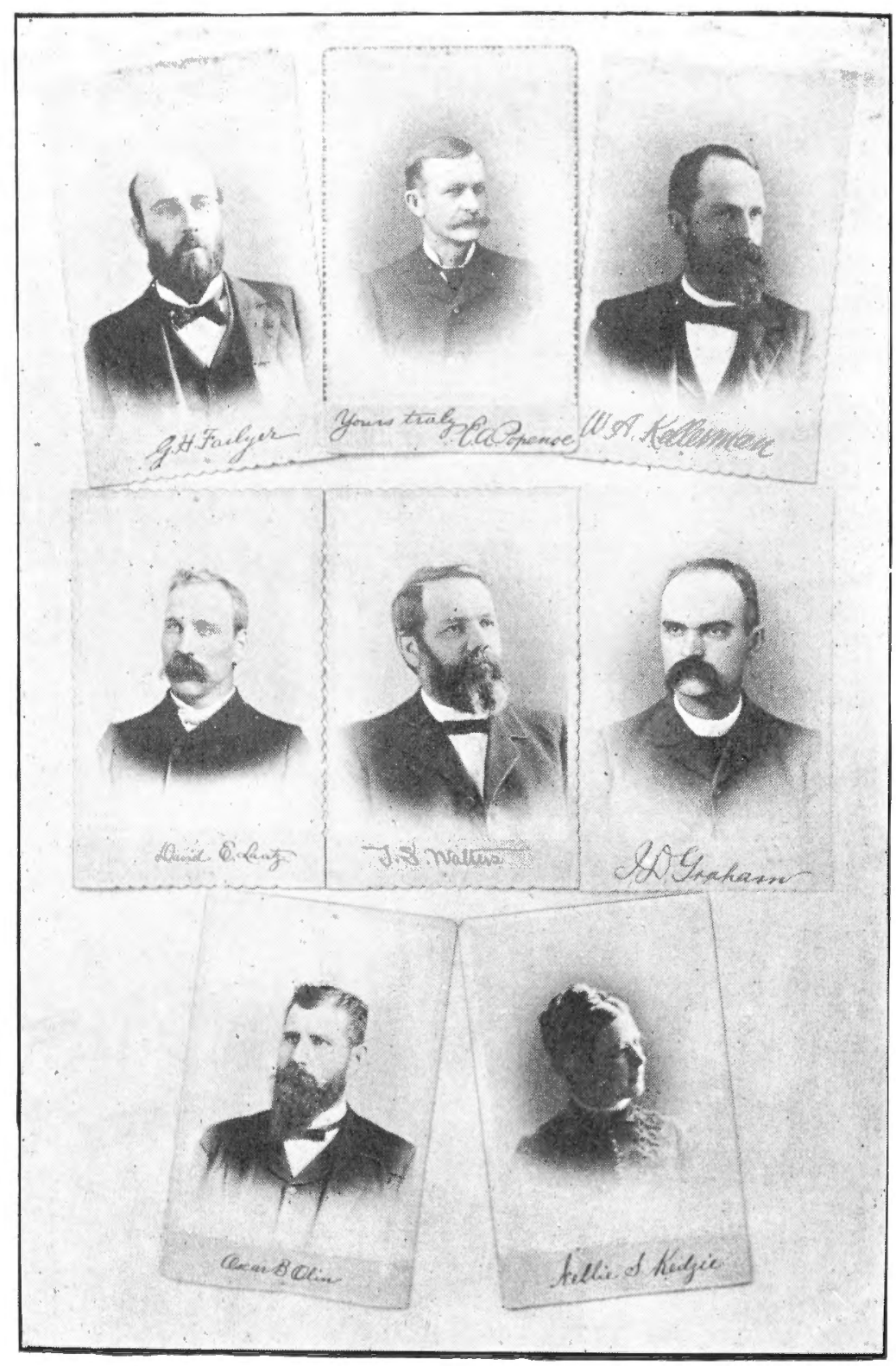




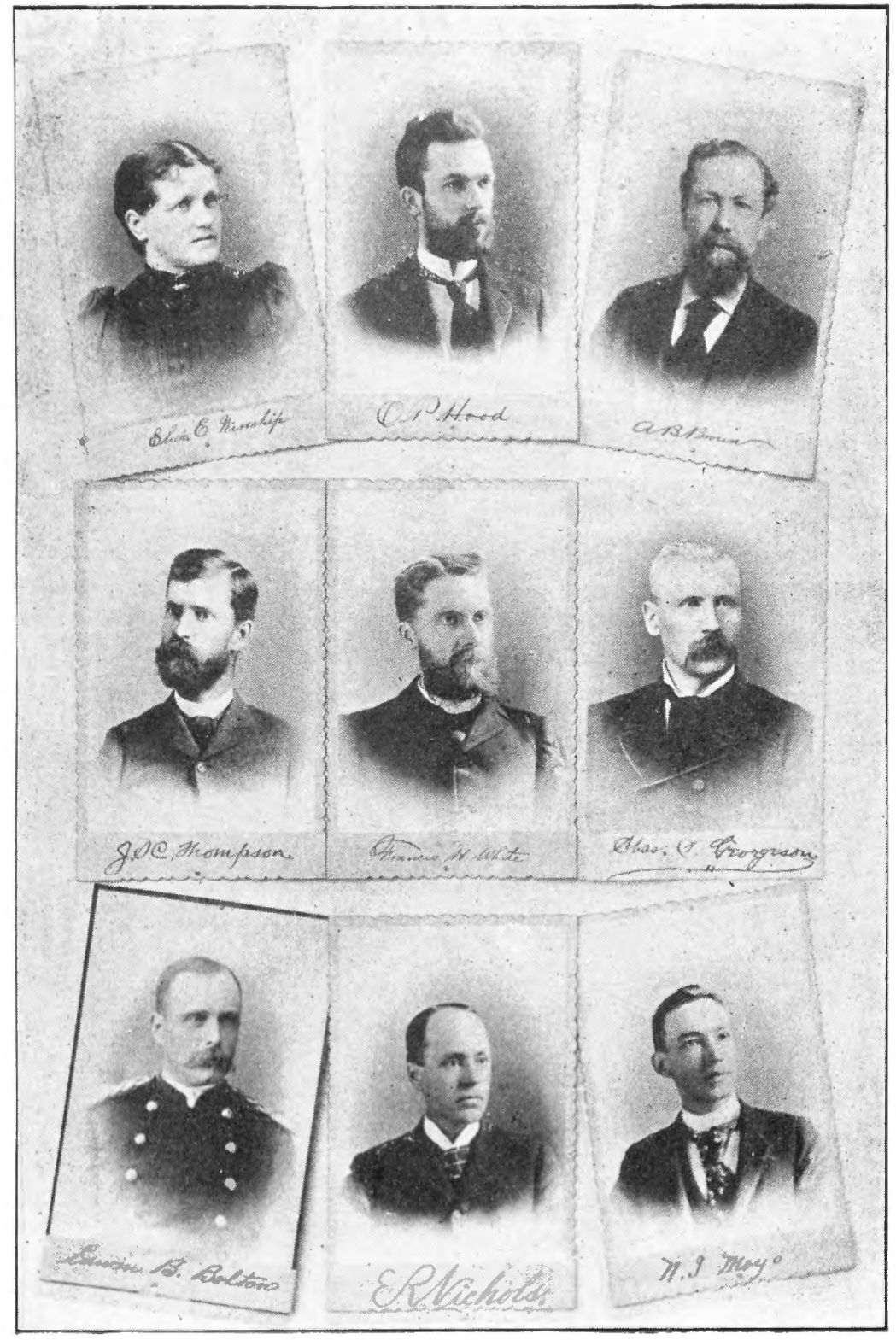





\section{FACULTY.}

George T. FAIRChild, A. M., President. *(1879),

Professor of Logic and Political Economy.

GEORGE H. FAILYER, M. Sc., (1878),

Professor of Chemistry and Mineralogy.

EDWIN A. POPENOE, A. M., (1879),

Professor of Horticulture and Entomology,

Superintendent of Orchards and Gardens.

WILliam A. KellermaN, Ph. D., (1883),

Professor of Botany.

DAVID E. LANTZ, M. Sc., (1883),

Professor of Mathematics, Librarian.

JOHN D. WALTERS, M. Sc., (1877),

Professor of Industrial Art and Designing.

IRA D. GRAHAM, B. Sc., (1879),

Secretary, Instructor in Book-Keeping.

OSCAR E. OLIN, (1885),

Professor of English Language and Literature.

Mrs. NELLIE S. KEDZIE, M. Sc., (1882),

Professor of Household Economy and Hygiene.

Mns. ELIDA E. WINCHIP, (1884),

Superintendent of Sewing.

OZNI P. HOOD, B. Sc., (1886),

Professor of Mechanics and Engineering.

Superintendent of Workshops.

ALEXANDER B. BROWN, A. M., (1886),

Professor of Music.

JOHN S. C. THOMPSON, (1887),

Superintendent of Printing.

FRANCIS H. WHITE, A. M., (1888),

Professor of History and Constitutional Law.

CHARLES C. GEORGESON, M. Sc., (1890),

Professor of Agriculture,

Superintendent of Farm.

EDWIN B. BOLTON, First Lieut. 23D U. S. Infantry, (1890),

Professor of Mılitary Science aud Tactics.

ERNEST R. NICHOLS, A. M., (1890),

Instructor in Physics,

Superintendent of Telegraphy.

NELSON S. MAYO, D. V. S., M. Sc., (1890),

Instructor in Physiology and Veterinary Science.

* Date of election. 


\section{ASSISTANTS AND FOREMEN.}

C. M. Breese, M. Sc., Assistant in Chemistry. Jennie C. Tunneld, B. Sc., Assistant Librarian. Wm. Baxter, Foreman of Greenhouse. W. L. House, Foreman of Carpenter Shop. C. A. Gundaher, Foreman of Blacksmith Shop. A. C. McCreary, Janitor. Julia R. Pearce, B. Sc., Clerk in Executive Office.

\section{STUDENT ASSISTANTS.}

Bertha H. Bacheller, B. Sc., Telegraphy. Francis C. Burtis, Agriculture. Geonge L. Clothien, Horticulture. Phil. S. Creager, Horticulture. E. Áda Littuk, B. Sc., Sewing and Music. Sam Van Blarcom, Horticulture. Frank A. Waugh, Horticulture. George W. Wildin, Carpentry.

ASSISTANTS IN EXPERIMENT STATION.

J. T. WIILARD, M. Sc., Chemistry.

S. C. Mason, B. Sc., Horticulture, Foreman of Gardens.

F. A. Marlatt, B. Sc., Entomology.

Emma A. Allen, B. Sc., Botany.

H. M. Co'tTReLi, M. Sc., Agriculture. Wy. Sheltox, Foreman of Farm. 


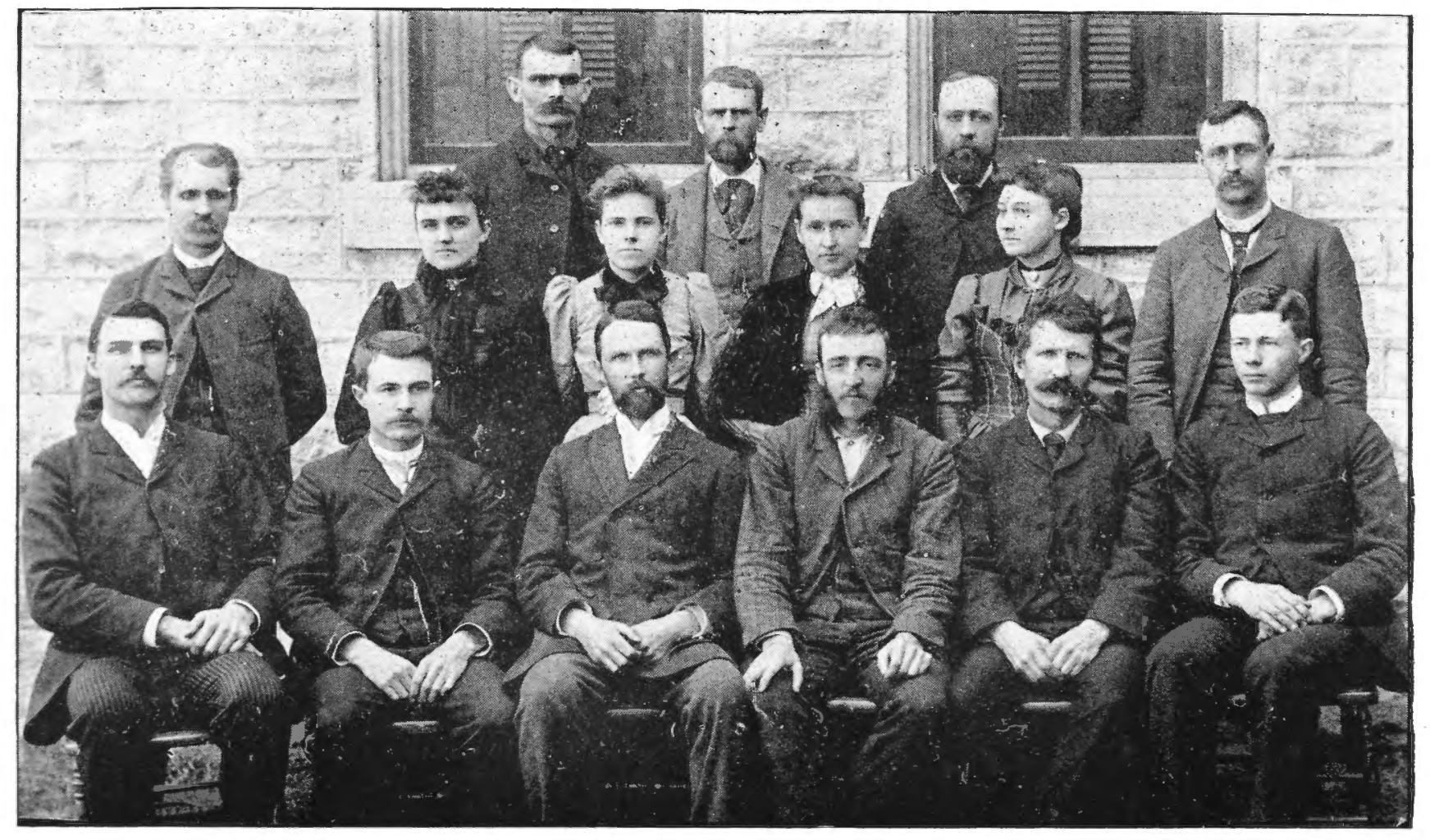

A. C. McCreary. W. L. House. C. A. Gundaker.

William Baxter. F. A. Marlatt.
Julia R. Pear
J. T. Willard.

\begin{abstract}
S. C. Mason.
\end{abstract}
H. Bda Little. H. M. Cottrell. Wm. Shelton.
C. M. Breese. W. T. Swingle. 



\section{BIOGRAPHIES OF THE PRESENT FACULTY.}

\section{G. H. FAILYER, M. Sc.}

George H. Failyer was born in December, 1849, on a farm in Mahaska county, Iowa. When he was six years old his father's family moved to Page county, Iowa, then on the extreme frontier, and settled on a preëmption claim.

He first attended school at the age of eight, and was regular in attendance, the schools ranging from three to six months in the year. He was student in Amity Academy, Amity, Iowa, for a term in 1867 and one in 1868. In April, 1868, he accompanied his father to Southeast Kansas, and took up a claim in connection with his father on the Cherokee Neutral Lands. From this time to September, 1873, he was engaged in the usual farm work of a new country, studying at odd times for recreation. In September, 1873, he entered the third year of the then six-year course at this College, and graduated in 1877, having found time during his course for special work in chemistry.

After graduation he spent a year resting on a farm in Chautauqua county, Kansas, and teaching in the common schools. A vacancy occurring in the chair of chemistry here in 1878 , he was asked to take the place temporarily, and at the close of the year was elected to the chair, which he still holds, having received the degree of Master of Science in 1879. From the necessities of the institution, the teaching of various other subjects has fallen to his lot, especially mineralogy, physics, meteorology and geology. In 1880 he spent a term in special study under Prof. R. C. Kedzie at the Michigan Agricultural College. He has been one of the chemists of the State Board of Agriculture since 1879; has been president of the Kansas Academy of Science, and is a member of the American Association for the Advancement of Science. At the organization of the State Experiment Station, he was made Chemist of the Station. $\mathrm{He}$ is the author of a bandbook for students in qualitative analysis, and the inventor of chemical apparatus and methods of some importance in quantitative analysis. 


\section{E. A. POPENOE, A. M.}

Edwin Alonzo Popenoe was born in 1853, on his father's farm in Montgomery county, Ohio, but studied in the common schools and in the village high school in McLean county, Illinois. Removing, in 1869, to Topeka, Kansas, he began in the following year a preparatory course in Washburn College, where he studied six years, graduating in the classical course in 1876 , and receiving the degree of Master of Arts from the same institution a few years later. After graduation, he taught a year in the Shawnee county schools, and a second as principal of the Quincy school in North Topeka, resigning the latter position in 1879 to accept the chair of Botany and Horticulture in the Kansas State Agricultural College, where his duties included the instruction of the classes in zoölogy and entomology, and the superintendence of the orchards, gardens and grounds. At the division of duties in 1883, he was assigned to the chair of Horticulture and Entomology, which he still occupies. $\mathrm{He}$ is a member of the American Ornithologist's Union, a life member in the Kansas State Horticultural Society and in the American Pomological Society, the vice-president for Kansas in the American Forestry Association, and secretary of the American Horticultural Society. He was for many years secretary of the Kansas Academy of Science, and is one of the official entomologists to the State Board of Agriculture.

W. A. Kellerman, Ph. D.

William A. Kellerman was born May 1st, 1850, in Central Ohio; his early life being spent upon his father's farm. He prepared for college in Fairfield Academy. In 1871 he entered Cornell University, and after four years graduated with the degree of B. Sc. After graduating he became Professor of Natural Science in the Wisconsin State Normal School. After five years' continuous service in that position he went to Europe and studied two years in Germany and Switzerland, and received the degree of $\mathrm{Ph}$. D. In 1881 be returned to this country and was called to the Kentucky State Agricultural and Mechanical College, where he remained two years. He has been connected with the Kansas State Agricultural College since 1883, as Professor of Botany and Zoölogy, until 1888, since that time of Botany alone. In 1885 he was 
made Botanist to the Kansas State Board of Agriculture, and in 1888 to the Kansas Experiment Station. In connection with his work he has published "Elements of Botany," "Plant Analysis," "Analytical Flora of Kansas," and various scientific contributions. In 1885 he established the "Journal of Mycology" and edited the same until 1889.

\section{E. LANTZ, M. Sc.}

David Ernest Lantz, Professor of Mathematics, and librarian, was born in Juniata county, Pennsylvania, in 1850 . He was educated in the Juniata county Normal school, and in the State Normal school at Bloomsburg, Pennsylvania, graduating in 1875 , and received the degree of Master of Science, after examination, in June, 1885.

From 1870 to 1883 he was a teacher in the public schools, and holds life diplomas in both Pennsylvania and Kansas. For two years he was principal of public schools at Mifflintown, Pennsylvania, and of the Juniata county Normal school, and for five years previous to election to his present position he was superintendent of schools at Manhattan, Kansas. "He is well known through the State as a successful conductor of teachers' institutes, and in 1882 was nominated by acclamation in the Democratic convention for State superintendent of public instruction. $\mathrm{He}$ is an bonorary member of the Kansas State Horticultural Society, a member of the Kansas Academy of Science, and an associate member of the American Ornithologists' Union.

\section{J. D. WALTERS, M. Sc.}

Professor John Daniel Walters was born in 1848 , and is a native of the canton of Solothurn, or Soleure, in Western Switzerland. He received his education in the common schools of Aetigkofen and Dombresson; in the high school of the county of Bucheggberg, and the cantonal gymnasium of Solothurn, from which institution he graduated in 1867. Two months after his graduation he landed in New York, working as decorative painter, architectural draughtsman and private teacher in different parts of the country, until his appointment to the position of teacher of drawing at this College. He was given the degree of M. Sc. in 1883, and made Professor of the department of Industrial Art and Designing in 1885. The Professor has taken considerable interest in the work of the $\mathrm{Na}$ - 
tional Educational Association. During the meeting of the Association in 'Topeka, in 1886, he was the secretary protem., and at the meeting in the following year, in Chicago, the regular secretary of the Industrial Section. At the meeting in Nashville in 1889, he read a paper on industrial education, and served on two different committees. He has also read papers before many of the different scientific or practical societies of the State, and has been for several years the chairman of the standing committee on landscape gardening in the State Horticultural Society.

I. D. GRAHAM, B. Sc.

Ira D. Graham was born in Vinton, Iowa, on August 29, 1856. Two years later his parents removed to Knox county, Illinois, where he grew up. He received the usual common school training and entered Abingdon College, Abingdon, Ill., at the age of sixteen years, and paid his way while there by manual labor. From this college he received the degree of Bachelor of Science, and in 1885 the honorary degree of Master of Arts from Eureka College, Eureka, Ill.

After leaving college, he served several years as a telegraph operator and railroad agent, and taught several terms in the common schools of Illinois and Kansas. In 1879 he was elected superintendent of telegraphy in the Kansas State Agricultural College, and held this position until 1890. He was elected secretary of the faculty in 1881, and in 1884, when the office of assistant secretary of the Board of Regents was created, Mr. Graham was appointed thereto. In $1886^{\circ}$ he was made instructor in book-keeping and commercial law, and in 1890 secretary of the Experiment Station. He was for several years treasurer of the Kansas Academy of Science, was one of the founders of the Kansas Dairy Association, and has been its treasurer and a member of its executive board for the past two years. $\mathrm{He}$ is a member of the Kansas State Grange and the Kansas State Historical Society, and of various other associations, educational and scientific.

\section{O. E. OLIN,}

O. E. Olin was born at Earlville, Ohio, on the äd of December, 18j1. His father was a prosperous farmer of the western reserve. The family, leaving the ancestral home, went west in 1852. $\mathrm{Mr}$. 
Olin began his education in the schools of Towa and California, and returning, completed his school days in the public school of his birthplace. He began teaching in Michigan, in 1870. In 1871 he came to Kansas, and has been working in the schools of this State ever since. He first taught a country school in Osage county, was then principal of the Baldwin city schools, afterward principal of the Augusta school in Butler county, and superintendent of schools in El Dorado. From the last position he was elected to the professorship of English in the Agricultural College.

Mrs. NELLIE s. KEDZIE, M. Sc.

Mrs. Nellie Sawyer Kedzie was born in Madison, Maine, August 2, 1858. The first eighteen years of her life were spent in the country, as her father was a farmer.

Her education was begun in village and country schools. In 1870, her family moved to Ottawa, Kansas, where she attended a private school taught by Prof. and Mrs. M. L. Ward. She spent two years in the Kansas State Agricultural College, graduating with the class of 1876 . After teaching one year in a country school, she was employed four years as one of the teachers in the graded schools of Ottawa.

She married Robert F. Kedzie, Professor of Chemistry in the Mississippi Agricultural College. After his death, in 1882, she returned to Kansas, and was employed as teacher of Domestic Economy in this institution. The next year the College gave her the degree of M. Sc., and in 1887 made her professor of Household Economy and Hygiene.

Mrs. ELIDA E. WINCHIP.

Mrs. Elida E. Numan Winchip was born in Warren county, New York, September 23, 1849. She attended school at the Glens Falls Academy, with a special course in painting and drawing. She moved to Topeka, Kansas, in 1872, and taught painting and drawing in Bethany College for three years. In 1869 she was married to Jesse K. Winchip, and they moved to Manhattan, Kansas, in 1872. After the death of Mr. Winchip, Mrs. Winchip was appointed superintendent of sewing at this College. Her work here has brought under her instruction, during the past seven years, nearly a thousand young women of Kansas. 
O. P. HOOD, B. Sc.

The present head of the Mechanical Department, Prof. O. P. Hood, was born at Lowell, Mass., June 14, 1865, but from 1869 until 1885 his home was Indianapolis, Indiana. He supplemented his early mechanical training by one year of study at Worcester Technological Institute, Worcester, Mass., and two years at Rose Polytechnic, Terre Haute, Indiana, graduating in the first class from that institution with the degree of B. Sc. in the Mechanical Engineering course. Early training in a shop devoted to pattern and model making was further extended after graduation by journeyman work at that trade in Chicago and Indianapolis.

After some experience as superintendent of a company making surgeons' specialties, he was, in 1886, upon recommendation of professors at Rose Polytechnic, selected for superintendent of the Mechanical department of this College. He was made instructor in mechanics and engineering in 1887 , and professor in 1889 , still retaining the duties of superintendent of shops.

\section{A. B. BROWN, A. M.}

Alexander B. Brown, A. M., of the chair of Music, is a native of Edinburgh, Scotland. He was a student in Oberlin College and leader of the college orchestra and band at the opening of the rebellion, when he and a majority of the band volunteered, and were accepted for service, in conjunction with company "C", afterwards mustered into the 7th Regiment Ohio Infantry at Cleveland, Ohio, where he was detailed by Col. E. B. Tyler to recruit a band for the regiment and brigade. After receiving honorable discharge from the army at Washington, D. C., he pursued his musical studies in Boston, graduating from the Boston Music School with honorable mention, especially as a vocalist. After an extended trip through New England in the interests of inusic, being urgently solicited to accept the professorship of music and elocution in Olivet College, Michigan, he did so, and afterwards finished his literary course in that institution. He was elected associate editor of The Olio and Folio, a literary and musical journal. $\mathrm{He}$ organized the Michigan Conservatory of Music and Elocution, in connection with the college, and after serving it as director for ten years, he resigned, to accompany the 
ex-president of the college, Rev. N. J. Morrison, D. D., and the local trustee, Hon. S. F. Drury, to Springfield, Missouri, where he assisted in the founding of Drury College and the Missouri Conservatory of Music and Elocution.

For the purpose of completing the prismatic charts, in association with his brother, president of the Kansas Conservatory, he removed with his family to Leavenworth in 1881, resigning his professorship in Drury and directorshp in the conservatory and becoming the director of the Kansas Conservatory. In 1883, the charts being nearly completed, he accepted a seccnd call to Drury College and Missouri Conservatory, where he remained until 1886, when he again resigned, and accepted a call to the State Agricultural College.

\section{J. S. C. THOMPSON.}

J. S. C. Thompson, Superintendent of Printing, was born at Scottville, Illinois, December 7, 1858. He early learned the printer's trade, spending all vacations and spare hours from school in the office, until, at the age of eighteen years, he left school and devoted all his time to mastering the intricacies of the "art preservative." To his typographical labors were added the duties of local writer, in which dual capacity he has since acted for the greater part of the time. When twenty years old, Mr. Thompson heeded the lamented Greeley's injunction and "went west" as far as Marshall, Mo., where he was engaged for two years on the Marshall Daily Neros. In August, 1881, be went to Stockton, Kansas, where he remained for a year on the Record, thence going to Atchison, where he spent a short time with the Haskell Printing Company. While bere he was called to Newton to take a position on the Nevton Daily Republican, then the property and under the management of Hon. Allen B. Lemmon. After four years' service as city editor of the Republican, Mr. Thompson was elected, in January, 1887, to the position he now holds.

F. H. WHITE, A. M.

Francis Harding White, Professor of History and Constitutional Law, was born in Attica, New York, 1862. His education, commenced in common school, included two years at the Collegiate Institute, Attica, New York. After practicing printing and telegraphy for several years, he entered the United States signal 
service in 1880; studied meteorology, electricity, etc., at Fort Meyers, and served for three years in the chief office of the signal service at Washington, D. C. During his stay there he prepared, under private tutors, for Princeton University, and graduated from that institution in 1887 , with special honors in political science, and received, after competitive examination, the historical fellowship. The next year was spent as superintendent of the Brooklyn Children's Aid Society, which provides industrial schools, assistance of different kinds, and homes for thousands of children. He was called to the chair of History and Constitutional Law at this College in 1888, and made professor in the following year. He received the degree of A. M. from Princeton in 1890.

C. C. GEORGESON, M. Sc.

Charles Christian Georgeson was born June 26th, 1851, on the island of Langeland, Denmark. He attended private and public schools during his boyhood, and from 1867 to 1872 served a five years' apprenticeship in horticulture. Having emigrated to America in 1873 he graduated from Michigan Agricultural College in 1878 with the degree of B. Sc., receiving M. Sc. from the same institution in 1882. From graduation to 1880 he was associate editor of the Rural New Yorker, New York City, and was then appointed Professor of Agriculture in the Agricultural and Mechanical College of Texas, where he remained several years. From the beginning of 1886 to near the close of 1889 he was in the employ of the Japanese government, as Professor of Agriculture, in the Imperial College of Agriculture and Dendrology in Tokio, Japan, and on his return to this country was appointed Professor of Agriculture and superintendent of the farm, at the Kansas State Agricultural College.

E. B. BOLTON, 1sT LIEUT. 23D INFAN'TRY.

Edwin B. Bolton, 1st Lieutenant 23d Infantry, U. S. Army, was born and raised in Mississippi. He was a cadet at the Military Academy, West Point, New York, from July, 1871, to June, 1875, when he graduated and was appointed $2 \mathrm{~d}$ Lieutenant $23 \mathrm{~d}$ Infantry. He was with his company on frontier service till November, 1879; was on detached service as Professor of Military Science and Tactics at the Mississippi Military Institute, Pass Christian, Mississippi, and at the Agricultural and Mechanical College of Mississippi, 
Starkville, Mississippi, to March 1883, when he again joined his company for duty on the frontier. He was promoted 1st Lieutenant in February, 1884, and was Regimental Adjutant 23d Infantry from April, 1886, to April, 1889. At the expiration of the maximum limitation of four years' service in that capacity he served in command of company until August, 1890, when he was detailed as Professor of Military Science and Tactics at the Kansas State Agricultural College.

E. R. NICHOLS, A. M.

Ernest R. Nichols was born in Farmington, Hartford county, Connecticut. His parents soon moved to a farm in northeastern Iowa, where his time was spent, till the age of eighteen, working on the farm summers and attending the district school winters. In the summer of 1878 , he taught his first term of district school, and the following winter a second term. During the year 1879 and a part of 1880 , he was a student at the Iowa State normal school. After being principal of schools at the village of Luana for a year, he completed the course at the State normal school, graduating with the degree Bachelor of Didactics. After a year's service as principal of Charles City high school, and another year as superintendent of Nashua schools, he entered the State University of Iowa as a student, devoting most of three years to mathematics and the physical sciences, graduating in 1887 with the degree Bachelor of Science, and receiving in 1890 the degree Master of Arts. Having been elected, in 1887, superintendent of Monticello schools, he resigned after eight days to accept the assistant professorship of mathematics in the State University of Iowa, which position he held until 1890, when he resigned to accept his present position.

\section{NELSON S. MAYO, D. V. S.}

Nelson S. Mayo was born near Battle Creek, Michigan, in 1866, and worked upon the home farm until he entered the Michigan Agricultural College with the class of 1888 . Upon graduating he was appointed assistant to the veterinarian of the Michigan Experiment Station. He completed the course at the Chicago Veterinary College, graduating with honors in 1889 , and was a special student in bacteriology under Dr. F. S. Billings. He returned directly to the Michigan Agricultural College, where he assisted in the Experiment Station, and practiced his profession. In 1890 he took the Master's degree, and in October was called to his present position, the chair of Physiology and Veterinary Science. 


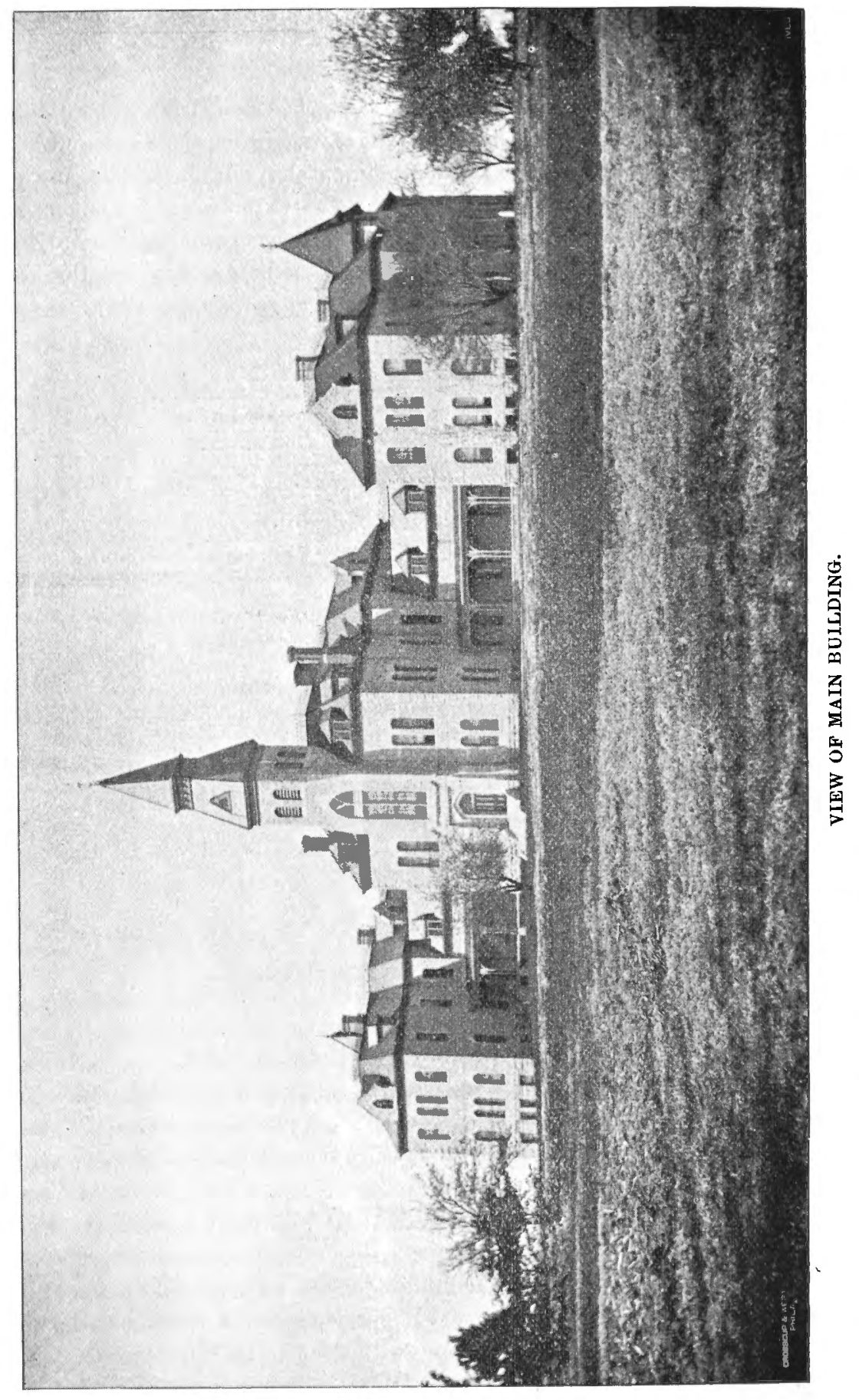




\section{ALUMNI.}

Edgar A. Allen, '87, was born in Iowa in 1866. Since completing his course, he has been engaged in teaching, and has been employed as instructor in county normal institutes several times. At present he is practicing law in Blue Mound, Kansas.

Emma A. Allen, '89, was born in Indiana in 1869. Since graduation, she has been teaching near Manhattan, and is now assistant botanist to the Experiment Station at this College.

Chester J. Allen, '82, was born in Iowa in 1860. He died in 1885.

Emmett S. Andress was born in the Hoosier State, July 8, 1866. Since graduating, in 1884, he has been employed in stock raising near Lakin, Kansas.

Grant Arnold, '88, was born in Kansas in 1866. He has followed the occupations of commercial traveling and school teaching, and is engaged in the latter at Toledo, Washington.

Fred H. Avery, who began his existence at Wakefield, Kansas, in 1866, was awarded a diploma at the K. S. A. C. in 1887. In the succeeding years he has had experience in the mercantile world in Western Kansas, and in his present occupation of farming at Wakefield, Kansas. In April, 1889, he married Miss Hattie McConnell, of Menoken, Kansas.

Bertha Helena Bacheller was born at Norwich, New York, in September, 1866. She received the degree of B. Sc. in ' 88 , and has been teaching and pursuing a post-graduate course in chemistry and household economy at her alma mater since, and is thus engaged at the present time.

Thomas Bassler, '85, was born in Pennsylvania, March 21, 1859. He has been engaged in teaching and horticulture since graduation, and is now located at Louisiana, Missouri, in the nursery business. He was married August 12, 1886, to Miss Linna Snyder.

Joseph W. Bayles, of Manhattan, Kan., was born September 15, 1868, in Alleghany county, $\mathrm{Pa}$. After graduating in 1889, he attended the Ottawa University for a time, and has since been employed as a farmer and school teacher.

Augustine Beacham, a native of England, was born February 17, 1857. He received his sheepskin from this College in '80, and in 1884 graduited from the Northern Indiana Normal School, receiving the degree of A. B. He taught school for two years and studied law the following two, being admitted to the bar in 1888. He is at present a government employe at Seattle, Wash. 
James W. Benry, '83, was born in Pennsylvania in 1858. He has been variously engaged as a farmer, a carpenter and a contractor ever since his graduation. He is located at Jewell City, Kan. His wife, formerly Hattie L. Peck, is also a graduate of the K. S. A. C.

Ar'inur T. Blarn was born in Kansas in the year 1860 . He graduated from the Kansas Agricultural College in 1879. May 7, 1883, he married Miss Etta Camplell. For a while he clerked in E. B. Purcell's bank, but afterwards went into the grocery business. At present he is living at Duarte, California.

S. I. Bonton, '90, was born in Ohio in 1867. Since graduating he has been farming near Hill Top, Kansas.

Mary C. Bower was born at Manhattan, Kansas, September 26, 1863. She has been employed as clerk in Manhattan since graduating with the class of '83.

Claude M. Breese was born on a farm near Mount Gilead, Ohio, October 7,1865 . When three years of age his parent, moved to that city, his father having been elected county auditor. When twelve years old, his parents moved to a farm near Elmdale, Kansas, where he lived and worked till he entered this College, in the fall term of 1884 . He graduated in '87, and in the same year was appointed assistant chemist, which office he still holds. He was married to Miss Julia L. Shipman, of Elmdale, Kansas, December 27,1887 .

Lillie B. Bridgman, '86, was born at Atchison, Kansas, in 1867. She has taken a course in elocution since completing the course here, the remainder of the time having been employed in teaching in the Argentine, Kansis, schools, where she now is.

Frorence J. Brous, of '84, was born in Kansas, in 1863. She attended a stenographic and typewriting institute at Kansas City, Mo., and is now a teacher in Kansas City, Kansas; address, 828 Packard street.

Harry A. Brous, of "r4, was born in Pennsylvania, July 20,1851. He graduated from the medical college at Jefferson, Mo., and is now practicing at 521 Pine Street, Philadelphia, Pa.

Lours P. Brous, '86, was born March 27, 1866, at Manhattan, Kansas. He worked for a time as an architect, and is now a topographical engineer for the L, \& E. Railroad Company, at Eugene, Oregon.

John B. Brown began his eurthly career at Osceola, Iowa, November 28,1865 . The commencement exercises of June, '87, satisfactorily severed his connections with the K. S. A. C. as far as student life is concerned. For three years succeeding that time he taught in the public schools, one year holding the principalship of Lincoln schools, in Fredonia, Kansas. In the latter part of 1890 he entered the U. S. signal service, and as an assistant observer has done duty at Lenvenworth and Wichita, Kansas, St. Louis, Mo., and at his present station, Nashville, Tenn. 
Walter R. Browning was born in Kansas, in 1867. He graduated in '89, and since has been working as a civil engineer, in the employ of the Union Pacific Railroad.

Bartholomew Buchi, '84, was born in Versaw, Switzerland, August 24, 1862. After receiving his degree at this College, he entered the Iowa Agricultural College as a special student, and graduated with the degree of D. V.S. He is at present teaching in the Alma, Kansas, schools.

David E. Bundy, '89, was born in Iowa in 1862. Since graduation he has been engaged in teaching, having spent some time as instructor in the Ponca Indian School. $\mathrm{He}$ is now engaged in farming near Blue Rapids, Kansus. In the fall of 1890 , he was married to Miss Cora Waldraven, of Parallel.

Walter J. G. Bun'ris, a farmer and fruit grower of Fredonia, Kansas, was born at Saratoga Springs, New York, April 3d, 1865. Before entering his present occupation he was employed as a teacher. On December 9th, 1890 , he was married to Winifred Brown, a third-year student in '87.

Lewis W. CaLL, '83, was born in Ohio in 1859. He is at present located in Washington, D. C., being employed in the Attorney General's office.

John H. Calvin, '84, was born in Iowa in 1860. After graduating he studied law, was admitted to the bar and is now practicing at Topeka, Kansas, being associated with W. H. Cowles, formerly a professor at this College. In 1886, he was married to F. Henrietta Willard, '86.

Emily M. Campbell Robinson, "71, died in 1877.

EtTa Campbell Blain, 79, was born at Duquoin, Ill., March 28, 1861. In 188:3, she was married to Arthur T. Blain, and at present resides in Duarte, California.

Frank A. Campbell, '90, was born in Illinois, October 22, 1867. On July 4, 1890, he was married to Miss Alma Wiley, and removed to Highland, Colo., where he is now employed as newspaper reporter.

Mark A. Carleton, was born in Monroe county, Ohio, in 1860, and spent the first ten years of his life in that country. In 1876, he removed with his parents to Cloud county, Kansas, where they engaged in farming. He entered the Sophomore class at the K. S. A. C. in 1883, intending to complete the course in three years, but afterward concluded to add a course in natural history to the regular studies and graduate with the class of '87. During the summer of 1885 he was one of the party sent out by the College to collect botanical and geological specimens in Western Kansas. While in college he took a great interest in all scientific subjects, was an active member of the Scientitic Club, and has been a member of the Kansas Academy of Science for the past five years. He was called to his present position, Instructor in Natural History and Curator of Museums, at Garfield University, Wichita, Kunsas, in 1888 . 
Ella S. ChILD, '77, was born in Kansas in 1856. She is now teaching in the Manhattan city schools.

C. G. Clarke, '88, was born in New York in 1867. Since graduation he has been, in succession, a student in Washburn College, at Topeka, instructor in a college at Erie, Pa., and student in Yale College. He is now at New Haven, Conn., in attendance at the last named school.

Edgar F. Clark, '74, was born in Circleville, Ohio. He taught in Manhattan for some time, and is now practicing law at Ellsworth, Kansas, In 1886 he was married to Miss Elizabeth Emerson.

A. C. Совв, '88, was born in Tennessee in October, 1864. He has followed his chosen trade, carpentry, ever since graduation, and is now located at Wagoner, Indian Territory. He was married in 1887 to Miss Lucy Van Zile, of (arthage, Ill.

Mattie Coвs was born in Tennessee in 1862. Since graduating in '88, she has been instructor in Lester Seminary at Holden, Missouri, and is at present a teacher at Wagoner, Indian Territory.

Samuel S. Cobb, '89, was born in Tennessee in 1865. He has occupied most of his time since graduation as printer, but is now in the drug business at Wagoner, Indian Territory. He has been postmaster at Wagoner for some time.

WM. A. CoRey, ' 84 , was born in Kansas in 1862. Since graduation he has been engaged in teaching, and is now located at Salt Lake City, Utah.

H. M. CotTrelL, born July 29, 1863, in Mendon, Ill; removed to Wabaunsee, Kansas, in 1875; entered the Kansas Agricultural College in 1880, and graduated in 1884, taking in addition to the regular course a special course in chemistry; went to farming immediately after graduating. Married March 4, 1887, to Fannie M. Dorman, a student of the Agricultural College. Took post-graduate course in agriculture and agricultural chemistry in the Kansas Agricultural College, taking degree of Master of Science in 1887. February, 1888, appointed assistant in agriculture at the Kansas Experiment Station. Always worked on a farm when not at school.

Neluie E. Cottrell Stiles, '87, was born at Mendon, Illinois, September 22, 1865. On June 30,1887 , she was married to Charles H. Stiles, and now resides at Pavilion, Kansas.

Minnie H. Cowell, '88, was born in England in 1866. After completing her course, she returned to England, and is now employed as a hospital nurse in London.

Lizzie R. Cox Kregar was born in Clay county, Indiana, August 18, 1860. After graduating in ' 80 , she taught school for six years, the last term being in Milford High School. On June 3, 1886, she was married to J. R. Kregar, who is at present a stock dealer at Milford, Kansas. 
IDA CRANFord Sloan was born in the State of Illinois in 1859. After graduating in ' 82 she was married to J. A. Sloan of the same class, and is at present a housewife in California.

Arthur F. Cranston, '90, was born in Illinois in 1867 . He is at present studying law at his old home, Parsons, Kansas.

EDWard V. Cripps, '82, was born in New York in 1859. He is at present a teacher of elocution, in Boston, Mass.

Jubson H. Criswell was born in Newton, Hamilton county, Pa., in July 1866. He completed the college course with the class of '89, and is now a prosperous furmer, living near Manhuttan.

Eliza Z. Davis Stringfield, of Pomona, Cal., is a native of Indiana, having been born in Fountain county in 1849. She graduated with the class of '73, with only two in the class. In 1876 she was married to J. W. Stringfield.

JoHn Davis, '90, was born in Wolcott, Ind., in March, 1867. Since graduation he has been teaching near Manhattan, but is now on an extended visit to his birthplace.

JoHN E. DAvis, '74, was born in 1855. After graduation he studied dental surgery, receiving the degree of D. D. S., and is now practicing his chosen profession at Oakland, Cal.

Henry L. Denison, ' 67 , was for a time stenographer and clerk of the U. S. Court at Denver, Colo., and is now secretary of the Gulf Improvement Co., at Galveston, Texas.

EILA F. Derison Whedon, '71, is married to Chas. O. Whedon, "71, and resides at Lincoln, $\mathrm{Neb}$.

AlBert Deitz, '85, was born in Leavenworth, Kansas, November 11, 1863. Since graduation he has been engaged as a teacher, as a cement manufacturer, as a general contractor and as a grocer. $\mathrm{He}$ is now at Kansas City, Mo., in the grocery business.

Grant W. Dewex, '90, was born in Mound City, Linn county, Kansas, 1870. A short time after graduating he became assistant photographer to his father at Manhattan, Kansas, where he now is.

Lrman H. Dixon, '88, was born in New London, Conn., November 19, 1866. $\mathrm{He}$ has been engaged most of the time since graduating as draughtsman, being located at present at Bent Cañon, Colo.

Charles J. DobBs, '90, is a native of England, having been born at Middlesbro-on-Tees, in 1868. He has been engaged in teaching and the study of law at Rossville, Kansas, but is now in the offlce of the county attorney at Topeka. 
Carrie F. Donaldon Brown, '84, was born in Illinois in 1863 . She was variously engaged as school teacher and assistant librarian at the $K$. S. A. C. until August, 1887, when she was married to George Brown. Until recently she has been located in Wallace, Kausas, but is now in Colorado.

Flora Donaldson Reed, '81, was born in Illinois. She was engaged in teaching until her marriage with Corvin J. Reed, of St. Clere, in 1882.

Florence A. Donaldson, '84, died in August, 1888.

Frank W. Dunn, '84, was born in Ohio, in 1859. Shortly after graduating, he married a Miss Baker, of Manhattan, and later removed to New Castle, Colo., where he is engaged in farming.

Charles W. Earle was born at Manhattan, Kansas, in 1870. After graduating in ' 90 he went to Denver, Colo., where he has been employed as an advertising clerk for a business house. His present address is 235 Thirty-First avenue, Denver, Colo.

W. K. Eckman first saw the light at Waterford, Ohio, nn March 15,1858. He graduated with the class of ' 79 , and since that time has been engaged in the various occupations of farming, book-keeping, printing and lumber dealing, the last being his business at the present date. In 1884 he was married to Lizzie Woodruff, and they now reside at 1139 Kearney street, Atchison, Kas.

Albert R. ElliotT, of the class of '87, was born November 15, 1868, at Atchison, Kansas. Since graduation he has been employed as a ranchman and logger at Nederland, Colo.

Frederick B. ElliotT, insurance and real estate agent, of Manhattan, was born March 27, 1866, at German, New York. He graduated with the class of ' 87 .

George H. Failyen, M. Sc., Manhattan, Kansas. Professor of Chemistry in Kansas State Agricultural College. (See Facultr.)

David G. FAIRchild was born on the Michigan Agricultural College grounds, in 1869 , and spent the first ten years of his life there. He moved with his parents to Manhattan, Kansas, in 1879 , his father becoming president of this College. He lived here till after graduating with the class of ' 88 , when he removed to Iowa to study botany with his uncle, Dr. B. D. Halstead, who soon after removed to Rutger's College, New Brunswick, New Jersey, and Mr. Fairchild accompanied him to continue his specialty in the line of botany. In July of 1889 he accepted a position in the Department of Agriculture, at Washington. He is at present investigating the diseases of nursery stock, at Geneva, New York.

Paul H. Fairchild, '86, was born at Lansing, Mich., June 21, 1867. After graduating he was engaged in railroad engineering in Southern Kansas, and in mechanical draughting. He afterwards attended the medical college at Columbus, Ohio, and Bellevue Hospital Medical College, in New York. He is now a practicing physician, located at 155 Hancock street, Brooklyn, N. Y. 
Mattie I. Farley Carr, '89, was born in Iowa, in 1865 . She has been engaged in teaching most of the time since graduation, both in Kansas and in Washington. She was inarried April 10, 1891, to Henry Carr, of Ruby, Wash., where she now resides.

Clarence E. Freeman, '89, is an unmarried principal of Shorey Schools, in North Topeka, Kansas. After graduating at the K. S. A. C., he completed the Euglish course at the State Normal School. For nearly twenty-four years he has been a native of Hazelton, Indiana.

Carl E. Friend, of the class of '88, was born in Michigan in 1869. He is now engaged as a lumber merchant, in Ontario, Kansas.

Élla M. Galk Kedzie was born in Pavilion, Illinois, July 26, 1856. In 1867 her family moved to Manhattan, where her father was pastor of the Baptist church, and afterward Professor of Horticulture at this College. The public schools of Manhattan prepared her for entering this College, from which she graduated in 1876. She married Wm. K. Kedzie, Professor of Chemistry here, who afterward occupied the ame chair in Oberlin College. After the death of her husband, she was employed as teacher of painting and drawing, in Olivet College, Michigan, where she now resides with her two children.

Gronge A. GALE, "76, was born in Vermont in 1854 . He is at present engaged in fruit growing at Lake Worth, Florida.

Hattre L. GALE Sanders, '89, was born at Manhattan, Kansas, January 20, 1871. In September, 1890, she was married to $W$. H. Sanders, '90, and now resides at Lake Worth, Florida.

IRA D. Gardiner, of the class of '84, began his life near Jefferson City, Mo., on the eighty-tifth anniversary of our national independence. After yraduating, for two years he tilled the soil, but later entered the editorial urena, and is now editor of the Alma News, published at Alma, Kansas. In 1887 he was married to Ida H. Quinby, '86, of Wakefield, Kansas.

W. D. Gilbert, '74, was born in 1848. He is now located at Atchison, Kansas, where he is practicing law.

Emma E. Glossor, '83, was born in Kansas in 1862. She is now employed as teacher in the Manhattan city schools.

Albert N. Godfrex, M. Sc., is a native of Iowa, and was born in 1855 . He received his degree of $B$. Sc., in 1878. After graduating he continued a post-graduate course. He is now engaged in raising fruit and farming at Madison, Kansas.

AbBote M. Green, of the class of '86, was born in Ohio in 1865. Since graduating he has been a teacher, and is at present a civil engineer at Santa Barbara, Cal.

John S. Griffina, "77, was born in Kansas in 1855. He is now a merchant at Topeka, Kansas. 
William J. Griffing was born at Topeka, Kansas, Nov. 24th, 1860. He graduated in '83, and the following year was joined in marriage with Hattie P. Clark. Since then he has been a practical representative of this institution as a farmer and fruit grower near Manhattan, Kansas.

Belle M. Haines Pond, '67, was born at Leesburg, Ohio, August 20tb, 1842. She taught school for a short time, and on the 26th of June, 1873, was married to M. A. Pond, and is now living in Topeka, Kansas.

Exma L. Haines Bowen, of Manhattan, Kansas, was born at Greenfield, Ohio, March 18, 1849. She was one of the first graduates from this institution, completing the course in 1867. She was engaged in teaching for a time, and in 1872 was married to Wm. G. Bowen.

Proced E. Haines, '83, was born in Riley county, Kansas, in 1860. Since graduating she has been teaching and pursuing a post-graduate course at this college. She is at present instructor in art in the New Mexico Agricultural College, at Las Cruces, N. M.

Theophania M. Haines Huntington was born at Greensville, Ohio, MLay 7, 1854. After she graduated, in '72, she taught school till her marriage with Joseph A. Huntington, May 20, 1877. January 24, 1880, she died at Denver, Colorado.

J. G. Harbord was born in Bloomington, Illinois, March 21, 1866. He lived in Illinois till 1870 , when his parents moved to Missouri, where he resided until 1878, when his family came to Agnes City, Kansas. From seven to sixteen, he attended the common schools of Missouri and Kansas, except in 1877-8-9. when he was a pupil in the city schools of Bloomington, llinois. He entered the College September 14, 1882, and graduated June 9, 1886. From September, 1886, to May, 1887, he was assistant principal in. the schools of Leon, Kansas. In June, 1887, he was made assistant librarian and teacher of telegraphy at the College, which position he resigned in January, 1889 , to enlist in Company "A," 4th Infantry. He was appointed Corporal, April, 1889; promoted Sergeant, December, 1889, and promoted to Quartermaster Sergeant 4th Infantry, December 10, 1890. From December, 1880. to December, 1890 , he was Sergeant Major, Fort Spokane, Washington. Sergeant Harbord won medals on the Department of the Columbia and Division of the Pacific rifle tenms of 1890; and February, 1891, was recommended by his Colonel for promotion to a Lieutenantcy. He passed a successful preliminary examination for the same at Vancouver Barracks, Washington, in April, 1891, and at this writing is Candidate Quartermaster Sergeant 4th Infantry, at Fort Sherman, Idaho.

Schurler C. HaRner, '90, was born in Steuben county, Indiana, in 1868. Since graduating he has taught in the public schools near his home at Leonardville, Kansas.

John K. Harrison, now a railway fostal clerk on the Missouri Pacific Railroad, was born at Kansas City, Kansas, in 1867. After graduating, in 
'88, he taught school for a term, and then accepted his present position. His address is Salina, Kansas.

JoHn S. HAzEN, '89, was born at Sabetha, Kansas, in 1862. After receiving the degree of B. Sc. he entered the U.S. Signal Service, in which occupation he is at present engaged at $\mathrm{Ft}$. Apache, Arizona.

John M. HiginbothaM, of the class of '86, was born at Manhattan, Kansas, in 186\%. Since graduating he has attended the Kansas State University and St. Mary's College in the pursuit of law studies, and is at present em ployed as cashier and head book-keeper with the S. F. Stokes Manufacturing Co., at 293 Wabash Are., Chicago, Ill.

Grorge E. HoPPer, who graduated from this College in '85, first brightened the home of his parents, who then lived on a dairy farm in Seneca, N. Y., on the 16th of November, 1861. Four years of his early life were spent among the Pennsylvania oil wells, his parents then emigrating with the "Greeley Colony" to Greeley, Colo., where they remained during one summer. They then moved to Freemont, Neb., and thence to Osborne county, Kansas, in 1870. Mr. Hopper was married June 4, 1882, to Miss Margery McElroy. Since graduating, his life has been somewhat varied. For three years he was foreman of the horticultural department of this College, after which his true American desire to manage something led him to become a contractor and builder, until 1888, since which time he has been city engineer and superintendent of water works at Manhattan, Kansas.

Maria C. Hopper Getty, was born in New York in 1865. She graduated in '86, and soon after was joined in marriage to Mr. Getty, since when she has been a housekeeper, her present address being Greenleaf, Kansas.

Florence F. Hough, '85, was born in lowa October 23, 1861. She is at present at her home in Melrose, Iowa.

Hontense L. Houston, '83, was born in Kansas in 1861. She is now engaged in teaching music at Concordia, Kansas.

Luella M. Hous'ron, ' 71 , is engaged in business as milliner and dressmaker at Concordia, Kansas.

Uluysses G. Houston, '81, was born 1860. Since graduating, he has been located in Manhattan, as an inventor. Two or three years ago he made an extended trip abroad, being baptized in the Jordan by Rev. T. DeWitt Talmage.

Walter C. Howard, clergyman in the Methodist Episcopal church at Winnebago, Ill., was born in Boston, Mass., May 16, 1852. He received his degree of B. Sc. in 1877, and in 1886 gruduated from the Garrett Biblical Institute at Evanston, I1l. On the first of May, 1878, he was joined in marriage to Miss Cassie J. Moore.

Fred. O. Hoyt, '77, was born in 1855 . He died in 1884 . 
Emma Hoyт Turner, '80, was born in Kansas in 1862. She is now a housewife, residing in St. Paul, Minn.

Louis E. Humphrey, '77, was born in New York in 1851. After graduation he was married to Miss Carrie Jackman, and is at preaent engaged in the drug business at Chapman, Kansas.

Frank A. Hutro was born in Indiana in 1860. He graduated in '85, and after teaching for a few years, began studying law at Topeka, Kansas. $\mathrm{He}$ is now a practicing lawyer of Stillwater, Oklahoma. He married Miss Lydia Arnold in 1888.

J. W. IJAms, '90, was born in Kansas in 1867. His address is Ozawkie, Jefferson county, Kansas.

Fletchen M. Jeffery was born in California in 1861. He graduated with the class of '81, and was for a time practicing law at Wetmore, Kansas, later at Escondido, Cal., and is now at Jewell City, Kansas.

Willaam J. JefFery was born in California in 1854. Since his graduation, with the class of ' 81 , he has been a minister of the gospel.

Humphrey W. Jones, '88, began his existence in Lehigh county, Pa., November 12, 1854. After graduating from this College he graduated from the State Normal school, and is now employed as principal of the Americus, Kansas, schools. On September 4, 1890, he was married to Miss Ida B. Laurey, of Lyons, Kansas.

Edwin H. Kern was born in Pennsylvania, May 30, 1859. He received his degree with the class of '84, and on March $: 7,1887$, was joined in marriage with Miss M. E. Wilson, of Mankato, Kansas. He is at present a civil engineer, architect and horticulturist at Mankato, Kansas.

Clara M. Keyes was born at Wabaunsee, Kansas, in 1868. Since graduating, in 1887, she has been teaching music in California.

Aldert B. Kimball, '89, was born at Manhattan, March 16, 1871. Since graduation he has been teaching school near Manhattan, Kansas, and is now taking a post-graduate course at this College.

Bentha S. Kimball, at present a post-graduate student in entomology and horticulture at the K.S. A. C., completed the college course in June, 1890. A term as teacher in a country school has occupied her attention during the past winter. She was born at Manhattan in 1872.

Carrie M. Kimball, '76, was born June 9, 1856, at Goffstown, New Hampshire. After graduation she was an art student in Los Angeles, California. She has been employed as a teacher and dressmaker, and is at present art instructor at Garden Grove, California.

Fred. G. Kimbald, '87, was born at Manhattan, Kansas, August 31, 1868. Since graduation he has been engaged in teaching and surveying, and is now farming at Garden Grove, Cal. 
Sam Kimble, A. B., was born at Sarahsville, Noble county, Ohio, June 19,1854 , and came to Kansas with his parents, in April, 1860, and lived on a farm five miles west of the present college up to the time of his gradua. tion at the Agricultural College under President Denison, in March, 1873; engaged in the survey of the Manhattan \& Northwestern Railway during the first year after his graduation; taught school on the Wild Cat during the following winter, and then engaged in the study of law the following summer, under Hon. R. B. Spilman, and while studying law taught the intermediate department of the Manhattan schools for seven months. $\mathrm{He}$ was admitted to the bar under Judge J. H. Austin. in Riley county, in March, 1875, and has been engaged in the practice of law at Manhattan ever since. Has served three terms as city attorney for Manhattan, and at the November election, 1890 , was elected on the Democratic ticket by a majority vote of 485 , as county attorney of Riley county. He was married January 1,1877 , to Anna C. Clark, who died in 1878 . In 1880 , he was married to Cora L. Ulrich, and now has three sons. His main contribution to the literature of the College was in the nature of an address entitled "Extremes," delivered in 1886, before the Webster Society, of which he was a charter nember. He now devotes his whole attention to law, in which profession he has an extensive and lucrative practice.

William KNABB, a native of Brown county, Kansas, was born June 4, 1867. Since graduating, in 1889 , he has been keeping books in a bank at Hiawatha, Kansas.

Warren Knaus was born near Portland, Indiana, in 1858. After graduating, in 1882, he took a post-graduate course, receiving the degree of M.Sc. He has since been a student and teacher, and is now editor and publisher of the McPherson Demoerat, at McPherson, Kansas. February 5, 1891, he was married to Jennie E. Coburn, of Salina.

H. Eusebia KNIPE was born on the 23d day of March, 1871, at Manhattan, where she still resides. She graduated with the class of ' 90 , and is at present taking a post-graduate course at this College.

Emma Krostman Huse, '80, was born in the blue grass State in 1860. She has been a teacher, but in 1887 was married to A. F. Huse, and is now a housewife in Arkansas City, Kansas.

Jas. F. LaTourette, "7\%, was born in New York in 1856. He is at present engaged in stock raising at Wagon Mound, N. M.

Darwin S. LEaCH, of the class of '81, was born in Wisconsin, 1865. He is now superintendent of the city schools at Georgetown, New Mexico.

Marion F, Leasure, "77, is a native of Ohio, and was born in 1853 After graduating, he chose as his profession, law, which is his present occupation. His office is at La Cygne, Kansas. 
MaRY C. LEE, '89, was born where she now resides, on College Hill, Riley county, Kansas, September 20, 1870. Since leaving college she has taught two terms of school, and is now at home:

AlLen Lewis, '85, was born in Ohio in 1862. He is now a civil engineer in Topeka, Kansas.

Marion M. LEwis was born in Indiana in 1861. After graduating with the class of '84, he attended a theological institute in Chicago, and is now engaged in the Baptist ministry at Superior City, Nebraska.

Nathan E. LEWIs, of the class of '88, was born in the state of Ohio January 6, 1867. Since graduation he has attended the Michigan University, and is now working as a mechanical draughtsman in the Vilis tool works, of Hamilton, Ohio.

William J. Lightroo'r, '81, began lis life at Malta, Morgan county, Ohio, March 8, 1867. After graduating, he spent one year at the K.S. U., and entered the government service as civil engineer, in which occupation he is still engaged at Jewell City, Kansas. His marriage certificate with Grace R. Strong, of Manhattan, Kansas, dates June 5, 1888.

E. ADA Litrue began the cycle of her life in 1867, at Manhattan, Kunsas. Graduating from the K. S. A.C. in '86, she took a course in music at the American Conservatory of Music in Chicago, Illinois. Since receiving the degree of B. Sc., she has taught in the Manhattan city schools, and was for a time a teacher of music at Marysville, Kansas. In the fall of 1890 , she became an assistant in the sewing and music departments at the Kansas State Agricultural College.

Nellie P. Litrue was born at Manhattan, Kansas, 1868. Taking advantage of a college at home, she completed the course in 1890 , and at once obtained a position as one of the teachers in the city schools of Manhattan, Kansas.

R. E. Lofrnck has been a shoemaker, gold miner, stock raiser, clerk and merchant since his graduation in 1875 . At present he is a jeweler and dealer in stationery in Manhattan. He was born in New York City in 1853. He has been twice married, his first wife being Miss Maggie I. Wilcox, and his last Miss Ella C. Sewell.

JACOB Lund was born in Denmark, 1857. After graduating with the class of ' 83 , he took a post-graduate course, receiving the Master degree. He served as foreman of the blacksmith shop at this institution till 1886, when he went to Las Vegas, New Mexico, where he is employed as engineer in the Hot Springs Hotel.

Mattie E. Mails Coons was born at Manhattan, Kansas, December 13, 1863. She graduated with the class of ' 82 , and in 1886 was joined in marriage with Mr. J. L. Coons, and since has been keeping house at Manhattun, Kansas. 
Abbie L. Marlate was born at Manhattan, Kansas, March 7, 1869. After graduating, in '88, she was employed as assistant in the sewing department in this College till the fall of 1890 , when she received the appointment of Professor of Household Economy, Hygiene, and Superintendent of Sewing in the Utah Agricultural College at Logan, Utah.

Charles L. Marlatt was born at Atchison, Kansas, September 26, 1863. After graduating, in 1884, he took a post-graduate course, receiving the Master's degree in 1887, and has been a student in the Columbia College at Washington, D.C. He served for two years as Assistant Entomologist and Horticulturist at this institution. In 1888 he received an appointment as assistant in the Department of Agriculture at Washington, D. C.

Frederick A. Mardatt, the present efficient assistant in entomology at the Kansas Experiment Station, was born on the present College grounds, in July, 1867. Graduating with the class of ' 87 , he has since continued special work in entomology. His connection with the Experiment Station dates from the summer of 1889 .

Ellsworth T. Martin is a Hoosier of 1865. After receiving his degree, in '90, he became a solicitor for the Gaskell Literary Club, and is now interested in a silver mine in Georgetown, Colo.

Dalinda Mason Cotey was born at East Greensboro, Vermont, on November 18, 1858. Early in her life her parents removed to Kansas, and soon afterward she entered the K. S. A. C., graduating with the class of '81. After graduating, she was, for some time, a teacher in the public school, and later took post-graduate studies at her alma mater. In the summer of 1887 she was offered the position of professor of domestic economy in the Dakota Agricultural College, situated at Brookings, S. D., at a salary of $\$ 900$ per year. She entered upon the duties of her department the following fall, having charge of both the cooking and sewing classes, and gave such lectures as usually accompany such a course; also had charge of the young women's coöperative boarding club. She continued the work in this line until the spring of 1890 , when, upon ber request, her resignation was accepted, as her duties took her too much from her own home. On November 28,1888 , she married Chas. J. Cotey, secretary of the South Dakota Agricultural College, who died June 4, 1890. Since the death of her husband Mrs. Cotey has made her home with her brother, S. C. Mason, at Manhattan, Kansas.

S. C. Mason was born in Vermont in 1857 , removed to Wisconsin with his parents in 1865, and thence to Kansas in 1871, locating on a homestead near Delphos, in Ottawa county. After securing what education was afforded by the district schools he began teaching, and so earned the means with which to attend the agricultural college, entering in the winter term of 1878 . Failing health compelled him to drop his studies before completing the course. He was married, in 1884, to Miss May V. Quinby, a former classmate, and engaged in farming in Clay county till the spring of 1888 , when the experi- 
ment station being organized, he was offered the position of assistant in horticulture, which he has since held. The necessary studies for completing the course being passed by examinations, he received the degree of Bachelor of Science with the class of 1890 .

Charles S. McConnelu, '78, a native of Iowa, was born in 1858. Since graduating he has been engaged as a printer, but is now in the employ of the State at Lansing, Kansas.

William J. McLaughlin received his degree of B. Sc., from the K. S. A. C. in 1887. He was born in 1863 , being a native of Kansas. Since graduating, his attention has been divided between his favorite occupations of farming and civil engineering. Communications will reach him at Centralia, Kansas.

Kate I. MEguire Sheldon, a native of the "Lone Star State," was born in 1858. She entered the K. S. A. C. in 1878, and graduated in 1883. After graduating she beld a position as teacher in a mission school. Later she went to California and there taught in a private school, and in 1887 she was married to M. M. Sheldon, and now resides at Riverside, Cal.

Alonzo A. Milus, assistant director at the Utah Agricultural College of Logan, Utah, was born at Keysville, Utah Territory, August 31, 1863. $\mathrm{He}$ graduated from this College in 1889.

William C. Moore, of Junction City, Kansas, editor and part owner of the Union, the third oldest paper in the State, was born at Harden, Clayton county, Iowa, August 26, 1864 . After graduating, in 1888, he became connected with a newspaper office, first as composer and later as an editor.

Wilton L. Morse, a native of Kansas, was born in 1867 , and graduated in 1890. Since becoming a B. Sc. he has been farming and teaching. He is at present located at Mancos, Colo.

Mary E. Moses, of the class of '87, was born at Unionville, Connecticut, January 1, 1866. She is at present, and has been since graduating, a student of the languages at Manhattan, Kansas.

Charles A. Murpur was born in Ohio in 1859. After receiving his degree from this institution in 1887 , he attended the State Normal and is at present a teacher in Argentine, Kansas.

Neluie J. Murphy, '85, was born in Ohio in 1863 . She has been employed as a teacher at Charity, Kansas, and is now a student of medicine in Taber, Kansas.

WIRT S. MyEns, of the class of '81, was born in lowa in 1859. He taught school for one year, after which he went into business as a woodworker in Tampa, Florida, where he now is. In 1881 he was married to Miss Viola I. Bacheller.

J. Dana N wedham, '83, was born in Kansas in 1862. He is now engaged in the mercantile business at Lane, Kansas. 
Lincoly H. NeIswender was born at Gahanna, Franklin county, Ohio, February 11. 1862. Since graduation, in 1884 , he has been a farmer and civil engineer, and is at present a farmer and stock raiser near Silver Lake, Kansas.

Albert E. Newman first saw light in the mountainous country of West Virginia, October 11, 1863. Since graduating with the class of '90, he has been a teacher, and is now conducting a stock farm near Lashmet, Kansas.

Ernest F. Nichols was born at Leavenworth, Kansas, June 1, 1869. After receiving his Bachelor's degree, in '88, he took special studies at this College, and in 1889 he became a student at Cornell University, where he now is. His address is 110 East State street, Ithaca, N. Y.

Susan W. Nichols, '89, was born in Brooklyn, N. Y., in 1868. She was employed at the College as assistant for some time, but is at present a music teacher, located at 1112 Corby street, St. Joseph, Mo.

ArThur L. Notes, '85, was born at Mendon, Illinois. Since his graduation he has been engaged in farming, and is now taking a course in electrical engineering at the State University, at Lawrence.

Walter H. Olin, '89, was born in California in 1862 . He has been a teacher and farmer, and is at present principal of the Waverly schools, at Waverly, Kansas. On November 26, 1890, he was married to Miss Winifred Cotton, a former student at this College.

Eli M. PADdLefond, a farmer, of Stockdale, Kansas, was born in Broome county, N ew York, in 1867. His B. Sc. certificate bears the date of 1889 . Since graduating he has had experience as a teacher in the public schools of his county, and also as warden in the Topeka Insane Asylum.

OrLando G. Palmer, '87, has been employed as a teacher since graduation, and is now employed in' the pension bureau at Washington, D. C.

Frank L. Parker, '86, was born in Iowa in 1862. Since graduating, he has been a merchant in Surprise, Kansas; address Tildon, Kansas.

Grace Parker Perry, '80, was born in 1863, and is a native of Kansas. After receiving her diploma at the K. S. A. C., she went to Washburn and completed the course at that institution in 1884 . On July 22,1886 , she was married to George Hazard Perry, a minister of the gospel. She now resides at Kiowa, Kansas.

Lours B. Parken, '87, was born at Kansas City, Kansas, in 1867. After graduation he followed the newspaper business. On June 24,1889 , he died at Manhattan, Kansas.

JAMEs E. PAyNE, '87, was born in Kansas in 1863. He has employed his time since the spring of 1887 as a teacher and farmer. He is at present farming near Edgerton, Kansas. 
Julta R. Pearce was born August 22, 1863, at Flint, Michigan. Since receiving her degree in ' 90 she has been employed as stenographer and clerk in the president's office at this College.

Geo. C. Pecr, a printer, of Junction City, Kansas, was born in New York in 1861. He graduated from this College in '84, and since then has been employed in the printing trade.

Hattie L. Peck Berry, '84, was born in New York, 1864. Soon after graduation she was joined in marriage with James $W$. Berry, and since then has been keeping house in Jewell City, Kansas.

Seward N. Peor was born in Saratoga county, N. Y., August $18,1859$. He graduated with the class of ' 87 , and has been since employed as draughtsman and cabinet maker in the mechanical department of Santa Fe R. R. shops at Topeka, Kansas. He lives at $\mathbf{4 1 0}$ Monroe street, Topeka.

Allie S. Peckeam Cordry was born in the State of Illinois, 1863. She graduated with the class of ' $\forall 2$, and soon after she was joined in marriage with Mr. Cordry. She is at present keeping house in Belleville, Kansas.

Edward H. Perry, '86, was born at Wrentham, Mass., in 1865. He was for a time editor of the Eskridge Star, and is now general salesman for the Bartholomew and Company's Real Estate and Loan business, at 609 Kansas avenue, Topeka, Kansas.

Emil C. Preutze, the youngest member of the class of '90, was born September 18, 1872, at Manhattan, Kansas. He has been connected with the Manhattan waterworks, in the capacity of engineer, since graduation.

H. Augustos Platt, '86, is a native of Kansas, and was born in 1862. He has been a farmer, and is now county clerk of Wichita county, Kansas; address, Coronado, Kansas.

George L. Platt was born in Illinois in 1861 . He moved to Kansas and took up studies in the Agricultural College, graduating with the class of '78. He died the same year.

John J. Points, '67, was married to Alice E. Stewart, '75, and is now practicing law at Omaha, Nebraska.

Clarence D. Pratt, '85, was born in the Hoosier State in 1865 . He has been a cattle raiser near Syracuse, Kansas, but is now a civil engineer in Salt Lake City, Utah.

Ada H. Quinbx Perry, was born at Wakefield, Kansas, April 10, 1864. She graduated in June of ' 86 , and the following October, was married to Edward H. Perry. Since then she has been keeping house in Topeka, Kan.

IDA H. Quinby Gardiner, '86, was born at Wakefield, Kansas, April 10, 1864. She was joined in marriage with I. D. Gardiner. October 7, 1886, and is at present associate editor of the Alma Neros, at Alma, Kansas. 
Corvin J. Reed, 79, was born at Chillicothe, Ohio, in 1861. For some time after graduation, he was a surveyor along the Pacific coast, and is now a farmer at St. Clere, Kansas. In 1882, he married Miss Flora Donaldson.

Minnie ReED, teacher of the city schools at Argentine, Kansas, is a native of the Buckeye State, having been born at Circleville, Ohio, in 1867. She became a member of the Alumni of this College in ' 86 , and since then has been employed as a teacher.

RoLLIN R. REEs, a graduate of '85, was born in Ohio, January 10, 1865. Choosing law as his profession, he is at present one of the leading lawyers of Minneapolis, Kansas.

Noble A. Richardson was born in Canada in 1858 . He received his degree with the class of ' 80 , and since then, has been superintendent of the public schools in San Bernardino, Cal.

Harry E. RobB, '88, was born at Deerfield, Iowa, on New Year's day, 186\%. He has been engaged in carpentry and bridge building, and is now farming near Neal, Kansas.

Dayid G. Robertson was born at Dixon, Ohio, in March, 1864. His Agricultural College education was completed in 1886. The principalship of the Downs, Kansas, schools in 1887; the study of law at Osborne, Kansas; a term, $1889 \cdot 90$, as clerk of the district court of Osborne county, has served to occupy the larger part of his time since graduation. In February, 1891, he was admitted to the bar, and is at present the junior member of the enterprising law firm of Mitchell \& Robertson, at Osborne, Kansas. His matrimonial engagement with Miss Hannah E. Coates, was consummated on Christmas day, 1888.

Frederick J. Rogers, '85, was born in Illinois, in 1863. He took a postgraduate course in 1886-7, receiving the Master's degree in June of ' 87. From 1887 to 1889 he was instructor in Physics at this College, but resigned his position to become a student in the Cornell University at Ithaca, N.Y., where he is at present.

H. C. Rushmont, "79, is now a prominent hardware dealer at Fort Payne, Alabama.

Lewis A. SAlter was born in Michigan in 1858 . When 21 years of age he graduated from the Kansas Agricultural College, and is now a merchant at Argonia, Kansas.

Wrlliam H. SaNders, '90, was born in Kansas in 1868. He has been employed as a telegraph operator a part of the time since graduation, but is now teaching at Lake Worth, Florida. In the fall of 1890 he was married to Hattie L. Gale, '89.

Nelitm SAwYer Kedzie, M. Sc., Manhattan, Kansas, professor of household economy and hygiene in Kansas State Agricultural College. (See Faculty.) 
Madde F. SaYkes, a Jayhawker, of the year of 1869, graduated with the class of '89, and since then has been keeping house for her parents at Ottawa, Kansas.

Dorothy E. C. Secrest Hungerford, of the class of '85, was born at Randolph, Kansas, in 1862. Un October 24, 1885, she was married to George H. Hungerford, and since then has been keeping house at Manhattan, Kansas.

MARIA E. SICkels Davis, '80, was born in Indiana in 1862. She is now a housewife, residing in Chicago, Ill.

Emma Secrest, '90, was born in Kansas in 1868. She has been employed this winter as a teacher near Randolph, Kansas.

Florine Secrest, '89, was born in 1867, at Randolph, Kansas, near which place she has been teaching since graduation.

Belle Selby, '82, was born in Ohio in 1860 . Since graduation she has attended the Cooper Art Institute in New York City, New York. She served for a time as Professor of Music at Lane University, Lecompton, Kansas. She is now teacher of art, drawing and music at 302-304, New York City, New York.

Marie B. Senn, was born at Enterprise, Kansas, in 1870. She received her degree with the class of ' 90 , and since then has been employed as teacher in her native county. Her present address is Enterprise, Kansas.

John W. Shartel, '84, was born in 1861, in Pennsylvania. A short time after graduating, he married Miss Effie E. Woods. He has served as county attorney of Chautauqua county, and is now a lawyer at Winfield, Kansas.

Burton L. Short, '82, was born in Illinois in 1856. He is now in the register of deeds' office, Kansas City, Kan.

William H. Sikes, "79, was born in Illinois in 1858 . Subsequently he moved to Kansas, and in 1875 entered the K. S. A. C. Since graduating, his attention has been given to the mercantile profession. On December 25, 1884, he was married to Mrs. Hilma Halstead. His address is Leonardville, Kansas.

EDWARD O. Sisson, the youngest member of the class of ' 86 , is a native of England, having been born at Gate's-Head-on-Tyne in May, 1869. Since completing the course, he has been engaged in teaching, and is now the principal of the Mound City, Kansas, schools.

JoHN A. SloAN was born in the Empire State, in 1858. Since graduating in '82, he has been married to Miss Ida Cranford, and is now a farmer and nurseryman in California.

ANNa SNyder began her life at Oskaloosa, Kansas, in 1868. Twenty years later she became a bachelor of science, and returning to her native town, she has since made that her home. 
Edwin H. SNyDER, '88, was born at Albany, Illinois, August 17, 1864. Since graduating he has spent most of his time as a printer, which trade lie learned at College. He has been foreman for the Riley \& Wake Printing Co., of Topeka, Kansas, and for the Stidger-Stern Printing Co., of Denver, Colo. He is at present editor and proprietor of the Highland Chief, it Highland, Colorado. On December 12, 1888, he was joined in marriage to Miss Dora Van Zile.

RALPF SNyder was the last of the list of Snyder graduates to complete the college course, his diploma being soarcely a year old. His earthly trials began in 1871. His occupations have always been of a strictly pastoral character, and he is a firm believer in the principles of the Farmers' Alliance, but lacks the political aspirations that characterize so many members of that movement. His home is at Oskaloosa, Kansas.

S'TANLeY Snyder was born at Oskaloosa, Kansas, December 21, 1866. With the exception of the time spent at college he has always resided in his native county. He is one of the few graduates that put into practice the knowledge of agriculture guined at the K. S. A. C. He received his degree in June, 1889.

Alice E. Stewart Points, '75, was born in 1854 . She is married to John J. Points, '67, and resides at Omaha, Neb.

Grorge E. Stoker, '90, resides at 917 Quincy street, North Topeka, Kansas, and does clerical work for the Santa Fe R. R. Co., at their office in Topeka. He was born at Topeka in 1871.

Walter T. Swingle, '90, was born in Kansas in 1871. He.prolonged his course in College for the purpose of doing special work in botany under Prof. Kellerman. After graduation, he was made assistant botanist to the Experiment Station, which position he resigned in 1891 to accept a $\$ 1,400$ place in the botanical division of the U. S. Department of Agriculture at Washington, D. C. He entered upon his duties the latter part of April.

Charles W. Thompson, the largest man in the class of '89, was born at Leavenworth, Kansas, in 1865. He has attended the Kansas City Dental College, and is now studying dentistry at Edwardsville, Kansas.

George N. Thompson, '87, was born at Belmond, Iowa, in 1863. The year following his graduation, he was foreman of the carpenter shop at the K. S. A. C., and is now a carpenter at Belmond, Iowa.

Albert Todo was born in the State of Rhode Island, in 1854. He lived in Kansas from 1856 to 1873 ; was graduated from this College in "72. In 1873, he was appointed a cadet at the U. S. Military Academy, and was graduated therefrom in 1877. He was then appointed a lieutenant in the artillery branch of the U.S. Army, which position he now holds. His army service has been at Fort Adams, R. I.; Fort Monroe, Va.; Vancouver Barracks, Wash.; Presidio of San Francisco, Cal.; Fort Hamilton, New York 
harbor; Pine Ridge Agency, S. D., (Sioux campaign, 1890-1,) and at Fort Riley, Kansas, where he is now located. From 1881 to 1884 , he was on duty as military instructor at this College. He received the degree of A. M. from the K. S. A. C. in 1887. In 1889, he was married to Miss Helen G. Pettes.

Jane Chapin Tunnelu is one of the College graduates that can claim Jayhawker nativity, having first looked around on Kansas prairies in the summer of 1871. She completed the college course before she had passed her eighteenth year, being the youngest of her class, and one of the youngest that ever joined the ranks of the alumni. Since her graduation she has been employed as assistant librarian at the K. S. A. C.

Ina M. Turner, '89, was born in Vermont in 1869. Since graduation she has been employed as printer at Topeka, Kansas.

WM. ULrich, M. Sc., of the class of '77, was born in Wellsburg, West Virginia, August 17, 1854. Since graduation he has been engaged as general contractor in Manhattan. In partnership with a brother, he has been extensively engaged in the cutting and shipping of limestone, quarried from the hills southwest of the city. He was married to Miriam Failyer sheffeld, June 7, 1888.

Oliver L. UTTER, a native of Crawfordville, Indiana, was born October 1, 1863. After graduating, in '88, from this College, he completed the English course at the State Normal school. Since graduating he has been principal of the Olsburg city schools, instructor in the U. S. Indian schools at Arkansas City, Kansas, and at present is a teacher in Emporia, Kansas.

John W. VAN Deventer, '86, is a native of Carrol county, Indiana, having been born at Delphi, June 25, 1858. He observed decoration day, 1889, by marrying Miss Alice P. Taylor. By profession he is a disciple of Horace Greeley, and is at present editor and publisher of a paper at Imperial, Nebraska.

Gilbert J. VAN ZiLe was born in the month of July, 1869. After receiving his diploma, in 1890, he employed his time as solicitor for the Gaskell Library Club, and is at present engaged in mining operations at Georgetown, Colo.

Elua Vincent MoCormick, '79, was born at Marshfield, Webster county, Mo., November 26, 1860. She was married to Geo. W. McCormick, September 30,1880 . Since her marriage she has been a book-keeper, in Clay Center, Kansas.

Romt. U. Waldraven was born in North Carolina in 1866. Since his graduation, in ' 89 , he has taught school for a time, and is now a farmer and stock raiser and Alliance organizer at Winkler's Mills, Kansas.

Aaron Walters, of the class of '88, was born in Bureau county, 1ll., September 16, 1864. For the past three years he has been engaged in teach- 
ing and the study of law, in Ottawa county, Kansas. Lately he has been admitted to the bar, and is now practicing his profession in Golden, Colo.

-MILAN T. WARD, '83, was born in Wisconsin in 1859: After graduation he studied medicine, and is now a practicing physician, at Orion, Ill.

George W. Waters, '86, was born in 1860, a native of West Virginia. For some time after graduating his time was occupied as a pedagogue. Later he received a position of mail route agent. His address is Riley, Kansas.

Lora L. Watkrs was born in West Virginia, Feb. 7, 1864. Since graduating, in '88, she has been teaching in Junction City, Kansas, where she now is.

William E. Whaley, of the class of '86, was born in the State of Missouri, 1861 . He has employed his time since 1886 as a teacher, and is now superintendent of the Manhattan schools.

Charles 0. Whedon, '71, is practicing law at Lincoln, Neb. Shortly after graduation he was married to Ella F. Denison, ' 71.

A. Judson WHite, of Atchison, Kansas, was born in Bourbon county, Kentucky, September 19, 1852. After graduating from this College, in 1874, he attended the Kentucky University, then entered the ministry, which profession he is still following. He was married to Miss Kate E. Graham, in 1883.

Kate E. White Turley, '71, is now a housewife, residing at Chicago, Ill.

Martha A. White Abbott, '67, is a housewife at Chicago, Ill.

HARRY N. WHITFORD, of the class of ' 90 , is a Jayhawker by birth, and a student by profession. He was born in 1872, at Manhattan. He taught school for a short time, and is at present clerking in a book store in his native town.

Mrnerva E. Whrtman Heiser, "76, is a native of Pennsylvania. She was born in 1853 . After graduating, she was married to A. B. Heiser, and now resides at Lyndon, Kansas.

F. Henrietta Willakd Calvin, '86, was born in Illinois, in 1865. Shortly after graduation, she was married to John H. Calvin, '84, and now resides at Topeka, Kansas.

Julius T. Willard was born in 1862 , near Wabaunsee, Kansas. He lived on a farm until early manhood, and in the fall of 1879 , entered this College with the class of ' 82 , but choosing chemistry as his vocation, he lengthened his course one year, in order to devote the afternoons and Saturdays of two years to the practice of quantitative analysis, graduating with the class of '83. During the last two years of his college course, he assisted in the instruction of laboratory classes in chemistry and mineralogy, and on graduating, was made assistant in chemistry, to work in that capacity onehalf the time. The other half was spent in post.graduate study of chemistry. He received the Master's degree in 1886. In 1884, he was made assistant on full time, and held the position until 1887 , when he resigned, to go to Johns 
Hopkins University, to further fit himself as a teacher of chemistry. There he had the great advantage of studying under the direction of Professors Remsen, Morse, and Renouf. Upon the organization of the Experiment Station at this College he was chosen assistant chemist of the Station, and began his duties July 1, 1888, which position he still occupies. He was married, in 1884, to Miss Lydia P. Gardiner, a student of the College.

HenRy S. Willard, '89, was born in Wabaunsee county, Kansas, in 1867. Since graduating, he has been a teacher in the public schools, and a student of medicine at Kansas City, Mo. At present he is pursuing his studies in the office of Dr. Robinson, at Manhattan.

S. Wendeli Williston was born at Boston, Mass., July 10, 1851 . He, with his parents, moved to Manhattan in 1857 , where he lived until graduating, in 1872, when he went to Yale College to act as assistant to Prof. Marsh, of the department of osteology, and later was made professor of anatomy of that institution. $\mathrm{He}$ is now professor of paleontology, and director of the University Geological Survey, at the K. S. U. at Lawrence, Kansas.

Amos E. Wilson was born in Ohio, March 2, 1860. His parents moved to Solomon City, Kansas, in the fall of 1872 , from which place he entered the K. S. A. C. in October of 1875 , graduating in 1878. He immediately entered into the banking business, which he has since followed, being at present cashier of the First National Bank of McPherson, Kansas. On March 21, 1883, he was married to Miss Kute G. Talpey, of Kansas City, Mo.

Thomas E. Wimer was born in Iowa in 1863 . He graduated in June of 1890 , but two weeks later died at the home of his parents, in Wayne, Kansas.

John L. Wise, '86, was born in Illinois, 1866. On New Year's day, 1888, he was joined in marriage with Miss Nannie Ridgeway. He is at present a merchant in Smithboro, Ill.

Grace Wonsetler, of '85, was born in Iowa, in 1865. She has been employed as a teacher, near Great Bend, Kansas, since receiving her Bachelor degree.

Clarence E. Wood, "79, was born in 1861, in the State of Vermont. Entering the K. S. A. C. in "75, he received his diploma in '79. Since graduating his time has chiefly been devoted to printing, that being his present occupation, in Denver, Colorado.

EFFIE E. WooDs Shartel, '85, was born in the State of Illinois, in 1864. She married John W. Shartel, of the class of '84, and is now keeping house at Winfield, Kansas.

Daniel W. Working, who graduated in '88, was born in Scott county, Minnesota, May 9, 1862. After graduation, he located in Denver, Colorado, where he was for a time editor of the Colorado Frarmer, and is now one of the editors of the Fancier and Farm Herald, published at Denver. . Aside from his editorial work, he has done much to advance the agricultural interests of his adopted State. In 1889 , and again in 1890 , he was appointed on a com- 
mittee to report on the work of the Colorado Experimental Station. At present he is lecturer of the Colorado State Grange.

Willis M. Wright, '87, was born in 1864, his native State being Ohio. After graduating, he removed from Manhattan to Lake Arthur, La., where he is now engaged in farming.

\section{William Aaron Anderson, Willium Sherman Arbuthnot, Herman Willard Avery, Judd Noble Bridgman, Robert James Brock, Francis Charles Burtis, Charles Albert Campbell, Spencer Norman Chaffee, Clay Ephram Coburn \\ CLASS OF' ' 91. \\ Leonardville, Riley. \\ Cuba, Republic. \\ Wakefield, Clay. \\ Atchison, Atchison. \\ Centralia, Nemaha. \\ Manhattan, Riley. \\ Manhattan, Riley. \\ Green, Clay.} Gertrude Coburn, Tina Louise Coburn, Rachel Callie Conwell, Christine Mossman Corlett, Mary Emmeline Cottrell, Phil Sheridan Creager, Kary Cadmus Davis, Thomas Clark Davis, Helen Pearl Dow, Anna Della Fairchild, Harry Beuson Gilstrap, Almon Arthur Gist, Amy Myrtle Harrington, Mayme Amelia Houghton, Delpha May Hoop, Willis Wesley Hutto, George Victor Johnson, Frank Mullett Linscott, Bessie Belle L ttle, Albert Edwin Martin,

Nellie Evangeline McDonald, David Collins McDowell, Alfred Midgley, Madeleine Wade Milner, Paul Chambers Milner, Harry Elbridge Moore, . John Otis Morse, Hattie May Noyes, Louise Reed,

Artemas Jackson Rudy, Henry Vernan Rudy, Lotta Jane Short Ben Skinner,

Carrie Scott Stingley, Lilian Alice St. John, Ellis Cheney Thayer, Sam L. Van Blarcom, Fanny Elizabeth Waugh, Frank Albert Waugh, Flora Emile Theresa Wiest, Bertha Winchip, Alired Orin Wright, Effie Jeanette Zimmerman,
Kansas City, Wyandotte.

Kansas City, Wyandotte.

Kansas City, Wyandotte.

Manhattun, Riley.

Guthrie, Oklahoma.

Wabaunsee, Wabaunsee.

Kuckley, Republic.

Junction City, Geary.

Benedict, Wilson.

Manhattan, Riley.

Manhattan, Riley.

Arkansas City, Cowley.

Manhattan, Kiley.

Junction City, Geary.

Manhattan, Riley.

Manhattan, Riley.

Manhattan, Riley.

Cedarvale, Cowley.

Holton, Jackson.

Manhattan, Riley.

Atchison, Atchison.

Manbattan, Riley.

Manhattan, Riley.

Minneapolis, Ottawa.

Manhattan, Riley.

Manhattan, Riley.

Topeka, Shawnee.

Mound City, Linn.

Wabaunsee, Wabaunsee.

St. Clere, Pottawatomie.

Manhattan, Riley.

Manhattan, Riley.

Blue Rapids, Marshall.

Fairview, Brown.

Manhattan, Riley.

Manhattan, Riley.

Maple Hill, Wabaunsee.

McPherson, McPherson.

McPherson, McPherson.

McPhersun, McPherson.

Manhattan, Riley.

Manliattan, Riley.

Manhattan, Riley.

Troy, Doniphan. 


\section{FOURTH-YEAR HISTORY.}

The class of ' 91 is the largest in the history of the institution, and it is interesting to note that the whole number graduated this year outnumbers the whole number graduated from this institution during the first seventeen years of its existence. A variety of circumstances has combined to produce this abnormal class. The first and foremost is, that many who entered with preceding classes, have been compelled, by financial circumstances over which they had no control, to forego the pleasure of being the happy recipient of a college diploma until the present year. Others have been compelled by the peculiar action of a college organization, known as the Faculty, to do likewise.

A small majority of the class matriculated according to the college catalogue in 1887; the Manhattan public schools furnishing a large number. With a single exception, all are residents of the "grasshopper" State, and all are typical Kansans,---reckless, goodlooking, wide-awake, energetic, egotistical, self-approbating, profdefying, and domineering. These attributes are characteristic of each and every member of the class; "Ergo, ex uno disce omnes."

As freshmen, these Jayhawker characteristics failed to crop out to any material extent, except the good looks, which were innate. As sophomores, their egotism began to develop; their patriotism displayed itself, not only in the large number of recruits which they furnished to the college battalion, but also in the formation of "Company Q;" while in the spring when P. M. was the order of the day, eight-cent pay-rolls brought to the surface their reckless and prof-defying spirit. Their experience as junior orators made their self-approbation plainly visible, probably far surpassing that of the original author; while their statesmanlike solution of the "race problem," their masterful compilations on the ever-green question of "labor and capital," with the dextrous manner in which they gleaned ideas on historical subjects from the Encyclopedia Brittanica has excited the admiration of many an enraptured audience. Their sleeplessness was manifested, both literally and figuratively, in the conception and execution of the highly commendable idea of celebrating their emancipation from the thralldom of farm and garden work through the medium of a grand jubilee ball, and in their subsequent ghost dances in the opera house. 
As seniors, their domineering proclivities were exemplified iu their selection of a class motto "We Want the Earth," and in their demands for a controlling voice in the general management of the institution.

Their energy found vent in their commercial transactions during the course in entomology; in the systematic manner in which they evolved fifty-two finished maps from a single delineation of some eight years standing; in the untiring efforts which they put forth to discover original ideas and illustrations for the benefit of the professor in fourth-year agriculture; and of late has been personified and concentrated in the seven members who constitute the Symposium Company, and who solicit subscriptions from daylight till dark, from Monday morning till Saturday night.

The morals of the class have ever been above reproach. They bave never taken part in any of the disreputable work for which some of the other classes have achieved so unenviable a reputation, and they have always endeavored, by their upright conduct and the conscientious discharge of their duties, to merit the approbation which has been so cheerfully accorded them. Nearly all have, at some time during their course, attended Sabbath school, have semioccasionally attended the weekly prayer meetings; some have learned to discourse at the Y. P. S. C. E., and all have, so far as their financial condition would allow, contributed to the support of home and foreign missions.

Taking it altogether, this class does not differ materially from the classes that have preceded it. They hunted botany specimens on the same hills; they passed in the same entomological collections that have done duty for the last fifteen years; they filled the same silos and curried the same bovines; they stole the same brand of cider from the same cellar; they told the same jokes, and have listened to the same stories in chapel; and when the glorious orb of day shall dispel the mists on the morning of June 11, they will go out into the same world to subsist upon the same charity that has furnished previous classes means of keeping body and soul intact.

\section{STATISTICAL.}

The class of '91 consists of fifty-two members - thirty gentlemen and twenty-two ladies. Their ages range from eighteen to 
twenty-seven and a half, the average age of the class being about twenty-one and a half years. Twenty-three of the class were born in Kansas; eight in Illinois; four in Iowa; three in Michigan; two each in New York, Indiana, Missouri and Wisconsin; and one each in Ohio, Massachusetts, New Jersey, Pennsylvania, West Virginia and Canada.

The parents of twenty are engaged in farming; of three in stock raising; of three in journalism; of two in the livery business; of two in the ministry; of two as vineyardists; and of one each in the following occupations: grain dealing, hotel keeping, as mayor, as congressman, coal dealing, as postmaster, as college president, as photographer, as banker, as physician, as superintendent of sewing. Parents of six have no occupation, while two of the class are orphans.

Only ten of the class were self supporting before entering college, while the others depended on their parents or guardians for their support, and had spent the most of their time in school.

For their future occupation, ten propose to engage in teaching; five in farming; four in housekeeping; four in journalism; three in printing; two in horticulture; two in music; and one each in the following: telegraphy, taxidermy, engineering and draughting, law, floriculture, railroading, electrical engineering, ministry, medicine, U. S. Army, and photography. Eleven are undecided as to how to best provide for their future welfare.

As to religion, eleven are Presbyterians, five are Congregationalists, three are Methodists, two are Episcopalians, two are Baptists, and one is a member of the Christian church. Twenty-eight have made no profession of religion.

As to politics, twenty-eight are Republicans, seven are members of the Peoples' party, five are Democrats, five are independent, two are Prohibitionists, one is a Prohibition-Democrat, and five are non-coinmittal.

During their college course, fifteen have been Websters, thirteen have been Hamiltons, twelve have been Ionians, eight have been Alpha Betas, and four have never united with any society.

The time spent in college by the members of the class varies from eight to sixteen terms. Twenty-eight took the allotted time of four years; one completed the course in eight terms; one in 
eight and a half; three in nine; two in ten; three in eleven; four in eleven and a half; two in thirteen; three in fourteen; three in fifteen, and one in sixteen terms; the average time spent by the members of the class being eleven and nine-tenths terms.

\section{THIRD-YEAR HISTORY.}

Glancing back over the experiences of past years, the reader can perhaps recall a day, of all others, the memory of which can never die - the day he entered college.

For weeks previously, he had tried to imagine what his new life would be like. His mind was filled with the buildings and scenes pictured in the catalogue, and with speculations as to the character, nativity and ability of his future classmates. The day at last arrives, and with a number of others who have been looking forward with the same fears and hopes, he finds himself in the school; be sees in reality the buildings, grounds and classmates which before he had only known in imagination. $\mathrm{He}$ is at last at the College, with all the trials and pleasures of his new life before him. The first of his trials is the entrance examination. His young, anticipative mind had, during the preceding days, greatly magnified the rigor of the test, and, timidly, feelingly, like a stranger in a foreign land, he enters upon the trial.

If the reader has known this experience, he can readily appreciate the situation of the two hundred and fifty girls and boys who first assembled at this College September 12, 1888.

Four years had they before them, years in which their greenness should give place to infinite wisdom. The process was to be long and painful, and ere its completion their ranks would be greatly thinned. But they are now in the last stage of the race; the two hundred and fifty has dwindled to fifty, and they are still marching on. Each term sees their number made smaller and their wisdom made greater.

It is the purpose of this article to briefly glance over their path, and see the steps by which this selection and perfection has been effected.

Throughout its course the class has been remarkable for the number of professors it has initiated, the number of botany specimens collected, the multitude of insects destroyed, and the great 
number, variety and originality of the theories advanced on all subjects during examinations.

It is hardly necessary to speak of the various ordeals of the first year of book-keeping, word analysis and botany. There were the usual number of excursions, and the beauty of the landscape was, doubtless, as effectually marred by the loss of flowers, as at any time before or since.

After a vacation of three months, one hundred and five of the first-years of 1888 -89 returned to continue their course, but no longer as freshmen. They had climbed one round of the ladder, and now felt able to master anything the second year could furnish. However, this feeling of satisfaction and power was soon changed to one of despondency, for the mathematical professor introduced them to the mysteries of quadratics and they soon saw the weakness of second-year intellect. The year rolled on and the spring term opened unusually pleasant for the class. Before two weeks had passed one could see bug nets in all directions, and it is possible that a few had bugs in them. During this term, according to tra. dition and custom, the boys received a course in farm and garden industrial, nicknamed $P$. M. This course was very thorough, but some of the boys were not, and as a result only received eight cents per hour, but this did nct hurt their consciences any, for they knew that it was according to precedent. Although "bug-hunting" and P. M. are not the hardest kinds of work, they were all glad when commencement came.

The fall term of their third year opened with about fifty present. Friendly greetings was the first order, and when they assembled in their class rooms a few well known faces were absent. During this term the class made its debut in public, and no one was at all surprised to hear some oratory come from their worthy members. P. M. was still a part of the programme, and when the class was emancipated they celebrated their liberty by a social, given in one of the town halls.

The winter term was a repetition of the same routine which had been gone over for years. The most pleasant event being the Mechanics' party, given the class by Professor and Mrs. Hood. Here all enjoyed themselves and went away feeling that there were some advantages in studying mechanics. A few more tales might 
be told of the present junior class, but these are the principal historical facts.

\section{SECOND-YEAR HISTORI.}

The class which entered College in the fall of 1889 , was the largest freshman class in the history of the institution. It numbered three hundred and seven students - one hundred and thirteen ladies, and one hundred and ninety-four gentlemen. Of this number, two hundred and eighty-nine were from the various counties of Kansas, while eighteen came from eight other States and Territories.

As might naturally be expected, there was much difference in the preparation these many students had received. Some were graduates of city high schools, some held teachers' certificates, some were former students of like educational institutions, but many came directly from the farm.

The ages of the students at entrance ranged from fourteen to twenty-five years, the average being about nineteen. The majority of the class came from well-to-do families, but a number of the gentlemen were entirely dependent upon their own exertions for support. The foolish pride often shown by students of other schools is an unknown quantity in this class, all recognizing the fact that following the plow is as honorable, if not as dignified, as wielding the sceptre. Some of the most popular members in the class are those who are working their own way.

The sophomores have an excellent record for scholarship, comparatively few failures having occurred; while in the various industrials, they have outstripped all of their predecessors. Among the ladies may be found good seamstresses, compositors and telegraph operators, while the delicious dinners and lunches prepared and served by their hands have won for them a reputation as model cooks. Each gentleman in the class has had at least one term's work in the carpenter shop. Some having pursued wood-working for five terms are very good carpenters. Others have taken different industrials, and have made good progress. As P. M.ists they have earned and received as hearty words of approval as ever cheered the gloomy pathway of previous pilgrims through the trying ordeal of "farm and garden work."

At play, as at work, the class is in dead earnest. Before the 
end of their freshman year, they had possession of the base ball championship, which they still hold against all opposing " nines." Although they have no football team of their own, they furnish some of the best players for the other teams.

Nearly all of the members of the class belong to some one of the college societies, and are among the hardest workers in each. Many of the society offices have been well and acceptably filled by second-years.

Although only half of the milestones of the course have been passed, or are in sight, there have been many incidents which will, in years to come, yield pleasant recollections. Among them we might mention the botanizing trips to File Creek, St. George, and Eureka Lake, whither we went in twos, in fours, and in whole 'bus loads, to fill our herbariums. How many of those flowers, tortured in presses till dry, then glued to paper and labeled carefully with the Latin, and better known Yankee names, will some time recall to mind the friends we rambled with, the cold dinners we ate, the long, happy days we spent in the woods, and the jolly rides home in the evening!

And can we, or will we ever forget our first "real own" class party, given to the Agriculture and Household Economy classes, by Prof. and Mrs. Georgeson, where, if the boys did outnumber the girls two to one, there were smiles and eatables enough to go around anyway? What visions of the supper, which made our ordinary boarding house fare sink into insignificance, will rise before our minds, when, with eyes grown dim, we try to read the familiar names written on our Japanese napkins by our classmates, on that memorable evening years before.

The "bugs" we collected on our trips to the Wild Cat, up the Blue, or to Fort Riley, will sometime be valued more highly for the associations they bring to mind, than for their rarity; and when that time comes, may we all have forgotten the long and tedious hours spent in learning their euphonic, but unpronounceable names.

A. D.

FIRST-YEAR HISTORY.

The class of ' 94 , having been a part of the K. S. A. C. for so short a time, has but little that may be said of it in a historical way It can be said of this class, however, as it can be said of every other 
CLASSES.

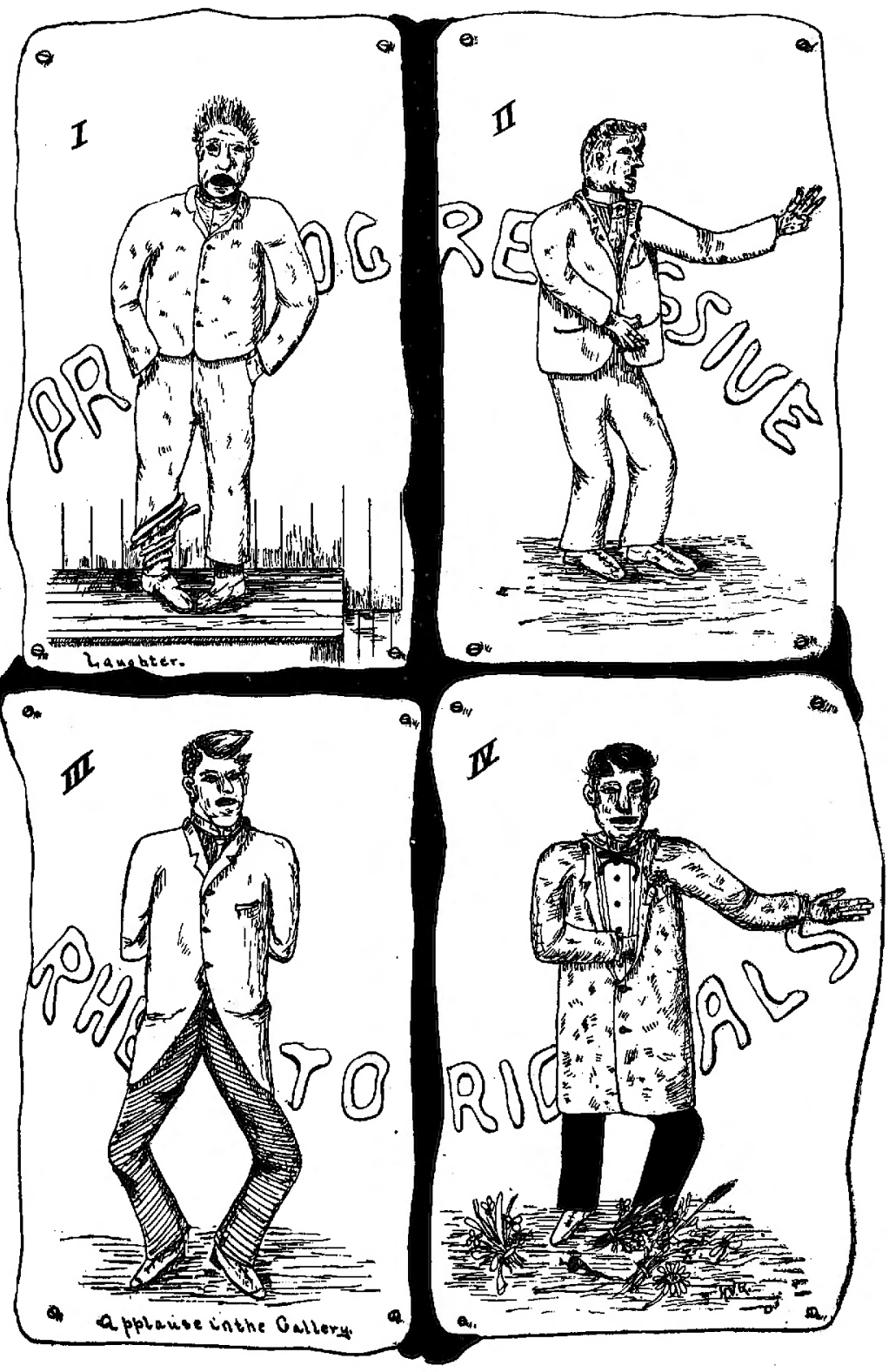


class, that it was the largest in the history of the institution. It numbers over 350 members, of whom about 140 are ladies, and 210 gentlemen. Their ages range from fourteen to twenty-eight years, and they came from every part of Kansas, only a few claiming residence outside of the State. They were altogether the best looking lot of young men and women ever seen together anywhere.

To be sure, some of them were not very well versed in society etiquette, but three weeks' association with the polished sophomores, accompanied by a careful, though necessarily distant, observation of the "tony" seniors, transformed the emerald prep. into the straightforward, mind-your-own-business first-year.

It cannot be said that anything of interest has befallen them as a class. The most of them have attended strictly to business; tho rest of them have left. They have all been to the Scientific Clul, once, to prayer meeting once, and some have attended the Y.M. C. A., P. M. meeting. They have learned to passively endure the Friday exencises, and have had duly impressed upon their plastic minds some slight appreciation of the distinction which calls their own efforts declamations, and those of the worthy juniors orations.

They have been to several of the college socials, and most of them have learned better than to go again. They helped pull the cannon to the top of Bluemont; they were present when the agricultural professor's horse had his tail cut pompadour; they opened the water-hydrants, and they locked the Hamiltons' door. They have seen everything worth seeing, heard everything worth hearing, and learned everything worth learning, and if it were not for violating a long established precedent, they would graduate this Commencement and go out in the world to sponge off their relatives, or get fat offices in other agricultural colleges along with the class of ' 91 . But, as it is, they will probably keep right on in the even tenor of their way for three more years, and when the proper time comes, the class of ' 94 will get their sheepskins according to the orthodox program and leave the College, which will be the better for their having been a part of it, and the professors, who will be happier for having known them. 


\section{YOUNG MEN'S CHRISTIAN ASSOCIATION.}

The Cullege Young Men's Christian Association was organized November 8, 1885. It had been previously announced that $\mathrm{Mr}$. C. K. Ober, secretary of the international committee of college assuciations, would address- the students on the history and work of college associations with a view to organization, and on that evening twenty-five young men met in the Congregational church to consider the matter. After listening to Mr. Ober's address and the reading of the constitution recommended by him, it was decided by a unanimous vote to organize an association at the College, adopting the constitution recommended. At the second meeting, held November 13, the organization was completed by the election of G. D. Robertson, '86, president, and C. A. Murphy, '87, secretary.

The regular services were gospel meetings held in the Horticultural Hall each Sunday afternoon. For the first year the average attendance was twenty-five. Two Bible classes were organized the following January, and the work in all lines was increased. The following year, C. A. Murphy, '87, was elected president, and L. B. Parker, ' 87 , secretary. One delegate was sent to the State convention at Ottawa. The work of this year showed an increased interest, the average attendance at the meetings being raised to thirty-two. D. G. Fairchild, '88, was chosen president for the following year, and W.H.Olin,'89, secretary. The next year, 1888-9, D. E. Bundy, '89, was president and W.H. Sanders, '90, secretary.

W. H. Sanders, '90, was president for 1889-90, and H. B. Gil. strap, '91, was secretary. The association this year, published a directory for new students, and organized a reception committee to meet them at the train. The association was represented at the Topeka convention by fifteen delegates.

At present H. B. Gilstrap, '91, is president, and B. H. Pugh, '92, is secretary. The reception work at trains was this year continued with considerable success. The meetings have been well attended, and with good results. At the present time the membership is larger than ever before. 


\section{YOUNG WOMEN'S CHRISTIAN ASSOCIATION.}

The Young Women's Christian Association of the Kansas Ag. ricultural College, was organized November 17, 1885, with Miss F. Henrietta Willard, president, and Miss Nellie Cottrell, secretary.

The meetings were held in class room I, at 4 o'clock, P. M., for some months, afterward being changed to the South Society room for the convenience of an organ. The time came when it seemed desirable to hold the meeting in connection with the students' prayer meeting, which then met regularly on Friday evenings, so the Y. W. C. A. became a "twilight meeting." This year, the young women have held their meetings every Friday evening, occasionally merging it into a joint meeting with the Y. M. C. A. To these joint meetings all students are cordially invited.

\section{COLLEGE BATTALION.}

Lieut. E. B. Bolton, 23d U. S. Infantry, commander.

Judd N. Bridgman, Adjutant.

George V. Johnson, Sergeant Major.

John W. Hartley, Color Sergeant.

Harry B. Gilstrap, Captain Co. "A."

Robert J. Brock, Captain Co. "F."

John O. Morse, Captain Co. "C."

David C. McDowell, Captain Co. "B."

George W. Wildin, Captain Co. "E."

Alfred Midgley, Captain Co. "D."

A. A. Gist, Captain of Battery. 


\section{COLLEGE CADET BAND.}

Prof. A. B. Brown, , . Director.
A. E. Campbell, Piccolo, . . Secretary.

F. A. Waugh, •. . . B flat Flute, . . President and Leader.

E. M. S. Curtis, . . B-flat Clarinet,

C. B. Selby, . . . . . Solo B-flat Cornet.

Chas. Lyman, . . . 1st B-flat Cornet.

S. R. Moore, . . . 2d B-flat Corn et.
A. A. Gist, Solo Alto.
F. F. Baxter,
1st Alto.
C. R. Hutchings,
1st Tenor.
E. L. Frowe,
2nd Tenor.
R. A. Clark,
C. A. Bailey,
Baritone,
W. E. Smith,
E-flat Tuta.
G. C. Gentes,
- Snare Drum.
F. J. Bartel,
Base Drum.

Slide Trombone.

Treasurer.

\section{INDUSTRIALIST.}

Edited by the students and faculty, and published weekly.

Student Editors: Tina L. Coburn, Geo. V. Johnson, and Ben Skinner. 


\section{SCIENTIFIC CLUB.}

The propriety of organizing a society for individual improvement in the natural and allied sciences, had been discussed and advocated by a portion of the faculty and a number of the advanced students, for nearly a year. In order to take some definite action upon the matter, the following named persons met in the Physical Laboratory, on Friday evening, January 30, 1880: Professors Failyer, Popenoe and Graham, and students D. S. Leach, A. Beacham and W. Knaus. It was unanimously agreed to organize a society for the purpose above named. After some discussion as to scope of the work to be undertaken by the society, the meeting adjourned to meet in one week, with the understanding that the professors present should bring the matter before the faculty, and request its consent to make the society a permanent organization. The next week, the same half dozen met, pursuant to adjournment, and, after some discussion, named the organization the "Scientific Club of the Agricultural College," and adopted a constitution. Professor G. H. Failyer was elected president, and a scheme for future work was laid out. For convenience of work, the club was divided into sections as follows: A, Biology; B, Botany; C, Cheniistry; D, Physies; E, Engineering; F, Zoölogy; G, Geology. To this list was added, in the fall of 1890 , an Electrical division. The club, although it has labored under many disadvantages, has carried on a vast amount of original research, and aided greatly in disseminating scientific knowledge.

The club meets the fourth Friday of each month, (providence permitting ) and is open to both ladies and gentlemen.

Professor I. D. Graham is now president, and Bertha Bacheller secretary. 


\section{IONIAN SOCIETY.}

\section{HISTORY.}

During the spring term and summer vacation of $188 \%$, the question of a young ladies' literary society was agitated to a considerable extent. The first day of the fall term of '87 found a group of girls engaged in discussing the advisability of making such a move. Finally, with the aid and approval of Mrs. Kedzie, the plan was tried. Committees were appointed to draw up a constitution and by-laws, under which officers were elected as follows:

Julia R. Pearce, President.

Dora Van Zile, Vice-President.

Nellie P. Little, Recording Secretary.

Carrie K. Hunter, Corresponding Secretary.

Tina Louise Coburn, Marshal.

Twenty-three organizing mernbers were enrolled. Their names are as follows:

Alice Abbott,

Allie Atwood, Gertie Coburn, Tina L. Coburu, Minnie Cowell, Eunice Donaldson, Anna Fairchild, Franc Green,

Carrie K. Hunter.
Doris Kinney,
Mary Lee,
Nellie Little,
Tulliola McCormick,
Susan Nichols,
Josie Pearce,
Julia Pearce,

Carrie K. Hunter.

Anna Snyder, Jane Tunnell, Alice Vail, Dora Van Zile, Fanny Waugh, Flora Wiest, Esther Zeitz.

The progress of this new society was watched with much interest by everyone, and the faculty thought there was no harm in trying the experiment.

Meetings were held in the north corridor until the fall of '88, when the southeast room in the third story was given to the Hamilton and the Ionian societies as their future meeting place. By them it was transformed from a bare, uninviting room to the cosy, well-furnished society room which it now is. The society has grown until now it is one of the strongest of the four literary organizations, and has a membership of over sixty. The large and constantly increasing membership will necessitate more spacious apartments in the near future. 
The object of the society is, as stated in the words of the preamble of the constitution, "For our mutual improvement and the cultivation of the forensic art, literature, and music." In the years the society has existed and flourished, it has more than accomplished the objects stated in the few words of the preamble. Parliamentary rulings in the society have never been extensively practiced, because the work of the society has ever been so harmonious that much knowledge of these rules has never been necessary.

The ladies who have presided over this society are in order as follows:

Julia R. Pearce, fall, '87. Anna Snyder, winter, ' 88 . Minnie Cowell, spring, '88. Jennie C. Tunnell, fall, '88. Susan W. Nichols, winter, ' 89. Gertie Coburn, spring, ' 89 .
Fanny E. Waugh, fall, '89. Julia R. Pearce, winter, '90. Mayme A. Houghton, spring, '90. Tina L. Coburn, fall, '90. Alice Vail, winter, '91. Maude E. Whitney, spring, '91.

In the spring term of ' 90 the society, as its first effort at public entertainment, ventured to give an exhibition. The effort was pronounced by all one of the very best entertainments of the kind ever given in the college chapel. The second annual exhibition, given April 24, 1891, was considered an improvement, if possible, on the one given April 25, 1890.

We can but hope that the society will exist in the years to come as a necessary part of the K. S. A. C., and that its work and influence will aid many Kansas girls to become good, true women.

\section{PRESENT ATTENDING MEMBERS.}

'91.

Gertie Coburn, Tina L. Coburn,

Effie Gilstrap, Susie Hall,

Inez Avery, Vildred Frost, Jessie Hunter, Maude Knickerbocker, Mary Lyman, Edith McDowell,
Mayme Houghton,

Lotta Short, 92. Alice Vail, Ora Wells, '93.

Eusebia Mudge, Lizzie Myers, Bessie Morrison, Clara Pender, lda Pape, Kate Pierce,
Carrie Stingley, Fanny Waugh.

Maude Whitney.
Mary Pierce, Ada Rice, Jennie Selby, Clara Short, Phœbe Turner, Dora Thompson, Jessie Whitford. 
94.

$\begin{array}{lll}\text { Emma Adams, } & \text { Harriet Dodson, } & \text { Ellen Nilson, } \\ \text { Carrie Bentty, } & \text { Josie Finley, } & \text { Martha Pape, } \\ \text { Florence Corbett, } & \text { Maria Hanlin, } & \text { Lottie Puckett, } \\ \text { Mabel Cornell, } & \text { Gertrude Iaulenbeck, } & \text { Mabel Selby, } \\ \text { Verta Cress, } & \text { Marie Haulenbeck, } & \text { Lillie Secrest, } \\ \text { Elsie Crump, } & \text { Blanche Hayes, } & \text { Ida Staver, } \\ \text { Daisy Day, } & \text { Rena Helder, } & \text { Emma Stump, } \\ \text { Flora Day, } & \text { Alice Horton, } & \text { Jessie Tinkham, } \\ \text { Lillian Davis, } & \text { Ivy Kellerman, } & \text { Hilda Walters, } \\ \text { Ione Dewey, } & \text { Minnie Moffett, } & \text { Myrtle Whaley, } \\ & & \text { Fannah Wetzig. }\end{array}$

THE OLD WORLD AND THE NEW.

by JULIA R. PEABoe.

[ $A \mathrm{n}$ address at the First Annual Exhibition of the Ionian Society, of the State Agricultural College.]

Europe is a continent of literature, America a continent of in. vention. These two, placed on opposite sides of the earth, with the rolling Atlantic between, are not more widely separated in their position than they are in their characteristics.

Europe, by her broken surface and irregular coast line, is divided into small nations, each living so distinct from the other that entirely different languages may sometimes be found on the opposite sides of a mountain. America, with her sweeping prairies and vast extent, is peopled with one nation, the American, as it were, with one purpose, one interest, from Cape Horn to Baffin's Bay. The Europeans, reared for ages in the narrow confines of small districts, hemmed in by mountains, have had to let their minds soar upward, the only outlet; so their productions have been idealistic, and on their roll of fame are names of great sculptors, poets, dramatists, artists, and singers. The myths and legends which are to be found among every petty tribe gave food for poetic fancy. The stability of their institutions gave but little chance for change and reformation. Each man lived the life laid down for him andi never felt the restless activity of the American, who knows that each man's fortune depends upon his own exertions. Here, the trials and privations of a pioneer's life left no room for dreaming. He must depend on labor and inventive genius to furnish him the 
tools which he could not afford to have sent from Europe. The intense activity of the American people is in direct contrast to the life of the plodding peasant. The rush of business and whirr of inachinery has taken the place of the speculation and theory of the European. Europe has a poet or a poet's memory in every glade. America has a whittling Yankee at every gate post.

And that Yankee! Compare him with the stolid, slow going, indifferent German, and you have the types of the New World and the Old. From the well fed Englishman, who spends three hours at his dinner, to Hans Schmidt, who sits smoking with his companions and drinking beer in the coffee house, on south to the indolent Spaniard and Italian, who spend their days lolling in the sun and their nights in amorously rattling the castanet or twanging their guitars, all Europe has been content to do as their fathers have done. The same old latch, the same old plow, the queer, uncomfortable furniture will do, as it has done for ages.

The Yankee, the inventive, the inquisitive, honest hearted Yankee is a product of America only. His native haunts were among the hills of New England; but he went west. His descendants scattered all over this glorious continent, and may now be found anywhere on the road from Terra del Fuego to Behring Straits, till all the Americas have been Yankeefied. What is the characteristic of the Yankee that distinguishes him from the European? Go into any New England home for your answer. He will hasten to show you his new lock, hinge, wrench, a gate that will open when the carriage approaches and close when it is passed, or a machine for baking buckwheat cakes, into which you put the batter and receive in three minutes a hot cake. All about his premises are multitudes of these little labor saving contrivances which he proudly shows to foreigners, and explains the details and how they all work; for everything works from the patented lemon squeezer to a steam engine or the Atlantic cable. Everything he knows he applies.

This application of scientific truth is characteristic of the American. He hasn't the turn for the careful investigation of the true scientist merely for the love of it. The European investigates; the American applies the principles. Nowhere in America do we find such universities as they have in Germany. They study science as a purely intellectual gymnastics, and the American, tak- 
ing their knowledge, applies it to the needs of mankind; makes it carry his burdens, light his houses and streets, print his books, or even talk for him, as the phonograph now does. The foundation of science lies in the fact "of the indestructibility of the two products of creation-matter and force, and the fruit of their union-energy." It has been the work of the American to apply this energy. The Frenchman Boursuel could discover the principles of transmitting sound to a distance; but it took Graham Bell to make the telephone. Jablakoff could introduce electric candles; but it took an American to produce the electric lighting system. A European could predict the steamboat and possibly tell you how it might be made; but it took a Yankee to make it and make it go. While the Old World swung the scythe, McCormick made his famous reaper. For ages sewing girls stitched patiently away until a Yankee comes forward with the sewing machine. We have no Darwin, no Pasteur; but we have Cyrus Field and we've an Edison.

A nation that contributes nothing to civilization and the progress of the human race has little right to its existence. What claim has the United States on the recognition of the world? Has she paid the debt of nation to nation? Let her records answer. No American need blush for his country's share in the production of the world's good, as he sends his messages across the continent or across the ocean on Yankee telegraph lines and Yankee ocean cables. The Arabian carried his civilization to the Atlantic Ocean and turned bark. The Yankee doesn't stop for any Atlantic Ocean, but sends his steamers over it, his cables under it, and his torpedoes through it.

Take from the world the work of Edison alone, and we would feel what America bas done for civilization. This man, with his ceaseless activity, his inventive genius, simple in his habits, frank and cordial in his manner, keen in observation, quick to see and apply whatever may be put to his use, independent, practical in all his work, he combines the qualities and attributes of a typical American.

The dream of Henry Clay was "a continent of closely allied Republics, settling all difficulties and differences in an occasional Congress on the Isthmus of Darien, wherein the honorable giant 
from Patagonia might join in harmonious debate with the honorable dwarf from Greenland." Whatever may be the future of our continent, the remotest parts united by the telegraph line, and one, two, three, four messages at the same time, and on the same wire, are flashed from ocean to ocean, from Arctic to Antarctic, when by means of the telephone and phonograph the pastor of Trinity Church preaches on Sunday morning to a congregation seated in their homes in Alaska, in California and in Chili, we will indeed be one people, and a man's neighbors will be the inhabitants of the American continent.

We will not shrink from the comparison of European Bard with American Inventor. As electricity sheds its beautiful light over American city and European city alike, sending its intense rays into the darkest alleys and byways, lighting the pathway of the traveler, or revealing the haunts of crime, so American science and Yankee ingenuity have sent their light to all the human race, enlightening with knowledge the darkest corners of the earth. And when, in the final marshalling of the nations, the benefactors of mankind shall be brought face to face, the Yankee will be given his reward, and Shakespeare will step across the ages to shake hands with our Edison.

YOUNG AMERICA.

[Oration delivered at the Ionian Annual, 1891, by Gertie Coburn.]

The modern girl, being an interesting creature, is much talked of, praised, blamed, loved and laughed at. Her brothers seem to be rather. neglected, but while they are less popular and lovable they are fully as interesting and important. In this fast age the young people are accused of much nonsense, giddiness and mischief, but our best friends believe that we have a good deal of seriousness and practical sense ready when occasion demands it. While others are talking about us we may well turn our attention for a few minutes to ourselves, and, recognizing the fact that we boys and girls of this generation are about taking our places as the men and women of America, look soberly behind, joyfully around, and hopefully before us.

To feel our insignificance and weakness and inability, we have only to face the fact that for the first quarter of the 20th century the security, prosperity and glory of our nation depends on young 
America personally. To realize our strength, and gain courage for the race before us, we need only to make a little inventory of our wealth, advantages, privileges and abilities, and remember from whom we inherit strength, perseverance and energy.

In general, we occupy a position unparalleled in the history of the nations. I know it is the tendency of history and biography, poetry and romance, to make us think our ancestors far above us in every way. If a little distance lends enchantment, much lends more, and the farther back we go the more glowing the colors become, until in the "remotest antiquity," in "the glory that was Greece and the grandeur that was Rome," are found subjects sufficiently indefinite and obscure to exhaust our vocabularies in laudation, when we scarcely know what we are talking about. But it does not take an extreme optimist to believe that the great and good people have not all disappeared from the earth, and that their posterity are not all inferior and deteriorating. Without taking into account the scum and driftwood of society, notice the position of young America as a whole.

It has been said that the chief corner stone of a nation is the hearthstone. Then our national corner stone is the nearest perfect ever yet found. With houses all that science, art and skilled labor can make them; with furnishings and conveniences to make all comfort and save much labor; with cooking reduced to a science, and eating to an art; with books and papers for all, and time to use them; with music and healthful amusements; with everything material that brain and hand and money can produce,-where can history show its equal?

Not far back we find no schools for the masses. Yet we do not remark at the idea of having a college on every hilltop and a school house in every valley, where boys and girls, black, red and white, may be educated as far as they desire. Our own grandmothers saw little of their brothers after school days began until marriage brought them together again, - the boys educated at college, the girls over work basket and kitchen table. Now brother and sister go up the hill of learning together. He carries her books and she helps him with hard lessons, while she is awarded the Torrey prize at Harvard and outdoes the senior wrangler at Cambridge. She takes physical training as well as mental, and from her 
complexion, figure and activity it is evident that she is not deteriorating. Boys and girls stand side by side in class room and on play ground, and their clear brains, broad chests, firm muscles, and whole physique promise the emancipation of a race from much of its former weakness and affliction.

The effects of modern education appear prominently in social life. Girls have acquired strength and individuality that give them the name advanced, and I believe they are just as gentle and ladylike still, though they make little tatting and talk much sensible truth. Their brothers are modest, sensible, brotherly fellows, with just as much wit and gallantry and more real manhood and purity than had the knights of old. They are not loungers nor dandies. Someone has said of the American gentleman, "His wholeheartedness, his broad, liberal thought, his nobility of soul are a glory to the nation and an honor to all mankind." The American woman believes that and tries to deserve her place beside him. And so equality in society - the narrowing of the difference between social requirements of boys and girls, is elevating both.

In the business world able men are needed to carry on the work of our fathers, and the right young men are ready in schools, on farms, in office and factory and shop and store - ready to make the country more prosperous still.

In public affairs the men now gone have made us great, and now our brothers are ready to do their part in guiding the ship of state safely through peaceful seas and possible storms. With the demand will appear men as grand and powerful as our Washington and Hamilton and Lincoln and Webster and Clay, from those who find in their names inspiration to higher thoughts and stronger efforts. With another war our brothers would fight as bravely and as well as any men of former days.

The young woman has a large field in which to use her power and ability. She is not clamoring for suffrage, but she takes an interest in public affairs, chooses and makes her career, earns her money, sees the world, and doesn't have to marry for money or protection. Still she makes the more devoted helpmate, efficient home-maker and womanly woman.

As we look around, we see from what fields are to come the men and women of to-morrow, in every department of life and work. 
Looking back from the heights where we stand, we may say with another, "We need no sign in the sky to assure us that a power greater and a plan more far reaching than any of man have been concerned in the progress;" and looking forward toward a new century, "it does not seem presumptuous to expect that consummations are still to be reached more delightful and stupendous." Make the picture what you will. Look through the coming years and see in America " the true home, the pure church, the righteous nation, the great, kind brotberhood of man." And then with such an ideal to be reached and kept by young America collectively, we may find inspiration for our individual living and thinking and working; and when our country is given the praise and honor due it, we, having done our part, may make an honest claim in saying, "We, too, are Americans."

How dear to our hearts are the memories of Ag. Chem.,

Which tells us how turnips are properly grown,

Where Prof., with his bald head and the book he puts grades in,

Was worried by notes in the dajs that are fiown.

We studied of drainage, of tillage, of composts.

of everything horrid the author could say,

Till at last the term ended, and with it our sorrows,

But the memory will linger for many a day. 


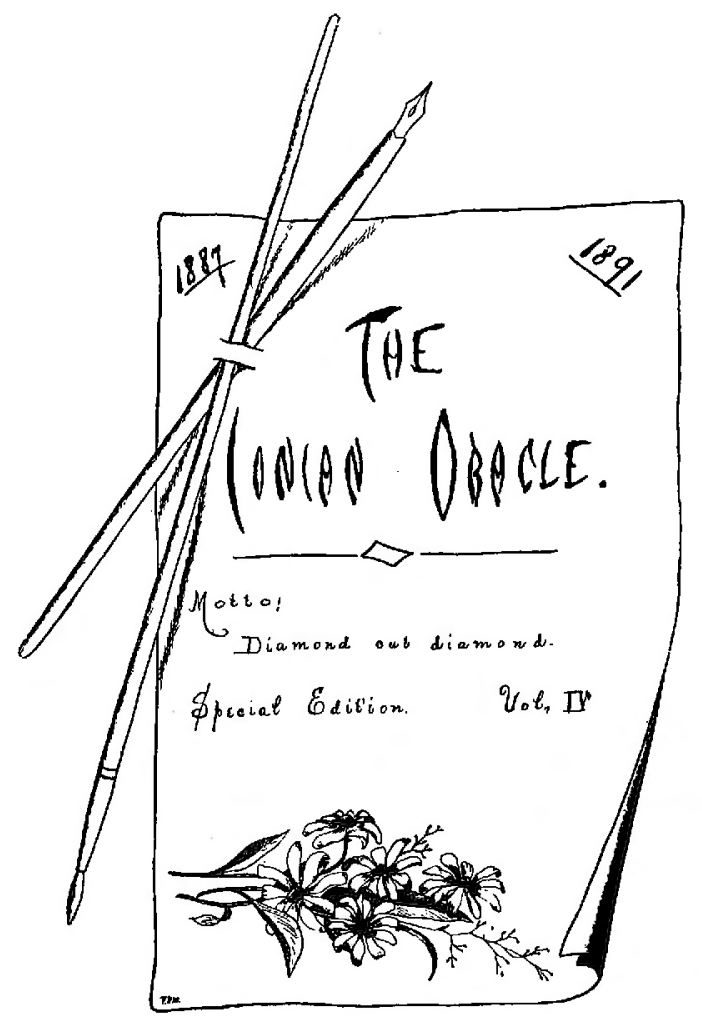




\section{THE MUSIC OF LIFE.}

Do you hear that simple music, that rippling melody? 'Tis the mind of a little child growing. Music is crude, the harmony is not complete; occasionally there is a discord. The air is simple, very simple. But as his horizon widens instruments are added and it becomes a symphony, simple yet, but growing musical. Thoughts are added, experience comes, and the player becomes more skillful.

As a child emerges into youth, the chords strike fuller tones, the harmony is richer, sweeter; he hears the sweet alluring melodies of love. The tinkling notes of laughter; above and louder, the martial notes of ambition cause him to step quicker and his face to flush with honest hopes; behind it, pervading all, are the harmonious undertones of hope and mother's love. This grows fainter as the clash of louder instruments break on the vibrating air.

The boy is a man, the whole orchestra is playing its loudest, fullest notes. There is the clash of the business world, the shrieks of the pipes and flutes as the struggle for rights and existence goes on; the groans of the bassoon as they rise and fall with success or reverse. At first this is all that the ear catches. As you draw nearer you hear the fuller cadence of friendship and morality. "Love took up the harp of life and smote on all the chords with might." A fine ear may hear still sweeter and sadder notes. "If singing breath and echoing chord to every human pang were given, what endless melodies were poured - as sad as earth, as sweet as heaven." The music is now sweeter, softer; no clashing of cymbals, but an even, full tone. But soon one instrument after another grows harsh, makes a discord and is silent; the others play on a sweeter cadence, seemingly trying to recall the melodies of early life, but succeeding only in a peculiarly sad music of their own, growing fainter and fainter, but sweeter still - then all is silent. As sounds of nature are caused by vibrations of the air, which widen out until they are beyond the scope of the human ear, being too high or too low, they are still vibrations, and travel on from universe to universe; so the music of life, though extinct to our ears, is still vibrating its influence on and on in an ever widening circle. Perhaps it is heard in heaven.

Julia Pearce. 


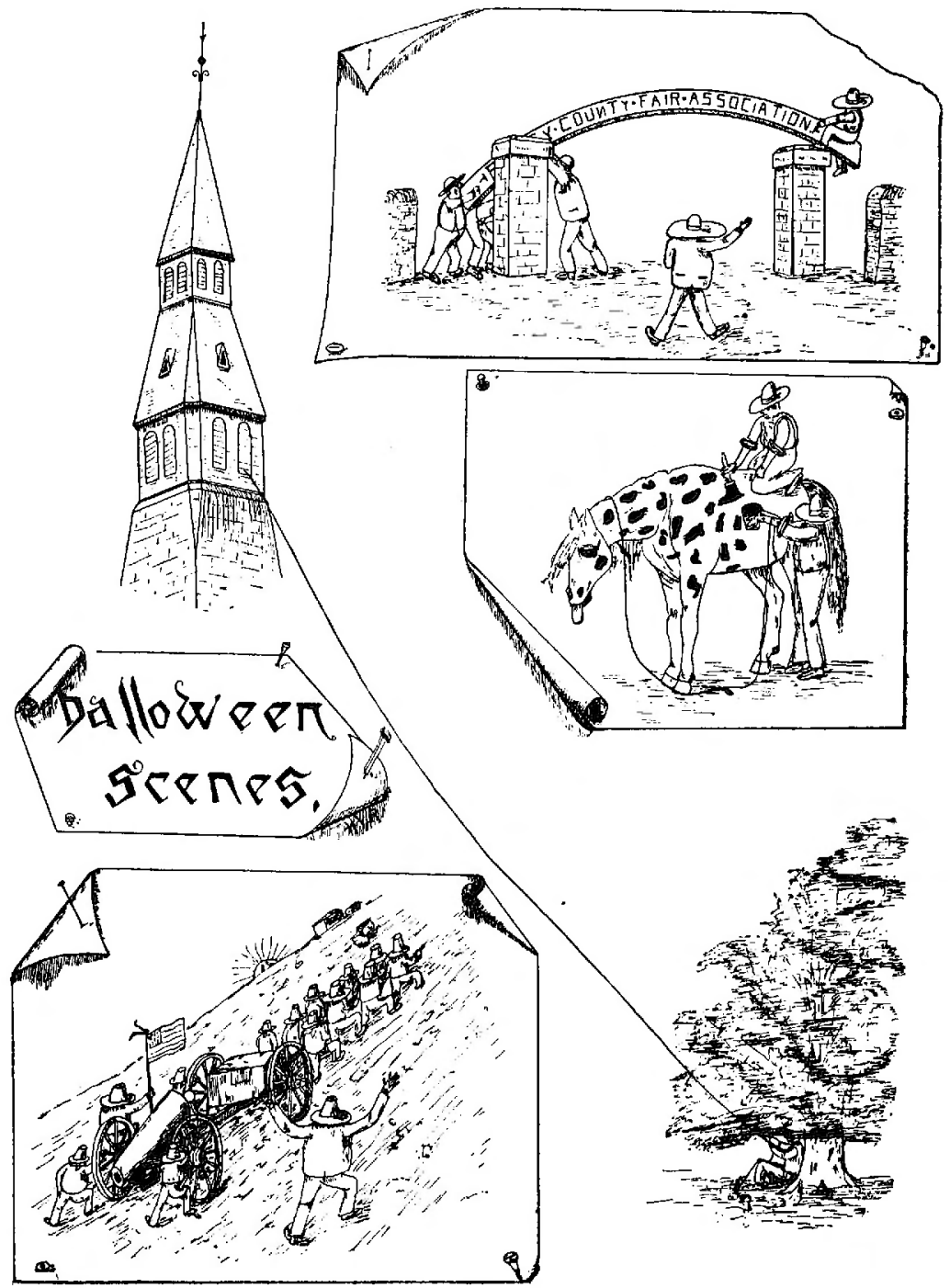




\section{THE HAMILTON POETRY GRINDER.}

As I was editing the Oracle once, I came to the "poet's corner," but the Ionian poetry machine had for some time past been sadly in need of repairs because of almost constant use by previous editors. So, when I took hold of the ever faithful crank, confident of hearing some sweetly melodious rhyme, I was horrified and astonished to hear only,

"Of all sad words of tongue or pen,

The saddest are these, "It might have been.'"

With a sneeze and a choke, followed by a low, sad sob, it sank to silence-"silence kept forevermore." All was darkness; the future was all a blank to me. I sat upon the floor and shrieked and moaned and tore my hair, but all to no avail. The same oppressive silence was unbroken save by the loud beats of my heart. Suddenly I heard a step upon the stairs; some one was coming. I hastily stuffed the poor grinder under my apron, and assumed a sweet, winning smile. An idea, a bright idea, had taken possession of my soul. I would borrow the Hamilton's grinder. I poured my woful story into the marshall's sympathizing ears, and by using a few briny tears as a clinching argument, I gained the grinder. $\mathrm{O}$ ! now I was happy; and with profuse thanks, I hurried home, faithfully promising to care well for the precious object. The kind marshal had given me a list of the subjects on which the machine would work, so I sat down and joyfully chose "Who was it?" turned the crank, and out came, .

"Who was it rang the college bell?

Who was it made its music swell?

Who was it bound us in its spell?

You tell! You tell!"

How provoking! I had certainly expected to hear who it was that had so disturbed our slumbers. I started again, "The Junior."

"How dear to my heart are the thoughts of the junior, When fond recollections recall him to mind. The junior, the junior, the huge pompous junior, The dear little junior who-- who- who."

Then a dead stop. Well! Well! Perhaps the grinder had turned that out too often already. Surely the Hamiltons haven't 
used the "I want to be an angel" tune much; but I am mistaken, for out comes,

"I want -- - to be - - a Hamp (cough)

I want - - to be - - a Hamp (try again and see if you can't get a little further).

I want - - to be - - a Ham - - ilton,

And with - - their lord - - ships sit;

A real - - idea - - within - - my brain,

A song - - upon - - my lip."

This is terrible--sit and lip. I haven't any decent poetry yet. "Spring."

"The balmy days of spring have come,

The sweetest of the year.

While flowers bloom so bright and gay,

We'll dry up every tear."

That's not my style of spring poetry. It won't do. Try again. "Sorrow."

"When apple trees bloom and mocking birds sing,

My old sorrow wakes and moans,

For I know the green apples those flowers will bring,

And bring from my lips most heart-rending groans."

'Tis too affecting. Try "The Serenaders."

"The serenaders came one night

And waked me from my slumber,

But when I threw the boot-jack out,

They saw they'd made a blunder."

Then it started off on

"England's son was slowly sitting"

but its voice failed. Regaining its composure, it began

"I cannot sing the old songs,

They are too old for me;

The Hamiltons have ground them out,

'Till chestnuts they must be."

Just here I would fain give up, but my chum pleaded for one more trial, and this is what we heard:

" $O h$ ! could I go to have some fun,

Perchance the P. M. ball,

I'm sure I'd see the faculty

A-staring at us all.

$\mathrm{Oh}$ ! could I go to operas

To see the players play,

l'm sure I'd see the faculty

A-gazing down my way. 
Oh ! could I on my couch recline,

To dream of how I'd shirk,

I'm sure I'd dream the faculty

Were telling me to work.

Oh ! could I wish that I were home

When failures make me blue,

I'm sure I'd feel the faculty

Were wishing of it too.

Oh ! could I never shirk my task,

Could I my race well run,

I'm sure I'd hear the faculty

A-telling me "Well done."

$\mathrm{Oh}$ ! could I rise to worlds unknown,

And join the heavenly throng,

I'm sure I'd hear the faculty

A-singing of the song.

Oh $!$ could I seek the judgment throne, And hope reprieve to find,

I'm sure I'd see the faculty

A-tagging on behind.

Yet could I prove my record good,

And gain eternal rest,

I'm sure I'd hope the faculty

Would be among the blest."

This last effort proved too great a strain on the grinder, and with one final squeak it gave up the ghost. ANNA D. F.

\section{CHRONICLES.}

Now it came to pass, that when the Ionians had been thirty months in the land, they conceived the idea of sending messengers to some wise speaker to come among them and to teach the people in the synagogue; but a ruling bad lately been made in the land that this could not be, for all the tribes about could have but one man to come and talk to them at the time set for the people to assemble.

Now to the south of the Ionians dwelt a mighty race of men, known in the land as the Websters. These people were exceedingly great and had waxed fat in the land many years, and among them were men that had grown old in war. Now these people said 
among themselves " $\mathrm{We}$ are great and our numbers are exceeding; nowhere in the land can be found such valiant young men, ay, nowhere." And one tall, fair haired youth arose to address the people, saying, "To the north dwell a puny race known as the Ionians. They are all girls and know not what they do. It is not mete that they join us in this thing." And the king was well pleased, and said, "It is well. We and the tribes about us will unite, and the Ionians will not be with us." And they strutted exceedingly, and thought themselves "some pumpkins," and they were right.

But verily, verily, I say unto you, that he who planteth his pumpkin seed hastily and covereth them over exceedingly deep, will have no vines, and his field will be as the stubble that beareth no fruit, and he shall be like unto the Websters. But they will be like unto the Ionians who put their seed in good soil, few in number and covered them so light that the sunshine of generosity could shine through, and they grew, and behold the fruit yielded in its season.

So the Websters rejoiced in their iniquity, and the day drew near when the selection should be made, who should come and speak to the people; when the voice of the most high ruler was heard, saying, "Hearken ye, my children, unto my voice, for I say unto you this thing cannot be, for unless you have the Ionians with you your speaker must not come at the time the people assemble."

Now the Websters were exceedingly wroth and knew not what to do, for they would not let the tribe be with them, and they held much high debate and stood back some weeks or more. But they knew it must be, so their chief ruler George the Infant, the gayest and prettiest young man of all the tribe, went forth with three others of his most tried and truest followers; one tall, warm-tinted youth, and the man who had made speeches to the people bringing them into trouble, he was there, and they went forth to the land of the Ionians with much trembling and trepidation, but the Ionians said, "We will treat these men as strangers, for they now bring and offer us the meat that is ours by right, and we will take and eat, but offer them no recompense." And it was even so, for the maidens went about their work and heeded not the mighty Websters in their midst, and they at length rose in much anger, de- 
parted the way they came. Now when they were gone the Ionians rose as one man to consider the question and to decide what they best do, for they were a wise and a forgiving people, and they hated this thing that had caused their neighbors trouble. And it came to pass that they sent messengers running in great haste to all the tribes saying: "We send greeting to our brethren and wish peace among the people, and we would that they be not troubled concerning us." And the tribes said, "It is well."

Julia Pearce.

"OH! YES, HE'S DEAD."

The cat is dead; that good old cat

We never shall see more.

The third-year girls dissected him, His furry coat they tore.

His heart they opened to the day,

His lungs they brought to view;

These cruel girls without dismay,

Did stick him through and through.

Then out they gouged both of his eyes,

They cut off both his ears;

And yet they heaved no long-drawn sighs,

'They shed no briny tears.

Kind looks he ever had for them,

Nor knew their base design;

Why should those girls, those wicked girls,

To cruelty incline?

He lived at peace with all mankind,

He no disturbance made;

No man e'er rose, his boot to find,

To stop his serenade.

But now he's dead. Oh! yes, he's dead;

I tell you 'tis a shame.

Poor fellow, he for science bled,

In glory write his name. 


\section{OUR STATE FLOWER.}

We have heard so much discussion in regard to our national flower, whether it should be the rose, the clover, or the goldenrod, that we have not given any attention to the flower of our own particular commonwealth, the symbol of the State of Kansas.

Although so well known, it seems to us that the sunflower is not properly appreciated. To the botanist it is only one of the large order compositx, difficult to analyze and impossible to press. To the farmer, it appears as an annoying weed which disfigures the borders of his field. Some people have been heard to remark "this will be a sickly season; there are so many sunflowers, and that is a sure sign of ague." Others regard it as a great, coarse plant, useless, because devoid of grace and fragrance.

Did you ever wonder why the sunflower was chosen our State flower, or note some of the useful lessons to be learned from this common, homely plant? The sunflower seems to me a fit emblem of so great a State because of its "staying" qualities. It possesses the first secret of success, for no matter if it is cut down or choked back, no matter how wet or how dry the season may be, it overcomes all obstacles, and like the true Kansan that it is, puts on a brave front and keeps on doing business at the old stand.

It possesses the hardy nature of the pioneer, and the honesty of one too, for it lifts up its great, bright face and looks you squarely in the eyes. Like the characters of our countrymen, it is more durable and useful than showy or elegant, and the beauty which it possesses is not of the frail and fleeting sort, but the beauty whose merit lies in the comforting influence and cheering association with which it impresses us.

What if it is a common roadside flower? It blooms all over our broad State. Where is the person that is not glad to see its familiar face where all else is strange to her? We are glad to know that the sunflower thrives in the vacant lots and country lanes about Manhattan. Let them grow and nod in the autumn sun. Their bright, homely faces seem like faces of old friends, and we feel less homesick when we see them smiling upon us from the highways and byways. Einulate this sunflower, my dears, and like it always keep your face towards the sun, and our State will be, in more senses than one, the "Sunflower State."

EFfie Gilstrap. 


\section{NOVELS' HEROINES.}

For two hours I have been in England with the beautiful heroines of an English novel. As I finish, and am called back to prosy old Manhattan by the "finale" on the last page, I throw down the book with a yawn and exclaim, "What a silly girl," and then I fall to thinking about those foolish beings, and about other girls in books I have read. How few of them are like girls that I know! pretty little creatures, cute, picturesque, useless except to break men's bearts-girls with slender forms, golden curls, deep violet eyes, dainty feet, clinging draperies, etc.

Another class, equally rare among girls I know, but more to be loved, are the beautiful young women having all the queenly graces that we most admire, always knowing and saying and doing the right things at the right time.

Not all heroines are like either of these, however, and it is indeed refreshing to find a story of a more common sort of girl. When we read of girls that have our trials and pleasures, temptation and perplexities, the story becomes more than a story to us. No need to ask why girls, young and old, love Mrs. Whitney's and Miss Alcott's stories. Their girls are giris that we know.

I wonder how some of the Kansas girls that I know would appear in a novel; imagine a minute: what if some girl, not an Ionian, should some day find herself a woman with the power to use her pen well, as so many others have? Had she the power to see the characters, feelings, and the hearts of these girls we know, and the genius to show them to others as they are, would they not be more interesting to us than any story of beautiful belles of New York, or London, or Paris? I hope some one will write a novel some day about some of our Kansas sisters, and let us see how they will look in a story. The romance would not be lacking, and we would find much to admire and love, although the girl be neither a beauty nor perfectly adorable.

Gertie Coburn.

\section{PARASITISM.}

Parasites are the most degraded and despicable forms of nature. If you ask the biologist why, he will tell you that they have committed one of the greatest crimes of nature. They have evaded the law of the struggle for life, and are almost a breach of that 
greatest of laws-evolution. This law demands the highest development of all the faculties in order to attain the nearest possible perfection of the individual class. Let us see how nature avenges herself on parasitism. Go to any extensive work on zoölogy and you will find numerous instances of animals which bave once led a free and independent existence becoming parasites, or if not true parasites, seeking home and safety at the expense of some other animal, perhaps inhabiting his cast off shell.

In all the cases you will also find that there has been a gradual degeneration of the animal, either manifesting itself in the individual or in future generations. But the more particular study for us at present is that parasitism which is exhibited in the highest animal form, namely, man. Here, as before, parasitism implies a lack of exercise of those faculties which are given us to procure our safety and food, be that food physical, mental or spiritual. 'Here also, in accordance with a law of nature that nothing shall exist in vain, a lack of use means inevitably deterioration and final atrophy of those neglected faculties. It is true that the exertion of getting food is but a means to an end, yet in the economy of nature the means are quite as essential as the end to be attained.

Of our physical, political, or social parasites we have no need to speak; they are all too readily recognized. Our mental parasites, though not so easily known are quite as numerous. They never study alone if they can avoid it, preferring to get some one to help them. They never have any opinions of their own. $\mathrm{Oh}$, no! theirs might be too crude. They simply adopt those that they have heard expressed by the majority. They even come to our societies, where they try to escape every duty laid upon them and rest content to reap the benefit of others' resources. Our moral parasites are even harder to distinguish. Their opinions of right or wrong are derived from the society in which they move, and if they have any qualms of conscience they are easily quieted by reflecting on the seemingly greater sins of others. But we have reached the highest faculty of natural man, and as we enter the spiritual world can we expect to find parasitism still in existence? Sadly we will have to confess that here it is abundant. For example, our church goer who goes because other people go; also, our dead church members who allow their preachers to do all their praying and Bible reading 
for them, and yet vainly imagine that because they have once joined the church they are on the straight road to Heaven.

But after all these people need not worry, as it is themselves that they injure. Still, we may profit by their example, and when we are tempted to take the easy way out, remember the punishment that inevitably follows nature's laws. "Better far," says Drummond, "to be burned at the stake of public opinion than to die the living death of parasitism."

Maude Sayres.

\section{A DROP OF INK.}

A drop of ink is a very minute portion of the fluid by which thought is transported to the reading world. And yet what vast possibilities are encompassed in one little drop of ink! It may inscribe the words which shall decide the destiny of a life, making it blissful or wretched. It may send the sweet message of friendship or love which shall cheer the lone toiler in life's uneven journey. It may paint in such glowing and fascinating colors, the way of truth and righteousness, that the skeptical may be led to walk therein. It may send an order to advance an army and save a nation. It may sign the death warrant of the innocent, or send pardon to the condemned. It may pass an unjust criticism upon a young genius aspiring to literary or musical distinction and blast his hopes forever, or it may convey to him the word of praise that will stimulate his heart and brain until success is attained. All the powers of thought cannot enumerate the possibilities of one drop of ink; they are far too numerous. Let us not despair if, in our hearts, we desire to do good and speak for the right, but use the drop of ink and wield our pens for truth and justice.

Aun Rice. 


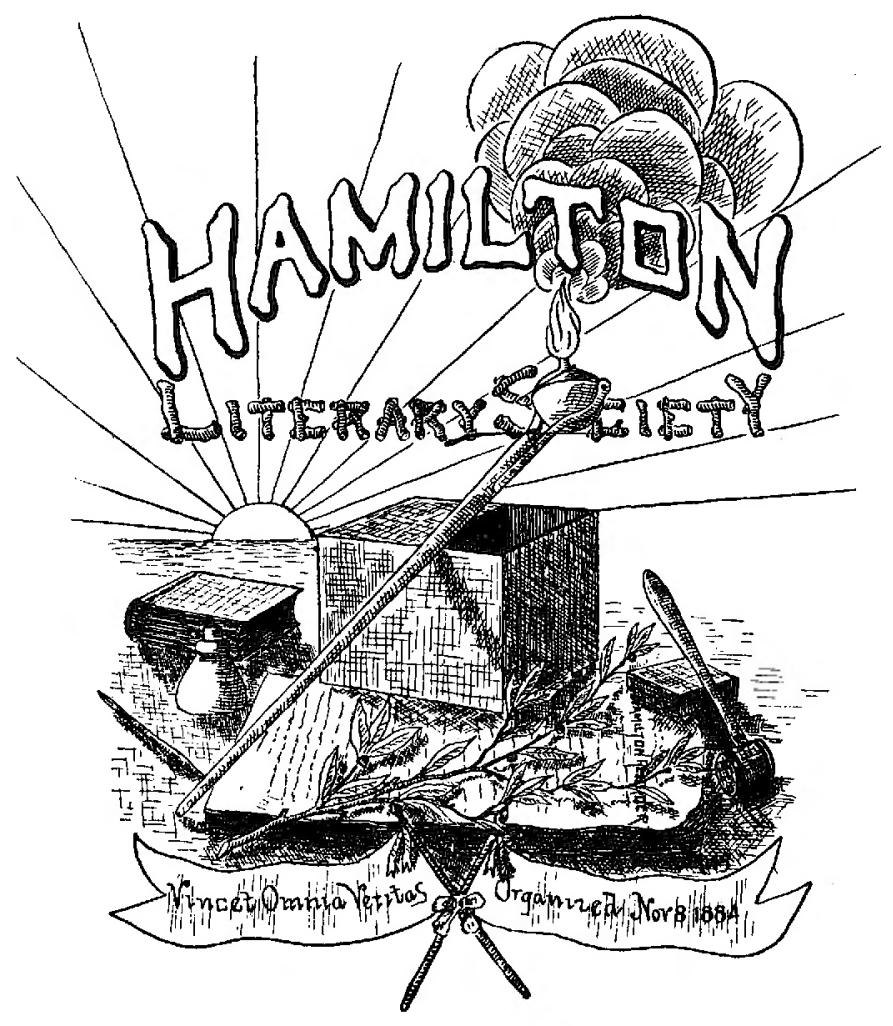




\section{HISTORY.}

From the establishment of the College the work of the literary societies connected with it has supplemented the instruction given in an admirable manner, and has given to those sharing such work an application of principles and a training in methods which the work of the class room cannot provide. The member of a literary society is brought in direct contact with his fellow students, and free from the restraint he always feels when in the presence of an instructor, he is taught to control himself, to measure his ability by the standard of what others can do, and to be always alert, ready alike for defensive or offensive battles. He gains an effectiveness in the use of language which the study of rhetoric cannot give, and a method and self command in speaking which class work in rhetoricals will not impart. Besides this he is trained in the order of business, and is strengthened by the responsibility of making the society work a success. For all these reasons the earnest students have at all times been enlisted in this line of work, and as the institution has grown in size, the interest in the literary societies has increased.

The last decade has been one of unusual prosperity to the College. It had not balf passed away before it became evident that the old societies did not furnish sufficient training to their members on account of the large membership. It was therefore thought best that a new society be formed, and on Saturday evening, November 8,1884 , a small body of young men met in the old north corridor and pledged to such an organization. At a second meeting, held November 15th, a constitution was adopted; with the enrollment of sixteen members, and the election of officers, the organization of the Hamiton Literary Society was completed. It was a small membership to begin with, and there were many difficulties to overcome before the new society could take rank with the older ones, but the men who founded it saw clearly the character of the work that would succeed best, and so well did they do their work that little of it has since been changed.

During the following term the membership increased rapidly, and it was not long till it reached the limit which was placed upon it during the first three years of the society's existence. Its work from the first has been that of a literary society, and the programmes 
have consisted of declamations, essays, orations, music, debates, and the bi-weekly society paper, the Recorder. Special attention has been given at all times to extemporaneous speaking, and various methods of training have been pursued. At first questions were distributed upon which members were expected to speak; then assignments were made for the duty, the speakers selecting their own topics. But the most valuable training has come in the discussions under the orders of business, where the drill in speaking combines with a training in parliamentary law. The parliamentary battles have always been a favorite practice in the society, and have given it an enviable reputation for thoroughness and accuracy in such work.

Until the fall of 1889 the society met in "Corridor D." At that time a new room was assigned to the Hamilton and Ionian societies, and by their efforts the room has been neatly furnished, and affords a pleasant place of meeting.

The first public entertainment of the society was a lecture by Prof. James H. Canfield, in April, 1886. In February, 1887, it gave its first and only special session, followed in March, 1888, by its first annual exhibition. These annual representations of the society's literary work have always given satisfaction, and rank well among that class of public entertainments.

The growth of the society has not alone been in the increase of numbers, but is manifest in every line of literary effort.

\section{PRESIDING OFFICERS OF THE HAMILTON SOCIETY.}

1884-85-T. Bassler, T. Bassler, G. W. Waters. 1885-86-E. H. Perry, G. W. Waters, N. E. Lewis. 1886-87-E. B. Colburn, J. H. Criswell, S. S. Cobb. 1887-88-A. Walters, A. E. Newman, A. C. Cobb. 1889-80-F. A. Campbell, E. M. Paddleford, S. I. Borton. 1889-90-G. J. Van Zile, S. L. Van Blarcom, A. F. Cranston. 1890-91-B. Slinner, H. B. Gilstrap, H. E Moore. 
ROLL OF MEMBERS.

'91.

W. A. Anderson,
R. J. Brock,
E. C. Coburn,
H. B. Gilstrap,

C. P. Hartley,

I. B. Purker,

C. J. Peterson,

W. S. Pope,

C. Abbott,

E. M. Blachly,

W. V. Hester,

C. R. Hutchings,

S. B. Johnson,

R. B. Abbott,

O. C. Axtell,

G. G. Boardman,

J. M. Calhoun,

G. Doll,

J. Dougherty,

H. E. Downing,

S. V. Hogbin,
G. V. Johnson,

F. M. Linscott,

A. E. Martin,

A. Midgley,

92.

A. D. Rice,

W. J. Town,

R. L. Wallis,

D. F. Wickman,

93.

R. Laundy,

T. E. Lyon,

G. T. Morrison,

H. R. Phillips,

J. D. Riddell,

94.

A. Jackson,

W. J. Jennings,

A. Johnson,

I. Jones,

Wm. Joss,

C. D. McCullough,

D. H. Miller,

S. Olmstead,
H. E. Moore,

B. Skinner,

S. L. Van Blarcom,

F. A. Waugh.

G. W. Wildin,

C. E. Yeoman.
J. A. Rokes,
F. R. Smith,
W. E. Smith,
W. O. Stover,
J. Sutton.

O. A. Otten,

J. H. Persinger,

W. F. Redenbaugh,

J. A. Schiel,

R. Simmons,

T. H. Smythe,

W. W. Watson,

E. Wood,

F. Yeoman.

\section{SCIENCE AND RELIGION.}

[Oration delivered by A. F. Cranston at the Hamilton Annual, 1890.]

Every age of the world has had some specific character - some sign which marks its unit spirit has surged high and assumed a form of fanaticism, as is shown in the crusades and the religious wars of Europe.

The ancients were distinct from the moderns. Their civilization was of a tangible, material character. At mention of Egypt our mind rises instinctively with the pyramids, and the fertile valley of the Nile, loaded with the spontaneous products of a tropical zone, spreads itself before the senses. At mention of Greece we stand in admiration before the parthenon and build a dream in the age of Pericles. Carthage, maritime Carthage, her 
harbors bristled with the spars and masts of a thousand merchant vessels, and, until her magnificence tempted the Roman legions, the Punic basked beneath a luxuriant meridian. Rome, armor clad Rome, with sword and battle-ax, she bewed out the haughtiest republic that has been.

Look at these, they each have shown a rise and fall, a life and a death, yet each is a tragedy in itself.

Since the fall of the Western Roman Empire, three ages in succession have unfolded themselves - the ages of religion, reform and reason. We are now living in the age of reason or science. What a grand one it is -.."The sum total of all the past."

Science has given to the modern mind a depth of penetration, a keenness of observation, and an accuracy in experiment which has never before been known. What has it done for civilization? In the sixteenth century Copernicus proved the falsity of the Ptolemaic theory of the heavens. In the seventeenth century Gallileo made his renowned discoveries among the stars. Harvey discovered the circulation of the blood. Bacon substituted the inductive for the deductive system of philosophy. Kepler founded mathematical astronomy, and Newton discovered the laws of universal gravitation. In the eighteenth century Franklin applied electricity to the arts and drew the lightning from the sky. Linneas classified plants and laid the foundation for modern botany. Priestly discovered oxygen, and Herchel improved the telescope.

Now what does this mean? It means that progress has at last wheeled into the right path - a path which man has been blindly seeking since he first began to think. It means that lightning is a phenomenon of electricity and not the wrath of angry gods; that the sun is the centre of revolution of planets and stars, and that our earth is but a dust-mote glittering in his rays; that the abolition of slavery is due to the application of steam to machinery; that energy is convertible into heat, light and electricity; that man thinks more and knows less, earns more and works less, loves more and hates less, worships more and prays less than in any other age of the world.

The millennium may never be reached - science may never be able to prove or disprove the existence of matter, to affirm or deny the freedom of the will, to analyze material and mental energy, 
motion, sensation and volition, but it has deduced laws which, if obeyed, will ameliorate man's condition upon this earth.

Some have charged scientists with fallacious reasoning and illegitimate applications to religion. Others have declared science a species of heresy. This is ridiculous and a mere presumption of ignorance. Who knows better than a scientist what truth is and what is its value? There is no baughty pride, nor pompous declamation, nor dogmatic omniscience about the true scientist. $\mathrm{He}$ is meek in heart and humble in spirit. He is the champion of truth and the sleuth bound of error. Science ever seeks to maintain the "accurate," and throws around philosophy the limits of the known. Without science, religion is apt to run into fanaticism and superstition.

Scientific men are apt to be moral, for their ambition ever reaches for the true, and he who will not accept a logical conclusion, be it in harmony or not with supposed inspiration, is blindhopelessly blind.

There are irreligious men in every church and very religious men in no church.

There is a scientific religion that is neither agnostic nor dogmatic, there is a scientific morality that is neither altruism nor egotism. The church should bring religion down from the imperial realms of the infinite, about which we know nothing, into the kingdom of the finite, about which we may learn something.

Then why this casuistry about original sin and redemption, about primeval life in the garden of Eden: it seems but the fairy frost work of fancy. Have a religion that drops a penny into the hand of the beggar, that strolls in the fields in summer, that glides over snow and ice in winter.

The boundless fields of sky, the sun, flying meteors, the eternal march of the seasons - dark forests full of wierd voices; volcanoes, caves and cataracts, glaciers slipping down the mountain, fountains springing up in deserts, rivers running under ground, life surging along the streets of cities, death sleeping in the graveyard - these are for your study and your admiration - among these you must build your heaven or your hell. 
OUR HERITAGE.

[Oration delivered by Ben Skinner at the Hamilton Annual, 1891.]

Although made narrow by superstition and suppression, the ideals of our ancestors, when they settled on the broken shores of the Atlantic, were liberty and progress. Old customs steadily gave way before the pressure of new conditions, and with the closing scenes of the war that gave us a race problem, we find this people, after having shed rivers of blood in checking the wrongs of nearly four centuries, happy in the belief that "king or congress could no longer handle them as pawns on the bloody chess-board."

Slowly, but surely, through all these years had men become broader, wiser, more humane in their views, and to-day, bound by the ties of philanthropy and national unity, we stand on an eminence that overlooks the range of nations. Proud of every attainment that has helped to make us what we are, we review the past with pleasure. Yet, carried so far from the scenes of bitter strife, we think little of the suffering, the misery, and death that these grand victories have cost. We feel that the right has conquered; and are content to know that from the first settlement to the present, these treasures have been handed into our keeping; while we, seeming to disregard the obligations that come with every advancement, give our support to a system that builds up a few to the sacrifice of many-a system which gives to a Vanderbilt wealth beyond the dream of avarice, and condemns the poor to poverty from which there is no escape but the grave.

Shall we be satisfied to continue on this plan, enjoying the labors of others, robbing the multitude of their sustenance, without waking to the fact that we owe to coming generations an untarnished addition to our heritage? No! Progressive action is demanded of us as much as it was of our fathers. Why should we be content to follow in the ways of a preceding generation, when the conditions that are beginning to present themselves call for less corrupt legislation, better regulated and better enforced laws?

We condemn slavery, where here within the memory of millions, it has been associated with the most gaudy ideas of universal liberty; even defended for years by a majority as right. With the advance of the country old customs have sunk into the background. The tendency of the nation is still forward, and just as 
popular opinion went against the mother country and slavery, so now is there a growing feeling against. present legislation. Some pessimistic minds even evolve the theory that we are drifting toward inevitable destruction, that the signs of the times portend a greater disaster to us than has ever befallen a people.

Why need such thoughts disturb the peace or happiness of any sane American? We are the government. In our hands, by the right of suffrage, is placed the lever that regulates the movements of the nation. If we, allowing our minds to become overshadowed by the prejudice of former days, follow the example of the drunken engineer who guides his mighty steed to destruction, whose fault is it?

Those unbiased, noble minded men who framed our political foundation, foresaw the necessity of change with new conditions, and made due provision by which the destruction of life and property, that we have already suffered, could have been averted. The laws of the country are even more amenable, and are now, as they were then, in the hands of the people to model. Shall we model these laws to meet the new conditions that are presenting themselves? Can we afford to ignore the lessons that through the ages have accumulated in the experience of men, to violate the great historical laws that show the necessity of justice, and still expect to go on, by some inherent quality, surpassing anything that has been achieved, without paying the penalties of the ignorance of truth, or the wantonness of error.

It is one of the unpardonable vanities of the people of this country to hold that our land is so favored that, no matter what is done, we shall forever have advantages warranting us in perpetual profligacy. The present condition of affairs proves that something is wrong. The people do not array themselves in antagonism to fixed principles without a just cause. Discontent and corruption are abroad; political campaigns have become, instead of a test of principle and virtue, simply demoralizing battles, with money and whiskey for arms; and demagogues are reaping a golden harvest. Laws once well suited to the development of infant industries of a young and struggling nation have become oppressive to the people. Corporations have flourished and multiplied. The baby we are rocking has grown to be a six-footer, and now threatens the home that has 
nourished and reared him if we refuse to continue. Foreign capital finds here a lucrative lodging place, and our treasury walls sink under the weight of the enormous hoards of gold and silver. These are the grounds on which the intelligence of the country proclaims continued peace and prosperity; but have we any assurance of it?

Ours is, indeed, a grand heritage, and by the manhood of America it must be kept pure; but may we, from our neglect of civil duty, never be called upon, as others have been, to purify it with blood. Nor need we be; for the ballot, if rightly used, is mightier than swords and muskets. Before it, without march or siege, intemperance and corruption may be made to flee. Then when you vote, do it intelligently, honestly. Think of the brave and good men who gave up their lives that we might enjoy this heritage, and fling aside the veil that seems to obscure the true features of the questions which you and I, within ourselves, must settle.

Remember, too, "we should be content to be the greatest and happiest of the nations, and find out before it is too late, without other tumults and wars, that there is no people so mighty that they can be unjust with safety, - that there is no fault worse than wastefulness of the substance of the earth we inherit, and no crime so perilous as to wrong the poor."

\section{HERE'S TO THE IONIANS.}

[A toast respondel to by H. E. Moore at a joint session of the Hamilton and Webster societies, Saturday, March 28, 1891.]

A few days ago when $I$ was informed that I must to-night respond to the toast of "Here's to the Ionians," I was totally ignorant of the character of such a duty, but after many weary hours of thought I came to the conclusion that my mission lay in complimenting those of the fair sex whose good fortune it is to bear the proud title of Ionians.

When I had proceeded thus far the question arose, why should I, a little, insignificant, dried-up and-blown-away Hamilton, be chosen from such an august body as our society, to perform a duty of which I knew so little? The answers came, two in number. The first to suggest itself was that this was an act of courtesy which we, as a society, owed the Ionians in a meeting of this kind-an act which partook more of the nature of a duty than that of a pleas- 
ure-something which all recognized must be done, but something which no one was willing to undertake. In short, one of the little things which I, by virtue of my office, (that of "old odd jobs") must perform. Another thought was that this was a duty of a very delicate nature; one which required the greatest stability of character to perform with "fidelity and impartiality," and that I, as the only loyal Hamilton who is absolutely unbiased in his opinions, was chosen as alone adequate to the task. That $I$ was chosen as the only man in college who could unblushingly stand up before such an enlightened assembly so well up in the ways of the world, and act as the mouth-piece for this, the Hamilton society, through which to pour forth its love to this, the Ionian society.

Now, after concerning myself thus far with matters of explanation and introduction, I think I may proceed at once to the point without any fear of being misunderstood. We regard the Ionians as our dear friends, and if I were to-night at home with my fellow Hamiltons in our little room up in the attic, I think I might be induced to lay aside formality and say that we love the Ionians. We love them both collectively and individually. I can't say which way we love them most. Some of the boys seem to favor the individual plan, but for my part I think I shall continue to like them in the good old way just as one, a unit. I may have had individual affections for an Ionian once, and may have contemplated making the fact known to the world by taking her to a social, but if I did, she, upon consultation, thought it unwise, and so it had to be otherwise.

Now, laying the matter of fun aside, we do have a kindly regard for these, our lady friends, and there are many reasons why we sbould. They, like ourselves, occupy a lonely, uninviting room in the garret. They, like ourselves, are young in society work, and must ever bear all the scoffings which Webster divines and Alpha Beta preps are capable of heaping upon us. As I say, the Hamiltons and Ionians are united in a common defense, but we, the Hamiltons, are the stronger, and feel ourselves called upon to resent any unkindly treatment which our fair sisters may receive.

A cruel Webster once said, "The Ionians are no parliamentarians,- of Robert's Rules they don't know beans." I am here to say that this is not true, and if anyone doubts my word just let him 
make a proposition to a fair Io. and see how quick she will "lay the motion on the table" or "object to the consideration of the question." Perhaps she will "refer it to a committee" of one-her ma. There is another point of parliamentary law in which the Ionians al. ways excel, and that is on the "previous question" racket. They can always work that on a fellow to perfection. Now, granting that the rash statement of that Webster was true, of what consequence can it ever be? Their relations to the world are not such that they must become masters of parliamentary law. Until there is a radical change in the policy of our government none of the Ionians will ever be called upon to stand up in the halls of congress and vie with men of ability over points of this kind. Their influence upon politics must ever be through the medium of their pens, and indirectly through their gentlemen friends, and this is the sphere for which they are now fitting themselves.

For purely literary ability, the Ionians stand where other societies, much more boastful and pretentious, cannot stand, and in the presence of their musical talent the other societies must hide their faces for shame. They have within themselves, as they have demonstrated on a previous occasion, the material out of which to make an exhibition that all must be proud of; an exhibition the good qualities of which others must admire but cannot imitate.

Now, taking it altogether, we think the Ionians are just about right, and when they shall have graduated and leave their beloved alma mater and the rest of us fellows, we think we can conscientiously recommend them to the world as subjects suitable for matrimony. That is to say, we hope and trust that by that time they will have gained sufficient knowledge to enable them to know a good thing when they see it.

REQUIESCAT IN PACE.

Tell no more, ye men of Kansas, Jerry Simpson wears no hose, For those jokes on sockless Jerry Follow one where'er he goes.

I have listened till I'm weary Of the man whose feet are bare, Of the man from Barber county With the hay seed in his hair. 


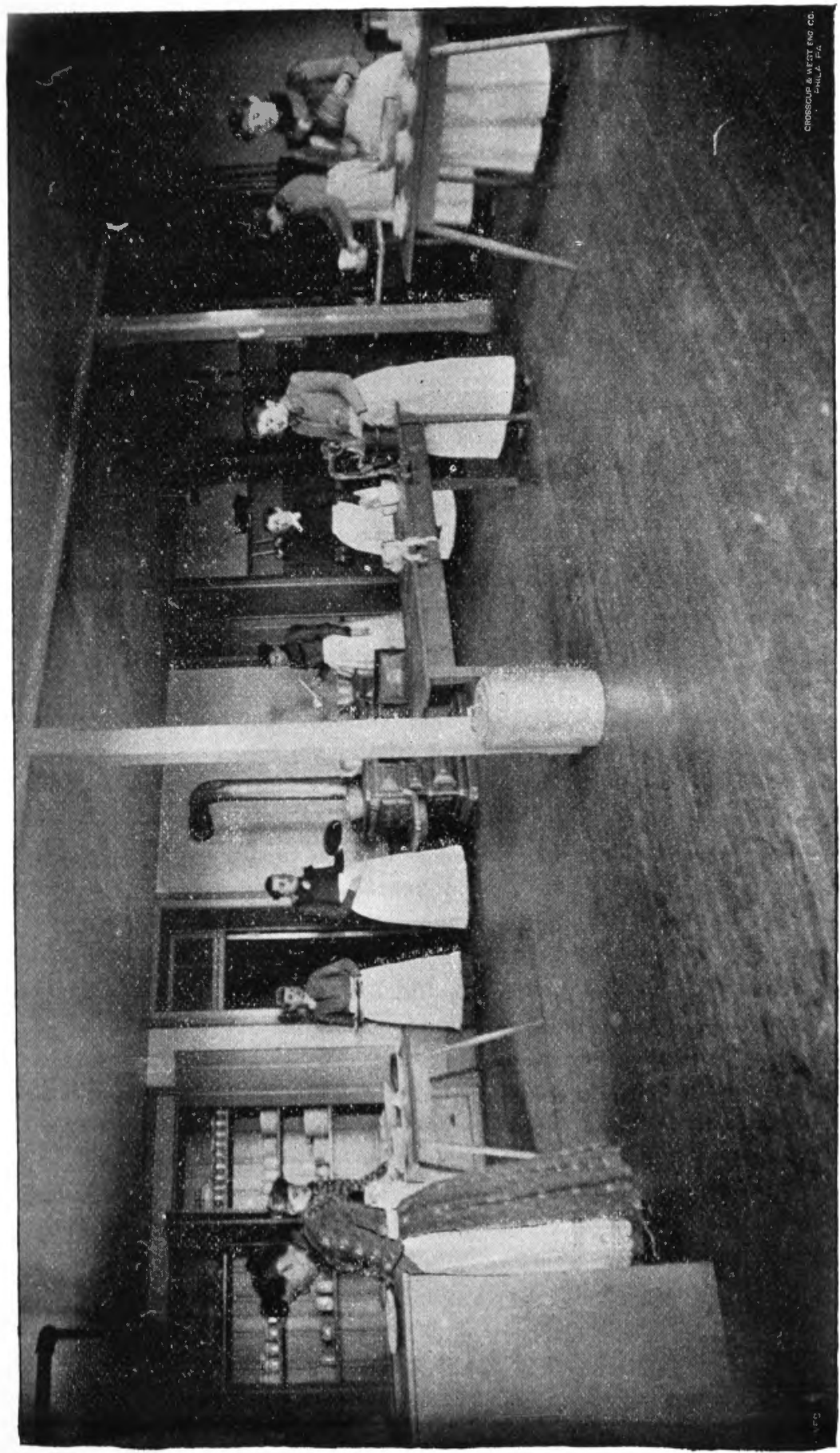

落 
Do not try to draw a picture

of this man among his flocks;

Do not show him as he studies

Up the tariff on our socks.

Do not show those horrid jimpson

Weeds that hide his humble cot;

Let these pictures, stale and weary,

Be effaced and be forgot.

All these things are too familiar

To the people of our State;

Tell us now some other story

That we haven't heard of late.

Since our Jerry is sojourning

Where the broud Potomac flows,

Show at least a little mercy,

And shut up about his hose.

H. B. G.

\section{A DEEP SEA ROMANCE.}

One morning as the mermaid started out from her aqueous couch to milk the brindle sea-cow, she became enraptured with the scenes about and above her. The sunfish had not yet come out, and all over the vaulted dome of the sea, the starfishes twinkled and told of the dying night, and they themselves died with the story they told. As she watched, enchanted, the day broke. The seabutterfly settled on the sea-anemone at her side; the sea-hare sought his dismal hiding place; the sea-lily waved in the sea breeze; the sea-lion roared in the distance, and hied him home, leaving the scene to gentler influences.

The mermaid was infatuated with the seascape. A now life seemed to have dawned upon her. She forgot the lowing of the patient sea-cow, except as it entered into the general harmony of the whole effect, and the plaintive bleating of the sea-calf failed to arouse her. While thus she mused, ready for any sensational event, there drove up to the door a brilliant chariot, drawn by six prancing sea-horses. The noble-looking driver tightened the reins and the obedient sea-horses stopped. Now it was his turn to be enchanted. He gazed for several minutes straight upon the beautiful mermaid before him. She felt the warm blood mantling her 
cheeks, yet she could not resent the stranger's undisguised interest. Gently he approached her and laid his hand upon her waist tenderly. "I have found," said he, "the one creature for whom I have searched the sea from shore to shore. Fly with me to other seas." Overcome with the ecstasy of the moment, she allowed herself to be borne to the waiting chariot, and while all her little brothers and sisters, (the dirty-faced little sea-urchins,) looked on; while the sea-cow still lowed from behind the bars, and the seacalf switched his tail to keep the sea-flies off, the mermaid eloped with a son of a sea-cook.

F. A. WaUgh.

\section{THE COLLEGE "JUMPING JACK."}

Did you ever see the student who is seeking an appointment on commencement day; who wants to teach the P. M. squads and take charge of classes when the professors are attending farmers' institutes? Well! that is the fellow we call the college jumping jack. We have seen the chap who wanted to be a U. G. sit in the class room like a bump on a $\log$, and for three long, weary years smile at the professor's every joke, agree with him in all his statements, and hardly dare to call his soul his own. Of course it is all right to copy after our superiors, but it is refreshing to see a student who has ideas of his own and the nerve to express them; who, when he does not see the point to a joke, does not laugh, and who speaks out when he differs from the statements even of a professor. By all means follow good advice, but don't be a faculty jumping jack, - don't fold your arms and flop your legs and grin and bow whenever the string is pulled.

G. W. Waters.

\section{PROFESSOR AND STUDENT.}

The professor is a person who may sit on the chapel rostrum during morning exercises; the student is a person who must hide a number on a chapel seat down in front. The professor is a man who has a chance to put down big O's when he asks questions; when the student asks questions, he has a chance to go to the Encyclopedia Brittanica and find out. The professors publish a weekly journal to support their own positions and views; but the 
students are not allowed to express their occasional ideas in like manner. A professor can deliver a lecture in chapel and the student must sit and listen; but when the student delivers his oration the professor can go and play lawn tennis.

But at the same time the student and professor are very closely related. The student has the greatest extension and the professor has the greatest intention. The student causes the man to become a professor, the professor causes the boy to become a student.

G. V. JoHnson.

A new chemical compound has lately been discovered. It has been named "Egzactly," a name derived from the Anglo-Saxon root "just-so," meaning correct. When it is mixed with the compound "sufficient," it has a specitic gravity of 10 . In this state, it produces a pleasing, exhilarating sensation in the student.

\section{THE PSALM OF THE THIRD-YEARS.}

The president is my guide, I shall not fail. He leadeth me in the paths of wisdom for his salary's sake. He maketh me to find a good boarding place. He giveth me ten cents on the pay-roll. He telleth my parents I am doing well. Yea, though I incur the displeasure of a professor, I shall not fear. Thy lectures and thy precepts they comfort me. Thou acquittest me in the presence of the faculty. Thou teachest me to walk uprightly in the paths of rectitude, lest I fail to get a girl for the social. Thou makest my grades not to suffer. Surely prosperity and board-bills shall follow me all the days of my life, and maybe I shall be a U. G. next June. 


\section{THE CITY-BRED JUNIOR.}

How dear to my heart are the antics of Shylock,

When thoughts of the "bull-pen" present them to view;

His gesticulations, his lectures on Hubback,

With all the contortions that there would ensue.

His facts and suggestions, both ancient and modern,

I chewed up and swallowed until I was full.

When my fancy reverts to the boys in the "bull-pen"

Then I think of the junior, who curries the bull.

The thoroughbred junior, the dignified junior,

The city-bred junior, who curries the bull.

That extract of farming I hail as a treasure,

More valuable even than pitching manure;

And every P. M.ist regards it a pleasure

Which the poet delights in, but he can't endure.

And when he approaches that genus, Bostorus,

The grandson of Hubback, the gentleman bull,

He chants to himself that contemptible chorus,

And regrets he's the junior, who curries the bull,

The thoroughbred junior, the dignified junior,

The city-bred junior, who curries the bull.

How often I wondered why 'twas that our Shylock

Did not cross the ocean while I was a prep,

And take as a relic his Polled Angus bullock,

To experiment with and establish a "rep."

But soon he'll leave all to his worthy successor,

And soon for Australia his freight he will pull;

Then we'll all shed a tear for our new Ag. professor,

And sigh for the junior, who'll curry the bull.

The thoroughbred junior, the dignified junior,

The city-bred junior, who'll curry the bull.

G. J. V.Z. 


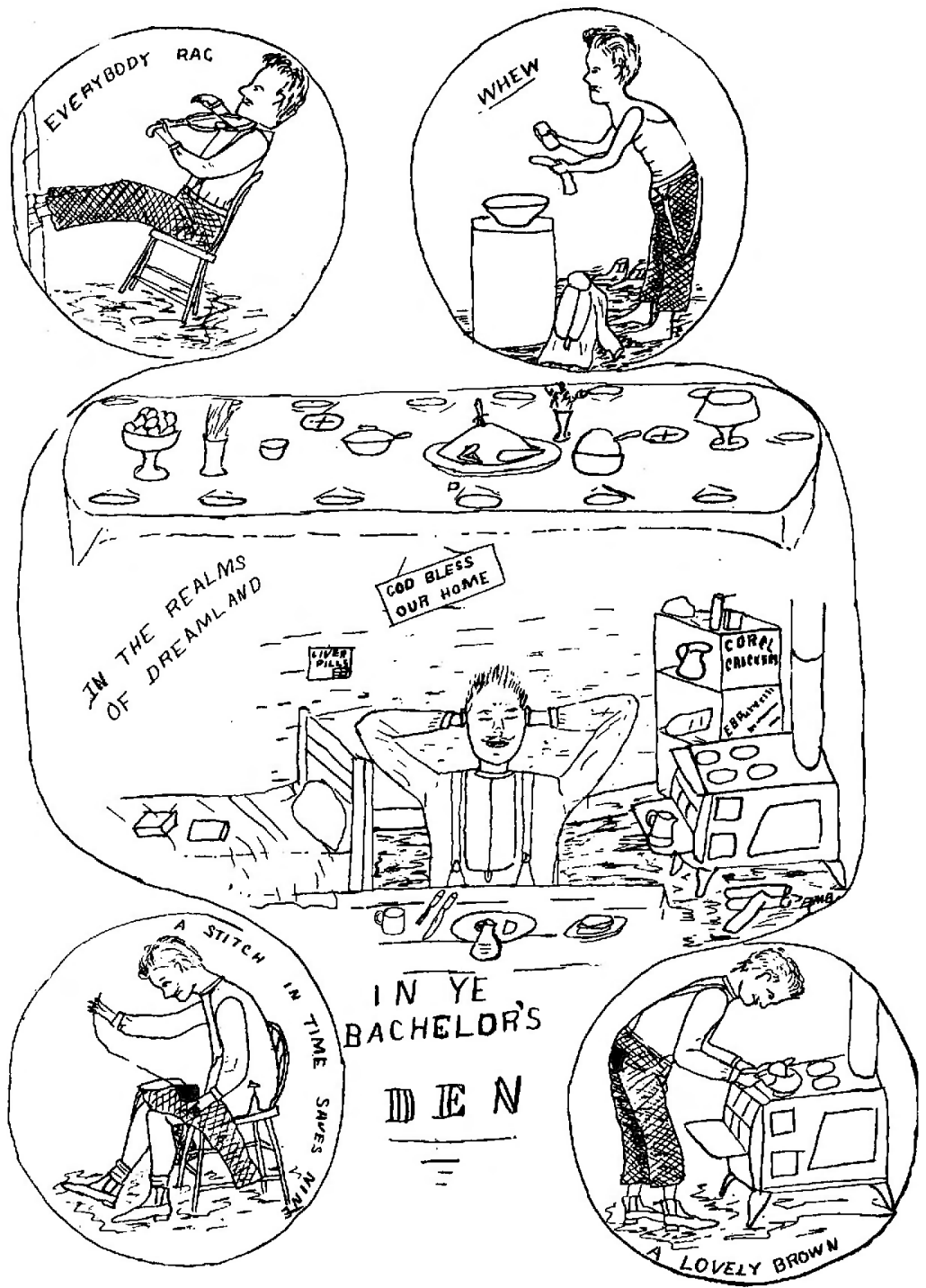




\section{BACHING.}

Baching is the art of economically administering to one's soul and body the luxuries of life for some definite end, generally the end of the bachelor. Baching is an art and not a science, and it is closely related to the art of agriculture. There is this striking difference, however: agriculture, or farming, is the art of tilling the soil, while baching is the art of letting Nature take her course without tilling. Farming exhausts, while baching accumulates soil. Though, as I have said, it is purely an art; many of the sciences may be pursued with interest in the genial home of the bachelor. Could we find an entomologist constitutionally strong enough to enter the bachelor's den, he might there find material enough in his line to busy him in its classification all the rest of his life. The horticulturist would be amazed to see whole crops of potatoes grow, bloom and bear all in a fortnight under the bed. The botanist could find five hundred varieties of mould and micro-organisms in his bread and hash. The chemist would conclude that the dough of which his batter cakes are made is a most wonderful compound. The physiologist would swear that a "patent roller process" grist mill could not digest half the food which he relishes every day for his dinner. If the specialist could see him during many phases of his existence he would surely pronounce him the missing link.

Every operation in baching is absolutely practical, and has mighty little theory involved anywhere. When a fellow sits down to breakfast, shuts his eyes, and converses with himself a few minutes, and then opens them, only to see before him bread, toothpicks and coffee; and when he knows that he wouldn't see any more if be looked a month, this is what I call practical life. If for dinner he just sees tooth-picks, bread and coffee, and for supper, coffee, tooth-picks and bread, then he is a wise bachelor, and practices a system of mixed husbandry. For when a man is compelled to do his own work and also his wife's, or if he hasn't got a wife, the work somebody else's wife ought to do, I would call this mixed husbandry, and badly mixed, too.

$$
\text { F. A. Campbelil. }
$$




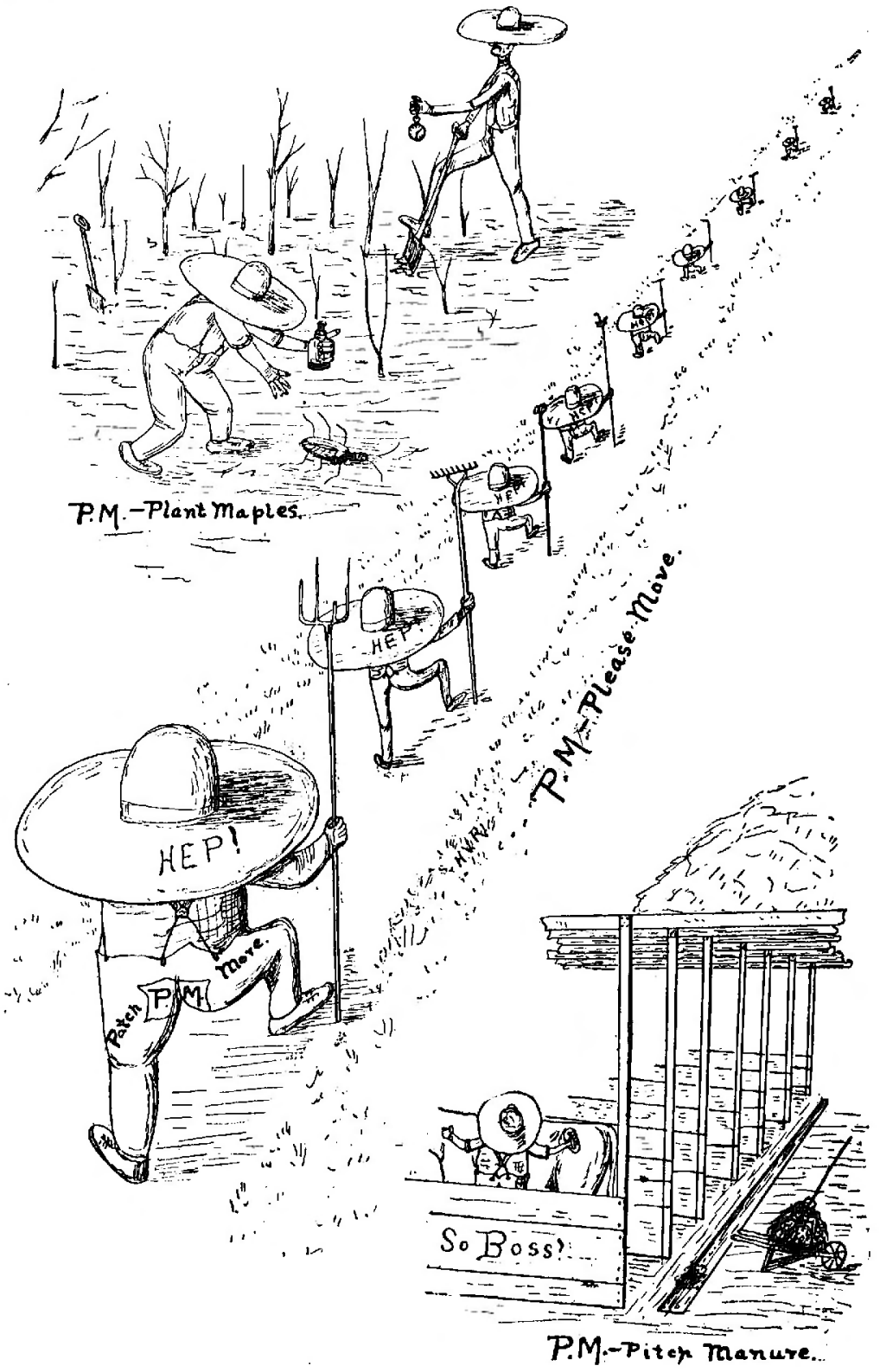




\section{P. M. DAYS.}

Can it be that $P$. M. days

Are to me forever past?

Prof. Georgeson never more I'll see,

The hoe no more I'll grasp.

My days at the K. S. A. C.

Are drawing near a close,

And I'm to drift on life's broad sea,

Where "Hort." one never knows.

And then I'll think of days long past,

The happy days of yore;

When once I struggled with P. M.,

A haughty sophomore.

It first was down to the barnyard,

The place where Cottrell reigned,

My soft and dainty little hands

With mud and such were stained.

That day I worked in my good clothes,

My old ones I'd not brought,

And all the dirt about the barn

On my good clothes was caught.

The bosom of my nice white shirt

Showed that it had been soiled;

I marred the poilish on my shoes;

My collar, it was spoiled.

Gloomy, sorrowful day of yore, Day of the not far past,

To me you ne'er will be forgotMy first, but not my last.

Oh! with what joy of heart I hear

The ringing of the bell-

A joy that only in the hearts

Of P. M. boys doth dwell.

But now my P. M. days are gone,

I feel no more the same;

I long to toil as once I did,

I long for wealth and fame;

But carpentry is my sad lot,

P. M. no more I'll see;

But while I'm working at my trade,

P. M., my heart's with thee.

L. S. StrRickLER. 


\section{TWO KINDS OF COURTIN'.}

There was a man in our school,

Whose name you know quite well, sir,

Whose crooked ways and sins so dark

It pains me much to tell, sir.

One bright spring morn, he and a chum

Went out to take a ride, sir;

A lady fair, with tender care,

Each youth placed by his side, sir.

With jest and song they sped along

o'er hill and vale and plain, sir,

No pause they made in sun or shade,

But drove with might and main, sir.

The hours flew by, the day declined, But yet they did not stop, sir;

The jaded horses, faint and dry, Were ready, now, to drop, sir.

Still on they went from place to place, Till the country they'd gone o'er, sir, And each fair maid, within her heart,

Had dubbed her beau a bore, sir.

At last they reached Manhattan town,

They came in on the fly, sir.

But when the stable door was gained, That team lay down to die, sir.

Then rose the owner in his wrath

And hied him to the squire, sir.

He vowed that they should feel the force

Of legal vengeance dire, sir.

The officer now brought these youths

To answer for their sport, sir;

But oh, it was a " bitter pill"

To 'tend this kind of court, sir.

Their "Pas" were next called on to come

And pay for that long ride, sir;

They vowed that when those boys got home

They'd tan their precious hides, sir. 


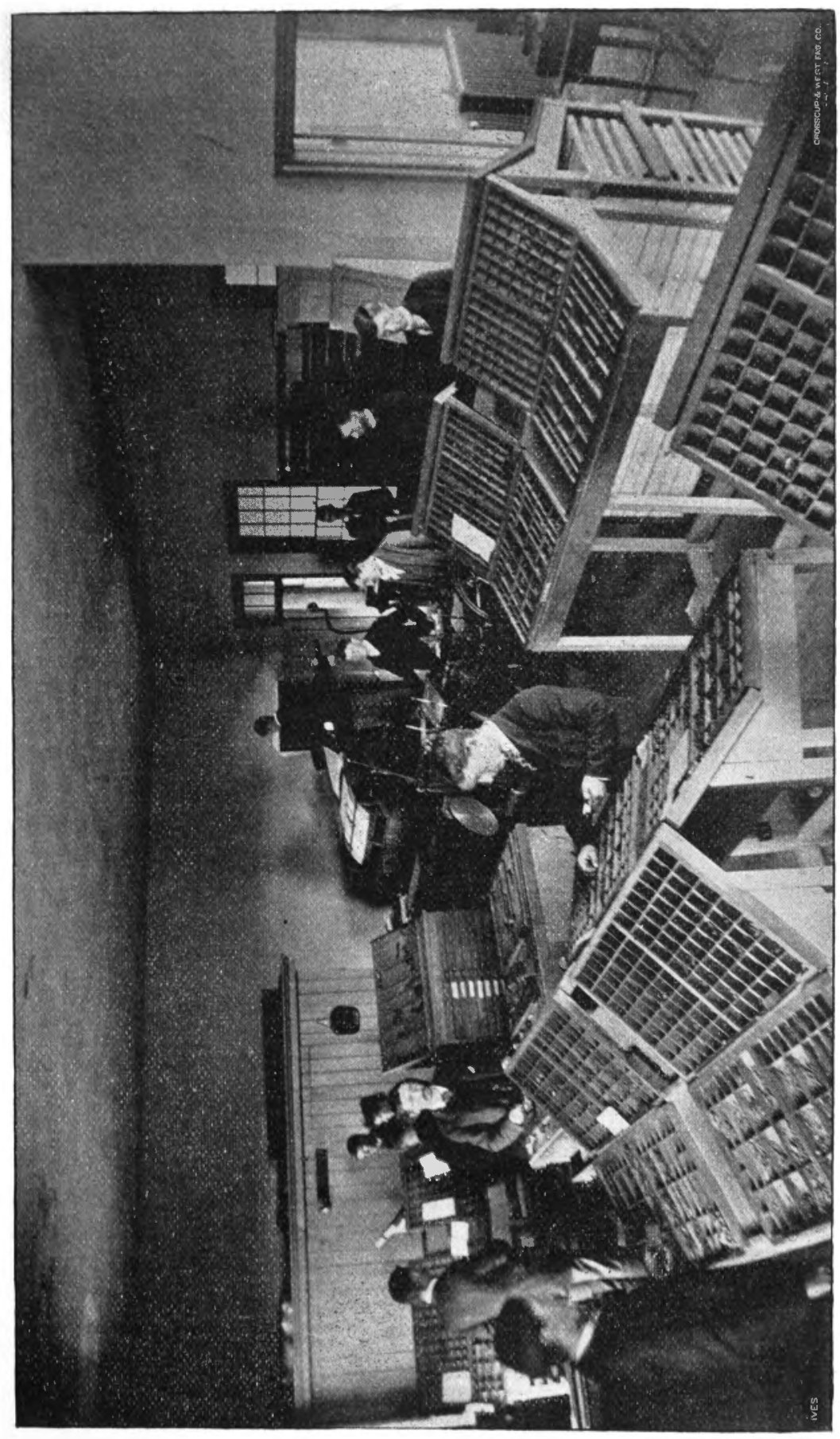

最 
To school again they came at last,

Of much hard cash bereft, sir,

And when they called to see those girls,

They found that they were left, sir.

The girls, you see, wished not again

To get in such a plight, sir,

So one of them she bounced her beau,

And now drives out with-Brown, sir.

The other claimed her witness fees,

They came to seventy cents, sir,

Her beau said he'd not have a girl,

Who had so little sense, sir.

The moral to this story's plain,

And he who runs may read, sir:

Now ye who take your girls to drive

These youths' sad fate should heed, sir. 


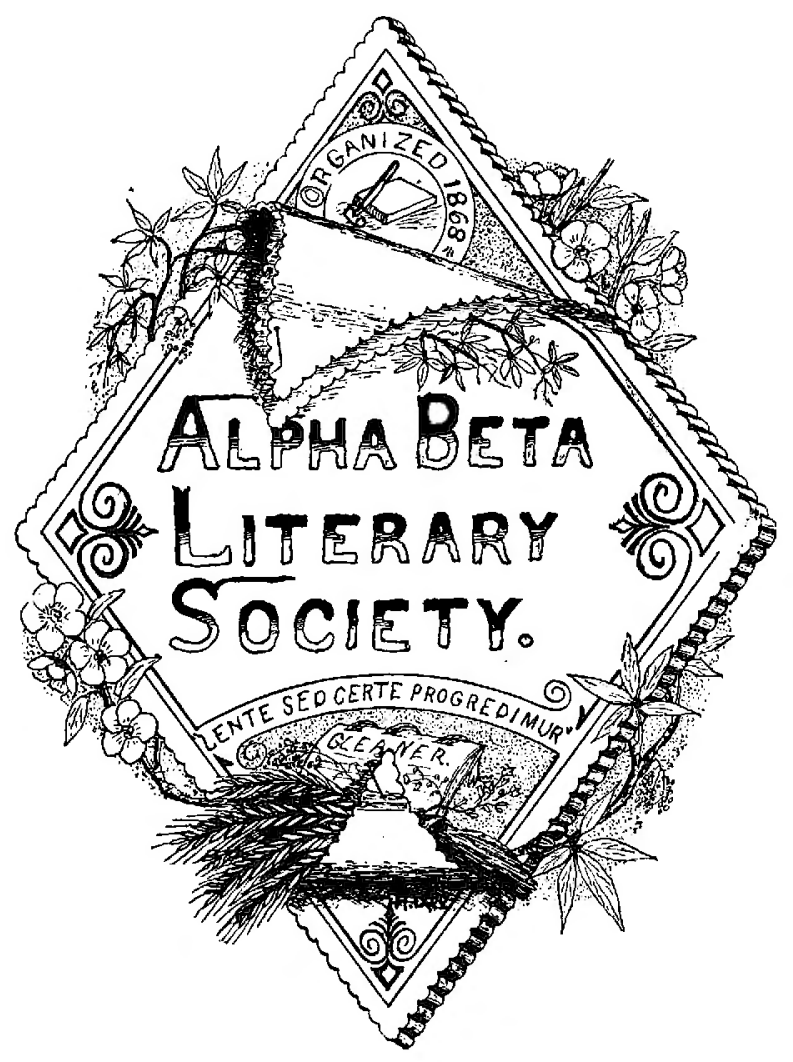




\section{HIS'TORY.}

Previous to October, 1868, The Bluemont Literary Society was the only institution of the kind existing at this College. Division arose among the members, and on the night of October 10, 1868, the society was dissolved by vote. Two new societies were organized within the following week, by the factions. One of these was finally called the Webster and the other the Alpha Beta Literary Society. The Alpha Betas were C. K. Humphrey, A. H. Tanford, L. B. Tolin, T. E. Campbell, Arthur Stewart, H. F. Miller, C. W. Allen, H. F. Huffsmith, C. Kimball, M. Bilander, C. W. Points and G. W. Hannum. They were soon joined by others, and from that time to the present the society has had a goodly degree of success; not that it has bad no dark days, for on more than one occasion in the early years of its existence when the students of the College were few in numbers it failed to continue its meetings till the end of the year for lack of attendance. But the members who felt the society to be a part of their college life were strengthened in their devotion by these adversities. The new year always found the society in better working condition, the society ties stronger, and all benefiting themselves by making the society a good one. In latter years the membership has been too large rather than otherwise.

In December, 1870 , the society obtained a charter for ten years, and thus became the first chartered society of the College. After the expiration of this charter, a new one was obtained for a period of ninety-nine years.

The original society was composed wholly of gentlemen, but various attempts were made in the early days to admit ladies to membership. With this in view, the time of meeting was changed, December, 1874, from Saturday evening to Friday afternoon. This action met with determined opposition, and was under consideration for several sessions before the necessary three-fourths vote could be obtained. Finally, with every member of the society present, twenty-four in all, the vote was taken, and eighteen voting aye the amendment was declared adopted. Two weeks thereafter the following five ladies joined: Mrs. W. K. Kedzie, A. B., nee Gale; Mrs. R. Kedzie, M. Sc., nee Sawyer; Miss Lottio Burroughs; 
Miss Marian Failyer and Mrs. Wm. Ulrich, nee Failyer. Other ladies soon followed the example of joining a literary society.

At this time the Websters were the only competitors, and some of these felt called upon to organize a new society admitting ladies. Many leading Websters joined this new organization, called the Diagnothian Society, but after a little more than a year it was discontinued.

The Alpha Beta paper, called The Literary Ensign, first appeared in December, 1868. It was not a regular feature, but was presented only on the occasion of public exercises. The latter consisted of public debates, plays and joint debates. In 1875, two years from the last appearance of the Ensign, the Gleaner, the present society paper, was started. It appeared each alternate meeting until September, 1882, when it was changed to a weekly paper. At present it is edited by one of the four divisions of the society, who elect their chief at the beginning of each term, and its preparation is the most profitable of society work. In 1884 selections were made from these papers and published in a book entitled the "Gleaner Gleaned," which contained work of high literary merit.

In 1877 a series of entertainments were given down town for the purpose of securing a library fund. In these plays, staid, sober, and matter-of-fact students acted the part of tragedians, comedians, millionaires, fops and love-lorn maidens, to their own satisfaction at least. From the proceeds of these entertainments, increased by liberal donations from members of the faculty, and appropriations from the society treasury, a valuable collection of books was secured. As the growth of the college library rendered the society library unnecessary, these books were sold in 1884, and the proceeds used to assist the Websters in purchasing furniture for the new society hall. It was then found necessary to institute dues, which were at first fixed at ten cents per term, but afterwards raised to twenty-five.

On the whole, the work of this society has been very harmonious, and fines, suspensions and expulsions, things so common in most college societies, have been but infrequently resorted to, there being little or no occasion for such work.

By consent of the faculty, the society appeared with its first 
Annual Exhilbition, in 1882. It has appeared each year since, and these entertainments have proved one of the most enjoyable features of the society.

Meetings are now held in the neatly furnished hall set apart for college societies, in the south wing of the main building, with a high average attendance of its fifty-six active members. It continues to play its part in the training obtained in this institution.

\section{LIST OF PRESIDING OFFICERS.}

1868-69-L. B. Tolan, C. N. Points, J. C. Soupene, H. F. Miller. 1869-70-J. C. Soupene, D. R. Sandchiff, C. O. Benton, A. F. Stewart. 1870-71-A. F. Stewart, W. D. Gilbert, J. H. Balser, W. B. Davis. 1871-72-C. D. Walker, Edgar Rose. 1874-75-G. H. Failyer, G. A. Gale, S. C. Scheumaker. 1875-76-Nellie Sawyer Kedzie, A. A. Stewart, G. A. Gale. 1876-77-Wm. Ulrich, W. P. Burnham, J. S. Griffing. 1877-78-W. H. Sikes, A. E. Wilson, A. A. Stewart, G. L. Platt. 1878-79-A. T. Blain, C. J. Reed, W. H. Sikes, G. H. Perry, jr. 1879-80 - G. E. Rose, G. H. Platt, E. P. Coleman, M. E. Sickels, W. N. Rose. 1880-81-W. J. Lightfoot, W. J. Jeffrey, F. M. Jeffrey. 1881-82-Geo. Hopper, J. T. Willard, I. D. Gardiner. 1882-83-F. W. Dunn, Jacob Lund, M. M. Lewis. 1883-84-Henry M. Cottrell, Geo. C. Peck, Effie E. Woods Shurtel. 1884-85-F. J. Rogers, A. Dike, F. Henrietta Willard Calvin. 1885-86-W. E. Whaley, A. M. Green, Ida H. Quinby Gardiner. 1886-87-D. W. Working, Nellie Cottrell Stiles, C. A. Murphy. 1887-88-C. G. Clarke, Bertha M. Bacheller, O. L. Utter. 1888-89-Hattie Gale Sanders, Emma A. Allen, H. W. Stone. 1889-90-Emma Secrest, Marie B. Senn, E. P. Smith. 1890-91-Nelie McDonald, E. C. Thayer, W. W. Hutto.

\section{ROLL OF MEMBERS.}

91.

Christine M. Corlett, Mary E. Cottrell, Delpha M. Hoop,

G. A. Browning, Grace M. Clark, G. L. Clothier, Elizubeth Edwards,
W. W. Hutto, Nellie E. McDonald, Lillian A. St. John,

'92.

J. N. Harner, R. A. Mcllvain, Kate Oldham, Birdie E. Secrest,
E. C. Thayer, Effie J. Zimmerman.

May Secrest, J. E. Thackrey, Winifred Westgate. 
'93.

Maggie Campbell, Martha D. Campbell, R. A. Clark, Martha A. Cottrell, Louise Daly,

A. L. Brooks, Grace Dille, G. W. Fryhofer, Nora Fryhofer, David Gamble, Carrie Hall, Hugo Halstead, Martha Hoyt,
E. A. Gardiner, Maude Gardiner. E. W. Gilkerson, Pamelia Hoyt, Fred Hulse,

'94.

s. O. Huffman, W. O. Lyon, Onie Hulett, L. McGrath, R. B. Meade, W. C. Meade, A. B. Newell, W. H. Phipps,
J. F. Odle, Maude H. Parker, J. E. Taylor, Joseph Thoburn, C. H. Thompson.

Joseph Salverson, Erna Schroll, Emma Skow, Fairy Strong, Fanny Thackrey, Mame 1. Thompson.

D. Timbers,

THE HERO OF EVERY DAY LIFE.

[Oration delivered at the U. G. Exhibition, 1890, by Nellie McDonald.]

The human actions of the present seem never to have been fully appreciated. 'Tis the fact that a thing is past that lends to it enchantment. How often do we hear the sigh for days gone by! How much does time magnify and brighten a good deed! As seen in the distant past, the age of chivalry seems to have been the most brilliant period of the world's history. But much of this pretty illusion is destroyed when we inquire into the condition of society at that time. We find that there never was a period when human society was more degraded, than during the feudal ages. Out of this dark mass of ignorance and superstition, there arose a spirit of gallantry toward the weak and defenseless, and especially toward woman. Is it not to this half imaginary superiority that we owe our fanciful and romantic idea of the knights of chivalry? Like Don Quixote, we see in imagination the gallant knight in glittering armor, mounted on his noble steed. He is ever on the alert, appearing, as if by magic, at the most critical moments to frustrate the designs of some villainous conspiracy. Such is the picture we draw of the knights of chivalry. And truly, there is much in that gallantry to which feudalism gave rise, that at once excites our admiration and enthusiasm. But, tear from chivalry the glossy drapery with which the poets have veiled it, and you will behold it in all its deformities. 
There is, however, no stage of existence through which society has passed, that has not had some advantages. These heroes with their gallantry and consideration for woman, merit our everlasting esteem and gratitude; for it was during the feudal ages that woman received an influence she never before possessed.

But as the artificial is to the real, the false to the true, so stands the knights of chivalry to our own hero of every day life.

There is a class of men, whom it is perhaps not proper to call heroes of every day life, yet who deserve our especial attention. I refer to the heroes of science. Those self-sacrificing spirits devote their whole lives and energies to the acquisition of that knowledge for which the world has ever stood so much in need. To them we are under lasting obligations. To them we owe the marvelous results of our own civilization. Words cannot express the esteem and gratitude they deserve.

But where shall we find our hero of every day life? Do we find his name in the pages of history? No! Still less does the world resound with his praises. If we would find our ideal we must search the humble abode of those unpretentious men whose highest ambition is the practice of truth and virtue. What care they for glory? Such was the motive that led to the protest against the English Church. From the very depths of our hearts we can say, all honor to our Pilgrim fathers, to that vast host of working men who subdued the wilderness and the wild beast, and to whom we owe the marvelous results of our own civilization. But shall we give due praise to dead heroes and turn a deaf ear to the humble laboring heroes of our own time? Are not many of them doing as much to make the rough places smooth, both for the present and future generation as did our Pilgrim fathers? Then let us honor them while they live, let us encourage them while we may. Let us lend a helping hand and lighten their burdens, so that they too may have time for mental improvement. And now as we speak the hollow reverberating praises of past ages let us raise our voices in commendation of the laborers of to-day.

Who is more worthy of praise than those self-denying fathers and mothers who toil early and late that their children may have greater advantages than they had themselves? There stands the mother at the wash tub in her homely garb, toiling beyond her 
strength that her loved ones may have those privileges she so longed for, but which were denied her. And who does not know of a father who warks from morn till night, through summer suns and winter storms, denying himself everything that his sons and daughters may be well educated? Do not sneer at their want of culture, or their slavish occupation, for if they had no conception of a higher life they would not labor thus for such a cause.

To my mind one of the most heroic actions ever witnessed is the youth battling against an inherited tendency toward intemperance. How unjustly he is blamed for giving way to his appetite! $\mathrm{He}$ only knows how great and how almost hopeless is the struggle.

No, my friends, the world has not yet recognized its truest, bravest and noblest heroes; those who are laboring for the advancement of mankind, for the common brotherhood of man. They are fighting ignorance in all its hydra-headed forms. They are banishing physical suffering and bloodshed, whereas the former hero's glory was measured by the extent of his destroying powers. If we would see that which is worthy of the name of heroism, we must look for it among those whose ambitions have never been influenced by selfish motives-among those who have striven to be good, rather than to be great-to bless others rather than aggrandize themselves. Their names have found no place in the world's history; the beauty of their daily lives has passed all unseen, save by the angels; yet it has blessed the world. In this high heroism all can take part. It lives in the heart of the nation, and the body of this great republic bears the noblest blood of nearly three centuries of American heroes. The field is as broad as the world, its aim as high as the heavens.

\section{HARMONY OF TWO NATURES.}

[An oration delivered at the Alpha Beta Exhibition in 1891, by Delpha Hor.p.]

Have you ever watched the growth of the rosebud to the flower? Have you seen the bit of green swell and grow until it burst the bonds that hid its beauty and gave you a glimpse of the treasure within those green walls? And then, in pleased wonder, did you see the flower unfolding its delicate petals to the sunlight, breathing its fragrance on the delighted air, opening more and more, un- 
til a beautiful, perfect rose had taken the place of the simple bud? Have you seen this-yes, and loved it, too, for you could not help loving if you saw?

You who have seen this, did you ever observe the growth of another flower-the flower of human life, of human nature? Yes, you have watched the child, first struggling to comprehend the relation of selfishness to its acts, grasping the ideas of right and wrong, broadening all its thought, growing, expanding ever. You have seen the nobler nature within it, unfolding, pushing its way through temptations, rising again, ever going forward, sometimes defeated, always triumphant. And you that are old have been permitted to rejoice in the full, glorious life that has been moulded by the once weak child.

No higher joy can there be than this. Over and over again, I doubt not you have thought, "an honest man's the noblest work of God." But again you have seen the flower wither before it had ceased to be a bud. You have been disappointed many a time to find, when the rose was burst, that a worm was at the heart. So it is, too, with many a human life. It never realizes the great result for which it was designed. The "worm in the bud" has eaten away too much of the nobler life.

There is an analogy between these two flowers. In all relations can Nature and human nature be said to resemble each other. The greatest difference arises from the fact that human nature is so much the higher, and yet, the nearer to it we place Nature, the more true we become to human nature.

Everywhere the influence of Nature upon man has been for good. She teaches him of higher things. The least, the lowliest thing in nature has its own lesson to teach if we will oniy listen, for as Longfellow tells us,

"Nothing useless is, or low, Each thing in its place is best;

And what seems but idle show

Strengthens and supports the rest."

"All are but parts of one stupendous whole.

Whose body Nature is, and God the soul;"

and it but follows that a closer communion with Nature gives a better and holier knowledge of her God. The sympathy between 
man and Nature is instinctive. Those who understand and appreciate Nature least, are not insensible to her soothing influence.

What a relief it sometimes is to get away from the hurry and worry the world is often in, and forget it all in the contemplation of the beauties of Nature! We know that we have in her a friend that never changes. She is always ready with some manifestation of her sympathy when our human friends puzzle us too much, or are unusually trying. In loving Nature we do not take away any of the love for man, but by our love for her, are enabled to give a nobler, more unselfish and understanding love to man. One of Nature's highest missions is to help us to understand one another. We must not judge people, or misjudge them, rather, by that which appears on the surface. As has often been said, "The most precious jewel may be found in the roughest casket." Not only that, but with many people it requires a long acquaintance to reach their true selves, and we are liable to hastily conclude that they are unsympathetic, or at least unresponsive. If we could only look into the hearts of those around us, more true and enduring friendships would be formed; and hosts of people, now indifferent to each other, would be friends.

Nature shows to us only what we are able to understand. For each one of us, she is just what we make her. We may blind our sight and look upon a beautiful landscape unmoved. We may see a tree clothe itself in its green mantle for spring and feel no joy in its beauty. We may listen to the singing of the birds with no feeling of sympathy or love. The love of Nature is, in a great degree, the result of education. It grows with our growth. To the child, a leaf is simply pretty, but when the mind of the child has been developed the leaf is no longer merely beautiful, but it tells him of a law, wonderful and harmonious, that has given it being.

Very many people live all their lives without giving one real earnest thought to the nature that is around them. For them there is no delight in a moonlight night, no beauty in the form of the snowflake, no Supreme Being speaking in the voice of the waterfall. Truly, of them it may be said, "Eyes bave they, but they see not; ears, but they hear not." Often they say they have no time for such things. But of such things is the purest pleasure in nature made up. It is a part of our being that we need such things 
to make us happy. God has given us all these beautiful surroundings for some purpose. The enjoyment of them is not alone to the rich, but to the poorest laborer as well. What less can we do than to appreciate and be grateful for them?

The power to love Nature is innate, but whether we use that power depends almost wholly upon ourselves. We may become so taken up with our daily cares, so intent upon business affairs, that we really do have no time to see or feel any of the good and beautiful things in nature. We bridle our imagination, afraid that it may make for us a pearl out of a drop of dew; afraid that as we watch the sunset, instead of the gold and crimson clouds, set in a blue sky, we may see the celestial glory streaming through the gates of heaven. There is no greater mistake than this, for, by the aicl of the imagination, we see not only what is, but what may be; all the possibilities hidden in the simplest thing. We always think of heaven as having all things lovely and harmonious. If we wish to enjoy them fully there, we must love and understand, as far as we are able, the things we have with us here. This life is but the preparation for the life to come, and it is our duty to bring into it and make a part of ourselves all that is good or productive of good.

\section{MAKE THYSELF A NAME.}

The desire to distinguish ourselves, to rise above the common herd, to carve out a name and fame that shall exist long after we have returned to the dust, seems to be an almost universal one, and various have been the means resorted to to gratify it. History tells of one whose splendid victories for a time dazzled the world; the Persians, the Egyptians, the Hindoos, alike went down before him. The Scythian fled to the desert at his approach, the Arabs acknowledged his supremacy; among all the nations there was found none who could successfully oppose him. Yet, great as Alexander was, he fell a victim to his own unconquered passions. Verily, he made himself a name, but it was by slaughtering countless thousands, by making himself a merciless butcher.

A ship is sailing from an English port. Leaning against the taffrail and gazing at the receding land, fading for aught he knew forever from his sight, is a young man who is destined to achieve 
grander conquest than any ever imagined by Alexander. In the prime of life, voluntarily exiling himself from home, friends and country, to carry the gospel to the Hindoos.

To-day on the banks of the Ganges, thousands of dusky Christians speak the name of Carey with reverence, with love almost approaching adoration. Alexander's empire lasted only while he lived; but the empire founded in India by William Carey will last as long as the earth stands.

The deeds of Carey are not written on blood-stained pages, but stamped upon the hearts of those upon whom he conferred the twin blessings of the gospel and civilization. Who remembers, to-day, the generals that distinguished themselves in the Crimean war? Nobody! The names of Ragland, Scarlett, Cardigan and St. Amand are recorded in history, 'tis true, but the deeds of their bearers are forgotten; but the name of that heroine, devoted hospital nurse who cared for their sick and wounded soldiers, Florence Nightingale is fresh in the memory of every man.

Who ever thinks, or even knows, that Cotton Mather was the author of three hundred and eighty-two works? Even the titles of many of them are forgotten. Poor, weary, discouraged and houséless Payne gave to the world one simple little song of only two verses, but it, coming from a homeless heart, touched a sympathetic chord of the heart of humanity, and the whole world has sung that song until the name and story of its author, John Howard Payne, are known wherever there are homes or homeless ones.

If you would make yourself a name, do something the world can appreciate; something that will be of benefit to others as well as yourself. Write your name on humane hearts as well as on the pages of history. Humanity is not ungrateful, but it is just. If you leave anything behind you worthy its remembrance, you will be remembered; if not, you will be forgotten, or worse, remain in history as a mere name and nothing more.

John W. Van Deventer.

A VIEW FROM ARAPAHOE.

One of the most interesting of Colorado's many peaks is that named the Arapahoe, situated near the central part of the State. Viewed from the foothills it appears in shape like a pyramid, but 
from the greater distance the angular outline is lost, and one sees only the sharp, white point rising high above surrounding hills.

It was a pleasant July morning during the summer of ' 83 , when, in company with two companions, I made the ascent of this peak. As I stood upon the summit and looked across the country lying below, what wonder that I almost became entranced? I thought it the grandest view of nature ever presented to me.

To the east, beyond the foothills, lay the barren plains of Colorado, dotted with hundreds of lakes, reflecting like mirrors the clear sunlight. From the northeast could be traced like a silvery thread the course of the Platte river. Looking south we could see vast herds of grazing cattle. Again and again we tried to discover a limit to the boundless expanse of country, but all in vain; each time the prairie faded into a blue haze. Close to the foothills nestled the town of Boulder, and far to the southeast could be seen faintly outlined the "Queen City of the West"-Denver. North and south the mountains streak away in one long continuous chain, broken here and there by such peaks as Long's, Gray's and Pike's. They seemed like giants keeping watch over their weaker fellows. The columns of blue smoke rising from cañons and mountain sides indicated the location of many a thriving mining camp. To the west lay that great natural basin, Middle Park, with its gentle rolling surface and groves of slender pines. Starting at the foot of the peak, a chain of minature lakes, with waters as green as emerald, extended far out into the park. In whatever direction we turned our eyes, something new presented itself. When we finally took our leave it was with a feeling akin to regret; regret because we could not see it all.

W. E. WiIALEY.

\section{SHADOWS OF LIFE.}

Everyone has, on a bright summer day, observed the shadows cast upon the earth by scattering clouds, first appearing over the hill tops, then gradually enveloping the observer, and then receding in the distance.

In the same way there are clouds of sorrow and disappointment that hide from us the sunshine of happiness. And we may often see them appearing from the distance, then overwhelming us for a time, then pass away and all becomes brightness and beauty. 
And after all, this is perhaps the better for us. As, after the passage of clouds, the sunshine becomes more delightful in contrast with the shadow, so the pleasures and prospects of life are far more enjoyable to us after having experienced its sorrows. Again, amid the eagerness and intentness with which we are engaged in some pursuit or pastime, we may become unconscious of cloud shadows about us, so, when clouds of adversity come over us and disappointment meets us on every hand, we may forget our own troubles by trying to comfort and encourage others who are weary of life's burdens.

In this way we may not only make ourselves happier but brighten the pathway of others.

In times of darkness and of gloom,

When all is care and strife,

Oh, how we cast a summer's bloom

By a pure and noble life.

if. A. Carlton.

\section{THE KATES.}

Did you ever think of the nam of Kate, And of some who chance to bear it,

How queer they look, and talk and act;

Some bad, and some with merit?

Now deli-Kate is a lovely Miss,

Both modest and refined;

But nobler fur, is edu-Kate:

She elevates the mind.

Base fabri-Kate none will believe,

Her talk is too absurd,

Twin sister of prevari-Kate,

Who never keeps her word.

Beware, I say, of tripli-Kate,

For if she takes you in

You'll have to call on extri-Kate

To get you out again;

And then, perhaps, on vindi-Kate

To make your actions clear;

Or else resort to suppli-Kate

To reach a listening ear. 
Miss intri-Kate's a puzzling girl;

You'll never find her out;

She is always leagued with compli-Kate.

To put your wits to rout.

Equivo-Kate ne'er speaks the truth,

For falsehood's her delight;

And expli-Kate, with all her skill,

Don't make the matter riglıt.

And dup i-Kate, I grieve to say,

Oft passes for another;

And tripli-Kate, so near alike,

You can't tell one from t'other.

But indi-Kate points out the fact

That corrus-Kate is shunning.

While invo-Kate, in pleading tones,

For each one asks a blessing.

But lest I hear from impre-Kate,

I'll call the roll no farther;

But simply say that convo-Kate

Will bring us all together.

JNo. W. VANDEVENTER.

WANTS OF A THIRD-YEAR.

"Man wants but little here below, Nor wants that little long."

The third-year says this is not so,

Instead, is very wrong.

"His wants are many, and if told Would muster many a score;

And were each wish a mine of gold

He still would wish for more."

What first he wants is a passing grade, And of "çheek" a steady gain;

For thus, you know, his right is laid In college to remain.

He wants a "stand in" with the profs., An ever winning way;

At all their jokes he loudly luughs, And then he 's sure to stay.

He wants, when in mechanic's room

And up before Prof. Hood,

A mirror to reflect his doom, 
0 , if he "only could!"

He wants to draw a map so grand, And fix it up in style;

That he with artists rare may stand And praised be, all the while.

When the Ag. supper 'gain is near With all its goodly things, He wants to be a second-year And share the joy it brings. He wants to have just lots of fun A-sliding down the hill;

But what a risk he has to run When called to "fill the bill."

He wants to go to every show, Likewise, to every dance, Without regard for future woe From zeros made by Lantz. He wants to be a perfect dude And make the natives stare; And would not falter to be rude, If that would get him there.

He wants a declamation fine, Not old and stale and dry; But one outside the usual line, The seniors to outvie.

He wants to be a U. G., sure, And on the stage appear. To talk in language most obscure, The while the seniors jeer.

He wants to organize his class And make it strong and true; But then he never can amass His forces so to do.

He wants the seal of power and place, The ensign of command, Charged by his classmates' unbought grace To rule the third-year band.

He wants a keen, observing eye,

A firm and level head;

Yet oft he rushes in to die

Where angels fear to tread. He wants to realize his dream 
Of future and of fame,

And has matured full many a scheme

T'o perpetuate his name.

His lust great want, absorbing all,

Is, when a fourth-year grim,

Intelligence not quite so small,

A mind not quite so slim,

Enough hard cash his board to pay,

And grades of which to brag;

A chance to speak commencement day, A partner for the " rag."

\section{AN ATOM OF OXYGEN.}

Late one evening as I sat thinking of molecules, of atoms, and of vibrations, and pondering the question of the persistence of motion, of creation, of existence, and of dissolution, I became strangely conscious that in a mysterious manner something was endeavoring to communicate with me. I listened; I looked; I felt; but all in vain. I said, "Who are you that thus assails my thoughts?" Then in some strange inexplicable supersensual manner I became conscious of the following communication:

"I am an atom of oxygen. In dimensions I am only reinarkable for my smallness. The traditional comparison to a mustard seed would, in my case, be but a mockery; for I am as many times smaller than a mustard seed as it is smaller than the pyramids of Egypt. My fellows more than make up for my deficiency in size. Drops of water in the ocean and grains of sand on the sea shore would be a poor comparison, for every grain of sand and every drop of water contain thousands of millions of my fellows. As to my properties, I can only say that I am indivisible and unalterable. When was I born? I was not born. Sometimes I almost persuade myself that I was not created, but that there never was a time when I was not. When all was chaos - long before when God said, "Let there be light,' I existed. After order had been established I and my fellows were the chief agents in that wonderful upbuilding and destruction that has not yet ceased. We floated in the air; bound to atoms of hydrogen we formed the waters; and united to other atoms we formed half of the solid globe itself. But the world was not destined to continue to be a scene of desolation. With my aid 
plants came into existence and I found myself bound to an atom of carbon hurrying to their leaves, there to be shaken asunder by the rays of the sun; next to become the breath of life to some animal; later on, being bound to atoms of hydrogen forming water, I was again found to be indispensable to all life. And when proud man came to the stage of existence, his every action, his every thought, his very existence was hopelessly dependent on atoms like myself.

"My personal adventures have been numberless. At one time it would be my fate to form part of a body of a Napoleon; the next change might find me a part of the rust on his sword, aiding to propel his missles of death; in the tear drops trembling on the lashes of a mother made childless by his success; flowing from the pen that signed his abdication, filling the sails of the vessel that took him to St. Helena, or forming part of his winding sheet.

"Continuous, never ending moticn has been my lot. I have been the agent of ceaseless changes. With the aid of me and with the aid of my fellows, civilization has been developed, nations have risen, great minds have flourished, wonderful discoveries have been made, glorious thoughts have been put forth, and yet changeless and unchangeable forever have I been. Unchangeable have I witnessed the formation of the world, the progress of life, and the rise of intelligence; and unchanged will I remain when the earth will be destroyed, the moon cease to shine, the sun grow dim, and the stars fade away. In all the manifold and wonderful changes that I have wrought, not once have I had any choice. I have always yielded with mathematical certainty to the strongest force that presented itself. And yet no force, however powerful, can ever crush or change me in the slightest particular.

"My future can be but a repetition of the past. I may aid in the development of intelligence and of civilization far transcending that of to-day; or I may be one of the agents of an equally great degradation. It matters nothing to me, for I will forever remain an atom of senseless matter. As oxygen, I am an agent of perpetual change; as an atom I am as changeless as God himself."

F. J. Rogers. 


\section{UNLY A DREAM.}

The day was fair; the air was mild The streams and birds made music rare;

Not e'en my thoughts I called my own, For I had banished every care.

My only wish, my one desire, As my bug-net lay by my side, Was that some rare but stupid bug Might into its interior glide.

I glanced toward the cheese-cloth sack, 'T was moving to and fro;

I gently raised the circled wire To see an awful show!

The bug I saw within that net Was larger than my hear;

Its eyes looked just like coals of fire, Or saucers colored red.

The antenna was clavate like,--

Looked like a base ball bat;

Its mandibles like grappling-hooks, Between them was my hat.

He dropped the hat and at me ran, Too scared was I to flee, But stood and screamed this, o'er and o'er, "Scat, you Searabida."

'T was sister who my hand did grasp, And smoothed my ruftled hair, And said, "I 'm sorry, Jennie, dear, You 've had such a nightmare.

Now go to sleep and rest till morn,Why, you 're all out of breath, Forget these horrid hexapods Or they "ll worry you to death."

\section{FRIENDSHIP.}

The world, so they say, is full of deceit, And frieudship a jewel we seldom can meet.

How strange does it seem, that, in searching around, This source of delight is so rare to be found.

When fortuve is smiling, whole crowds may appear, Their kindness to offer, with friendship sincere;

Yet chinge but the prospect and point out distress, No lon w ' ${ }^{\circ}$ to count you they eagerly press. 
Oh, friendship! thou balm and rich sweetness of life,

Kind parent of ease and composer of strife,

Without thee, alas! what are riches and power, But empty delusions-the joys of an hour?

How much to be prized and esteemed is a friend

On whom we may always with safety depend, Our joys when extended will always increase, Our grief forever is hushed into peace.

And whether the world condemn or approve, There is one that will cover our faults with His love; His friendship and care on this world He has given, And promises sweet of a bright home in heaven.

Lillie Bhidgiran.

\section{NOT TO THYSELF ALONE.}

Did it ever occur to you that all mankind is one great selfish individual, finding the consummation of all aspirations in self gratification? In him how little sympathy exists; how little brotherly love, that feeling which renders the interests of others as precious as our own! Would you see this selfishness exhibited? Then come with me into the streets of the city.

I believe that a dry goods box on the street corner is the best school. Here your books are human beings and your lessons human nature. The streets themselves and the very buildings seem to be bent on naught but their own interest. From the magnificent marble palace of commerce to the dilapidated little shoe shop, from one street's end to the other there dangles and flaps in the rustling wind, the index to what the stores contain. Shop windows are shining with glossy fabrics, or glittering with tinkling jewels, or overflowing with delicacies, tempting the eye with appeals to the stomach. The shop keepers are fighting for self; and how maliciously they eye each other as a customer passes on to a neighbor. But look to the sidewalk, where we come into man's sphere. I wonder if we then reach a higher plane. Looking at the crowd collectively, it seems to be a conglomerate mass of men, women and children; the molecular individuals of which are arranging themselves as incessantly as if obeying some mechanical law.

Analyze this mass of humanity and view the individuals, as the 
unorganized procession goes by you. It takes all kinds of men to make up this world of ours, and in no place is this more evident than here. Now passes portly independence, personified in the form of an elderly gentleman, whose manner and tread are that the sidewalk was laid for his especial benefit. Next the peacock element of humanity appears in the form of a millionaire's wife. She is self-consciousness adorned. Stand aside! Here comes a ten cent cigar with fire on one end and a fool on the other, who is beir to a delicate cane, that reposes meekly under its master's arm. His mind is dwelling on the contrast between the third and the fifth vowels. Here is the farmer intent on his business; there the schoolboy exultant in a holiday; here again, the stirring newsboy, the sloven bootblack, the professional man and the professional idler-men and women; white and black; rich and poor; innocent and guilty all are here, and all seek the good of self alone.

A crowd is a lonesome place. Gradually they gather into little groups; groups in greeting and in parting; groups of idle tongues at the corner, base wretches, commentors on passers by, enveloped in smoke, rivals in profanity. Again they disappear and are lost in silence.

The Pharisees and Levites are numerous, but the good Samaritans are few indeed. Here is an old colored woman, lame and feeble, limping along through the throng of men, subject to the jeers of idle loafers, spurned by men and shunned by women, yet she is braving the world alone - "urged on by peerless want." What a chance for mercy; what an opportunity for showing true manliness in lifting a burden from a human soul! Oh! Have you no heart, idle jester? Have you no tears for somebody's mother? 'Twill brighten your joys to lift her burden. 'Twill bring a ray of sunlight into two hearts. 'Twill be a spring of joy in a desert of grief. A sparkle from those eyes and a "God bless you" beaming from every wrinkle in that aged countenance will repay you richly for your kindness, and still you do not volunteer. What a crowd of selfish men :

Are you tired of human beings? Then turn again to the streets. The day is declining, and one by one vacancies are being made where first we saw the farmer's team standing. The continuous line is being broken and the intervals grow wider and wider, while the 
clatter and roar, with their reverberating echoes, "deaden and deafen the ear with their sound." What do you see in the distance, approaching the city? It is a hearse, a hungry living sepulchre, coming from the city of the dead. Its- reckless roll on the stone paved streets seems to be voicing the hollow, mocking tones of disregard for humanity that the whole brazen world is muttering.

But old Sol is sinking in the distant horizon. As he throws the last ray on the city, it is lit up with a golden lustre, and stands participating in the resplendent grandeur of the light of day. Each decked in his own most gorgeous robe cordially bids the other good night. The teams are gone; the town is still save the noise of men, my brothers, ever reaping something new; still hammering, still chiseling, till the clock on the tower announces the hour of six -then all is quiet.

Then does night throw the mantle of darkness on fleeting day, stars upon stars in the infinite realms of space conspire in vain to lift night's sable pinions. Darkness, the king of night, reigns. Self is gone, and the beautiful stars, "the forget-me-nots of the angels," spread their soft radiance over all. How happy they seem as they twinkle alike for all! Can we not, like the stars, forget ourselves and throw little rays of light into the hearts of those around us? Can we not be, instead of a burden maker, a burden bearer in this one great human family to which we belong? A kindly word and a friendly smile will live through eternity, and the God who is in all and who rules all in that mysterious realm, will place in your crown jewels that shall shine forever unto those whom you have left behind.

C. G. Clarke.

\section{A MODERN FABLE IN VERSE.}

Once upon a pleasant evening,

Not so very long ago,

Gay and festive college students

Went to see a meteor show.

They were anxious, so they started

For to get a first-class view

And to further their ambition,

Started out in squads of two.

The meteors were to be recorded,

But one fellow lost his book:

Long, but vainly, through his pockets, 
Did this hupless student look;

But his lady, woman fashion,

Said that since it came to this,

She'd agree to record meteors

Through the medium of a kiss.

Soon a heavenly body flitted;

'Twas a real meteor - this,

And its advent soon was followed

By that blissful record kiss.

Then a firefly titted past them,

While the heavens were dark and dim,

And she innocently asked him,

"Wasn't that another, Jim?"

Now the fireflies went on record

While the meteors came but rare;

But still faithful in recording

Were the sclentific pair.

But the fireflies seemed so drowsy,

And the meteors seemed so few.

That the records were not frequent

And they scarce knew what to do.

Soon the rumbling of a freight train

In the valley upward rose,

And the headlight of the engine

Like a fiery meteor glows,

As the should be meteor passed them-

The bright headlight of the train,

He to keep a perfect record

Promptly kissed his Susan Jane.

But the trains were slow in coming,

And the meteors slower still,

Yet the freight train, slow in starting,

Lingered by the city mill.

Now the switchman's lights are gleaming,

Flasling signals--that and this--

And each movement went on record

By a meteoric kiss.

They have wed; no more they linger

Watching midnight meteor showers.

()thers take their place in watching

Meteors, in the "wee sma" hours."

Science may predict a falsehood,

But still it is not to blame,

For in case of false predictions,

Kissing goes on just the same.

H. W. JoNES. 


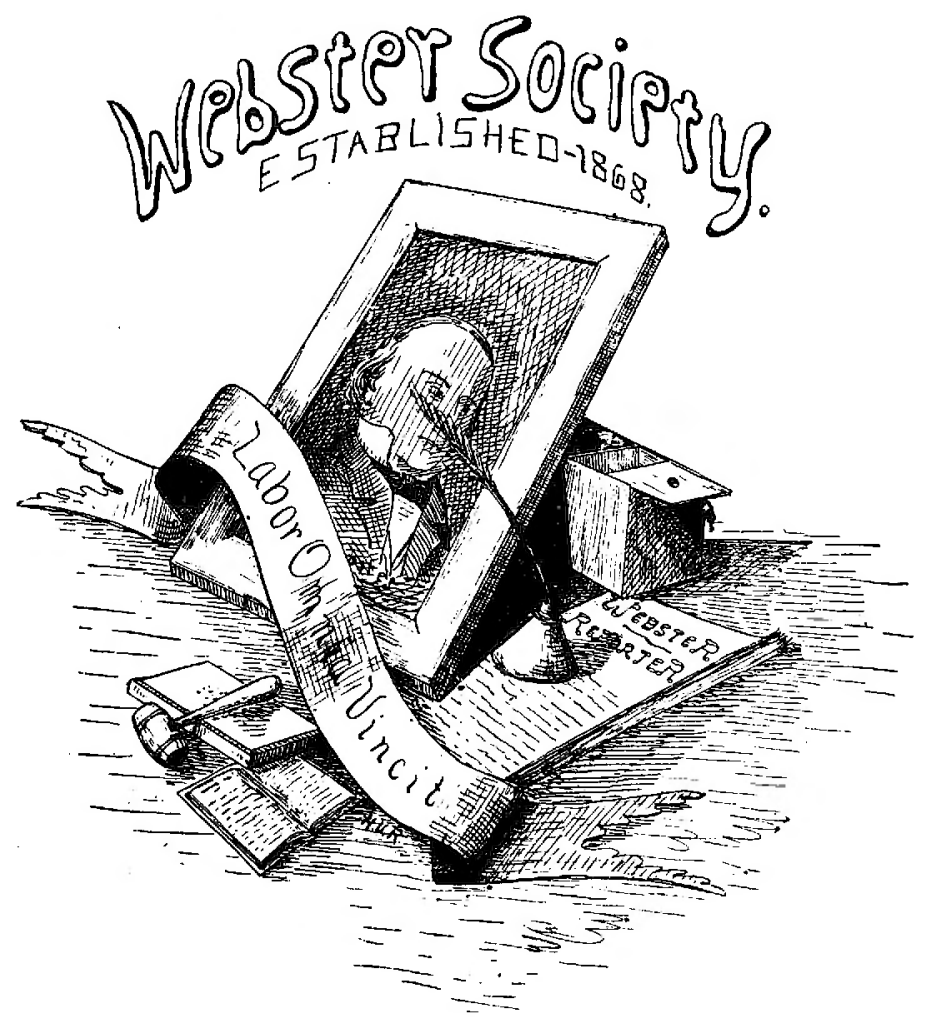




\section{HISTORY.}

The inmediate causes of the dissolution of the "Bluemont Literary Society" are somewhat shrouded in mystery. Suffice it to say, however, that the result of the turmoil which accompanied and succeeded its demise was the organization of the present Webster Society, under the caption of the "Websterian Jiterary Debating Society," as proposed by Mr. Williston. The name was soon changed to "The Webster Literary Society," as it now stands, and a constitution was immediately adopted and placed in the hands of the printer for publication.

The birth and subsequent development dates from the 12th of October, 1868. Among those whose names appear as charter members may be mentioned: J. F. Johnson (since dead), J. P. Shannon, C. O. Whedon, C. H. Young, J. D. Houston, jr., A. F. White and $\mathrm{S}$. Wendell Williston.

For nearly three years the society was on a very precarious footing, owing as much as anything, perhaps, to the fact that the society spent the most of its time in electing officers and the remainder in challenging the Alpha Betas to join debates, instead of attending to their legitimate duties. In January, 1871, Mr. C. O. Whedon was appointed to secure a charter for the society, which was accordingly done. The name, object, etc., were placed on file in the State Auditor's office.

At the suggestion of Prof. Hougham, who proposed to give five dollars, provided the society should give an equal amount, a library was started in February, 1872. By various other contributions and donations of books and papers, the library grew in usefulness to the society until the fall term of 1885 , when it numbered 250 volumes. At this time, deeming it unnecessary for the society to own a library when the college library was at the disposal of the members, and being in special need of funds to defray the expenses of furnishing the new society hall, it was sold at auction.

Saturday, March 30,1878 , the first monthly edition of the Webster Reporter appeared, with A. N. Godfrey as its editor. A few months later the semi-monthly Reporter appeared, and has 
been continued to date. The interest taken in the paper is manifested in the attention given it, and in the regularity of its issue. The drill furnished by it has been a source of both pleasure and profit to all taking part.

The large assembly which met to witness the work of the society at its first annual exhibition, March 29, 1883, showed how much the public had become interested in its work, and this, in turn, stimulated its members to more zealous activity. Since that time they have given to the public, from year to year, the rich fruits of their untiring efforts. And now the society holds during each year three public exercises, consisting of a special session in the fall term, an annual exhibition in the winter term, and an address, given by some person selected by the society, in the spring term. It is needless to say that these exercises have always been well attended and appreciated by the public.

Such are the brief outlines of the society's history. Although it has long been regarded as the foremost society in the College, it can hardly claim such a position now, as new societies have sprung up which are justly claiming equal commendation in literary work. Its usefulness, however, bids fair to increase, because its true members ever heed the truth of the motto: "Labor Omnia Vincit."

The following is a list of the presiding officers:

\section{PRESIDING OFFICERS.}

1868-9-J. P. Shannon, I. P. Johnson, M. R. Mudge, A. J. White. 1869-70-C. O. Whedon, O. P. Hipple, S. D. Houston, W. R. Smith. 1870-1-C. O. Whedon, A. W. Webster, J. Kimble. 1871-2-P. F. McClure, S. S. Caldwell, P. F. McClure, A. Todd. 1872-3-A. J. White, Sam Kimble, S. Chenowerth, Sam Kimble, W. S. Ward, H. S. Maynard.

1873-4 J. E. Willis, G. T. Martin, E. L. Thorpe, Jno. Rogers. 1874-5-

1875-6-M. F. Leasure, L. B. Rogers, A. R. Oursler, M. F. Leasure. 1876-7-J. E. Williamson, L. O. Hoyt, John King, R. A. DeForest. 1877-8-A. N. Godfrey, A. Todd, B. Anderson, L. A. Salter. 1878-9-J. Mann, C. M. T. Hulett, H. E. Rushmore, C. E. Wood. 1879-80-N. A. Richardson, D. S. Leach, A. Beacham, M. A. Reeve. 1880-1-W. Knaus, G. F. Thompson, W. S. Myers, S. C. Mason. 1881-2-J. C. Allen, M. T. Ward, F. W. Bevington. 1882-3-J. W. Berry, L. W. Call, J. D. Needham. 
1883-4-J. W. Shartel, J. H. Calvin, C. L. Marlatt. 1884-5-A. Lewis, F. A. Hutto, C. D. Pratt. 1885-6-J. B. Brown, D. G. Robertson, C. M. Breese. 1886-7-J. E. Payne, F. H. Avery, W. J. Burtis. 1887-8-E. H. Snyder, C. E. Friend, A. A. Mills. 1888-9-W. R. Browning, H. S. Willard, W. H. Olin. 1889-90-E. T. Martin, G. E. Stoker, John Davis. 1890-1-K. C. Davis, H. W. Avery, S. N. Chaffee.

ROLL OF MEMBERS.

91.

W. S. Arbuthnot, H. W. Avery, J. N. Bridgman, C. A. Campbell,

H. F. Avery,

E. R. Burtis,

H. Darnell,

W. H. Edelblute, J. Frost,

A. K. Barnes,

E. M. S. Curtis,

D. T. Davies,

A. Dickens,

M. L. Dickson,

W. S. Dille, J. E. Dorman,

E. L. Beard, W. Brown, E. A. Clark, J. W. Evans, C. S. Green,
S. N. Chaffee, P. S. Creager, K. C. Davis, A. A. Gist,

'92.

G. C. Gentes, J. W. Hartley, L. S. Harner, R. C. Hunter, C. A. Kimball,

'93.

R. C. Harner,

A. S. Houghton, M. F. Hulett, M. W. McCrea, . S. R. Moore, A. F. Neimoller, C. W. Pape, C. F. Pfuetze, '94.

Phil Hay, G. R. McLeary, P. H. Pagett, C. R. Pearson, W. W. Robinson,
D. C. McDowell, P. C. Milner, J. O. Morse, A. J. Rudy, H. V. Rudy.

F. S. Little, D. H. Otis, B. H. Pugh, E. W. Reed, W. T. Taylor, W. P. Tucker.

F. E. Rader,

I. A. Robertson,

C. B. Selby,

G. W. Smith, W. H. Stewart, G. K. Thompson, W. M. Town, J. C. Wilkin.

T. B. Sears, F. Shaw, H. B. Walter, J. M. Williams, C. D. Young, C. $O$. Whitford. 
THROUGH JUSTICE WE CONQUER.

[Oration Delivered at the Webster Exhibition, 1891, by J. O. Morse.]

For years the struggle between justice and force has been waged. Despotisms have been overthrown, nobilities destroyed and slavery abolished; but still, here in our country, where every effort has been to forward justice, and protect the rights of men, we hear the cry of oppression.

l'he colonists had no sooner gained independence from the kings of England, and established a government on free principles, than the slavery question was brought before the people. Justice clamored for its abolition. Force, backed by custom, by tradition and by religion, demanded its continuance. The struggle was long and bitter, but in the end the black man walked forth, a citizen another star was added to the crown of justice.

A quarter of a century has passed since that bitter strife. Material growth has been unparalleled. Mighty corporations have sprung up, and justice is again called to protect the weak from the crushing power of the strong. Well may men ask, how long is this struggie to last? Will justice never conquer? Will every victory be won only to find the enemy entrenched in stronger works? True it is that in the past every victory has been followed by a fiercer struggle; that the sceptre of the king is gone, but the sceptre of wealth is here; that the nobility of birth has been destroyed, but the nobility of dollars is growing stronger; that the sale of men has been forbidden, but the control and sale of labor still goes unpunished.

By these changes humanity has been greatly benefited, but at the same time the social questions arising from the new conditions are far more difficult than those that have been settled. The evils of monarchies, of nobilities, and of slavery were destroyed by destroying the power that made them possible. The abuse of the power of wealth must be remedied without destroying that power. Corporation and monopoly must be made to respect justice, and at the same time be allowed to retain that force necessary to carry on the great enterprises of to-day.

Many urge that the relations of capital and labor can be regulated only by the law of supply and demand; that the opportunities 
of the laborer are all that can be asked; and his own idleness and vice are the causes of all his misery and want. It is a sad fact that there are hundreds of laborers who waste their money and strength in the grog shops, leaving their families to starve or recruit the vast army of paupers and criminals. But there are thousands of others who work and save for years, who give the best of their lives to their employers, and in the end are forced to see their families driven from their homes. Shall we deny these justice because there are some black sheep in the labor flock?

True the relation of supply to demand is the natural regulator of wages and prices, and, if allowed to operate unrestricted, would doubtless be just. But is this allowed? No. The law of supply and demand of to-day means nothing more than the arrangement that will bring the greatest profit to the monopolies in control, and this with no regard to justice. "But still capital does not override labor. All have equal rights in making the laws. If the laborer does not want to work for the wages offered, he can go elsewhere. If the farmer does not want to sell for what he can get, he is at liberty to keep his produce." These are plausible arguments, but if you would be convinced that something is wrong, go to the cities and look at the class that has not enough to eat. Look at the factories that have shut their doors and turned their employés out because the law of supply and demand was lessening their profits. Go to the farming community and hear the complaint of "no market."

An over-production and people going hungry in the same land, with modern means of transportation, is an absurdity. Logic may not be able to find the fallacy in the argument that says this is just, but the conscience of every man tells him that the fallacy is there. Nothing is just that allows some men millions while others starve. It is not liberty to tell the laborer he may work for a dollar a day or quit, when he has a family to support. It is not liberty to tell the farmer he can sell at prices to the very bottom or keep his produce, when he has a mortgage to pay. The laborer has to work. The farmer must sell. And the man or the corporation that takes advantage of these facts, and forces them to take less than their commodities are worth, commits an outrage on justice and is an enemy to society. 
Justice does not demand the equal distripution of property. The capacities to accumulate and utilize wealth are as varied as the natyures of men. To say that one man should own no more than his neighbor would be as absurd as to say that one writer should produce no better articles than another, or that no scientist should make more discoveries than his contemporaries. The effect of this would be to kill industry and ambition, and retard the development of our countwy " It is the duty of exery man to add to the wealth of the world as much, as his ability, will allow, and when, like the scientist and writer, the moneyed man will use his speciall ability to improve and increase the comforts, of his fellow men, there will be no complaint

Modern society gan ibe maintainad only by the centralization of power, but does anyone believe that we cannot have a great commercial center without a suburb of misery and want; that our great manufactories can be operated only by keeping the employés at merely maintenance wages; or that the tramp is a necessary adjunct of our great railway, systems?

It is not an answer to the demands of the laborer to say that they are better off than those of any other country, or any other time. No one doubts this. The question is, are they as well off as they should be? Do they get their honest share of the returns from the great industries they represent? Have their comforts been increased in as great a ratio as the products of their labor? I fear that these questions can only be answered in the negative.

The laborers do not wish to scatter the wealth and break the power that moves the great industries of to-day, but they do ask that this power may not be used to rob their families of food and homes, and it is the duty of the government to see that this request is granted. Legislation should not attempt to keep men from amassing great fortunes, but it should prevent their using this power in subjugating their fellow men and in demoralizing society.

The unscrupulous may always strive to maintain themselyes by force, but let us not despair. For every victory af justice is rewarded by a higher civilization and a happier people. Thesse are the victories that have changed despotisms to republicis, slaves to citizens, and it is by these alone, that the children can be taken from the factories and given to the schools, that the hovels may be 
swept from the land and homes raised in their places, that the scales of justice may be made to balance between labor and capital, and the wail of misery and the cry of oppression be forgotten.

\section{WHITVILLE.}

Patient peruser, have you ever heard of Whitville? For the benefit of the unfortunates who bave not, it might be well to state that it is the name applied to a boarding house located not far from the College gate, and run by Whitney, or rather by his wife.

Whitville has been the scene of many a "tear." Its walls have listened to deep schemes, beld many a riotous crowd, and have seldom witnessed hard study. Many a time and oft has the unsophisticated "first-year," sweetly slumbering in the arms of his secondyear room-mate, started from his downy boarding-house couch, and with glaring eyes and bated breath, stammered "wh-wh-h-ats ththat?" only to be told: "nuthin' but Whitville broke loose."

Boys may come and boys may go, but it is firmly believed that the crowd that made Whitville its habitation in '87, presents an anomaly in the history of the College. Not for scholastic research and philosophic profundity. Oh! no. Just the reverse, in fact.

Who of that motley crew will ever forget the attempt made by a couple of "town boys" to go with "our girls?" Whitville had two young lady boarders that year, the pride of the College, the joy of Whitville. The young men of the place numbered fifteen. When, as it occurred once or twice, those "town boys" returned with "our girls" from some convivial meeting, and hesitated at the front steps for half an hour or more, to commune about the starry flocks that roam the azure meads of heaven, then it was that ghostly forms might have been seen in the rooms above in hurried consultation; others flitting from room to room, rousing sonorous sleepers and leaving them with the injunction to "bring something." Freeman's room and Arbuthnot's, which were directly above the front steps, were the base of operations that will be left to the imagination. There were no more astronomical observations from the front steps.

The successors of the young men alluded to above were Carl 
Friend and Teddy Nichols, of the class of '88. At first these gentlemen fared no better than did their predecessors.

One evening, while making their regular weekly visit, the idea was conceived that a serenade would be an eminently proper thing with which to entertain ou visitors. H. E. Robb had one of the finest baritone voices in our company. It resembled a mixture of the filing of a saw and the beating of a pie pan. "Bob," however, declined our urgent invitation on the ground of a slight bronchial trouble, and his rival and collaborator, Whitney's big tom cat, was pressed into service. The cat, equatorially suspended from the upper story and manipulated by Arbuthnot and Dixon, was soon made to execute a series of performances in chromatic scales, runs, trills, quavers and demi-semi-quavers that made Bob turn pale with envy.

In a fer diplomatic interviews that occurred soon after, it was agreed that Whitville would cease hostilities if presented a box of cigars. The box was soon forthcoming, and then followed a scene in which the biter was bit.

All of the boys assembled in one room, each determined to have his share. The cigars were quite robust. As several of the party were indulging in their first experience in that line, it was not long before the cigar was the stronger of the two. Were the writer to live till the top of his head was as bare as a billiard ball, and his face as wrinkled as a dried potato, he would never forget that night, for he was the first to seek the outer air and pace the road, while he tried to calm rebellious nature. It is in such moments of anguish that the wayward boy thinks of home and mother, and longs for something to calm the surging billows of his soul and of his stomach too.

The above incident calls to mind Breese's cigar. Breese, who married soon after graduation, joined the faculty and sank into oblivion, one day sent to town by one of the boys for a cigar, giving as an excuse that his tooth ached, or the flies bothered himsomething in that line anyhow. A short time before, he had been delivering a series of after-dinner speeches to "our girls" on the evils of drink, the vileness of the tobacco habit, and so on, adl lib. $\mathrm{He}$ was just concluding an animated elucidation on some kindred subject, when the messenger arrived with the cigar and an empty 
whisky flask which he had picked up by the roadside. It was suggested that the two be presented to Breese in the presence of the girls. One of the boys rushed into the parlor, and before Breese could get away, gave him the articles, with the explanation that "he could not get the bottle filled." The expressions of ferninine amazement, both facial and vocal, baffle description. Breese, it was understood, spent the best part of that afternoon in profuse explar nation.

Did you ever hear of Ben Skinner's flirtation? One day during the spring term, some giddy girls were going past Whitville, ostensibly in quest of flowers, when they were seemingly attracted by Phil Creager's beaming countenance, which was in juxtaposition with a convenient window at the time. They made some move with a handkerchief. The news spread like wildfire that we had been attacked, and Whitville immediately flew to arms. The windows were crowded with excited youths frantically fanning the air with handkerchiefs, towels, pillow-cases - anything to make a demonstration. Someone suddenly looked around, when lo and behold! there was Skinner, evidently laboring under great excitement, furiously tossing a bed sheet. It was agreed by all that a man whose pent-up feelings were: such as to require a bed sheet for their expression when an ordinary kerchief sufficed for common mortals, should have free and undisputed sway in giving vent to the same. Skinner reigned supreme.

The time that Freeman's black eye, caused by a judicious application of burnt cork and carmine, but attributed to the pugilistic skill of Teddy Nichols, came so near dissolving one of "our girls" to a saline solution when sbe "poured herself out at her eyes,"the pillow fights in the parlor-the midnight raids on the pantry the buckwheat cakes-all will linger in the memory when even the subjects studied at the time will have faded into dim forgetfulness.

A few short years have gone, and Whitville of ' 87 has scattered far and wide. Some are married, others want to be, and others ought to be. The time is not far distant when time shall have silvered the heads, though perhaps not the pocket-books, and dull care furrowed the faces of those remaining. Those who live to see the dim twilight of life, will no doubt in reminiscent moods find memory diligently but vainly seeking for scientific truth or scholas- 
tic lore amid the ponderous tomes of human learning, yet will she come with all her garnered store of boyish pranks and youthful follies when the gentle zephyrs in that evening of old age, blowing through his whiskers, seems to softly whisper Whitville, Whitville.

Anon.

THE IONIAN GIRL.

The Ionian girl's a queer girl,

The queerest e'er l've seen,

And the queerest I expect to see

Long months and years between.

Her ways are very charming.

- Her manner debonnair,

Yet she will talk an hour or more,

And ne'er " address the chair."

She will write a brilliant essay,

On a subject broad and deep,

But talk to her of "yeas and nays,"

And she soon will be asleep.

She will tell you of the first crusade,

Its date, its fate, its cause;

But she's clear beyond her mental depth

When she tries to quote "by-laws."

She is witty, she is pretty,

She is modest, yet is wise;

But she can't tell what's "before-the house,"

No matter how she tries.

She will give an apt quotation,

And tell you what it means ;

But of Roberts' Rules of Order,

She don't "know beans."

P. S. C.

TRIALS OF A SENIOR.

Since college life for me commenced,

There's been no time, I ween,

When misery was so much condensed-

So little joy was seen.

The thoughts of Ag. are hardly thro',

'Till yet more dreadful things

Are bundled up in Orton's Zoo,

And make me wish for wings. 
In his most despicable works, We read of snakes and frogs,

Of spiders, scorpions and squirts, Of turtles, whules and dogs.

We learn of Tetradecapods, And Tetrabranchiata,

Of Pulmonates and Pterapods, And Prosobranchiata.

Amphioxus, Hydrozoa, Eutomostracana,

Tunicata, Vertebrata, Rats Americana.

And last, most horrible of all. We have to cut them up, And if we find they sup at all, To tind on what they sup.

Investigate them all about, By set rules most specific, To see if nature cut them out, On basis scientific.

If this were all, I'd not complain, I'd bear it with good grace;

But as its not, what wonder, then, That tears roll down my face?

For, soon as we are through with Zoo, We to the "den" repair,

And hunt for cells, until we do Give up in dire despair.

We propound theories, vast in scope, About lire protoplasm;

Then slap it under a microscope And watch it have a spasm.

On Wednesdays Olin claims his share Of our most precious time, And makes us, one and all, declare $\mathrm{His}$ cheek is most sublime.

And then, to cap the climax, The ten-cent Friday Iunches Our poor, defenseless stomachs tax. And roll them into bunches. 
Then, when at n'ght our weary heads

Begin to droop and doze,

Dark phantoms haunt our very beds

And mar our sweet repose.

However, 't will not always last, At least, that's our belief,

For ere the spring is fairly past, Commencement brings relief.

P. S. C.

\section{THE SOCIAL OF THE FUTURE.}

According to my notions of the eternal fitness of things, the college of the future will be a very different affair from the college of to-day. With the growth of the college, with the increased number of students and their increased appreciation of social advantages, the college social will rise from its present position of mediocrity and take its proper place as foremost among the society events of our pleasant little city.

It will cease to be a cross between an agricultural chicken show and an amateur representation of Romeo and Juliet, in which "music, literary exercises and friendly greeting find place," and will rise to a higher and more dignified plane. At the college of the future, there will be present, besides the students and faculty, the governor and lieutenant governor, the Board of Regents, the senior class of the University, and many individual friends of the students.

The gentlemen will appear dressed in swallow-tailed coats, barn door shirt fronts and white vests; while the ladies will be attired in full dress, abbreviated collars, twelve-button kids and all. The social will open up with a grand ball in the new and spacious hall built especially for the purpose, through the praiseworthy efforts of our "farmer legislators."

The college military band, which includes a superannuated French harp and a tuning fork, furnishes the music for the dancing, in which all enthusiastically engage.

The seniors lead out the sophomore maids,

The preps "sushay" with the faculty's wives,

Then each and every one promenades, And "allemande-loft" for all their lives. 
The dancing amusement will have emerged from the embryo skip-to-my-loo of the present to the dignified minuet and stately quadrille. The musical voices of Professors Popenoe and Lantz will be heard ringing through the hall, as they call the intricate changes of the moniemusk and Sicilian circle. President Fairchild will be there looking younger than ever, and it will be a pleasing sight to see him as he walks across the hall with a blushing young first-year clinging confidingly to his arm. Mrs. Kedzie will be there, and Mrs. Winchip, and Professors Walters and Georgeson and Kellerman and White, all lively, jolly, joking, dancing, enjoying themselves as in the days of their youth.

The affair will close with a grand banquet, which will of course be the "entire production of Mrs. Kedzie and her girls," and consequently will not overtax the gastronomic capacities of the guests. Toasts something like the following will be heartily responded to:

"The health of the Governor."

"The health of President Fairchild."

"More to eat for Friday lunches."

"Our Alma Mater."

"Kids under twelve not wanted."

"Our Alliance Legislature."

After supper everyone will join in the old-fashioned Virginia reel, the national anthem will be sung, and at three o'clock in the morning

The College bell will toll the coming of the day,

And preps and sophs and all will tear themselves away;

and thus will end the college social of the not far distant future.

C. J. D.

WEBSTER GLEE.

[Composed by T. E. Wimer, member of the clase of '90, for the Webster Annual, of 1880.]

The Bay State may sing its fair praises to Harvard, And Connecticut sing of her time honored Yale, But we'll laud the name of a dearer old College,

In the land where the sunflowers nod in the gale.

Chorus.-For we're boys of the Sunflower State, ha ha.

For we're boys of the Sunflower State, ha ha.

And we love, don't you see,

Our dear K. S. A. C.

For we're boys of the Sunflower State. 
You may sing of the glory of Kings or of Princeton,

Of the grandeur of Kenyon, of Union, or Lee,

But there far ubove in her own splendor shining,

Beams kindly and brightly, our K. S. A. C.

Chorus.-

We may wander afar from the scenes of our boyhood,

Our lives may glide on as the brook to the sea,

The days of our youth may be gone and forgotten,

But memory will cherish our K. S. A. C.

Chorus.-

And when life is o'er, and the dark, silent boatman,

Rows a'er the still river for you and for me,

When we step from the boat and the loved ones are greeting,

We'll meet with the Wersters of the K. S. A. C.

Chorus.--For we're WeBstens of the K. S. A. C., ha ha, For we're Webstels of the K. S. A. C., ha ha,

And we love, don't you see,

Our SOCIETY,

For we're Websters of the K. S. A. C.

I stood by the gate in the morning

As the bell was ringing loud;

The preps came in from the city

And passed by in a noisy crowd.

And like those joyous first-years, Those noisy girls and boys;

A crowd of thoughts came o'er me

And filled my heart with joys.

I thought of them all in chapel

Hard listening to a prayer

In behalf of civilization

And its advancement everywhere.

T. C. D.

Little oval goose eggs,

Little tens, so rare,

Make a student homesick,

Make him almost swear.

EXAMINATION DAY.

When my winks in vain were wunk,

And my last stray thoughts were thunk,

Who saves me from a shameless flunk?

My pony! 
OUR INTELLECIUAJ, DEVELOPMENT.

[Oration delivered at the Webster Specia], 1889, by Geo. E. Stoker.]

The present century marks the greatest progress of any epoch of the world. The laborer has been lifted from serfdom, and our increased wealth has raised the poor to comfort. The scientific investigator has been released from the clutch of superstition, and the theologian and proiessor have been elevated to planes where their wealth of thought accelerates the tread of human progress. Prosperity has increased, and with it has come a flood of improvements which astonish the world with their marveluus results. Advancement is the universal law of humanity. Each generation begins the life struggle from a higher basis, because it has inherited experience. Two thousand years ago the strong in state were the men of physical power. Matters of the greatest moment were settled by the sword upon the battlefield, and the test of supremacy lay in one's power to destroy. War was the occupation of the race, and amid its tumults and carnage men sought glory and gratified their highest ambitions. The world has changed. Out of the darkness of the past we have emerged into the light of a better day. The philosopher appears upon the stage, destined to rule the world by thought. This idea of growth by thought develops. Development has brought progression, until to-day the strong in mind are our heroes. The pleaders, the orators, the writers, the intellectual prize-fighters are the great men of our time. Thus we are inclined to boast of our phenomenal growth, yet we always look to the future for the "golden age." We believe that there are greater victories to be won. We believe that through the coming centuries the wars that are waged by thought upon the intellect will be the means to a ligher end for man. This is why humanity looks forward with a delightful charm to the conquests on the great highway of life, and from the elements of which there is no escape if any true citizen to his country wish to live. It is in the present stage of civilized life that the individual grows. It is now that the inclependent man enjoys his right to life, his liberty of conscience, his freedom from the burdens of cast and privilege, and the cruelty and injustice of despots and kings. Hereditary privilege has been ground to the earth by the march of mind, and in its 
place has sprung up liberty in thought and expression. Self-government has triumphed, and the sturdy and indomitable race that builded it are untiring in their efforts for future betterment.

It is this spirit of the American people that has given our nation its preëminence above all others. It is this spirit that united our people to put forth one mighty effort that broke the chains which fettered a million slaves, and with one voice proclaimed that every man should have the right to vote, and proved it. ' It is the same spirit that we see to.day in the demands of the masses The common laboring man with all his power asserts his right to a better recognition. The one great aim and end of his life is to become elevated in his race, and, seeing his employer with better advantages for gaining the same end, creates an inevitable conflict. This is a form by which the great problems of labor and capital take their rise, necessitating trades unions and labor organizations of every type for the protection and advancement of the laborer and artisan, causing strikes and riots and boycotts, and resulting in envy and hate and prejudice detrimental to the welfare of all. It is a condition in our system that is a danger and a menace to society. But are these problems and difficulties to have a lasting existence? Reasoning from the past we should say, undoubtedly, no! Men of our day "have lived to see the laws repealed that had made outcasts of the noblest, the wisest, and the best;" they may see greater results. The doctrines of the anarchist and the diseases of the nihilist cannot long bear up against the obstacles they meet in this free country. Popular prejudice is against them, and even now we revert with distress to the gross injustices that have followed their course.

Science has done much, in many ways, to obviate these difficulties, and thus bears an important relation to the great industrial affairs of life. It has not been long since science was released from the clutch of superstition, but from that time man has progressed faster and reached greater eminence than at all future periods combined. By the illumination of the torch of science, man is able to make progression, able to become victor over nature. By its aid the once invincible problems of matter are now solved by the simplest arithmetical formula. It arouses by its presenta- 
tion of ideas, its theories, antagonism with the theologian and the learned professor of the arts. It sets forth the theory of evolution upon a firm and reliable foundation. It has said that the fittest does survive, and with universal facts for reasons shows us how.

Thus how interesting to us becomes the struggle of modern times in thought. It awakens the world by its mighty forces in united action, and bewilders the mind with its marvelous achievments. The champions of the orthodox creed themselves, find ground for great dispute. Out of their sanctuaries have arisen the two theories of the old and the new schools of theology, yet the expounders profess alike to be the followers of the true reformers. They both alike abjure the doctrines of formalism, and adhere to the good of spiritual religion.

All this reveals a story to the human race. We must unite in universal brotherhood to act out the drama that has been prepared for us. Behind us is a vast expanse of human effort and progress, mingled with atrocities and crime and bloodshed, emanating from darkness and gloom. The present with its achievement lies around us, majestic and proud. Before us, reaching out and on into the countless years of an unknown eternity, is the field upon which we are to conquer, or to be conquered by, the antagonists of time. There are fields of conquest for every human being. Responsibility rests upon the shoulders of the people of the present. Through them are to work the problems that will influence their future generations to worthy or ignoble purposes. Let us not be short-sighted to the position we occupy, but profit by the experience of the past. That there are conditions of injustice and depression we are all aware. In spite of our intellectual advance, there are traits and attitudes of conflict and crime, and the many have to suffer for the elevation of the few. But the hand upon the dial,points towards a better future, and we are confident that through the never-ceasing efforts of the race, our path of progress will be upward. 


\section{COLLEGE HOME. \\ AIR-HOME, SWERT BOME.}

Oh, the old college halls where wisdom we gained, When as students by our alma mater claimed;

Where she taught us to scan with devotion the page

Enriched with the lore of some bright elder age.

Our hearts, 'mid all changes, wherever we roam,

Ne'er lose their love for that old college home.

Chorus-Home! home! college home.

Our hearts ever yearn for our old college home.

'T was here too we found friends reckoned most dear,

Whose hearts to our own have seemed ever since near.

How we walked, how we talked, by moonlight and shade,

As unconscious of time, together we strayed!

Far brighter to us than palace or dome

Are these solid old walls--our loved college home.

\section{Chorus-}

But now our old home, as if not the same spot

Is the same in itself, though its inmates are not;

And we feel like strangers 'mid objects well known,

And nothing we see seems to be now our own.

Yet still to our hearts sweet memories will come

Of the days that we passed at our old college home.

Chorus-

Sam Kimble.

Little oval goose-eggs,

Little tens, so rare,

Make a student homesick,

Make him almost swear.

\section{EXAMINATION DAY.}

When my winks in vain were wunk, And my last stray thoughts were thunk, Who saves me from a shameless flunk?

My pony. 


\section{SCHOOL LAST ATTENDEI).}

In filling out the blank pedigree during the examination for admission to the College, when I came to the line "school last attended," not even the excitement naturally attending the youthful granger's first examination could drive from my mind the many circumstances connected with that school. The inquiry was answered by the single word, distinct, but oh! the inadequacy of the word to convey an impression of my alma mater. The institution of learning and kindred sports of which I speak is like our country, on a hill and cannot be hid. I have thought it would be better if it could.

This hill is much like the one on which the battle of Gettysburg was fought. It has its seminary, innumerable little round tops, a peach orchard, and, scattered around among the peach trees, a cemetery. School was always dismissed for funerals, so the pang of losing a dear neighbor was not wholly unalloyed. Our school house stood remote from other buildings, surrounded by boundless stretches of rolling prairie, which offered no obstacle to the observation of its weather-beaten form, its broken siding, its dilapidated chimney and its general aspect of forlornness.

The building was a simple one; no paint, no plaster adorned its walls; no entry or cloak room had ever been built. Each boy brought his hammer and a tenpenny nail and manufactured his own hat-rack. A hitching rail was all the fence our school grounds ever had. It was put up one winter when a lyceum flourished on Gravel Hill. Alas! so prevalent were the answers, "Not prepared," that our little society died of innocuous deseutude, as it were, the hitching rail alone remaining for us boys to jump over and for the worms to feast upon.

There is a romance connected with our old school, and I was one of the romancers. The romancess was a little red headed girl by the name of Lucy, and I was mashed on her. We didn't call it that then, but that was what it amounted to. Well, it's the same old story. We romanced around there for three or four years and then I came to College. I hadn't been here six months till she eloped. What pains me most is that the fellow she eloped with wasn't $I$. 
I well remember the last day I spent at "No. 15." We had a dinner. I graduated that day, although I didn't know it then. When dinner was over and the dishes were cleared away, we had our declamations. Oh! how my heart swelled with enthusiasm as I caine to the front with "When freedom from her mountain height." But it was soon all over, and slowly we wended our way homeward across the prairie. I cannot boast of the size of our old school building, of the number of its students, or of the high positions that its graduates fill; but when I think of the many happy times I have there enjoyed, I feel that it shall ever be cherished in my heart and revered in my memory.

J. B. Brown.

ONCE MORE WE MEET.

AIR-AMERIOA.

Brothers, once more we greet

Our learning's chosen seat-

Old College Hill.

Come sing a joyful song,

With voices deep and strong,

'Till the echo shall prolong

The Choral rill.

From wrestle, toil and strife,

In dusty streets of life,

We hither come.

Here in these calm retreats,

Brother with brother meets,

Our alma mater greets

Her children home.

At her domestic hearth,

That dearest spot on earth,

We take our cheer.

Feeding the holy fire,

That never shall expire,

But blazes purer, higher,

With every year.

Sam Kimbie. 


\section{STRAY REMINISCENCES.}

It is interesting to notice how the progress of any given student in the College resembles the movements of the hands of a watch. As a member of a certain class, the student moves in an unvarying round of fall term, winter term, spring term, and then back to fall term again; while the class has moved a point, like the hcur hand of the watch - the first-years becoming second-years; the second, third; the third, fourth; and the fourth-years, having attained to the required degree of 70 , and having exposed their ignorance in a final oration, are ready for the "blind pig."

But, although the class as a collection of individuals may change in a remarkable degree, yet any class, as the representative of a certain year's work is almost exactly the same as its predecessors have been since the College was founded. The fourth-years continue to look down upon the third-years with an air of condescension not entirely unmixed with jealousy, and the latter, in turn, view the sufferings of the second-years with exultant feelings which are total strangers to pity, even when the foremen, in order to keep the pay-roll well within bounds, work what is known as the "instructive racket." The same old ripple of merriment runs over the faces of the audience when the president, at the beginning of each spring term, announces that the P. M. squads will be formed immediately. Even the task which the farm division is first employed upon seems still to be a bugbear to the P. M. boys, the only change being that the motive power in the wonderful feat of engineering is now a nobby span of horses instead of a pair of bony old mules.

And right here let me remark that in the death of those old mules the farm boys lost one of their best friends and allies. The P. M. squads for twelve years previous to ' 88 owe them a debt of gratitude which can never be paid. Thumped, hammered and cudgled, they still heroically held to their regulation pace, thus reducing the number of loads of non-commercial fertilizer necessary to be spread, to a minimum. They were poor and old, and possessed but few of the attributes of beauty, as we ordinarily understand the term, but as one of our assistants once said after riding one of them to water, they had plenty of backbone, and 
would not be bulldozed into more work than comported with their sense of dignity.

The saine old jokes that were perpetrated upon the members of the faculty five or ten years agro, still do duty, although somewhat the worse for wear. For instance, that advertisement of patent hair renewer has lost the part which warrants it to grow hair on a billiard ball in thirty days, and it is confidently hoped that in the course of time the ad. will disappear altogether, and in consequence, people will be allowed to wear their cranial covering in any fashion they may see fit.

The brilliancy of their showing, however, is slightly dimmed by the manifest retrogression in other directions. For instance, in former years, when, after one of our tirades against the present text-book in Ag. Chem., we were asked to name a substitute, we were ever ready to suggest Webster's Unabridged, or Fairchild's Moral Philosophy, while the present third-year class have not as yet sufficiently recovered from the effects of its perusal to more than murmur, "Anything, Lord!"

I am beginning to fear that this article will hardly pass for reminiscences, from the fact that it contains so little that is suggestive of bygone days. However, I am consoled by the thought that it will be a little out of the ordinary line of reminiscences. In fact, I feel like the boy who was observed intently at work with pen and ink, and who, on being questioned as to what he was doing, replied, "I'm writing a comedy. I've got to the last act, and I'm killing off the characters."

"Killing off the characters, Willie! Why, they don't do that in real comedies at the theaters, my son."

"I know it, papa. That's where my play is just going to knock the socks off of most the plays you see in the theaters." P. S. C.

The prep stood by the class room door,

Whence all but him had fled;

Examination day had come

To aching heart and head.

Yet beautiful and bright he stood,

With manly form and pose;

An honest look upon his face,

A "pony" in his clothes. 
We are often told how we may be as "fresh as daisies" on Monday mornings, but there are lots of blooming first-years who are fresh as daisies all the time. Won't someone now please tell us how to curb their freshness?

\section{CLASS OF' '91.}

Oh, gracious muse, lend me thy art, That I may fling a fiery dart, At those whom preps and fourth-yenrs shun, They're called the class of ninety-one.

'Twas in the fall of eighty-seven, There entered here two hundred eleven First-years, that were as grassy green As any afore or since were seen.

But when one year had rolled around, T'heir praises loud they did resound; And many a bright and boastful Soph Thought himself wiser than a Prof. Hard they worked at Algebra, To make Prof. Luntz look wise and say"Of all the classes 'neath the sun, The brightest is the present one."

At length, when P. M. days are nigh, They all hard with each other vie, The irksome task to barely shirk And still get ten cents for their work.

Another summer now is passed, When, 'round the College gathers fast Freshmen, Sophomores, Seniors too, But worst of all, the third-year crew. Just one more glance before we pass: Suppose it is the Ag. Chem, class. We see Prof. Failyer scowling black At the note that's pissed behind his back. Loud and deep then doth he roar,

"Never a junior class before, In all the years of my long reign, Have been so destitute of brain."

Another year, and now we see This same old crew convulsed with glee; For soon their college days are o'er, With lessons they'll be bored no more.

E. W. REED. 


\section{TYPES OF STUDENTS.}

Among five hundred young people gathered together for educational purposes, it is always possible to find several varied and distinct types. First, there is the "tough." $\mathrm{He}$ is the hardest to define, the hardest to describe and the hardest to reform. He is of no particular size, of no particular build, of no particular degree of intelligence, and varies infinitely in his symptoms of "toughness." So far as my limited knowledge extends, no attempt has been made to classify him, although some make a distinction between fourthyears and other "toughs." Fourth-year "toughness" is innate, unadulterated, full strength and non-repressible; while ordinary "toughness" may, by the proper administration of goose-eggs, sarcastic remarks, or open rebuke, be alleviated, if not entirely eradicated. The fourth-year confidently believes that he is the pivotal center about which the whole College revolves in profound humility and humbleness of spirit. You may dip the ocean dry with a teaspoon; you may play equine barber without detection; you may corral the infinite, and even get a cinch on eternity; but you can nevereliminate from the fourth.year mind, the colossal conceit that distinguishes him from ordinary mortals, and renders him a bore to his fellow-men. I say fellow-men, because the ladies seem to be just as much mashed on him as though he were a third-year and had good sense.

Then there is the dude. The dude is a sort of a two-for-a-nickel, shave-every-day, flirt-with-the-girls young man, who wears a calico vest, two-story-and-attic picadilly collars, has brass enough on his scarlet tie to copper-bottom a full-rigged ship, and has sap enough in his head to float it. His grades average about seventy until he gets to be a third-year, and there happens to be two socials and a hop the same week, when he usually takes a vacation, and pays a protracted visit to his maternal ancestor.

In marked contrast to the dude, is the individual who, if we are to judge from external appearances, is in blissful ignorance that Ivory soap can be had for ten cents a cake and carbolic acid for even less. He invariably comes to school looking like the breaking up of hard times, and makes us one and all sigh: "How long, oh Lord, how long? How long before the ice will be out of the Blue, so this fellow can go swimming?"

P. S. C. 


\section{SUCCESS - WHAT IS IT?}

If you will take a short excursion back over the pages of history, you will undoubtedly find that there is a wide range of opinion as to the true meaning of this little word - success. It has been defined time and again, and still we fail to grasp its significance. Great men of every period have exhausted their vocabularies in framing a definition which shall be universally accepted, and each has found himself in utter solitude with his pet production.

Daniel Webster may have had his idea of what constitutes success, and Prof. Georgeson, who bas as much right to his opinion as has the immortal Daniel, may have an entirely different idea.

Mrs. Kedzie probably considers it success if she teaches the pretty second-years to properly manipulate the mush-stick, and at the same time cut up one little, insignificant, patty-pan sponge cake into a hundred and fifty-three pieces for the Friday lunches.

Prof. Lantz will probably allow one of his rarest, most exquisitively adorable smiles of successful satisfaction to permeate his whole visible anatomy if he ever succeeds in establishing the truth of some abstruse geometrical proposition which has puzzled mathematical skill for ages, as he has hopes of doing.

Even the unsophisticated prep who has been so fortunate as not to have fallen below extreme low-water mark in grades deems himself abundantly qualified to be classed with the successful, to say nothing of the universally envied sophomore who has been able to get a girl for the Ag. reception, and consequently is not obliged, as are most of the class, to wander aimlessly about, singing to a most doleful tune the following touching and pathetic lines:

" Of all sad words of tongue or pen, The saddest are these, 'I thank you Kindly, sir, but I'm spoken for.'”

The man who has made exceptional advancement up the greased pole of success, only to be precipitated into oblivion among the masses below, would probably, were he called upon, furnish us with a very pessimistic definition of the ethereal commodity in question, but he and Mrs. Kedzie, Prof. Georgeson and the sophomores would all unite in saying, with Ingalls, that "To succeed is success."

M. F. H. 


\section{COMPANY "Q."}

Yesterday in the afternoon, as I stood by the old Hort. Hall, I watched the drilling of Company $Q$; there were girls both short and tall. At first they all stood in a line, with the small ones in the rear; And when lieutenant called the roll, each one, in turn, cried "here." But when he issued the command, "right forward and fours right," At first they showed a little doubt, but this was only slight; The first four wheeled to a right about, as nice as nice could be, And never stopped or slacked their pace, until they struck a tree. The second four stood there, stock still, nor stirred a single step ; The third four made a right half wheel, and then a half wheel left. The leading guide at first stood still, and then fuced to the rear; The other guide made a movement that in tactics don't appear.

Just at this juncture, lieutenant called "halt," and then each girl stood still, And seemed to say, "I'm sure I'm right," as you know girls sometimes will. Lieutenant gusped and stood stock still, to see the fearful blunder ; With some girls here, and some girls there, and some girls over yonder. Just at this point si Mason came, and told me to go to work, He said he should call it "instructive," and hinted that I was a shirk. Slowly and sadly I went again, and sorted potatoes o'er, And fancied I saw dear company $Q$ marching the drill ground o'er. But if ever they learned to march in line, of one thing I felt sure, They'd have to quit swinging their heads and arms, and being so fearful demure.

\section{OUR COLLEGE BELL.}

The college bell, the college bell, How many tales its music tells Of wondrous feats, by labor wrought, When P. M. boys were being taught.

Those busy hours are past and gone, And many a boy that strolled the lawn, Within some office chair is found, And plows no more the fertile ground.

And so 't will be, as time rolls on, When P. M. boys have come and gone, That other bards shall try to tell The misery caused by the college bell.

They'll try to tell of famous deeds, Performed while devastating weeds; Of deeds of courage and of skill In laying siege to the cider mill. But words shall fail, no tongue can tell Of the joy that is felt when the four o'clock bell Shall sound its glad, joyful chime, And tell the boys that 'tis quitting time. 


\section{CIVIL SERVICE IREFORM.}

Friend, I write for amusement; not to amuse the public; no, that would be difficult, but for ny own amusement. I used to attempt to please, but now I never attempt a thing so unbecoming a writer of my standing. I say standing, for I seldom lie when I write. If I ever thus indulge my passion, it is because an irresistible impulse urges me onward. This passion comes to all alike, and some seem peculiarly subject to attacks of this kind. But all I wish distinctly understood is this, that I am not lying while I write this. No, my friend, I am simply sitting in pensive thought, upon a feather cushion of a reclining chair. I like feather cushions to sit on. Some prefer to lie on them, but my purely honest nature will not permit me to do so.

When about seventeen years of age, I passed through one of the most trying ordeals which ever fell to the lot of mortal man. It ran thusly: The new schoolma'am was just finishing her second week of school. She was a maiden of twenty-five summers, and experienced in all the arts to which civilized man is heir. A party the coming week at our near neighbor's made me anxious to "do something for my country." I never had ventured so far with anyone before, but resolved, and resolving to keep my resolve, insomuch that I almost dissolved, I pulled the ears of yellow corn and sang snatches of love songs all the forenoon, hoping thus to work myself up to the boiling point.

After partaking of my midday meal, I proceeded to the school house, where my longing soul was to be filled and my heart to be made happy. As I approached the house, my whole nervous system revolted, my knees smote against each other, and my heart kept thumping away at my prosternum until I felt completely demoralized. The closer I came to the house the more terrible grew my agitation. I reached the door in a comparatively helpless condition; I knocked, and, as I heard the foutsteps come tripping toward me, who can imagine my feelings? I can't. The English language won't express them. Sick distemper tyrannum vertigo El Paso Texas, is the only Latin that comes near it. She opened the door. I stood aghast; ran first one hand up the door cheek and then another, then one and then the other, and then I ran the other 
one up the other door cheek twice, and then changed from one foot to the other, and then cleared my throat. Sliding my hands upon the door cheeks all the time, I says, "We' re going to have a party at Mr. Smith's." "Yes," she said, "I have heard of it." I ran the other hand up the door cheek, and stood on the other foot. My situation was precarious. And then I said something about her company, that I had learned from a book. She said, "no," and something about "other arrangements," and, "thank you," etc.

I was unconscious. The subject weighed heavily upon my mind for years. In fact this unwarranted act of mine rendered me useless for life. Thus it is with the youth. Sorrow and calamity beset his pathway, and he pines away to nothingness. Oh! that I could impress upon every one of you the truth of this statement. Could I but rouse the molecules of your quiescent brains to hearty action and make you realize this, methinks life would not have been spent in vain.

T. E. WIMER.

President-Showing ace of clubs to erratic sophomore who has been summoned to his imperial presence: "Mr. A., will you be kind enough to tell me what this is?"

Mr. A.-After carefully examining the contraband article: "Well, Mr. President, I am not very well posted on works of art, but upon a superficial observation, I should judge that it is a poorly executed steel engraving of a blackberry."

\section{TRUTH.}

I believe that this word means the most and is thought of the least of any word in the vocabulary. It was a standing question with the philosophers for ages - "What is truth?"

It was the fundamental element in the Greek perfection - the good, the true, and the beautiful. All down the centuries we find truth dictating the destiny of kingdoms and settling the dynasty of princes. No principle, be it ever so great; no law, be it ever so popular, can long exist without the stamp of truth. Truth is eternal. A principle, a law, or a nation founded upon truth, sustained by honest hands and governed by unflinching powers of 
truth, will just so far prove permanent. All the nations that are sleeping in the dust of the forgotten past fell because truth's altars had been desecrated and error enthroned thereon.

As we turn the pages of history, on to the present time, and see the world so diligently searching for truth, and so successfully producing such marvelous results, we are awed to silence. Truth is the key that unlocks the power of the clouds, and throws open the door of the future and encompasses time and space. As we see the world advancing in this new and wonderful epoch, and behold the future freighted with pleasant possibilities, we feel that the problem is capable of solution, but realize the magnitude of the answer. This and more did the poet see who studied Nature in all her varied forms and was led to thus exclaim:

"Truth crushed to earth, will rise again;

The eternal years of God are here;

But error, wounded, writhes in pain,

And dies among his worshipers."

W. H. OLIN.

THE GRADE BOOK.

That awful book! That awful book !

Its contents ever hid from sight,

What would I give for one, good look

Upon that page of black and white!

It is the book used at the College

For summing up a student's knowledge.

That awful book! That awful book!

It has been used through all the past;

Instructors here their vengeance took,

And 'tis a custom that will last.

To steal a glimpse, no matter how,

Amongst the Profs would raise a row.

That awful book! That awful book!

A record keeps that's just and fair,

From ancient times the students shook,

To have their acts recorded there;

For with the good this grade book makes

A careful record of mistakes.

That awful book! That awful book !

Its power increasing with its age,

By rapid strides position took,

To judge all men, from prep to sage;

And now from its exalted place,

It narks the laggards in the race.

"Billiz" Knabb. 


\section{HOW OLD IS MANKIND?}

In this age, perhaps in every age, man has searched for his own origin. Scarcely thirty years ago, he was thought to be the creation of the present geologic age; now his parentage dates back into the tertiary period.

When Darwin landed on the solitary island of the Pacific and saw the naked savages in all their loathsome wildness, he thought them but one step above the apes, one advance in the sovereignty of mind over matter.

Yet upon one of the remote oceanic islands, rising bigh above the level of the surrounding country stand gigantic images of stone. Here in this island, scarcely thirty square miles in extent, are hundreds of these images slowly crumbling into dust. What do these point to, if not a previous greater area of inhabitable land and an immensely greater number of inhabitants, and more than this the form of government and development of society far above that of the savage tribes now inhabiting the islands? Surely, this case of retrogression demands an explanation. If development has always been forward and government is a sign of progress, here exists an apparent exception.

To our east, in the valley of the Ohio, stands the only remaining monuments of a totally obliterated race; a race advanced in civilization far above the roving tribes of aborigines, if we may infer anything from the accuracy with which the mounds are planned and constructed; a race whose latest history did not exist a century ago in the oldest myths and legions of the most ancient tribes of Indians. "We have here," says Wallace, "a striking example of the transition over an extensive country, for comparative barbarism, the former leaving no traditions and hardly any trace of its influence upon the latter." Have the modern Indians descended from the mound builders? If not, where has vauished their civilization?

D. G. F. 


\section{"SO LONG."}

Our work is nearly completed. For three long months we will have been at work on this modest effort. We have often been hindered and sometimes well nigh discouraged by the obstacles which we have had to encounter. None of us had ever had the slightest experience in this line of work, and as this is the first book of its kind ever issued from this College, we had not even a guide to work by. At the outset we expected to produce a grand book. We are content to call this merely an indifferent one. We had no expectations of growing rich; nor have we, as the "finale" will illustrate. We expected to learn something outside of that usually found in text books, and we think we have; at least we have learned better than to try such a thing again. We cannot say that we exactly regret having undertaken the task, but we can all say, in the words of the immortal Shakespeare,

" Before an editor again we'd be, We'd drown ourselves in the deep blue sea;

To some far off cannibal isle we'd flee, And let the savages make hash of we." 
YE EDITORS IN THE

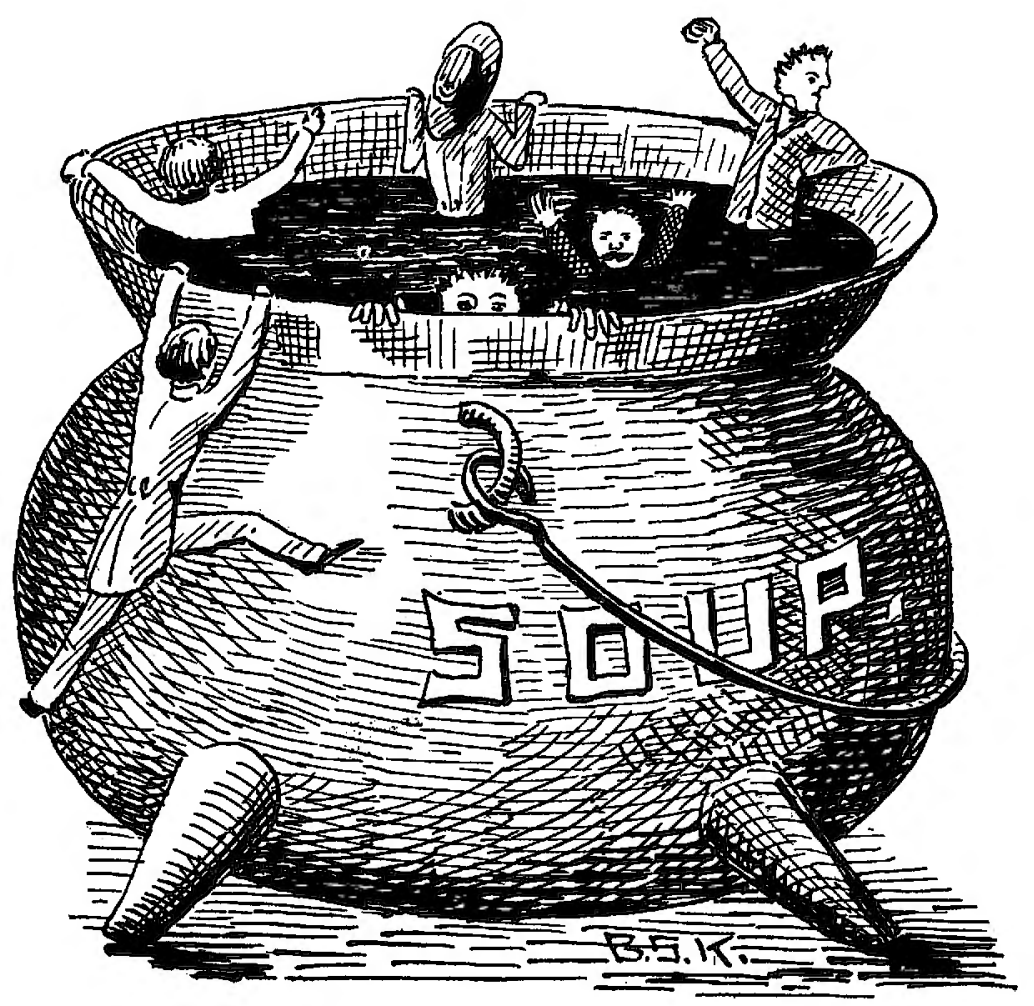




\section{CHURCH DIRECTORY.}

I'resisyelian Ciruncit.-Corner Poyntz avenue and Fifth street. Dr. D. C. Milner, pastor. Preaching at 10:30 a. m. and 7:30 p. m. Sabbath school 11:45 a. m. Y. P. S. C. E. 6:30 p. m. Good music. Students cordially welcomed.

1S' Me'Hodist Eliscoral Churcir.-Rer. J. A. Swaney, pastor. Preaching Sunday at : $0: 30$ a. m. and 7:30 p. m. Class meeting, 9:30 a. m. Sunday school at 11:15 a. m. Epworth League at 6:30 p. m. Prayer meeting Wednesday at $7: 30 \mathrm{p}$. m., followed by Bible study. Visitors are welcome at all the services.

Episcopal Cirurch.-Preaching at 10:30 a. m. and 7:30 p. m. Sunday school after morning service. Holy communion first Sunday of each month. Service Wednesdily evening at 7:30. Rev. P. Brooke, rector. Seats free. All invited.

Christian Churcis.-Elder Charles Rowe, pastor. Sunday school at 10 a. m. Preaching at 11 a. m. and 7:30 p. m. Y. P. S. C. E. prayer meeting at 6:30 p. m. Prayer meeting Wednesday evening, 7:30.

Conglimational Churcir.-Corner of Poyntz and Juliette avenues. Rev. E. R. Drake, pastor. Preaching at 10:30 a.m. and 7:30 p. m. Sunday school at 11:45 a.m. Y. P. S. C. E. at 6:30 p. m.

Union Mission Chapel.--Preaching at 10:30 a. m. Sunday school at 3 p. m. Preaching at $7: 30$ p. m. Prayer meeting Thursday evening at $7: 30$ p. m.

Bhipist Churcir,-Rev. E. S. Riley, pastor. Preaching at 11 a. m. and 7:30 p. m. Sunday school at $12 \mathrm{~m}$. Young Christian Workers' meeting at $6: 30 \mathrm{p} . \mathrm{m}$. All are cordially invited. 


\section{ELLIOT \& GARRETTSON,}

\section{The + Leading + Elotbiers,}

HATTERS AMD FURNISHERS

\section{FINE CLOTHING}

A SPECIALTY,

AND A REMARKABLY COMPLETE

ASSORTMENT OF GENTS'

FURNISHINGS, HATS, CAPS, ETC.

ALWAYS READY AND WILLING TO SHOW GOODS

321 Poyntz Avenue, MTANHATTAN, KANSAS. 


\section{E. A. WHARTON, \\ The POPULAR and LEADING \\ Dry GoOds MERCHANT \\ IN TMANHATTAN.}

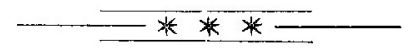

$7 \nabla)^{\mathrm{E}}$ have at all times the largest, the newest and the most stylish goods brought to Manhattan. Our store is full of beautiful new goods.

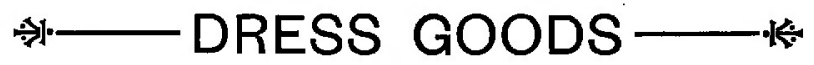

We make a specialty of, and can please all. An invitation is extended to all to call and look through our store and inspect the Finest Stock in the city.

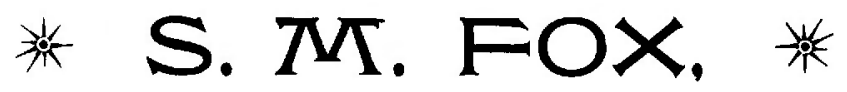

\section{Bookseller 쓰 Stationer,}

$$
\bar{W} \sqrt{N^{2}}
$$

\section{COLLEGE TEXT-BOOKS,}

SCHOOL SUPPLIES, ETC. 


\section{GEO. H. BENEDICT \& CO.}

\section{Dhoto-Zine Etehing, ‘. Map and Wood Engraving.}

ARE PREPARED TO MANUFACTURE ANYTHING IN THE LINE OF A PLATE OR ILLUSTRATION THAT IS FOR USE ON THE PRINTING PRESS, BY THE METHOD BEST ADAPTED TO EACH PARTICULAR SUBJECT.

\section{South Clark Street, CHICAGO, ILL.}

[ Benedict \& Co. have manufactured, from photographs, all the portraits and group pictures in the Symposium.-EDs.]

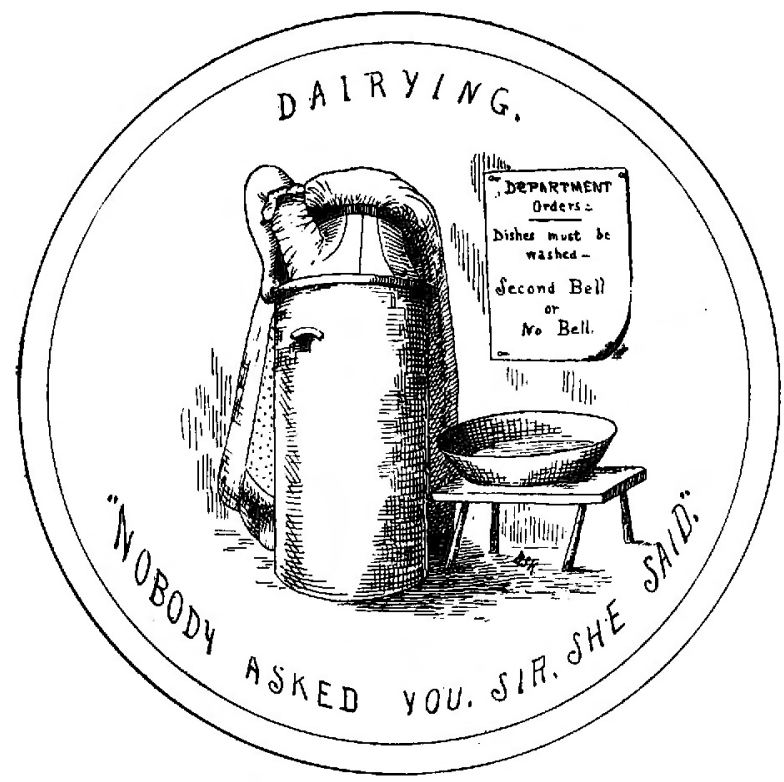


I.

Go to college,

Get knowledge.

Sheepskin,

Fame win.

I I.

Wife take,

Home make.

Buby come,

Ah! hum!
III.

All the while

We smile.

You must buy,

That 's why.

IV.

Please call,

One and all,

At HUNTRESS' store, And get more

for your money than any where else in the city.

\section{W. B LEICESTER, \\ Merchant Tailor. 藻洸棌 \\ Satisfaction Guaranteed.}

\section{SWINGLE \& VARNEY,}

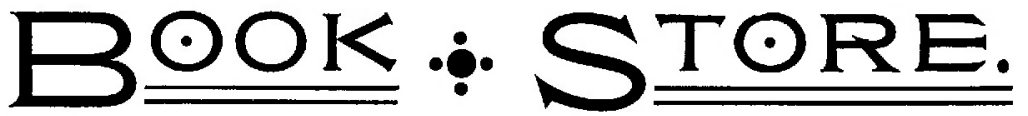

HEADQUARTERS FOR

\section{Sehool and Sollepp Text-Books.}

\section{STUDENIS' SUPPLIES A SPECIALTY.}

Call and see us. A welcome always. 


\section{GEO. F. DEWEY,}

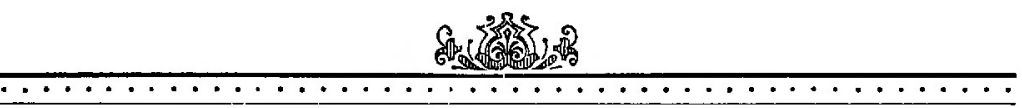

Art Photography. on

ESTABLISHED 1859.

POYNTZ AVENUE,

\section{MANHATTAN, KANSAS.}

[The photographing for Symposium cuts was nearly all done by this popular artist.-EDs.]

\section{.. THE ... \\ Ameriean System of Shorthand.}

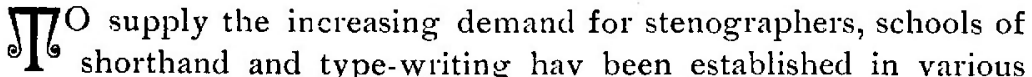
parts of the country, and, with few exceptions, all business colleges now hav a "department of shorthand." A number of systems ar taught, but that of Benn Pitman is more generally used than any other in this country, and may be called the "American system."- Extract from the Report of the Commissioner of Education (Washington, D. C.), for the Year I\$87-88, page 927 .

For catalog of shorthand publications by Benn Pitman and Jerome $B$. Howard, address

THE PHONOGRAPHIC INSTITUTE,

Cincinnati, Ohio. 


\section{J. B. MUDGE,}

+ THE +

Leading Grocer.

$\bullet$

CARRIES EVERYTHING

IN HIS LINE.

\section{DRIED FRUITS AND FISH}

A SPECIALTY.

QUEENSIMARE.

MOODENYLARE

AND NOTIONS.

\section{P. W. ZEIGLER,}

\section{HARDWARE \\ OF ALL KINDS,}

Jewel Ranges and Cook Stoves,

Genuine Round 0ak Stoyes,

Jewel Base Heaters.

Pumps of all Kinds, Duplex and Joker Windmills, Plumbing, Steam and Gas Fitting.

181/2 POYNTZ AVENUE, MANHATTAN, KAN.
Manhattan Steam Laundry

A. S. LEWIS, Manager.

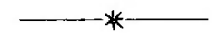

Every class of Laundry Work done to order in a first class and workmanlike manner.

Positively no goods injured by bleaching or by strong acids.

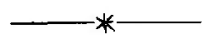

GOODS CALLED FOR AND DELIVERED.

No. 136 S. Second Street. MANHATTAN, KAN.

ESTABLISHED 1859. $\because \div$

G. W. HIGINBOTHAM, PROPRIETOR OF Blue $\times$ Valley $\times$ Mills. DEALER IN ALL KINDS OF GRAIN, LIVE STOCK, HARD and SOFT COAL.

Our Brands of Flour are:

PATENT, FROST KING, GOLDEN RULE, VICTOR, KANSAS BEST.

MANHATTAN, KANSAS. 

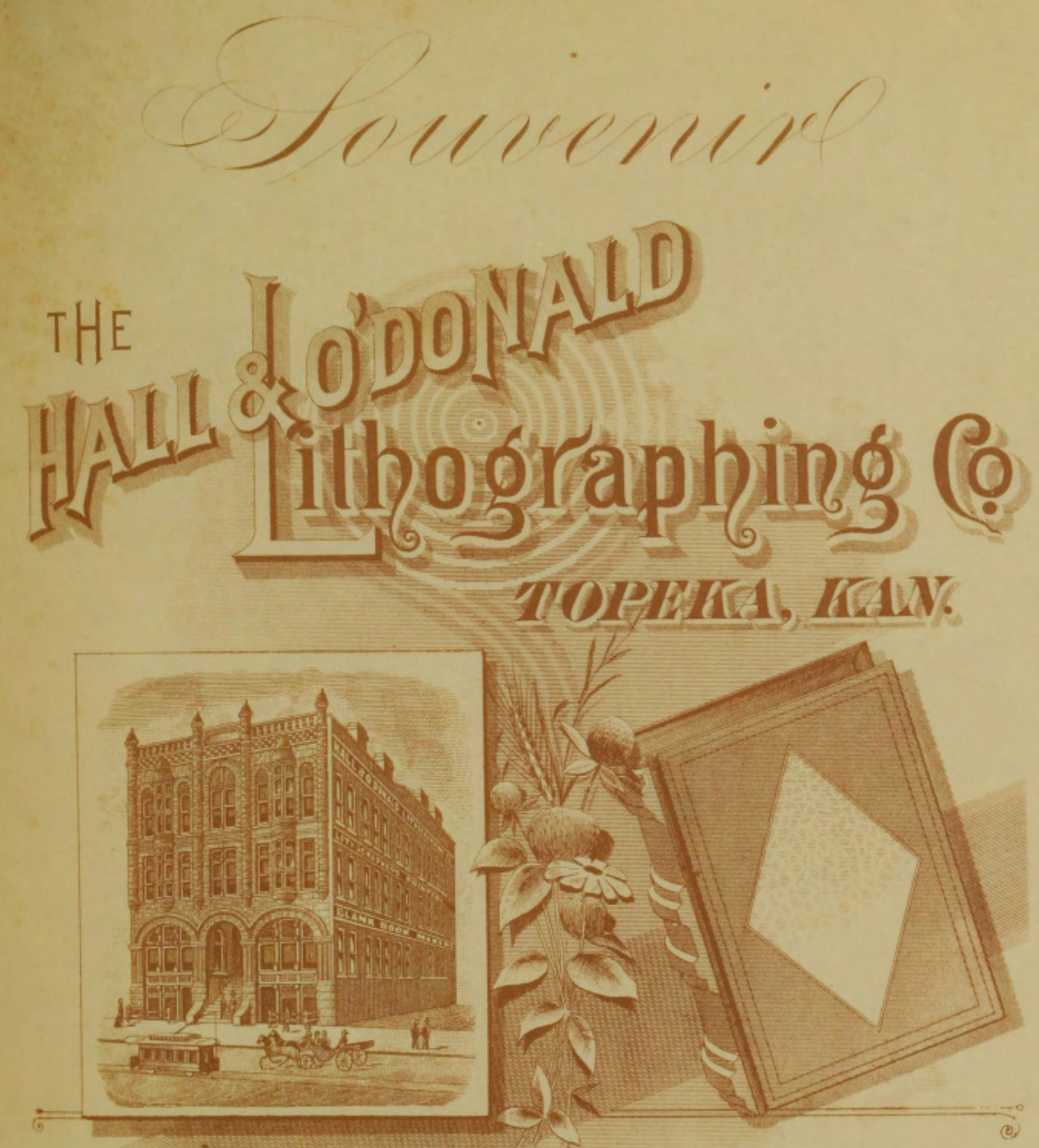

IITIIOGRAPA ERS:

$$
\text { PRINTERS \& STATIONERS: }
$$

MNUFACTUREPS
OF

CELEBRATED

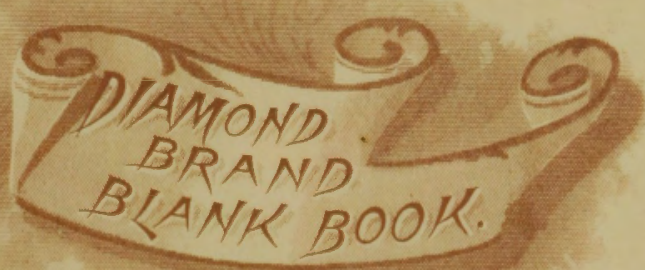

Metallic files and

Vauit Furniture.

Bank and Office Butfitters.

Branch House

(c) alt agke $_{g}$ ity. Stat? 

Pete Hostrup's Barber Shop,

s. Second Street

12 Shaves $\$ 1$, Cash.

6 Bath Tlckets \$1, Cash.

HAIR CUTTING A SPECIALTY.

ALL WORK FIRST CLASS.
BATH ROOMS AND BARBER SHOP.

TOWERS BROS., PROP'S.

2201 Poyntz Avenue.

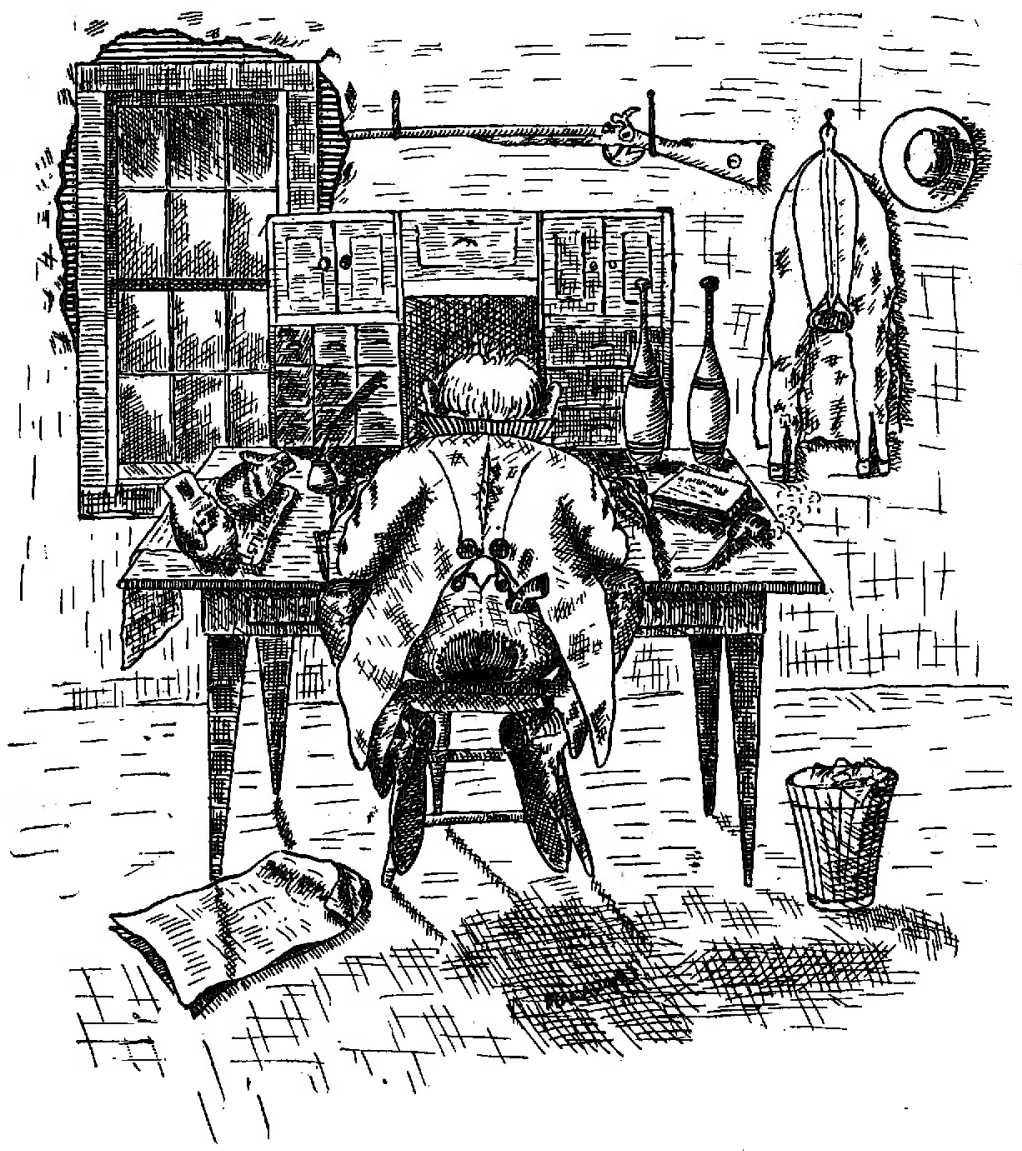

YE SPORTING EDITOR AT HOME, 
$\div$ FIRST

\section{NATIONAL}

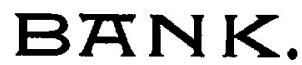

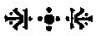

TIANHATTAN, KAN,

하궁

Capital \$100,000.

J. B. Anderson, Prest.

Geo. S. Green, V. Prest.

Geo. S. Murphey, Cashier. John E. Hessin, Attorney.

\section{BALDERSTON'S}

BAKERY

- AND -

RESTAURANT.

A Complete Stoch of Fresh

Groceries • and $•$ Flour

Kept Constantly in Stock.

$$
\text { Fresh }
$$

Bread, Cakes and Pies, EVERY DAY.

\section{F. L. Murdock,}

D. D. S.

DENTIST .

-:-:-

Office over Fox's Book Store.

MTANHTTAN,

$\therefore \quad$ KANSAS. $\div$

\section{J.PICKETT,}

Livery, Feed and Sale STABLE.

Good Rigs, Lively Teams and Fair Prices.

Students' Patronage

Respectfully Solicited.

MANHATTAN, KAN. 


\section{THE E. B. PURCELL MERCANTILE COMPANY,}

INCORPORATED 1887. CAPITAL \$50,000.00. FULL PAID.

Successors to Cash house of E. B. Puroell. Established I 866.

\section{Dealers in EVERYTHING}

ㅍ. B. PUF○卫工工, MANTFAATTANT, PRESIDENT and MANAGER. IXANSAS

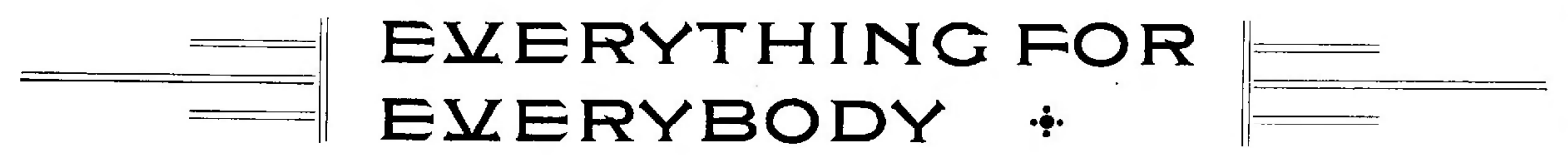

BIGGEST DEPARTMENT HOUSE IN KANSAS.

Quick Delivery to any Part of the City.

Get one of Our CASH Trade Tickets. 


\section{TAYIOR BROS., \\ ... Druø̧ists, \\ MANHATTAN, KANSAS.}

\section{Stlanhattan hepublic,}

DAILY and WEEKLY.

ALL THE LATEST NEWS. ㄱ SUBSCRIBE K

\section{PAINTER AND PAPER HANGER,}

All Work Done with Neatness and Dispatch.

MANHATTAN, KAN

A. S. HOUGHTON \& $\mathrm{CO}_{\text {, }}$ Livery, Feed and Sale Stable,

Opposite Commercial House.

MANHATTAN, KANSAS.

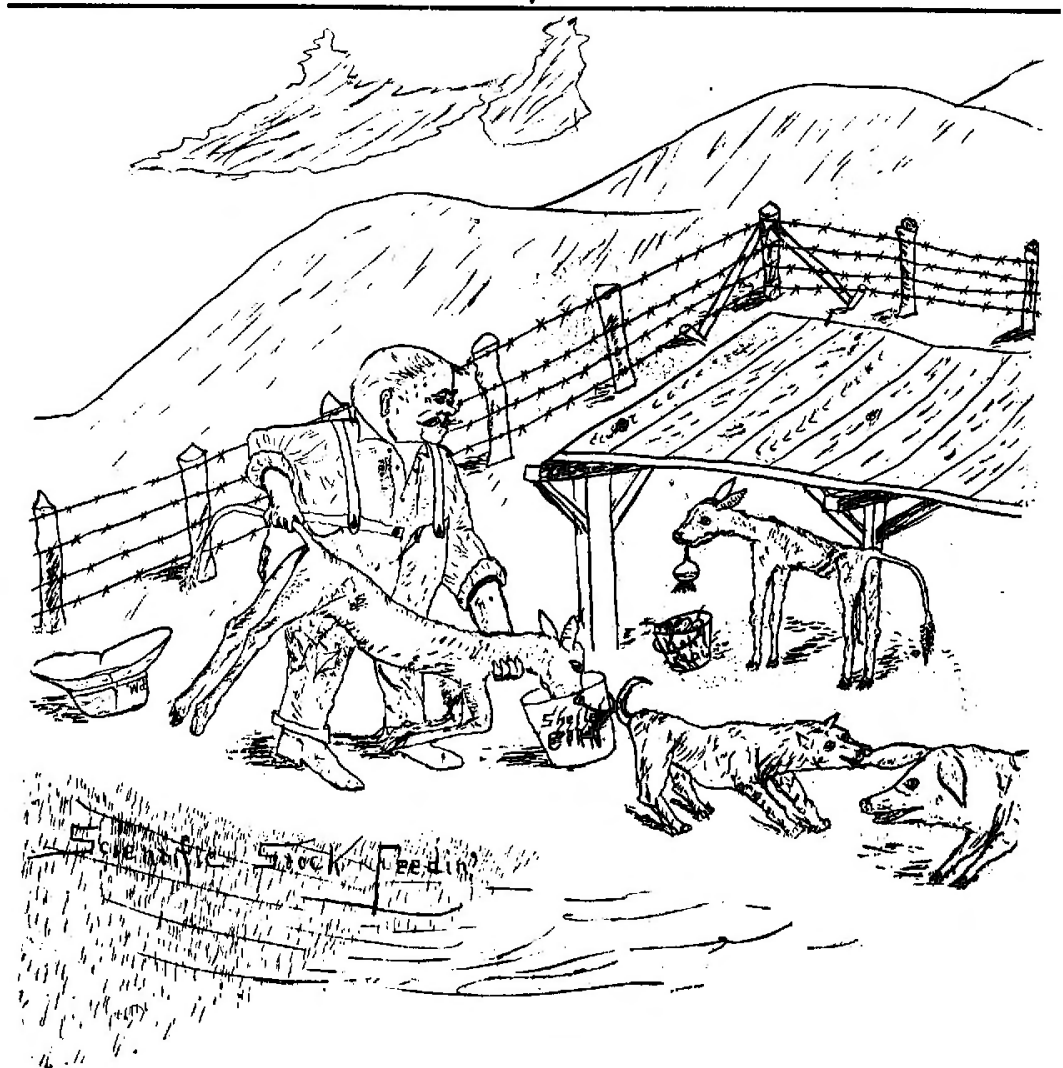

SCIENTIFIC BTOCK HELDIN' 


\section{The Western School Journal}

Is published every month in the year. It discusses questions relating to all grades of school work. It publishes the questions prepared by the Kansas State Board of Education for the examination of county teachers, and the answers to the questions.

In the JOURNAL can a/so be found full reports of all the great educational meetings held in Kansas, and $m$.ch other news pertaining to teachers and schools,

Subscription price $\$ 1.25$; in clubs of five \$1. Send for a sample copy and club ates. Address

WESTERN SOHOOL JOURNAL, Topeka, Kan.

工EW FAYD耳IV, Gunsmith and Machine Repairer, Dealer in Organs, Pianos, Sewing Machines, Guns and Pistols. 221 POYNTZ AVENUE.

R. G. A. ORISF, DENTIST.

321 Poyntz Ave., Manhattan, Ks.

The Preservation of the Natural Teeth a Specialty.

\section{J. LYMAN, M. D.,}

Office in Eames Block. LOCAL SURGEON

Union Pacitic Railroad.

Cilicago, Rock Island \& Pacific Railroad, Atchisnn, Topeka \& Banta Fe Railroad.

Manhattan, Kansas.

\section{STUDENTS WANTED.}

We furnish students with pleasant and profitable employment during vacation. Many young men are earning enough money in a few weeks to heep them in college during the year. Our two new specialties are particularly applicable to work in Kansas. Write for particulars to CENTRAL SCHOOL SUPPLY HOUSE,

F. U. ALBRECHT 176 Fifth Ave., Chicago. Western Manager

J. M. ROOT \& CO., Manhattan Marble Works, Cor. 4th Street and Poyntz Ave.

All kinds of Tombstone and other Marble and Granite work done to order. Special drawings furnished. All are invited to call and examne our work.

G. B. H I M ES, Manufacturer and Dealer in

\section{Harnpess and Saddles.} . . . . .

Hides and Furs Bought and Sold.

\section{R. J. BEACHUM,}

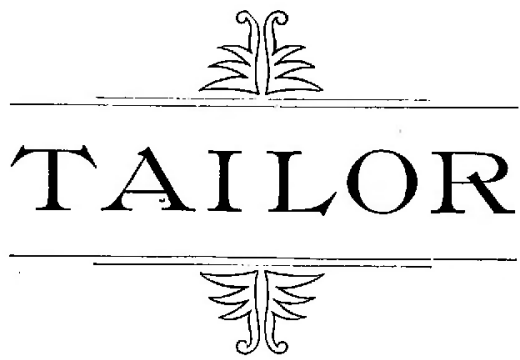

Manhattan, Kansas. 


\section{Hickory Hill Stock Farm}

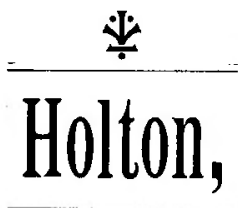

床
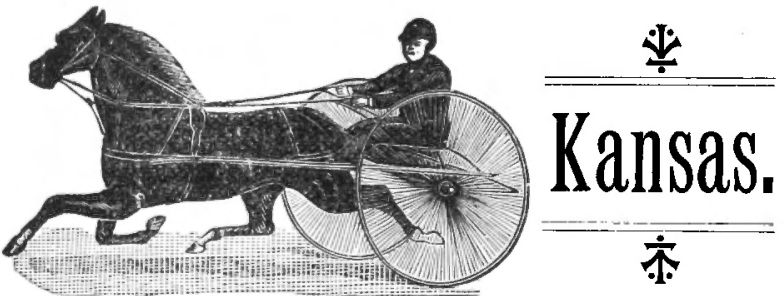

Fashionably Bred Trotting Pacing Horses.

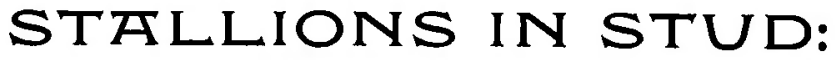

King Spraque, 2:28;, black, 16 hands, 1200 pounds, by Gou. YITy SPraque, sprague, 2:201/2; dam, Molly Whitefoot, dam of Croxie, 2:191/4. Frank Champ, 2:16,4. King Sprague, 2:28, Mulato, four year old, trial 2:26\%:

Savolax, 10788, Bay, 15: hands, 1100 pounds, by Dictator, (sire of Jay Eye See, 2:10); dam by Strathmore, (sire of dam of C. F. Clay, 2:18); grandam by Clark Chief, sire of dam of Phollas, $2: 13^{3}, 4$.

Wilke Brino, Blood bay, 3 years old, 16 hands, 1200 pounds, by Red

Dolph, Bay, 16 hands, 1200 pounds, by Dall Brino; dam by Green's

Otto W., 3 year old, 2:25, pacer, 15:/2 hands, 1080 pounds, by Dall 'Brino; dam, Bessie B, by grandson of Bonnie Scotland.

Dandy O., $\begin{aligned} & 151, \text { hands, } 1000 \text { pounds, by Dall Brino; dam, Mayflower, } \\ & \text { a double grandam of Alexander's Abdallah. }\end{aligned}$

We solicit the patronage of all lovers of a good horse. Visitors welcome and stock shown with pleasure, six days in the week.

Fine drivers, young stoch of both sexes, and mares in foal for sale.

\section{LINSCOTT BROS., HOLTON, KAN.}







- ions

S)

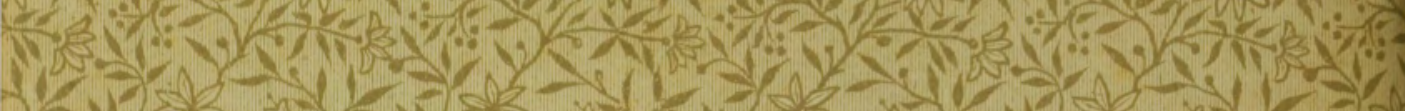

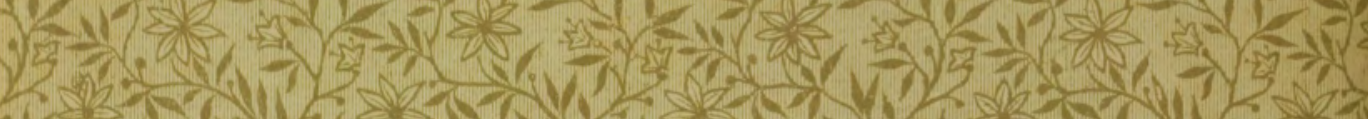

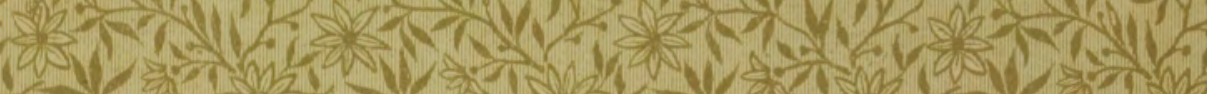

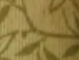

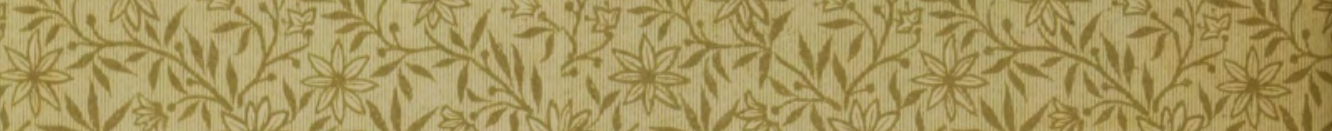

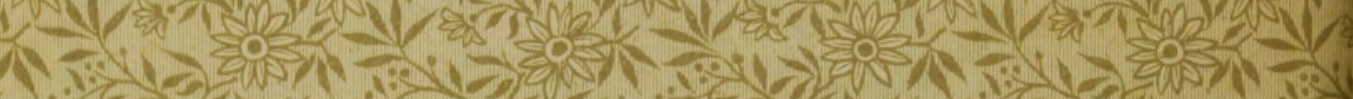

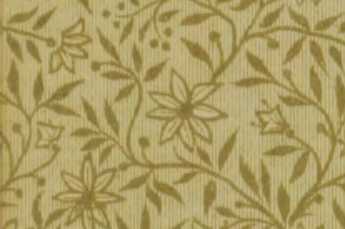

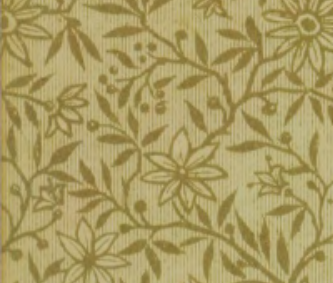

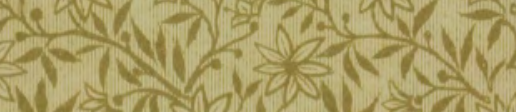

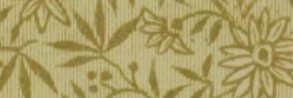

120

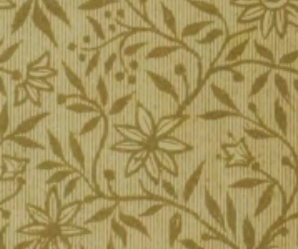
201

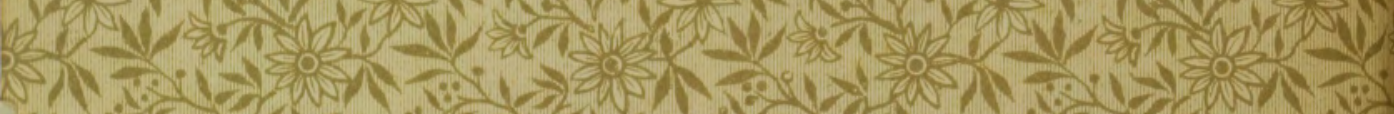

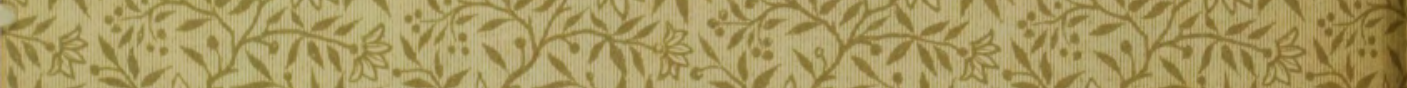

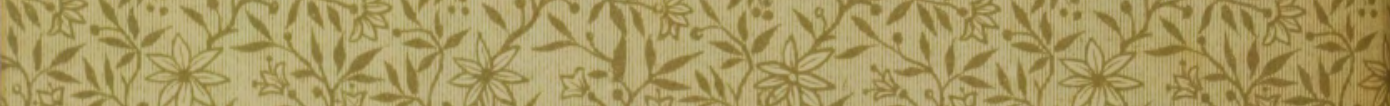

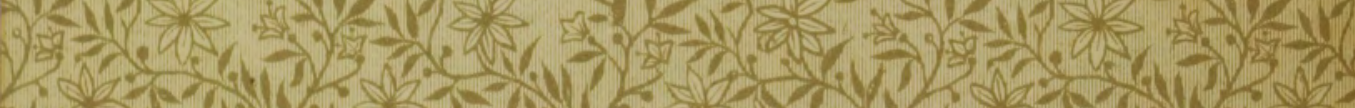

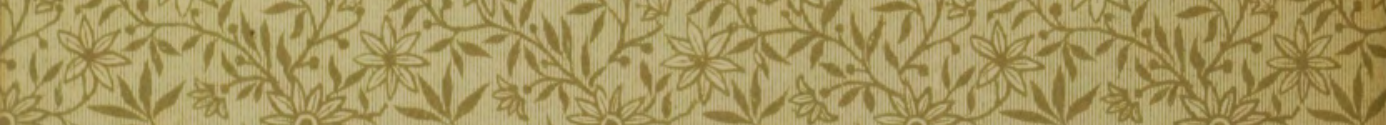

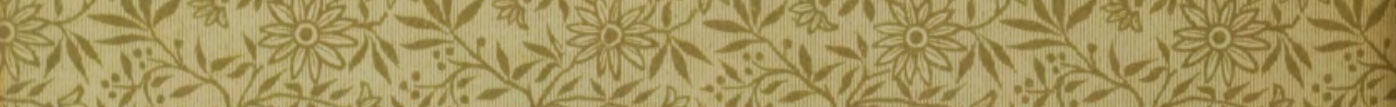

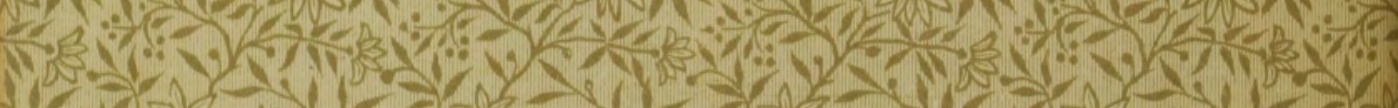

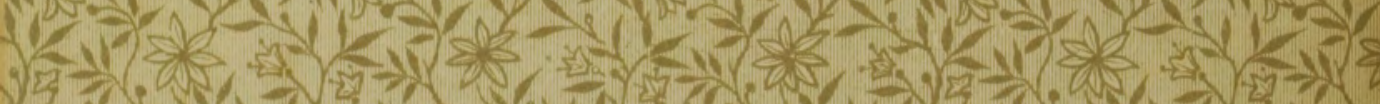

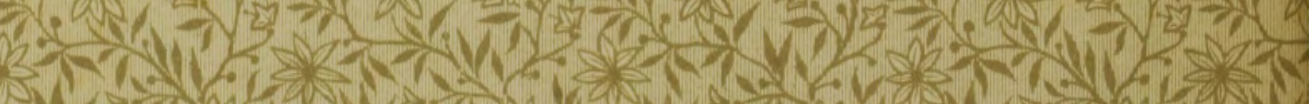

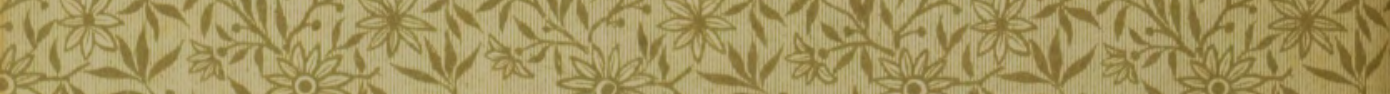
N

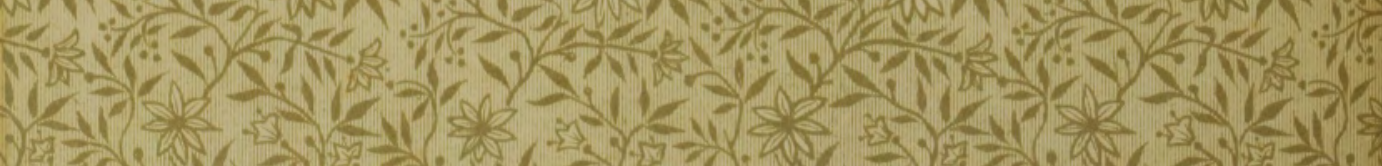




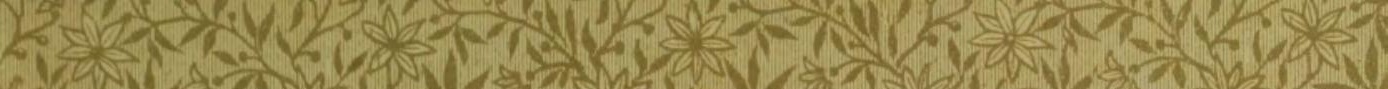
3 (1) 51 (2) (2) D.

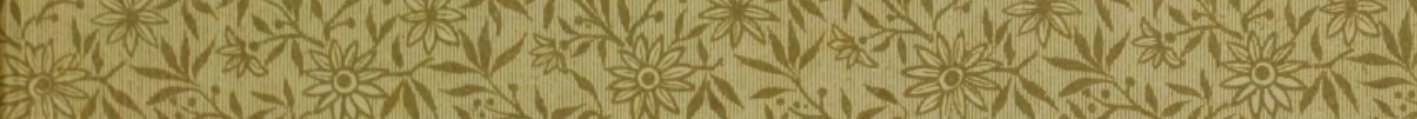

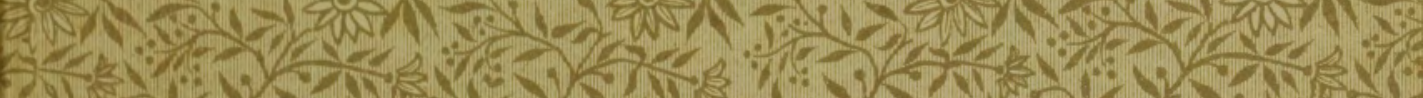
(5)

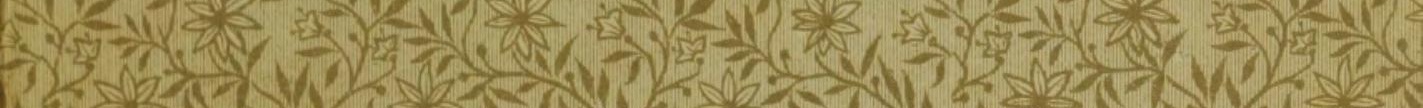

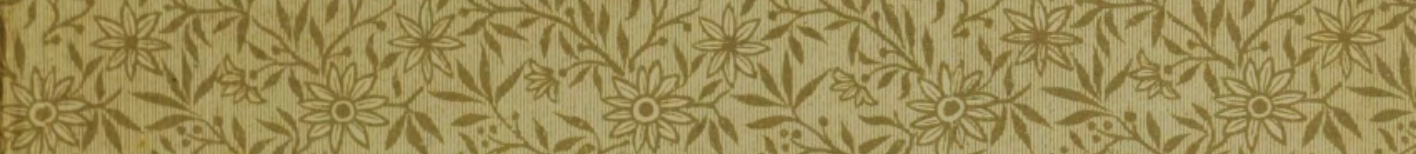

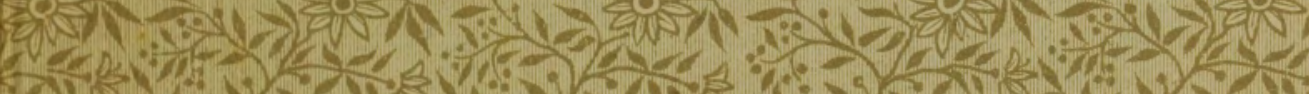
S.

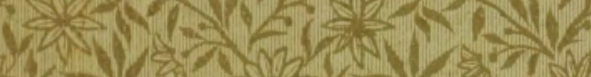

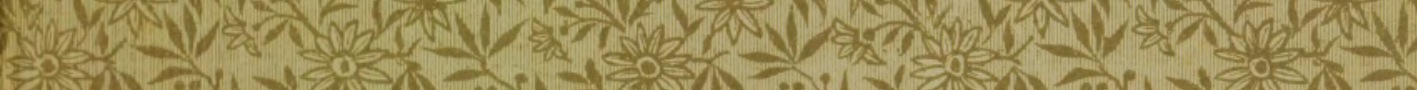
( No 1. I- $1-7$ 2) 2. (25) 1. 1 (2)

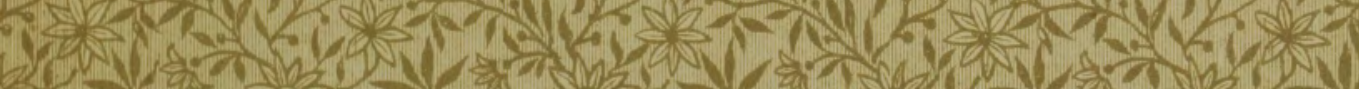
(5) -

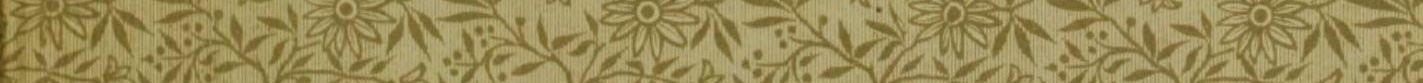

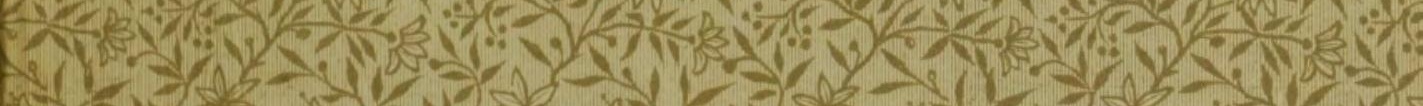
(1)

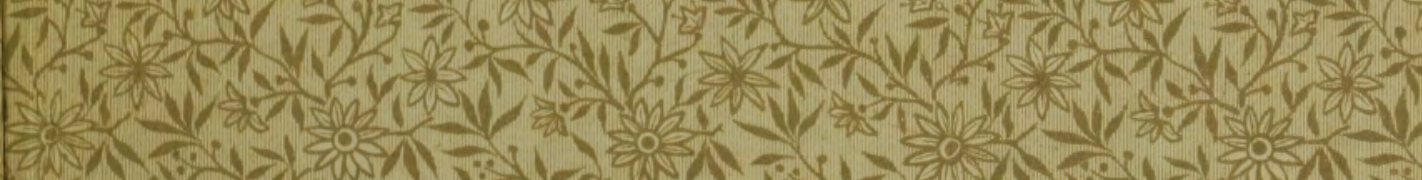
m 


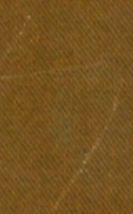

$x^{2}+x^{2}-2=$ 